Flávia Maria Cavallo Pfeil

\title{
Abandono escolar compulsório de meninas: \\ Trabalho reprodutivo e trabalho doméstico na Modernidade/Colonialidade
}

\section{Tese de Doutorado}

Tese apresentada como requisito parcial para obtenção do grau de Doutor pelo Programa de Pós-Graduação em Psicologia (Psicologia Clínica) do Departamento de Psicologia da PUC-Rio.

Orientadora: Profa. Maria Helena Rodrigues Navas Zamora 
Flávia Maria Cavallo Pfeil

\section{Abandono escolar compulsório de meninas: Trabalho reprodutivo e trabalho doméstico na Modernidade/Colonialidade}

Tese apresentada como requisito parcial para obtenção do grau de Doutor pelo Programa de Pós-Graduação em Psicologia (Psicologia Clínica) da PUC-Rio. Aprovada pela Comissão Examinadora.

Profa. Maria Helena Rodrigues Navas Zamora

Orientadora Departamento de Psicologia - PUC-Rio

Profa. Sonia Maria Giacomini Departamento de Ciências Sociais - PUC-Rio

Profa. Ariane Rego de Paiva Departamento de Serviço Social - PUC-Rio

Profa. Giovanna Marafon UERJ

Profa. Claudia Freire Vaz Universidade Estácio de Sá - UNESA

Rio de Janeiro, 30 de março de 2020. 
Todos os direitos reservados. É proibida a reprodução total ou parcial do trabalho sem a autorização da universidade, da autora e da orientadora.

Flávia Maria Cavallo Pfeil

Graduada em Psicologia pela PUC-Rio, em 2010. Atuou no campo de pesquisa da Saúde Pública e Direitos Humanos e publicou em coautoria o livro "Quem tem medo de falar sobre drogas? Saber mais para se proteger", pela Editora FGV (2015). Mestra em Psicologia pela PUC-Rio, em 2013. Atua como psicóloga educacional do quadro efetivo da Prefeitura Municipal de Paraty. É cofundadora do Coletivo Feminista M.A.R.

Ficha Catalográfica

Pfeil, Flávia Maria Cavallo

Abandono escolar compulsório de meninas: trabalho reprodutivo e trabalho doméstico na modernidade/colonialidade / Flávia Maria Cavallo Pfeil; orientadora: Maria Helena Rodrigues Navas Zamora. 2020.

189 f. : il. color. ; $30 \mathrm{~cm}$

Tese (doutorado)-Pontifícia Universidade Católica do Rio de Janeiro, Departamento de Psicologia, 2020.

Inclui bibliografia

1. Psicologia - Teses. 2. Colonialidade.3. Trabalho reprodutivo. 4. Trabalho doméstico.5.Racismo. 6. Abandono escolar.I. Zamora, Maria Helena Rodrigues Navas. II. Pontifícia Universidade Católica do Rio de Janeiro. Departamento de Psicologia. III. Título. 
Às minhas avós Yonne e Elenira (in memorian) 


\section{Agradecimentos}

À minha orientadora, professora e amiga querida Maria Helena Zamora pelas trocas e ensinamentos sempre carregados de tanto afeto e comprometimento, há tanto tempo.

À CAPES, pelo apoio para a realização da pesquisa. O presente trabalho foi realizado com apoio da Coordenação de Aperfeiçoamento de Pessoal de Nível Superior - Brasil (CAPES) - Código de Financiamento 001.

À PUC-Rio, pelos auxílios concedidos e sem os quais esse trabalho não poderia ter sido realizado.

Ao meu filho, Martín, que há cinco anos vem construindo comigo essa relação de afeto profundo e revolucionário, de uma maneira tão nossa, regada de palavras, gestos e sonhos de liberdade.Como você diz, "somos uma grande dupla"!

À minha mãe, Eliane, que de todos os jeitos possíveis sempre esteve ao meu lado, me ensinando muito e me ajudando a ver a vida com esperança.

À minha dinda, Maria Cristina, e sua presença tão amorosa, solidária e respeitosa ao longo de toda a minha vida.

Ao meu irmão André, pela amizade e companheirismo que construímos juntos há tanto tempo e com tanto comprometimento e amor. E a querida Bibi, pelas preciosas trocas intelectuais e afetivas, cuidadosas e firmes.

Ao meu irmão e compadre Luiz que, mesmo de longe, nunca deixou de se fazer presente e contribuir amorosamente com a minha caminhada. E a querida Mônica e seu cuidado sempre tão carinhoso comigo.

À Simone, grande amiga, uma das mulheres mais incríveis que eu conheço e que generosa e amorosamente vem compartilhando comigo afetos, ensinamentos e sonhos, desde que nos conhecemos para formar um grupo de estudos muito especial, em 2009.

À amada amiga e eterna professora Gil, por tanto afeto e apoio desde que nos encontramos nesta vida. Pelo incentivo e pela confiança que me concede e que tanto me emociona. Por me ensinar muito sobre educar para a autonomia.

À Kenia, esse presente que o doutorado me deu. Não é que eu morri, é que estamos muito vivas uma na outra e isso é emocionante!

Às minhas amigas e companheiras do Coletivo Feminista Maria Angélica Ribeiro, pelos ensinamentos cotidianos, pela força que somos juntas, por serem alimento e sustento para esta pesquisa e para minha vida. Thalita, Maira Campos, Carol, Maira Norton, Antonia, Lila, Indá, Corina, Olímpia, Laura, Adele, 
Januária, vocês são inspiradoras e eu sou grata a todas e a cada uma de vocês. Muito.

Às/aos minhas/os preciosas/os companheiras/osdo Porta da Lembrança, este grupo que através de muito comprometimento, trabalho e alegria vem construindo tanto, ensinando tanto, sendo tanto. Vocês moram em um lugar bem lindo e especial aqui dentro, queridas/os. Obrigada, obrigada, obrigada!!

À Rita, Janaína, Eliane, Nina, Roberta, Iaci, Adriana, Laura, Rosana... e todas as educadoras/es que dentro e fora da escola sustentam práticas insurgentes, comprometidas com a educação para a liberdade. Que honra trabalhar e aprender cotidianamente com mulheres criativas, comprometidas e firmes na luta como vocês.

Ao coletivo Articula Preta, pelas práticas que tanto ensinam e contribuem para um olhar mais crítico sobre as posições que ocupamos nesse mundo.

A todas/os as/os minhas/meus familiares que, como puderam, sempre me apoiaram com carinho.

Às amigas e aos amigos que, sempre afetuosas/os e disponíveis, estiveram por perto, cada uma/umà sua maneira, especialmente nestes quatro revolucionários últimos anos, mas também antes.

Às estudantes e aos estudantes das escolas onde trabalho e que são sempre grandes mestras e mestres. Sem essa troca não há educação.

A todas as meninas e mulheres, cujas vozes impregnam esse texto e transformam a cada encontro meu olhar para o mundo. Que nada nos limite, nos defina ou nos sujeite. Até que todas sejamos livres. Vamos juntas! 


\section{Resumo}

Pfeil, Flávia Maria Cavallo; Zamora, Maria Helena (Orientadora). Abandono escolar compulsório de meninas: Trabalho reprodutivo e trabalho doméstico na Modernidade/Colonialidade. Rio de Janeiro, 2020, 189p. Tese de Doutorado- Departamento de Psicologia, Pontifícia Universidade Católica do Rio de Janeiro.

Esta pesquisa tem como objetivo analisar as especificidades do dito "abandono escolar" de meninas da rede pública de ensino. A partir do diálogo com autoras/es feministas, descoloniais e antirracistas, buscamos deflagrar as persistências da lógica colonial, essencialmente racista e patriarcal, na modernidade/colonialidade e seus efeitos na vida de meninas e mulheres das classes subalternizadas. Analisamos que a produção do fracasso e/ou do abandono escolar de meninas, assim como o de meninos, na maioria das vezes tem relação com as desigualdades econômicas e raciais que estruturam nossa sociedade. No entanto, no caso das meninas, por terem historicamente, pela ordem patriarcal, suas capacidades reprodutivas e sexuais como alvo de controle e exploração, seu afastamento da escola apresenta razões peculiares. Elas se relacionam com divisão sexual do trabalho, que coloca o trabalho reprodutivo e o trabalho doméstico como funções naturais e prioritárias do denominado "sexo feminino", posicionando outras atividades em lugar de menor importância. Operando na colonialidade, a educação também pode desempenhar um papel importante neste processo. Ao (re)produzir discursos e práticas que reforçam os papéis sexuais, perpetua a ideia de que a escolarização é secundária para as meninas, contribuindo para o abandono escolar.

\section{Palavras-chave:}

Colonialidade; trabalho reprodutivo; trabalho doméstico; racismo; abandono escolar. 


\section{Abstract}

Pfeil, Flávia Maria Cavallo; Zamora, Maria Helena (Advisor). Girl's compulsory school abandonment: Reproductive work and domestic work in Modernity/Coloniality. Rio de Janeiro, 2020, 189p. Doctoral Thesis- Departamento de Psicologia, Pontifícia Universidade Católica do Rio de Janeiro.

This research aims to analyze the specificities of the so-called "school abandonment" of girls from the public school system. Based on the dialogue with feminist, decolonial and anti-racist authors, we seek to trigger the persistence of colonial logic, essentially racist and patriarchal, in modernity/coloniality and its effects on the girls and women from subalternized classes lives. We analyze that girls "failure" and / or "abandonment", as well as boys', are most often the product of the economic and racial inequality that structures our society. However, in the case of girls, who historically have, in the patriarchal order, their reproductive and sexual capacities as a target for control and exploitation, their withdrawal from school has peculiar reasons. They are related to the sexual division of labor, which places reproductive work and domestic work as natural and priority functions of the so-called "female sex", placing any other activity in a less important place. Operating in coloniality, education can also have an important role in this process. By (re)producing discourses and practices that reinforce sexual roles, it perpetuates the idea that schooling is secondary for girls, contributing to school abandonment.

\section{Keywords:}

Coloniality; reproductive work; domestic work; racism;school abandonment. 


\section{Sumário}

1. Introdução 11

2. Modernidade/Colonialidade, relações de poder e saber

22

2.1. "Coração Americano, acordei de um sonho estranho":

a construção colonial do poder e do saber modernos

22

2.2. Despatriarcalizar para descolonizar: perspectivas feministas decoloniais das relações de poder e saber modernas/coloniais

3. Sistema de gênero moderno/colonial, subalternização das mulheres e lutas feministas

3.1. "Caça as bruxas" e patriarcado moderno/colonial

3.2. Sistema de Gênero Moderno/Colonial e radicalização da condição subalterna das mulheres colonizadas

3.3. Dispositivos de subordinação das mulheres na modernidade/colonialidade

3.4. Imbricações e produções de hierarquias na classe de mulheres

3.5. O sentido de "ser branca": a branquitude em questão

4.1. Fundamentos da escola pública no Brasil e Colonialidade: caminhos para o fracasso

4.2. Desigualdade Racial, Psicologia escolar e individualização do fracasso

4.3. Impactos do racismo na produção de fracasso

e abandono escolar 
5.1. Brasil: um país perigoso para mulheres

5.2. Divisão sexual do trabalho na modernidade/colonialidade e abandono escolar compulsório de meninas

6. Considerações finais

170

7. Referências bibliográficas 


\section{INTRODUÇÃO}

O que torna tão incomparável e tão irrecuperável a primeiríssima visão de uma aldeia, de uma cidade na paisagem, é que nela a distância vibra na mais rigorosa ligação com a proximidade. O hábito ainda não fez sua obra. Uma vez que começamos a nos orientar, a paisagem de um só golpe desapareceu como a fachada de uma casa quando entramos. Ainda não adquiriu uma preponderância através da investigação constante, transformada em hábito. Uma vez que começamos a nos orientar no local, aquela imagem primeira não pode nunca restabelecer-se (BENJAMIN, 1987, p. 43).

Cheguei a Paraty com uma expectativa enorme. Sempre viajara para Trindade, distrito da cidade, nas férias. De 2001 a 2009, ela foi o meu lugar de refúgio. Durante esse período, pelo menos uma vez ao ano, acampava por alguns dias com familiares, e depois com amigos, na Praia do Meio.

Era tão bonita a Trindade! Chegava-se ao vilarejo por uma estrada sinuosa, de asfalto surrado, beirando um grande penhasco. Estrada que levava até a rua principal do povoado. Estreita, a rua era margeada por poucas construções - casas, pousadas e alguns restaurantes. Além da beleza natural, me encantava o ritmo daquele lugar. Um ritmo que me levava para uma dimensão onde tudo era belo, alegre e calmo.

Foi motivada por essas memórias afetivas que decidi prestar o concurso público para psicóloga educacional desse município. Quando cheguei à cidade para fazer a prova, já fazia quatro anos que não a visitava. Ela estava diferente, ganhara um tom "moderno". Até a bucólica praça em frente à Igreja da Matriz, situada no seu famoso centro histórico, havia sido reformada e agora exibia contornos "modernosos", destoando do seu entorno.

Outra coisa que me chamou atenção, também no centro histórico, foi o grande número de crianças indígenas que perambulavam pelas ruas pedregosas, sozinhas ou apenas na companhia de seus pares. Enquanto seus responsáveis - em geral mulheres - expunham e vendiam para os turistas os utensílios e enfeites por eles produzidos, em panos estendidos no chão da Rua do Comércio (principal rua do centro), as pequenas e pequenos passavam o dia e a noite cruzando os arredores. Descalços e com as roupas surradas, pediam trocados ou comida para as pessoas que estavam sentadas às mesas externas dos bares e restaurantes. Outros se reuniam e cantavam canções em seu idioma para os turistas caminhantes, em troca de algum dinheiro. 
A situação das crianças me causou, de imediato, indignação. Como não se indignar ao ver crianças, ainda muito pequenas (algumas não aparentavam ter mais de quatro anos de idade), em tamanha exposição? Foi principalmente a cena das pequenas meninas e meninos cantando nas portas dos bares e comércios, sendo fotografados e aplaudidos pelos visitantes, que marcou minha memória de um sabor amargo. Não compreendia que tipo de afeto alegre aquela cena poderia produzir. O que era digno de ser aplaudido ali?

Não me aprofundei na reflexão naquele momento, continuando minha caminhada turística em direção ao cais pesqueiro, rumo à costa. Se havia uma coisa que eu não me cansava de fazer em Paraty era contemplar aquelas deslumbrantes montanhas multicoloridas, alinhavadas por rios doces a desaguar num imenso mar salgado e verde.

Um mês depois, soube que havia sido aprovada no concurso. Em três meses assumi o cargo e passei a residir em Paraty. Saia da condição de visitante para a de moradora e trabalhadora do município. Movimento que produziria transformações significativas na minha relação ética e estética com aquele cenário, que aos poucos ia se tornando um espaço ${ }^{1}$ (SANTOS, 1978). Sua imagem até então fixada apenas em beleza e alegria, se deslocava, ganhando movimentos difusos e também conflituosos.

Benjamin (1987) diz que quando nos habituamos a uma paisagem, a um local, necessariamente o recriamos. Ao me habituar a Paraty, fui levada a reconstruir minha visão e meus afetos sobre ela e, assim, transformá-la para mim.

A princípio vivi uma espécie de luto. Luto por minhas memórias de outrora que, impregnadas pela nova experiência com a cidade, eram necessariamente ressignificadas. Paraty ia abandonando gradualmente o lugar idealizado em que eu a guardava. O lugar de refúgio, que de alguma maneira conservava uma ingenuidade em meu olhar, dolorosa de ser abandonada.

\footnotetext{
1،[...] O espaço por suas características e por seu funcionamento, pelo que ele oferece a alguns e recusa a outros, pela seleção de localização feita entre as atividades e entre os homens, é o resultado de uma práxis coletiva que reproduz as relações sociais, [...] o espaço evolui pelo movimento da sociedade total" (SANTOS, 1978, p. 171).
} 
Nessa rua de mão única que é a experiência, era preciso seguir adiante. Não no sentido de um progresso automatizado, mas de embarcar em um fluxo contínuo que nos impulsiona a buscar novas direções, novos sentidos - onde outras belezas e dissabores se revelam.

Das grandes belezas que se revelaram a partir da abertura a uma nova experiência em/com Paraty, uma das mais significativas e revolucionárias foi (re)conhecer a multiplicidade cultural que constitui o território e o povo brasileiro. Apesar de, teoricamente, saber que o Brasil é um país bastante múltiplo culturalmente, nada do que aprendi nos livros didáticos, na escola ou mesmo na universidade, fazia jus à experiência de conviver e trabalhar com essa multiplicidade cotidianamente.

Apesar de pequena, a multiplicidade cultural existente na cidade de Paraty é grande, sua população inclui povos tradicionais, como os caiçaras, quilombolas, indígenas... Povos do campo e da floresta. Em pouco tempo, começava a perceber que a existência desses povos no território paratiense se constitui a partir de resistências contínuas aos processos de objetificação e marginalização que incidem sobre eles. Processos produzidos e reproduzidos com base no silenciamento sistemático que esses grupos vêm sofrendo ao longo da história. Dissabores começavam a se desvelar.

Meu reencontro com as crianças indígenas nas ruas do centro histórico foi marcado por dissabores. Eram guaranis, descobri. Continuavam a caminhar sozinhas ou em grupos pelas ruas de pedras, cantando canções em troca de algum dinheiro ou comida. Suas mães também seguiam por lá, nas beiradas das ruas, vendendo cestarias e bijuterias por elas produzidas e resistindo às constantes intervenções da guarda municipal para impedir sua presença ali, sem oferecer alternativas dignas, garantir direitos básicos. Aquele gosto amargo produzido pelo primeiro encontro se somava a uma textura viscosa, muito difícil de ser tragada.

A paisagem do cais continuava bonita e eu ainda gostava de admirá-la. Mas seu sentido havia mudado. Não se tratava mais de uma tela plástica e estática, emoldurada pelos olhos ascéticos e assépticos que costumavam a contemplar em outro tempo. No novo corpo que eu começava a constituir naquela cidade, ver era buscar sentido. 
Mirava do cais e avistava casas, mansões e casebres cravados nas montanhas e também a beira-mar, em um arranjo ético-estético controverso. Quem residia ali? Que relações atravessavam aquelas construções e vidas? O que a singularidade dessas relações revelava sobre a história coletiva daquele espaço?

Paraty não apenas mudou para mim, ela mudou a mim. Meu olhar para o mundo foi, e vem sendo ainda, imensamente afetado por essa outra experiência com a cidade. Neste processo, em muitos momentos me vi como o personagem de Kafka (2011), GregorSamsa, em “A metamorfose”, quando, ao acordar na couraça de uma barata, experimentava suas muitas pernas que "lamentavelmente finas em comparação com o volume do resto de seu corpo, vibravam desamparadas ante seus olhos" (p. 13).

As perguntas não paravam de surgir. Constituíam e eram constituídas nas diversas vivências e convivências com o vivo território paratiense. Mas era nos espaços escolares onde vozes retumbavam em ritmo atordoador. Vozes que não vinham apenas de cordas vocais, mas de corpos inteiros, de seus movimentos e encontros com outros corpos, com construções, com teorias, com normas, com instituições, com coletivos.

Chamavam atenção especialmente às vozes que na escola endereçam à psicologia intervenções normatizadoras àqueles "corpos-vidas" (ARROYO, $2012)^{2}$ estudantis que desafiavam as regras e frustravam as expectativas impostas pelo sistema educacional instituído. "Estudantes excessivamente agressivos!", apontavam. Violentos no modo de agir, de se relacionar com outros colegas e com funcionários da escola, com os conteúdos didáticos, com o espaço, com o próprio corpo. Queixas que vinham acompanhadas majoritariamente de discursos que localizavam nos próprios estudantes e/ou em suas famílias e comunidades as origens principais de tal comportamento.

As palavras de Bertold Brecht (1898-1956) ecoavam: "Do rio que tudo arrasta, diz-se que é violento. Mas ninguém chama violentas às margens que o comprimem". Nas experiências na escola concluo que o espaço escolar é, de fato,

\footnotetext{
${ }^{2}$ Ao se referir a "corpos-vida" Arroyo marca a necessidade de incluir a dimensão corpórea tanto das intervenções normatizadoras quanto das formas de resistência construídas pelos que as recusam.
} 
permeado por violências. Mas viriam estas violências exclusiva e naturalmente dos estudantes e/ou de seus núcleos familiares e comunitários? E as margens, de que são compostas? Que compressões impõem? Quem as conduz?

Passei a me debruçar sobre as margens. Neste movimento tropecei em mim mesma e caí. No chão, eu e a margem. Era eu a margem? As pernas finas da barata kafkaniana vibravam desamparadas mais uma vez.

"As margens estão largas demais! Precisamos de respostas que justifiquem seus estreitamentos ou perderemos o controle!", gritavam as vozes ocultas dos encaminhamentos para triagem da psicologia escolar.

$\mathrm{Na}$ tarefa de conter os "desvios" dos estudantes, a psicologia escolar aparece como ferramenta fundamental. Munida de métodos supostamente capazes de avaliar características intrínsecas aos indivíduos, a psicóloga é chamada a produzir materiais científicos que justifiquem estratégias institucionais de normatização. Nesta perspectiva, não somos a margem em si e sim parte de sua composição. Mas com o que compactuamos quando aceitamos este lugar? Caberia de fato à psicologia o papel de conter desvios? Que posição ético-política afirmamos quando colocamos o saber psicológico a serviço de práticas de controle?

Tais questionamentos passaram a, cada vez mais, permear e deslocar meus pensamentos e minhas práticas. Eu me sentia a deriva em um mar de perguntas. A experiência transbordava. O mar se agitava. Em meio às ondas ia me encontrando com meu corpo-mulher-trabalhadora-pesquisadora, que chacoalhava em alto mar, abrindo fissuras. Interrogações encharcavam as fendas abertas, instalando dolorosas incertezas. De repente, já não era mais meu corpo, inteiro, neutro e seguro, tentando desvendar o mar. Era eu com o mar. Éramos nós transbordando. Éramos nós em questão.

Em meio a todo esse processo, meu encontro com o movimento político feminista se deu como uma corrente marítima de fluxo intenso que aos poucos foi dando rumos aos meus questionamentos e angústias. Esse envolvimento se iniciou com a minha aproximação com as manifestações de mulheres da cidade, especialmente após o feminicídio de Gisele Alves, skatista de 33 anos que foi 
brutalmente estuprada e assassinada no Centro Histórico de Paraty, no dia 30 de dezembro de 2015. Ele se aprofundou com a criação do Fórum de Mulheres de Paraty e os importantes debates promovidos neste grupo, especialmente em relação às articulação entre as opressões de classe, raça e sexo, e, posteriormente, com a fundação do Coletivo Feminista Maria Angélica Ribeiro (MAR) ${ }^{3}$.

A fundação do MAR e os desdobramentos dos estudos e ações realizadas através dele, marcaram uma posição política que refletiu intensamente na minha vida e na minha prática profissional em particular. Neste âmbito, o reflexo se deu tanto no modo como passei a analisar as demandas trazidas pela escola - e, consequentemente, nas minhas propostas de ação - quanto no modo como passei a ser vista por meus colegas de trabalho e também pelas/os estudantes. Não demorou muito até que eu percebesse que assumir a perspectiva crítica feminista publicamente me trouxe obstáculos e embates, mas, ao mesmo tempo, aberturas e a possibilidade de identificar mais nitidamente aliadas/os. Percebia cada vez mais que marcar um posicionamento político é fundamental para que possamos criar a rede necessária para sustentar nossas lutas.

Uma das demonstrações disso aconteceu alguns meses depois da fundação do nosso coletivo, quando recebi de uma professora da modalidade de ensino Educação de Jovens e Adultos (EJA) o pedido de que realizasse alguma ação com as estudantes mulheres sobre o tema da violência doméstica. A professora me procurou diretamente, não somente por eu ser psicóloga da escola, mas por me reconhecer como alguém que tinha posicionamento declarado de combate às violências machistas.

Segundo a professora, durante suas aulas, algumas estudantes relatavam sofrer violência doméstica. Outras traziam as marcas das violências em seus corpos. Conversamos bastante e depois levei a demanda da professora para a equipe diretiva da escola, apresentando uma proposta de ação, que incluía além do acolhimento individual das estudantes que assim desejassem, uma atividade

\footnotetext{
${ }^{3}$ Este coletivo reúne algumas destas mulheres que compunham o fórum, ligadas à educação, de diferentes idades, a maioria mães, realizando ações majoritariamente voltadas a educação.
} 
coletiva. Esta consistia em construir, em parceria com o Coletivo MAR, rodas de conversa mensais com as estudantes, abertas também às professoras interessadas. O objetivo era construirmos juntas, a partir de uma perspectiva feminista, um espaço seguro de reflexão e ação acerca das diversas questões que atravessam as vidas das mulheres, especialmente no que diz respeito à vida escolar e profissional.

Os depoimentos das estudantes que participaram do projeto revelaram que a maior parte delas abandonou a escola na idade esperada por razões atreladas ao sexismo. Em especial, os relatos traziam experiências de casamento infantil, maternidade e trabalho doméstico. Outra questão importante pontuada por todas foi que no momento em que deixaram de frequentar a escola, nenhuma delas foi procurada por qualquer membro da equipe escolar interessado em saber o que havia acontecido. Ou seja, deixaram a escola silenciadas e anônimas.

$\mathrm{Na}$ época em que esse projeto foi desenvolvido, a maior parte da minha carga horária de trabalho era desempenhada no atendimento a estudantes do segundo segmento do ensino fundamental regular, na faixa etária de 11 a aproximadamente 16 anos. Os relatos das estudantes do EJA fizeram com que eu passasse a observar com mais atenção as especificidades das trajetórias escolares das estudantes dessa modalidade, em especial, das que apresentavam dificuldades de permanência na escola.

Na medida em que lançava um olhar mais atento para essas trajetórias, ia identificando como a ordem patriarcal incide sobre as vidas das estudantes como uma força que as empurra para fora da escola. Mesmo quando não levam ao abandono, impõe dificuldades específicas em seus processos de escolarização.

Em geral, as estudantes do sexo feminino que acompanhei tinham passado ou passavam por uma ou mais destas experiências: violências sexistas concretas e simbólicas, relacionamentos abusivos, casamento infantil, maternidade precoce e compulsória, trabalho doméstico, exploração, abusos e assédios sexuais.

A partir dessa constatação, passei a olhar para todas as mulheres a minha volta, inclusive para mim mesma, e perceber que a trajetória de vida de todas nós, em maior ou menor grau, é marcada por experiências desse tipo. A ordem 
patriarcal e a hierarquização sexual por ela imposta incide e produz sobre nossos corpos-vidas necessariamente violentando, desde que nascemos.

Ao mesmo tempo, notava que existiam diferenças significativas no modo como tais experiências eram vividas e percebidas. Quanto mais aprofundava as análises, leituras e, especialmente, quanto mais atentamente escutava estudantes e companheiras, percebia que a dominação patriarcal sobre os corpos femininos não pode ser analisada sem levar em conta sua articulação com os outros sistemas de dominação estruturantes do modelo de sociedade vigente. Assim, para compreendermos as especificidades das dificuldades enfrentadas por meninas e mulheres ao longo da vida e, particularmente, no processo de escolarização, é necessário considerar não apenas a ordem patriarcal e a opressão sexista por ela imposta, mas sua articulação com os sistemas de dominação de raça e classe e seus efeitos de poder.

O psicólogo Ignacio Martin-Baró (1996), aponta que, do ponto de vista do que denominou Psicologia Política, o psicólogo deve definir seu trabalho a partir do profundo conhecimento das condições concretas da população a que deve atender. Para ele, quando adotamos definições genéricas advindas de outros lugares, instala-se uma espécie de miopia que não nos permite ver com clareza as especificidades sociais e culturais de cada realidade.

É dessa perspectiva que surge esta pesquisa, que tem como objetivo analisar as especificidades do dito "abandono escolar" de meninas da rede pública de ensino - que majoritariamente pertencem às classes raciais e econômicas, criadas e subalternizadas pelo sistema capitalista moderno. Na contramão de uma abordagem individualizante, buscamos analisar as linhas de força históricas e sociais que atravessam e constituem o processo de afastamento das estudantes da escola.

Para desenvolver nosso estudo, partimos de uma análise crítica do processo de construção do sistema capitalista moderno e das relações de poder e saber por ele instituídas. Em diálogo com pensadoras e pensadores dos estudos denominados decoloniais, no capítulo 2 , desenvolveremos a perspectiva de que a modernidade é um processo profundamente ligado à experiência colonial e que, portanto, permanece operando a partir das mesmas estruturas de poder fundantes 
desta experiência: o sexismo, o racismo e o classismo (CURIEL, 2009; QUIJANO, 1997; MIGNOLO, 2003, LUGONES, 2008).

Para explicar a continuidade das formas coloniais de dominação mesmo após o fim das administrações coloniais, trazemos o conceito de colonialidade, formulado pelo sociólogo peruano Aníbal Quijano (1992). A colonialidade é definida como uma prática que ultrapassa as particularidades do colonialismo histórico, não se extinguindo com a independência ou descolonização, cuja matriz de poder tem a raça, o racismo e a racialização como elementos centrais, constitutivos e fundantes das relações de dominação.

O conceito de colonialidade é aprofundado por outros/as pensadores/as latino-americanos/as, como Walter Mignolo, Edgardo Lander, Catherine Walsh, Nelson Maldonado Torres e Ramón Grosfoguel com os quais também dialogamos. Estes autores desenvolvem o pensamento de que no processo de constituição da modernidade se engendram três facetas articuladas da colonialidade: a colonialidade do poder, a colonialidade do saber e a colonialidade do ser. De acordo com eles, a colonialidade de poder estabelece e fixa uma hierarquia racializada, onde brancos (europeus) ocupam o topo como sujeitos de poder, conhecimento e humanidade, seguidos por "mestiços", "índios" e "negros" tidos como identidades comuns e negativas.

Mas são as feministas decoloniais que, trazendo a perspectiva das mulheres pertencentes aos grupos raciais subalternizados, desenvolvem uma análise mais complexa da modernidade/colonialidade. Estas autoras enfatizam que as formas de construção e produção social sustentadas pela matriz colonial se encontram atravessadas pela construção hierárquica das raças e também pelas formas relativas à diferença masculino/feminino, regulada pelo sistema patriarcal, que controla duplamente pelo gênero e pela raça (PALERMO, 2012; LUGONES, 2008; CURIEL, 2007, 2009, 2016).

Essas pensadoras deflagram o entrelaçamento do poder patriarcal no capitalismo colonial, desenvolvendo uma análise das relações de saber-poder por ele instituídas que considera a "imbricação" (CURIEL, 2009) dos sistemas de dominação (racismo, sexismo, exploração de classe). Como aponta a feminista decolonial afro-dominicana Ochy Curiel (2009), a imbricação como ferramenta de 
análise das relações de poder e saber instituídas na modernidade/colonialidade possibilita perceber, por exemplo, que as violências que incidem sobre os corpos sexuados femininos tomam formas diferentes de acordo com grupo racial e econômico a que pertencem. Uma dessas diferenças está no modo como essas violências são percebidas e legitimadas socialmente, colocando as mulheres negras e não brancas, especialmente das classes econômicas mais baixas, em posição de maior vulnerabilidade e invisibilização.

No terceiro capítulo aprofundamos a análise sobre as condições das mulheres no que a socióloga e feminista decolonial argentina Maria de Lugones (2008) denominou Sistema de Gênero Moderno/Colonial. Colocamos assim em questão a construção social do gênero na modernidade/colonialidade, considerando a imbricação dos sistemas de dominação e seus efeitos nos diferentes grupos de mulheres, bem como as tensões e hierarquias que gera no interior da classe das mulheres e, portanto, na própria luta feminista.

No quarto capítulo, discutimos a colonialidade na educação e seus impactos na produção do fracasso e abandono escolar. Traçando o percurso histórico da instituição da rede de educação pública, gratuita e obrigatória no Brasil, deflagramos sua estrutura colonial e as persistências desta lógica ainda hoje. Esta perspectiva revela o racismo e o classismo que fundam a escola e os impactos políticos e subjetivos disso na trajetória escolar dos/as estudantes dos grupos subalternizados. A partir disso, problematizamos o fracasso e o abandono escolar, bem como o papel que a Psicologia vem sendo chamada a desempenhar com os/as estudantes considerados "desviantes", inclusive refletindo sobre sua contribuição na produção destes.

No quinto e último capítulo, analisamos algumas das especificidades do dito "abandono escolar" de meninas e sua relação com a persistência dos papéis sexuais instituídos pela ordem patriarcal colonial, que também funda a escola. Nessa discussão, problematizamos o papel da escola na produção do abandono, o que nos leva a colocar em questão o próprio termo "abandono escolar" e seu caráter individualizante.

É nos encontros, nas vozes, nos olhares, nos corpos e nas histórias que se cruzam no espaço escolar que buscamos encontrar não as respostas, mas as 
perguntas que vem sendo silenciadas nestas instituições e que, ao não serem feitas, colaboram com a naturalização da opressão. Não há, portanto, a pretensão de construir verdades absolutas supostamente capazes de dar conta da totalidade dos processos que acometem a vida de todas as meninas e mulheres. Compreendemos que toda análise se constrói a partir de um lugar e essa localização atravessa transformando nossa relação com o mundo e com o que produzimos nele, inclusive o saber. Deste lugar podemos enxergar certas coisas e não outras, havendo, portanto, limites de compreensão das experiências que se constituem a partir de outros lugares. Neste sentido, consideramos importante situar o lugar a partir do qual este estudo se constrói, isto é, de onde fala a pesquisadora: mulher, branca, mãe, feminista, psicóloga, servidora pública, criada em um centro urbano e que há aproximadamente oito anos se mudou para um município menor em função do trabalho, vivendo e colocando em questão muitas experiências transformadoras em vários âmbitos a partir dos encontros proporcionados por essa mudança.

Também é necessário ressaltar que não pretendemos ${ }^{4}$ fazer uma análise da realidade da cidade de Paraty, tratando as questões abordadas como processos exclusivos deste município. Partimos da minha experiência como psicóloga atuando no campo da educação para pensar mais amplamente as linhas de força presentes na marginalização de meninas brasileiras da esfera educacional pública, marcando as singularidades constituídas por processos históricos bem determinados e que reverberam ainda hoje, principalmente nesses corpos-vidas. Deste modo, trata-se de uma pesquisa teórica, mas que dialoga com um campo de experiências, que é convocado em momentos estratégicos em que o compartilhamento das experiências vividas contribui para a compreensão dos modos como os jogos de poder se dão na prática.

\footnotetext{
${ }^{4}$ Esclareço que no decorrer da tese, para me referir aos episódios por mim vividos na escola, utilizarei a primeira pessoa do singular. No entanto, nas análises e problematizações, utilizarei a terceira pessoa, incluindo as tantas vozes que junto comigo possibilitaram tais análises.
} 


\section{CAPÍTULO 2. MODERNIDADE/COLONIALIDADE E RELAÇÕES DE PODER E SABER}

\section{1. "Coração Americano, acordei de um sonho estranho"5: a construção colonial do poder e do saber modernos}

Foi somente quando comecei a colocar em análise de modo mais profundo como o racismo e o sexismo constituem e operam no espaço escolar e nas relações que nele se estabelecem, que percebi que ao longo da minha vida educacional praticamente não havia lido pensadoras/es negras/os e/ou latino-americanas/os. Não havia lido na escola (exceto algumas obras literárias, sempre tratadas como algo secundário em relação ao saber "científico"). Na graduação, li muito poucos. No mestrado, idem. E isto especialmente me atordoou.

Em minha dissertação de mestrado analisei criticamente a interface da Psicologia com o Sistema Socioeducativo da cidade do Rio de Janeiro, colocando em questão o modo como a psicologia vinha servindo a esse sistema, que é estruturalmente classista e racista (PFEIL, 2013). Deste modo, não era novidade pra mim que o racismo constitui e opera em nossas instituições sociais. Foi necessário me informar com certa profundidade sobre tal questão para construir a argumentação teórica da minha pesquisa. No entanto, e por mais incoerente que isto hoje me pareça, ao olhar para bibliografia utilizada, percebo o quão embranquecida, masculina e eurocentrada ela é.

Sem a intenção de me eximir por completo da responsabilidade pela escolha desta bibliografia, é preciso colocar em questão em que contexto ela foi inquestionavelmente (seja por mim, por professores ou por colegas de pesquisa) utilizada. Se a resposta para tal questão é complexa, em certa medida, é também bastante evidente. Basta olharmos ao redor dos campis universitários e veremos que a universidade é branca. Estudantes e, especialmente, professores/as universitários são majoritariamente brancos (BELTRÃO E TEIXEIRA, 2004). Por mais que esta realidade venha sendo lentamente modificada com as políticas

\footnotetext{
${ }^{5}$ Trecho da música San Vicente, de Milton Nascimento e Fernando Brant.
} 
de ação afirmativa implementadas a partir de $2004^{6}$, ainda é, em grande medida, assim que este espaço se configura.

Se o olhar se volta aos currículos, ementas e referências bibliográficas das disciplinas dos cursos percebemos que a academia além de branca é masculina, eurocentrada e heteronormativa. Como este cenário se constitui?

Foi a partir das minhas experiências profissionais na escola, particularmente na rede pública de ensino, onde nos confrontamos a todo o momento com uma intensa multiplicidade étnico-racial, que fui levada a questionar a formação acadêmica. Um primeiro estranhamento foi a percepção de que as ferramentas teóricas e técnicas das quais dispunha não davam conta de responder e criar efetivamente estratégias de ação para lidar com as situações e demandas cotidianas. Havia um abismo entre a teoria aprendida na universidade e a complexa realidade no campo da prática profissional. Tal percepção me levou a mexer no que se encontrava estratégica e confortavelmente intocado: a parcialidade classista, racista e sexista dos saberes. Olhar para isso foi começar a tomar consciência dos efeitos da persistente lógica colonial que ainda hoje rege nossos modos de pensar e sentir o mundo, seus fenômenos, suas relações, bem como nossa formação educacional e profissional e a produção de conhecimento.

O sociólogo peruano Aníbal Quijano (1997) aponta que, mesmo com o fim formal do colonialismo político, a relação entre a cultura europeia ("ocidental") e as outras seguiu sendo uma relação de dominação colonial. É no desenvolvimento desta ideia que este autor cria a noção de colonialidade, definindo-a como uma prática que ultrapassa as particularidades do colonialismo histórico, não se extinguindo com a independência ou descolonização. Há na criação deste conceito uma tentativa de explicar a modernidade como um processo profundamente ligado à experiência colonial.

Os efeitos do colonialismo nas sociedades contemporâneas começam a ser colocados em pauta a partir das lutas concretas pela descolonização e pelo fim do apartheid em África e Ásia, nos anos 50 e 60, pela luta por direitos civis nos Estados Unidos e pelo feminismo construído por mulheres negras desde os anos

\footnotetext{
${ }^{6}$ predominantemente as cotas sociais e étnico-raciais no setor público e as bolsas de estudo no setor privado, em parte financiadas pelo Prouni.
} 
60, quando surgem também as primeiras propostas de ação em relação a essa problemática (CURIEL, 2007). Isto é, tais pensamentos e ações se iniciam por meio dos movimentos sociais para depois serem formulados enquanto teorias.

Dentre as principais referências na análise desses efeitos, estão os pensadores AiméCésaire, na década de 30, e Frantz Fanon, na década de 50. Césaire foi um poeta, dramaturgo e político, nascido na Martinica, então colônia francesa, que analisou o colonialismo e o racismo como vetores fundamentais do capitalismo e da modernidade ocidental tanto no que diz respeito às relações econômicas quanto a construção de pensamentos e valores eurocentrados (CÉSAIRE, 1978). Fanon, psiquiatra anticolonialista radical martinicano e aluno, amigo e apoiador Césaire, faz referência a um mundo dividido entre colonizadores e colonizados, em que estes foram desumanizados e subalternizados por aqueles, através do racismo. Para ele, o racismo é uma consequência da forma específica de exploração capitalista que foi $\mathrm{o}$ colonialismo, fazendo parte do conjunto de estratégias de poder que atuam na opressão sistematizada do povo que se pretende dominar (FANON, 1980). A partir disso, considera as estruturas sociais coloniais e analisa como elas são introjetadas na subjetividade do colonizado, apontando como caminho para a mudança uma transformação radical das estruturas da sociedade (FANON, 2008). Nesta perspectiva, propõe a descolonização não apenas das colônias frente às metrópoles, mas das subjetividades colonizadas, a partir da negação da identidade imposta aos colonizados pelos colonizadores.

As ideias formuladas por Césaire e Fanon oferecem uma profunda análise do colonialismo a partir do que hoje se denomina "posições subalternas" (CURIEL, 2007). São intelectuais negros que desafiaram profundamente o eurocentrismo do saber e do poder. Como aponta Curiel (2007), é sobre as bases das ideias formuladas por esses dois pensadores, que a noção de colonialidade se funda e se aprofunda pelos/as pensadores/as do Sul Global.

Os estudos denominados pós-coloniais, subalternos ou decoloniais, realizados na África, Ásia e América Latina - entendidos como lugares que ativam o pensamento crítico emancipador e não meramente como territórios geográficos - vêm articulando uma perspectiva que explicita o caráter colonial da expansão capitalista e de seu projeto cultural (ASSIS, 2014). Nesta visão, a ideia 
de que as Américas foram incorporadas dentro de uma economia mundial capitalista já existente é substituída pela de que, na realidade, não haveria uma economia capitalista mundial sem a existência das Américas.

O moderno sistema mundial nasceu no longo do século XVI. As Américas, como construto social, nasceram no século XVI. A criação dessa entidade geossocial, as Américas, foi o ato constitutivo do sistema mundial moderno. As Américas não foram incorporadas a uma economia capitalista mundial já existente. Não poderia ter havido economia capitalista mundial sem as Américas (QUIJANO \& WALLERSTEIN, 1992, p. 549, tradução nossa ${ }^{7}$ ).

O semiólogo argentino Walter Mignolo (2003) compreende a colonialidade como a face oculta e obscura da narrativa europeia que é a modernidade, considerando que a existência desta não seria possível sem a colonialidade. De acordo com o autor, o novo circuito comercial iniciado no século XVI, conectou o Mediterrâneo com o Atlântico e lançou as fundações tanto da modernidade como da colonialidade.

Avançando nas análises feitas por Edward Said, Mignolo aponta que foi também esse novo circuito que criou condições para a instauração de um novo imaginário global que dividiu o mundo entre Ocidente e Oriente, tornando o "ocidentalismo" o "imaginário geopolítico dominante do sistema mundial colonial/moderno" (MIGNOLO, 2003, p. 91). Para o autor, esta divisão foi fundamental para subalternizar o conhecimento e estabelecer, simultaneamente, um padrão epistemológico planetário.

Mignolo (2003) afirma que é sobre o que chamou de "diferença colonial" que se assenta a modernidade e a articulação e crescimento do capitalismo global. De acordo com ele, a diferença colonial se cria e se instala no entremeio do projeto modernidade/colonialidade, tratando de transformar a multiplicidade cultural em valores e hierarquias raciais, sexuais e geopolíticas. Quem classifica controla o conhecimento e, neste sentido, a diferença colonial é uma estratégia fundamental para subalternizar populações e regiões do mundo.

\footnotetext{
7،"The modern world-system wasborn in thelongsixteemthcentury. The Americas as a geosocial constructo wereborn in thelongsixteenthcentury. The creationofthisgeosocialentity, theAmericas, wastheconstitutiveactofthemodern world-system. The Americaswerenotincorporatedinto as alreadyexisting capitalista world-economy. Therecouldnothavebeen a capitalist worldeconomywothouttheAmericas".
} 
A perspectiva de análise construída pelos estudos decoloniais considera que no processo de constituição da modernidade se engendram três facetas articuladas da colonialidade: a colonialidade do poder, a colonialidade do saber e a colonialidade do ser. Estas operam de modo a criar uma geopolítica que posiciona a Europa no centro e as outras regiões do mundo, as sociedades provenientes de outros territórios, à margem.

Quijano (1997) afirma que a "colonialidade de poder" estabelece e fixa uma hierarquia racializada, onde brancos (europeus) ocupam o topo, seguidos por "mestiços", "índios" e "negros" tidos como identidades comuns e negativas. Neste contexto, categorias binárias como oriente-ocidente, primitivo-civilizado, místicocientífico, tradicional-moderno servem para "justificar a superioridade e a inferioridade, racionalidade e irracionalidade, humanização e desumanização (colonialidade do ser) e pressupõem o eurocentrismo como perspectiva hegemônica (colonialidade do saber)" (WALSH, 2009, p. 15).

O cientista social cubano Carlos Moore (2007), em seus estudos sobre a gênese do racismo, afirma que "a hostilidade e o medo da cor especificamente negra é um fenômeno francamente universal que se encontra nos mitos e nas culturas de praticamente todos os povos não-negros" (pp. 49-50). De acordo com o autor, essa constatação pode ser verificada por intermédio do exame dos mitos arquetípicos dos povos euro-semitas da Europa e do Oriente Médio, sugerindo, sem dúvida, "a ocorrência, em épocas longínquas, de graves conflitos entre povos melanodérmicos e leucodérmicos nessas regiões" (p. 50).

No entanto, para Quijano (1997), como sede e fonte de relações sociais e culturais concretas fundadas em diferenças biológicas, a ideia de "raça" se forja junto com a América. De acordo com o autor, elas se dão no mesmo movimento histórico que o mundo do capitalismo colonial moderno, que posiciona a Europa no centro.

[...] os colonizadores definiram a nova identidade das populações aborígenes colonizadas "índios". Para essas populações a dominação colonial implicava, em consequência a desapropriação e a repressão das identidades originais (mayas, astecas, incas, aymaras, etc., etc.), e a longo prazo a perda destas e admissão de uma comum identidade negativa. A população de origem africana, também procedente de heterogêneas experiências e identidades históricas (congos, bacongos, yorubas, ashantis, etc., etc.) foi submetida a uma situação equivalente em todo o fundamental e a uma comum identidade colonial, igualmente negativa: 
"negros". Os colonizadores se identificavam no começo como "espanhóis", "portugueses" ou "ibéricos", "britânicos", etc., etc. Já ao final do século XVIII, e, sobretudo depois das guerras chamadas de "emancipação", se identificaram como "europeus", ou mais genericamente como "brancos". E os descendentes das relações genéticas entre todas essas novas identidades, seriam conhecidos como "mestiços" (QUIJANO, 1997, p. 120, tradução nossa ${ }^{8}$ ).

Mignolo (2003) denomina "colonialidade do saber" a imposição de formas hegemônicas de conhecimento, isto é, a criação de uma geopolítica do conhecimento estratégica à dominação europeia sobre os territórios e povos colonizados. Nesta organização, as teorias, conhecimentos e paradigmas forjados na Europa são impostos como os verdadeiros e universais, enquanto tudo o que é produzido fora deste território é alocado na categoria de conhecimento "outro", "diferente" e inferior.

Como aponta o sociólogo venezuelano Edgardo Lander (2005), é com o colonialismo que se inicia a organização colonial do mundo em termos de saberes, linguagens, memória e imaginário. Ele afirma que:

Dá-se início ao longo processo que culminará nos séculos XVIII e XIX e no qual, pela primeira vez, se organiza a totalidade do espaço e do tempo - todas as culturas, povos e territórios do planeta, presentes e passados numa grande narrativa universal. Nessa narrativa, a Europa é ou sempre foi simultaneamente o centro geográfico e a culminação do movimento temporal. Nesse período moderno primevo/colonial dão-se os primeiros passos na articulação das diferenças culturais em hierarquias cronológicas (Mignolo, 1995: xi) e do que Johannes Fabian chama de a negação da simultaneidade (negation of coevalness). Com os cronistas espanhóis dá-se início à massiva formação discursiva de construção da Europa/Ocidente e o outro, do europeu e o índio, do lugar privilegiado do lugar de enunciação associado ao poder imperial (Mignolo, 1995: 328) (LANDER, 2005, p. 10).

Para Lander, a colonialidade do saber nos revela um legado epistemológico do eurocentrismo, que se soma ao legado de desigualdade e injustiça sociais profundos do colonialismo e do imperialismo. Este legado

\footnotetext{
8“"los colonizadores definieron la nueva identidad de las poblaciones aborlgenes colonizadas: "indios". Para esas poblaciones la dominación colonial implicaba, en consecuencia, el despojo y la represión de las identidades originales (mayas, aztecas, incas, aymaras, etc., etc., etc.) y en el largo plazo la pérdi-

da de éstas y la admisión de una común identidad negativa. La población de origen africano, también procedente de heterogéneas experiencias e identidades históricas (congas, bacongos, yorubas, ashantis, etc., etc.), fue sometida a una situación equivalente en todo lo fundamental y a una común identidad colonial, igualmente negativa: "negros". Los colonizadores se identificarian al comienzo como "españoles", "portugueses", o "ibéricos", "británicos". etc. Ya desde fines del siglo XVIII, y sobre todo tras las guerras llamadas de "Emancipación". se identificarian como "europeos" o, más genéricamente, como "blancos". Y los descendientes de las relaciones genéticas entre todas esas nuevas identidades serian conocidos como "mestizos"”.
} 
impossibilita nossa compreensão do mundo a partir do próprio mundo em que vivemos e de suas próprias epistemes. Impede-nos de perceber que "o pensamento está em todos os lugares onde os diferentes povos e suas culturas se desenvolveram e, assim, são múltiplas as epistemes com seus muitos mundos de vida" (PORTO-GONÇALVES, 2005, p. 4).

Como aponta Quijano (1992), permanece uma colonização cultural que consiste, primeiramente, em uma colonização do imaginário dos dominados, atuando em sua interioridade e, em certa medida, sendo parte dele. Este foi o produto de uma sistemática repressão a específicas crenças, ideias, imagens, símbolos ou conhecimentos, que serviram para a dominação colonial global. Repressão que recaiu sobre "os modos de conhecer, de produzir conhecimento, de produzir perspectivas, imagens e sistemas de imagens, símbolos, modos de significação: sobre os recursos, padrões e instrumentos de expressão formalizada e objetivada, intelectual ou visual" (QUIJANO, 1992, p. 12, tradução nossa9 ${ }^{9}$ ).

De acordo com Quijano (1992), os próprios padrões de produção de conhecimento e significações dos colonizadores foram impostos sobre uma imagem mistificada, tendo a princípio seu acesso negado aos dominados. Mais adiante, foi compartilhado seletivamente, com o objetivo de cooptar alguns dominados em algumas instâncias de poder dos dominadores. Nesta etapa, a cultura europeia se torna o caminho sedutor que dá acesso ao poder e, portanto, a europeização cultural uma aspiração. Como acentua o sociólogo porto-riquenho Ramón Grosfoguel (2008), o êxito do sistema-mundo capitalista colonialmoderno encontra-se na sua capacidade de levar os sujeitos socialmente situados no lado subalternizado da diferença colonial a pensar epistemicamente como os que estão nas posições dominantes.

De acordo com Mignolo (2003), esse processo, marcado por uma violência epistêmica, levou a uma geopolítica linguística. As línguas das populações nativas dos territórios colonizados foram desprezadas em detrimento das línguas coloniais, tendo como consequência a subversão e silenciamento de ideias, imaginários e das próprias cosmovisões dessas populações. Como aponta

\footnotetext{
9 "La represionrecayo, ante todo, sobre los modos de conocer, de producir conocimiento, de producir perspectivas, imagenes y sistemas de imagenes, simbolos, modos de significacion; sobre los recursos, patrones e instrumentos de expresionfonnalizada y objetivada, intelectual o visual".
} 
Catherine Walsh (2009), socióloga norte-americana radicada no Equador, a medida que silenciam e inviabilizam os modos de vida e de conhecimento dos povos colonizados, essas operações põem em dúvida o valor humano dessas pessoas.

Esse processo é compreendido pelo porto-riquenho Nelson MaldonadoTorres (2007) como "colonialidade do ser", que promove a negação do estatuto de humanidade as/aos negras/os africanos e as/aos indígenas de Abya Yala ${ }^{10}$, impondo a eles uma série de cerceamentos tanto materiais quanto subjetivos. De acordo com o autor, tais populações foram consideradas um obstáculo para a cristianização e modernização, sendo a desumanização a justificativa para sua escravização, expropriação de terras, desqualificação de saberes (colonialidade do saber) e genocídio.

Walsh (2009) considera que há ainda uma quarta dimensão da colonialidade, por ela denominada cosmogônica ou da mãe natureza. Ela esta relacionada à força vital-mágico-espiritual da existência das comunidades afrodescendentes e indígenas, em suas particularidades históricas. A autora aponta:

É a que se fixa na diferença binária cartesiana entre homem/natureza, categorizando como não-modernas, "primitivas" e "pagãs" as relações espirituais e sagradas que conectam os mundos de cima e de baixo, com a terra e com os ancestrais como seres vivos. Assim, pretende anular as cosmovisões, filosofias, religiosidades, princípios e sistemas de vida, ou seja, a continuidade civilizatória das comunidades indígenas e as da diáspora africana. [...] essa é uma dimensão que permite aprofundar o problema existencial ontológico, particularmente dos descendentes africanos, um problema enraizado não só na desumanização do ser, mas também na negação e destruição de sua coletividade diaspórico-civilizatória e sua filosofia, como razão e prática de existência (p. 15).

Lander (2005) considera que há duas dimensões constitutivas dos saberes modernos que dão sustento sólido a uma construção discursiva neutralizadora dos saberes sociais. A primeira são as sucessivas e históricas repartições do mundo na sociedade ocidental para produzir conhecimento sobre ele. A segunda é o modo

\footnotetext{
10 "Abya Yala, na língua do povo Kuna, significa Terra madura, Terra Viva ou Terra em florescimento e é sinônimo de América. [...] Abya Yala vem sendo usado como uma autodesignação dos povos originários do continente em oposição a América, expressão que, embora usada pela primeira vez em 1507 pelo cosmólogo Martin Wakdseemüller, só se consagra a partir de finais do século XVIII e inícios do século XIX, adotada pelas elites crioulas para se afirmarem em contraponto aos conquistadores europeus, no bojo do processo de independência. Muito embora os diferentes povos originários que habitavam o continente atribuíssem nomes próprios às regiões que ocupavam - Tawantinsuyu, Anauhuac, Pindorama -, a expressão Abya Yala vem sendo cada vez mais usada por esses povos, objetivando construir um sentimento de unidade e pertencimento" (PORTO-GONÇALVES, 2009, p. 26).
} 
como esses saberes modernos se articulam com a organização do poder, em especial as relações coloniais/imperiais de poder constitutivas do mundo moderno.

Para Lander (2005), na autoconsciência europeia da modernidade, as sucessivas repartições do mundo para produzir conhecimento sobre ele "se articulam com aquelas que servem de fundamento ao contraste essencial estabelecido a partir da conformação colonial do mundo entre ocidental ou europeu (concebido como o moderno, o avançado) e os "Outros", o restante dos povos e culturas do planeta" (p. 10). Dentre as repartições do mundo instituídas pelo discurso ocidental está a de origem religiosa judaico-cristã, que separa Deus (o sagrado), homem (o humano) e natureza. Tal visão parte da ideia de que Deus criou o homem à sua própria imagem e semelhança elevando-o acima de todas as outras criaturas e, desta maneira, concedendo-lhe o direito de intervir no curso dos acontecimentos da terra (BERTING, 1993 apud LANDER, 2005).

Mas é com o desenvolvimento posterior das ciências modernas que essas separações são sistematizadas e multiplicadas. Como aponta Lander (2005), a ruptura ontológica entre corpo e mente, razão e mundo, tal como formulada na obra de Descartes, é um marco histórico significativo nos sucessivos processos de separação. Para Apffel-Marglin "esta separação total entre mente e corpo deixou o mundo e o corpo vazios de significado e subjetivou radicalmente a mente", colocando "os seres humanos numa posição externa ao corpo e ao mundo, com uma postura instrumental frente a eles" (1996, p. 4 apud LANDER, 2005, p. 9). $\mathrm{Na}$ construção de saberes sobre o indivíduo, particularmente da Psicologia, o pensamento cartesiano tem grande influência.

Quijano (1992) considera que o pressuposto fundante do paradigma europeu do conhecimento racional é a compreensão de que o conhecimento é produto de uma relação sujeito-objeto. Para o autor, há muitos problemas nas concepções de sujeito e objeto admitidas por essa racionalidade, o que incide diretamente na produção de conhecimento.

A concepção de sujeito assumida nesse pressuposto é uma categoria cartesiana de indivíduo isolado, que se constitui em si e antes de si mesmo, tanto em seu discurso quanto em sua capacidade de reflexão. Da mesma maneira, é problemática a ideia de "objeto" como uma entidade diferente ao sujeito/indivíduo 
e a ele externa por sua natureza. E ainda, a noção de "objeto" como idêntico a si mesmo, constituído de "propriedades" que the atribuem essa identidade, o definindo e localizando em relação a outros objetos.

O que está em questão nesse paradigma é primeiro, o caráter individual e individualista do "sujeito", que como toda meia verdade, falsifica o problema ao negar a intersubjetividade e totalidade social como sede da produção de todo conhecimento. Segundo, a ideia de "objeto" não é compatível com o conhecimento a que chega a investigação científica atual, segundo as quais "propriedades" são modos e momentos de um dado campo de relações, e em consequência não há muito lugar para uma ideia de identidade, de originalidade ontologicamente irredutível, à margem de um campo de relações. Terceiro, a exterioridade das relações entre "sujeito" e "objeto", baseada em diferenças de natureza, é uma exacerbação arbitrária das diferenças, posto que a investigação atual leva a descoberta de que há uma estrutura de comunicação mais profunda no universo (p. 15, tradução nossa ${ }^{11}$ ).

Quijano argumenta que ainda que possamos reconhecer a existência da subjetividade singular, não podemos admitir que esta exista antes ou por si só. Ela é parte diferenciada de uma intersubjetividade, mas não dela separada. Como aponta o psicólogo social Ignacio Martín-Baró (2017), as pessoas não são seres lançados no vazio, mas parte de uma história, agindo imersas nas múltiplas redes de vinculações sociais. Assim, tudo aquilo que constitui uma ação como social “não é um processo que se reduz à mera conexão externa entre um estímulo e uma resposta que já estão dados", mas "um elemento interno da própria ação, que adquire significado transindividual na relação com os outros" (p. 111). Todo discurso, reflexão, problematização realizada por um sujeito, remete a uma estrutura de intersubjetividade, ou seja, está por e nela constituída. Neste sentido, o conhecimento é uma relação intersubjetiva que visa algo, tem uma intencionalidade, e não uma relação entre uma subjetividade "ensimesmada" e esse algo.

Quijano (1992) considera que, no paradigma europeu, o conhecimento foi pensado do mesmo modo que a propriedade, como uma relação entre um

\footnotetext{
11 "Lo que está en cuestión en ese paradigma., es, primero, el carácter individual e individualista del "sujeto", que como toda verdad a medias falsea el problema al negar la intersubjetividad y la totalidad social, como sedes de la producción de todo conocimiento. Segundo, la idea de "objeto" no es compatible con el conocimiento a que llega la investigación científica actual, según el cuallas "propiedades" son modos y momentos de un dado campo de relaciones, y en consecuencia no hay mucho lugar para una idea de identidad, de originalidad ontológicamente irreductible, al margen de un campo de relaciones. Tercero, la exterioridad de las relaciones entre "sujeto" y "objeto", fundada en diferencias de naturaleza, es una exacerbación arbitraria de las diferencias, puesto que la investigaci6n actual llega mas bien al descubrimiento de que hay una estructura de comunicación más profunda en el universo".
} 
indivíduo e algo, e isso não ocorreu por acaso. Para o autor, há um mesmo mecanismo mental subjacente em ambas as ideias no momento de constituição da sociedade moderna. No entanto, na realidade, tanto a propriedade como o conhecimento são relações entre pessoas que objetivam algo, isto é, elas se constituem com propósito, não havendo, portanto, neutralidade nessa relação. Ele salienta que a diferença entre um fenômeno e outro é que a relação de propriedade se dá tanto de modo material quanto intersubjetivo, enquanto que no conhecimento a relação é apenas intersubjetiva.

Para Quijano, a consequência da ausência radical do "outro" é, sobretudo, a omissão de todas as referências a todo "outro sujeito" fora do contexto europeu. Isto torna invisível a ordem colonial como totalidade, no momento em que a própria ideia de Europa está se constituindo justamente por relação ao resto do mundo em colonização (QUIJANO, 1992). Uma vez postulada uma correlação entre sujeito e objeto, institui-se a ideia de que não há "sujeito conhecedor para além do sujeito de conhecimento postulado pelo próprio conceito de racionalidade erigido pela epistemologia moderna" (MIGNOLO, 2003, p. 91).

Essa ideia está nas bases das formações acadêmicas modernas. Há colonialidade no conhecimento produzido no interior das universidades. Há dominação, hierarquização, silenciamento de muitas vozes, saberes, corpos e vidas e nenhuma neutralidade. Afinal, quem são os cânones do pensamento científico moderno? A que grupo racial pertencem? Quais as suas nacionalidades? A que grupo sexual pertencem? E quem é sujeito para as ciências modernas? Quem não é? Do alto do abismo entre teoria e prática com o qual me deparei quando iniciei minha atuação profissional nas escolas ecoavam essas perguntas, que levavam então a outra: a serviço de que e de quem está o conhecimento produzido nessas instituições, sobre essas bases?

Como aponta a psicóloga e artista portuguesa Grada Kilomba (2019), conceitos de conhecimento, erudição e ciência estão intrinsecamente ligados ao poder e à autoridade racial. Isto institui uma ordem científica que reconhece como conhecimento apenas o que é construído pelo grupo de brancos, silenciando a voz daquelas/es pertencentes aos grupos "Outros". Neste processo, como analisa a autora, nas salas de aula das universidades, pessoas negras foram transformadas 
em objetos de discursos brancos, sendo raramente vistas como sujeitos. Como efeito importante disso não esta a falta de resistência ou interesse da comunidade negra, mas a falta de acesso à representação.

Não é que nós não tenhamos falado, o fato é que nossas vozes, graças a um sistema racista, tem sido sistematicamente desqualificadas, consideradas conhecimento inválido; ou então representadas por pessoas brancas que, ironicamente, tornam-se "especialistas" em nossa cultura, e mesmo em nós (KILOMBA, 2019, p. 51).

Para Kilomba, de todas as maneiras, há uma captura das/os subalternizados pela ordem colonial. Vista desta maneira, a suposta neutralidade da academia é colocada em cheque, bem como a visão desta como um mero espaço de conhecimento e produção científica, mas ainda como um lugar de violência e colonização. Um espaço onde a ordem colonial não só é reproduzida como atualizada e, neste sentido, produzida, com o objetivo de se manter. Isto se dá especialmente pela validação dos conhecimentos produzidos pela classe racial e sexual dominante e marginalização ou mesmo negação de tudo que é produzido em termos de saber pelas classes subalternizadas.

O diálogo com as feministas, em especial com aquelas pertencentes aos grupos raciais e econômicos subalternizados, faz perceber que é imprescindível para avançarmos nas análises sobre a colonialidade e seus efeitos de poder e saber, reconhecer que a criação do sujeito universal europeu, além de branca, é masculina e heterossexual. Isto é, o sujeito do conhecimento e do poder fundado pelo colonialismo é homem branco heterossexual. Ramón Grosfoguel (2012), também aponta nesse sentido, ao afirmar "o homem branco, capitalista, heterossexual, militar, cristão, europeu foi o que se expandiu pelo mundo levando consigo, e impondo simultaneamente, os privilégios de sua posição racial, militar, de classe, sexual, epistêmica, espiritual e de gênero" (p. 343). Foram estas diversas colonialidades entrelaçadas que fundamentalmente possibilitaram a imposição das hierarquias e ideologias globais que experienciamos ainda hoje em escala planetária. 


\subsection{Despatriarcalizar para descolonizar: a construção de uma perspectiva feminista decolonial das relações de poder e saber modernas/coloniais}

Como vimos, de acordo com os pensadores decoloniais com os quais dialogamos, a colonialidade é um padrão mundial de dominação, que constitui e é constituído no modelo capitalista e persiste até os dias atuais. Trata-se de um sistema de dominação pautado por um modelo hegemônico eurocentrado, que tem impacto nas relações intersubjetivas e culturais, na produção de conhecimento, na divisão social do trabalho, nos modos de vida, de expressão e no corpo, visto como território de exercício de poder (QUIJANO, 1997; MIGNOLO, 2003; LANDER; 2005).

Mas, para Curiel (2007), se podemos ver nas análises desenvolvidas por esses pensadores a raça bem situada como critério de classificação de populações, isto se faz superficialmente em relação ao sexo e a sexualidade e sem referências aos aportes das muitas feministas que criaram esse pensamento. Em contrapartida, a autora aponta que as feministas pertencentes aos grupos raciais subalternizados, afrodescendentes e indígenas, mesmo sem usar o conceito de colonialidade, desde os anos setenta, vêm produzindo análises muito mais profundas sobre suas condições no interior de processos históricos como a colonização e a escravidão. Análises que se voltam à articulação do poder patriarcal e capitalista, considerando o entrelaçamento dos diversos sistemas de dominação (racismo, sexismo, heteronormatividade, classismo), através do qual tem definido seus projetos políticos.

Tais feministas vêm, de seus diferentes lugares, criticando a superficialidade das análises do caráter sexista da colonialidade. Para elas, é impossível entender a desapropriação causada pelo fato colonial sem abordar a dimensão patriarcal. Nesta perspectiva defendem que não há descolonização sem despatriarcalização (MIÑOSO; CORREAL; MUÑOZ, 2014), isto é, as lutas contra o capitalismo, o racismo, a homofobia e toda forma de dominação relacionada com o sistema capitalista moderno/colonial têm necessariamente que incorporar estratégias de despatriarcalização. 
No entanto, como aponta Curiel, tais análises não têm sido consideradas como deveriam. A autora considera que isto ocorre principalmente porque certos setores no âmbito acadêmico e político, por mais que tenham se esforçado em abrir brechas ao que se denomina "subalternidade", ainda partem de posições e perspectivas elitistas e, sobretudo, masculinas e androcêntricas.

No que se refere a história e produção de conhecimento, a historiadora austríaca Gerda Lerner (2019), em seus estudos sobre o patriarcado, aponta que apesar das mulheres, igualmente aos homens, terem sido sempre autoras e agentes na história, até um passado recente o registro histórico era monopólio masculino. Isto significava que o que hoje conhecemos como História, declarada como universal, são registros parciais, que trazem um recorte das experiências dos homens e daquilo por eles considerado importante de ser registrado. Neste recorte, os feitos, experiências e interpretações de mulheres são omitidos, silenciados. Nas palavras de Lerner, o "conhecimento histórico, até pouco tempo atrás, considerava as mulheres irrelevantes para a criação da civilização e secundárias para atividades definidas como importantes em termos históricos” (2019, p. 28).

Lerner aponta que ainda que muitos grupos de homens tenham sido eliminados durante muito tempo do registro histórico pelas interpretações tendenciosas feitas por intelectuais das elites no poder, um erro não apaga o outro e ambos devem ser corrigidos. No entanto, ela pontua que é preciso considerar que mesmo quando as experiências de grupos subalternizados, como os campesinos, os escravizados, o proletariado, começaram a tornar-se parte do registro histórico, esta inclusão foi feita, em geral, a partir das narrativas e experiências dos homens pertencentes a estes grupos, ficando as mulheres, como sempre, excluídas. Isto, para a autora, revela que é certo que homens e mulheres têm sido excluídos e discriminados por causa de sua classe racial e/ou econômica, "mas nenhum homem foi excluído do registro histórico por causa do seu sexo, embora todas as mulheres o tenham sido" (2019, p. 29).

Mas essa discussão ganha mais complexidade quando Curiel (2007) também atribui a invisibilização da produção de conhecimento das feministas negras e não brancas à posição eurocentrada e, portanto, racista, a partir da qual grande parte dos estudos feministas se desenvolvem. O que ela denuncia é o 
silenciamento que as próprias mulheres podem impor (e impuseram) umas as outras quando estas relações são atravessadas pelo vetor de opressão "raça".

De acordo com Curiel, tanto o ponto de partida androcêntrico dos estudos subalternos e decoloniais quanto o ponto de partida racista e burguês dos estudos feministas produzem um vácuo teórico e prático no que diz respeito a articulação entre racismo, sexismo e exploração de classe e o que ela impõe aos corpos e vidas marcados pela opressão racial e sexual simultaneamente. Deste modo, acabam por perpetuar o silenciamento e a subalternização das mulheres pertencentes aos grupos raciais e econômicos subalternizados nas próprias análises críticas e lutas emancipatórias.

É a partir dessa análise que surge o feminismo decolonial. Uma proposta formulada por pensadoras e ativistas feministas negras e também pelas lésbicas e as autónomas da América Latina e do Caribe, que busca descolonizar o feminismo - revisando e problematizando suas bases fundamentais - e ampliar conceitos e teorias chaves da teoria decolonial proposta pelos pensadores/as latinoamericanos/as.

Construindo perspectivas críticas a partir de suas próprias experiências e lugares, essas pensadoras e ativistas buscam construir uma proposta de ação coletiva de transformação social em seus contextos. Como define Espinosa:

[o feminismo decolonial é] Por um lado, herdeiro do feminismo negro, de cor e terceiro-mundista nos Estados Unidos, com suas contribuições para pensar na sobreposição de opressões (classe, raça, gênero, sexualidade), ao mesmo tempo em que propõe recuperar o legado crítico das mulheres feministas afrodescendentes e indígenas da América Latina e do Caribe que levantaram o problema de sua invisibilidade dentro de seus movimentos e dentro do próprio feminismo, iniciando um trabalho para revisar o papel e a importância que tiveram na realização e resistência de suas comunidades. Em segundo lugar, o grupo retoma algumas contribuições da teoria feminista produzida na Europa e nos EUA que servem a seus propósitos. Assim, várias das que compõem o grupo adotam o feminismo materialista francês com seus questionamentos iniciais da ideia de natureza, seu entendimento da categoria de mulheres como "classe sexual" e a análise da heterossexualidade como regime político. Também se alimentam da revisão crítica do essencialismo, do sujeito do feminismo e a política de identidade desenvolvida pelo feminismo pós-moderno. Na mesma linha, recuperam o legado das principais autoras do feminismo pós-colonial com suas críticas à violência epistêmica, a possibilidade de um essencialismo estratégico, o apelo à solidariedade feminista norte-sul e a crítica do colonialismo 
na produção de conhecimento da academia feminista situada no norte (ESPINOSA, 2008 apud CURIEL, 2016, pp. 82-83, tradução minha) ${ }^{12}$.

De maneira ampla, descolonizar diz respeito aos processos de independência de povos e territórios submetidos à dominação colonial política, econômica, social e cultural. A América viveu esse processo entre 1783 e 1900, que desencadeou no surgimento dos Estados Unidos e das repúblicas latinoamericanas. Entre 1920 e 1945 ele acontece em relação as dependências do Império Otomano e desde onde surgem as independências de boa parte dos Estados do Oriente Médio e o Maghreb. No continente africano e importantes áreas da Ásia, do Pacífico e do Caribe, as estruturações em unidades independentes ocorre entre 1945 e 1970 (CURIEL, 2009).

Mas quando se refere a processos de descolonização, Curiel (2009) dá ênfase ao último período, considerando este o que causou maior impacto na consciência crítica tanto de intelectuais e ativistas destes continentes quanto em muitos outros - como na América Latina e no Caribe, por exemplo. No âmbito acadêmico, o despertar desta consciência crítica foi o que posteriormente implicou nos estudos pós-coloniais, subalternos e decoloniais, para os quais a construção dos sujeitos em contextos pós-coloniais passa a ser central.

Esses estudos e posicionamentos questionam a relação saber-poder, colocando como premissa, como vimos, que a América é um produto da modernidade na construção do sistema-mundo moderno-colonial, fundado no momento em que a Europa se constitui em torno de sua referência periférica: a própria América. A partir disso, tais estudos se voltam às implicações desta relação, colocando em análise a estrutura de dominação e exploração criada a

\footnotetext{
12 "Por un lado se reclama heredero del feminismo negro, de color y tercermundista en los EEUU, con sus aportes a pensar la imbricación de opresiones (de clase, raza, género, sexualidad), al tiempo que se propone recuperar el legado crítico de las mujeres y feministas afrodescendientes e indígenas que desde América Latina y el Caribe que han planteado el problema de su invisibilidad dentro de sus movimientos y dentro del feminismo mismo, iniciando un trabajo de revisión del papel y la importancia que han tenido en la realización y resistencia de sus comunidades. En segundo lugar, el grupo retoma algunos aportes de la teoría feminista producida en Europa y EEUU que sirven a sus fines. Así, varias de las que componen el grupo, retoman al feminismo materialista francés con su temprano cuestionamiento a la idea de naturaleza, su comprensión de la categoría mujeres como "clase de sexo" y el análisis de la heterosexualidad como régimen político. También se nutren de la revisión crítica del esencialismo, el sujeto del feminismo y la política de identidad desarrollada por el feminismo posmodernista. En este mismo tenor, recuperan el legado de autoras claves del feminismo poscolonial con su crítica a la violencia epistémica, la posibilidad de un esencialismo estratégico el llamado a una solidaridad feminista norte-sur y la crítica al colonialismo de la producción de conocimientos de la academia feminista asentada en el norte".
} 
partir dela e que não foi desmontada com o fim das administrações coloniais, persistindo atualizada.

Um processo de descolonização supõe, assim, realocar o pensamento e a ação, rompendo com a universalização moderna ocidental, através do resgate de propostas epistemológicas e políticas diversas, desde as experiências subalternas. Neste sentido, descolonizar é uma posição política que atravessa o pensamento, o imaginário, o corpo, a sexualidade e a ação dos sujeitos, bem como de seus coletivos. Trata-se de "compreender a complexidade das relações e subordinações que se exercem sobre aqueles/as considerados/as "outros" (CURIEL, 2007, p. 100 , tradução nossa ${ }^{13}$ ).

É analisando essas relações de poder e saber a partir de seus lugares, que feministas decoloniais enfatizam que as formas de construção e produção social sustentadas pela matriz colonial se encontram atravessadas pela construção hierárquica das raças e concomitantemente pelas formas relativas à diferença masculino/feminino, regulada pelo sistema patriarcal. Isto é, a partir da articulação dos sistemas de dominação patriarcal e racista, a colonialidade controla duplamente pelo gênero e pela raça (PALERMO, 2012; LUGONES, 2008; CURIEL, 2007, 2009, 2016). Como afirma a professora argentina Zulma Palermo (2012), é "na diferença gênero/raça onde o Outro é aprisionado em uma totalidade masculinocêntrica, negando a existência da mulher em sua própria alteridade e sexualidade" (p. 20, tradução nossa ${ }^{14}$ ).

Uma das principais referências para o desenvolvimento do pensamento feminista decolonial é o pensamento feminista antirracista e pós-colonial surgido nos anos setenta nos Estados Unidos. De acordo com Curiel (2007), foi o feminismo negro que, ao inter-relacionar categorias como raça, classe, sexo e sexualidade no marco das sociedades pós-coloniais, produziu transformações importantes na teoria e práticas feministas, que contribuíram imensamente para o que hoje é denominado feminismo decolonial.

\footnotetext{
13 "entender la complejidad de relaciones y subordinaciones que se ejercen sobre aquellos/as considerados "otros"”.

14 “es en la diferencia género/raza donde el otro es apresado en una totalidad masculinocéntrica, negando la existencia de la mujer en su propia alteridad y sexualidad".
} 
Dentre os nomes destacados por Curiel nesse pensamento estão: Maria Stewart, primeira mulher negra a falar publicamente sobre racismo e sexismo nos Estados Unidos, 1831; Sojourner Truth e seu discurso "E sou eu uma mulher?", na primeira Convenção Nacional de 1851, em Worcester, Massachussets, onde propunha a todas as mulheres libertarem-se da dominação tanto sexista quanto racista; Rosa Parks, que, em 1955, se negou a ceder lugar a um homem branco na parte dianteira do ônibus, transgredindo assim a lei de segregação racial vigente na época, no sul dos Estados Unidos, o que desencadeou uma série de manifestações da população afronorteamericana, levando, em seguida, ao movimento pelos direitos civis; e Angela Davis, que se destacou na luta pelos direitos civis e trouxe uma fundamental contribuição teórica e prática para o feminismo ao articular a luta de classes com a luta antirracista e a luta feminista.

Curiel ressalta também o importante papel da afronorteamericana Patricia Hill Collins na sistematização do pensamento político intelectual do feminismo negro em que destaca dois dos componentes principais: seu conteúdo temático e seu enfoque epistemológico a partir das experiências concretas e localizadas das mulheres negras.

Para desenvolver definições adequadas do pensamento feminista negro é preciso enfrentar o complexo nó das relações que unem a classificação biológica, a construção social da raça e o gênero como categorias de análise, as condições materiais que acompanham estas construções sociais cambiantes e a consciência das mulheres negras acerca destes temas. Uma maneira de se posicionar frente às tensões de definição no pensamento feminista negro é especificada na relação entre a posição das mulheres negras - aquelas experiências e ideias compartilhadas pelas afroamericanas e que as proporcionam um enfoque singular de si mesmas, da comunidade e da sociedade - e as teorias que interpretam essas experiências $[\ldots]$ o pensamento feminista negro compreende interpretações da 
realidade das mulheres negras feita por mulheres negras ${ }^{15}$ (Collins, 1998, p. 289 apud CURIEL, 2007, p. 95, tradução nossa ${ }^{16}$ ).

É pensando a posição das mulheres negras, que a professora de direito norte-americana Kimberlé Crenshaw (2002) cunha o conceito de interseccionalidade, definindo-o como "uma conceituação do problema que busca capturar as consequências estruturais e dinâmicas da interação entre dois ou mais eixos da subordinação" (p. 177). Especificamente, Crenshaw trata do modo pelo qual "o racismo, o patriarcalismo, a opressão de classe e outros sistemas discriminatórios criam desigualdades básicas que estruturam as posições relativas de mulheres, raças, etnias, classes e outras" e, ainda, "da forma como ações e políticas específicas geram opressões que fluem ao longo de tais eixos, constituindo aspectos dinâmicos ou ativos do desempoderamento" (idem).

O conceito de interseccionalidade foi pensando por Crenshaw a partir do questionamento sobre uma "grande falta" ocorrida dentro da estrutura complexa da lei anti-discriminação nos EUA. Como ponto de partida para sua questão, encontra-se o episódio ocorrido em 1976, em que Emma DeGraffenreid e várias outras mulheres negras processaram a General Motors por discriminação, deflagrando a segregação de raça e gênero operada pela empresa sobre sua força de trabalho. Como conta a autora:

[...] as mulheres eram bem-vindas para se candidatar a alguns empregos, enquanto apenas os homens eram adequados para outros. Obviamente, isso era

\footnotetext{
15 "Para desarrollar definiciones adecuadas del pensamiento feminista negro es preciso enfrentarse al complejo nudo de las relaciones que une la clasificación biológica, la construcción social de la raza y el género como categorías de análisis, las condiciones materiales que acompañan estas construcciones sociales cambiantes y la conciencia de las mujeres negras acerca de estos temas. Una manera de ubicarse frente a las tensiones de definición en el pensamiento feminista negro es especificado en la relación entre la ubicación de las mujeres negras -aquellas experiencias e ideas compartidas por las afroamericanas y que les proporción un enfoque singular de sí mismas, de la comunidad y de la sociedad- y las teorías que interpretan esas experiencias [...] el pensamiento feminista negro comprende interpretaciones de la realidad de las mujeres negras hechas por las mujeres negras".

16 "Para desarrollar definiciones adecuadas del pensamiento feminista negro es preciso enfrentarse al complejo nudo de las relaciones que une la clasificación biológica, la construcción social de la raza y el género como categorías de análisis, las condiciones materiales que acompañan estas construcciones sociales cambiantes y la conciencia de las mujeres negras acerca de estos temas. Una manera de ubicarse frente a las tensiones de definición en el pensamiento feminista negro es especificado en la relación entre la ubicación de las mujeres negras -aquellas experiencias e ideas compartidas por las afroamericanas y que les proporci n un enfoque singular de sí mismas, de la comunidad y de la sociedad- y las teorías que interpretan esas experiencias [...] el pensamie to feminista negro comprende interpretaciones de la realidad de las mujeres negras hechas por las mujeres negras (Collins, 1998: 289)".
} 
um problema por si só, mas para as mulheres negras as consequências foram agravadas. Você vê, os empregos negros eram empregos dos homens, e os empregos das mulheres eram apenas para os brancas. Assim, enquanto um candidato negro pode ser contratado para trabalhar no chão de fábrica, se ele fosse homem; se ela fosse uma mulher negra, não seria considerada. Da mesma forma, uma mulher poderia ser contratada como secretária se fosse branca, mas não teria chance nesse emprego se fosse negra. Nem os empregos negros nem os empregos das mulheres eram apropriados para mulheres negras, pois não eram homens nem brancas. Não era claramente essa discriminação, mesmo que alguns negros e algumas mulheres fossem contratados? (CRENSHAW, 2015, s/p, tradução nossa ${ }^{17}$ ).

O desfecho desse processo para DeGraffenreid e todas as outras mulheres negras foi a negação do provimento pelo tribunal, pois este considerava que mulheres negras não deveriam reivindicar contra as opressões de raça e gênero combinadas. "Como elas não podiam provar que o que aconteceu com elas era como o que aconteceu com mulheres brancas ou homens negros, a discriminação que aconteceu com essas mulheres negras caiu em um vácuo" (CRENSHAW, 2015, tradução nossa).

Diante desse caso, Crenshaw, buscou definir essa profunda invisibilidade em relação à lei, comprendendo que a discriminação tanto racial quanto de gênero se sobrepunha não somente no local de trabalho, mas em outras áreas da vida igualmente importantes. A interseccionalidade foi assim a tentativa de Crenshaw e outras feministas negras de fazer o feminismo, o ativismo antirracista e a lei anti-discriminação cumprirem o papel de destacar os múltiplos caminhos pelos quais a opressão racial e sexual era vivida, tornando os problemas mais fáceis de serem discutidos e compreendidos.

Dessa maneira, a interseccionalidade foi concebida como um modo sensível de analisar, a partir das experiências de mulheres negras com o racismo e o sexismo, a identidade e sua relação com o poder e, assim, compreender mais profundamente o funcionamento da sociedade (GILL E PIRES, 2019). No entanto, Crenshaw salienta que "a interseccionalidade não se trata apenas de

\footnotetext{
17 "womenwerewelcome to applyforsomejobs, whileonlymenweresuitableforothers. Thiswas of course a problem in and of itself, butforblackwomentheconsequenceswerecompounded. Yousee, theblackjobsweremen'sjobs, and thewomen'sjobswereonlyforwhites. Thus, while a blackapplicantmightgethired to workonthe 0xFB02oor of thefactoryif he weremale; ifshewere a blackfemaleshewouldnot be considered. Similarly, a womanmight be hired as a secretaryifshewerewhite, butwouldn'thave a chance at thatjobifshewereblack.

Neithertheblackjobsnorthewomen'sjobswereappropriateforblackwomen, sincetheywereneithermalenorwhite. Wasn'tthisclearlydiscrimination, evenifsomeblacks and somewomenwerehired?"
} 
identidades, mas de instituições que usam a identidade para excluir e privilegiar" (CRENSHAW, 2015). Ela defende que o maior entendimento acerca da operação conjunta entre identidades e poder de um contexto para outro diminui a probabilidade dos movimentos de mudança se fragmentarem.

Em termos de interseccionalidade, a perspectiva elaborada pelo coletivo Combahee River, surgido na cidade de Boston (EUA), na década de 70, e constituído por mulheres lésbicas, feministas negras, não brancas e imigrantes do "terceiro mundo", se destacada. Este coletivo, desde uma visão socialista, elaborou uma análise materialista da situação das mulheres negras (FALQUET, 2018).

As membras desse grupo produziram teorias e práticas que enfatizavam a interseccionalidade da raça, da classe, do gênero e da heterossexualidade na vida das mulheres negras, assumindo um caráter radical. Falquet (2018) destaca a coragem política e pessoal das militantes do Coletivo Combahee River que, em um contexto extremamente racista, "tiveram força para criticar duas intimações naturalistas à solidariedade particularmente fortes, produzidas por correntes essencialistas poderosas nos dois principais movimentos sociais da época: o movimento negro e o feminista" (p. 134). Em suas análises, essas feministas denunciavam, ao mesmo tempo:

[...] a injunção à "sororidade" naturalista-racista de uma parte do feminismo, assim como à política sexual naturalista-nacionalista-patriarcal de uma parte do movimento negro, que colocava as mulheres negras como companheiras naturais complementares e totalmente devotadas aos homens negros (FALQUET, 2018, p. 134).

No manifesto publicado pelo Coletivo Combahee River em 1977, estas feministas afirmam que "a política sexual sob o patriarcado é tão pervasiva nas vidas das mulheres negras quanto são as políticas de raça e classe” (2019, p. 200). Nesta perspectiva, apontam para a existência de uma opressão racial-sexual, que não pode ser reduzida nem a raça nem ao sexo. Desta maneira, para elas, o feminismo negro:

exige solidariedade a respeito da questão racial, o que não é uma necessidade no caso da relação entre mulheres brancas e homens brancos, a menos que seja em termos de uma solidariedade negativa enquanto opressores raciais. Nós lutamos junto de homens negros contra o racismo, enquanto também nos confrontamos com eles a respeito do sexismo (p. 200). 
O Coletivo defende que para a libertação de todos os povos oprimidos é fundamental a destruição dos sistemas político-econômicos capitalistas e imperialistas, assim como do patriarcado. Deste modo, se posicionam como socialistas por acreditarem que o trabalho deve ser organizado para o benefício coletivo de todos aqueles que trabalham e criam os produtos, e não para o lucro de alguns. No entanto, consideram que uma revolução socialista precisa necessariamente ser uma revolução feminista e antirracista, pois só assim há libertação. Para estas feministas, é preciso desenvolver uma compreensão das relações de classe que leve em conta a posição radicalmente subalterna na qual a classe específica das mulheres negras se encontra. É preciso "articular a situação real de classe dessas pessoas, que não são meramente trabalhadoras sem raça e sem sexo, mas para quem as opressões racial e sexual são determinantes significativos para suas vidas laborais e econômicas" (p. 201).

Como aponta Curiel (2007), o coletivo Combahee River introduz também uma análise política da heterossexualidade que permite elaborar uma nova significação da descolonização dos corpos e da sexualidade das mulheres. Nesta perspectiva, é também deflagrado o caráter de resistência política do lesbianismo. Clarke (1988) aponta:

\begin{abstract}
Onde quer que nós, lésbicas, nos encontremos ao longo deste muito difundido continuo político/social, precisamos saber que a instituição da heterossexualidade é um costume que quase não morre e que através dela as instituições de homens supermachistas garantem sua própria perpetuação e controle sobre nós. É útil que nossos colonizadores confinem nossos corpos e nos afastem de nossos próprios processos vitais, assim como foi útil para os europeus escravizarem os africanos e destruírem toda a memória de uma liberdade e autodeterminação anteriores. Assim como o fundamento do capitalismo ocidental dependia do tráfico de escravos no Atlântico Norte, o princípio da dominação patriarcal é sustentado pela sujeição das mulheres através da heterossexualidade compulsória (pp. 100101 apud CURIEL, 2007, p. 96, tradução nossa ${ }^{18}$ ).
\end{abstract}

\footnotetext{
${ }^{18}$ Donde quiera que nosotras como lesbianas nos encontremos a lo largo de este muy generalizado continuo político/social, tenemos que saber que la institución de la heterosexualidad es una costumbre que difícilmente muere y que a través de ella las instituciones de hombres supermachistas asegura su propia perpetuidad y control sobre nosotras. Es provechoso para nuestros colonizadores confinar nuestros cuerpos y alienarnos de nuestros propios procesos vitales, así como fue provechoso para los europeos esclavizar al africano y destruir toda memoria de una previa libertad y autodeterminación. Así como la fundación del capitalismo occidental dependió del tráfico de esclavos en el Atlántico Norte, lo sistema de dominación patriarcal se sostiene por la sujeción de las mujeres através de una heterosexualidad obligada (Clarke, 1988, p. 100-101).
} 
A noção de "heterossexualidade compulsória" foi formulada pela escritora feminista norte-americana Adrienne Rich, em 1980, para dar um sentido político a heterossexualidade, afirmando que ela atua em todas as relações sociais e não apenas nas práticas sexuais. Depois foi aprofundada pela feminista materialista francesa Monique Wittig, em 1982, que a analisou como um regime político, trazendo o aspecto importante da reavaliação e transformação conceitual como ação política, como aprofundaremos mais adiante.

Paralelamente aos movimentos das feministas negras, Curiel (2007) destaca ainda o surgimento de teorias e movimentos feministas mexicanos que de seus lugares denunciam as diversas opressões, propondo uma política de identidade híbrida e mestiça. Nesse movimento, pode-se destacar a perspectiva trazida por Gloria Anzaldúa (1987) e seu conceito de fronteira [borderlands] ${ }^{19}$, que coloca em questão o nacionalismo mexicano e o racismo nortemamericano, bem como o feminismo criado pelas mulheres brancas do Norte e ainda o heterossexismo na estrutura do contexto global do capitalismo.

Anzaldúa foi pioneira no que hoje se denomina "pensamento fronteiriço", que deflagra as limitações de identidades essencialistas e autênticas. Ela defende que a identidade mestiça romperia com os binarismos sexuais e a imposição de um culturalismo que fixa as mulheres em determinadas posições e funções para mantê-las subordinadas. Como feminista e lésbica, ela criticou tanto o imperialismo norteamericano quanto certas tradições de sua cultura originária, que a subordinavam.

Mas, como ressalta Curiel (2007), a identidade mestiça defendia por Anzaldúa tem esse sentido no contexto norteamericano. Nos Estados Unidos, se reconhecer subalterna e se reivindicar "latina" constitui um ato de resistência. Mas na América Latina e no Caribe, esta identidade ganha outro sentido, já que nessas regiões, a mestiçagem foi um dos mecanismos ideológicos que construíram os Estado-Nação. Na história do Brasil, por exemplo, esse processo se explicita através da criação das políticas estatais de branqueamento da população do final

\footnotetext{
${ }^{19}$ Cabe destacar que as feministas mexicanas utilizam um estilo bilíngue, denominado spanglish, que tem o caráter político de romper com a "pureza gramatical" e cruzar fronteiras geopolíticas, literárias e conceituais.
} 
do século XIX até meados do XX (SCHUCMAN, 2014; SOARES E ZAMORA, 2018).

Dessa maneira, Curiel $(2009,2016)$ reconhece a extrema importância das teorias e práticas construídas pelas feministas negras norte-americanas e as feministas mexicanas e suas contribuições imprescindíveis para a formação de uma perspectiva crítica em relação ao feminismo. A autora ressalta ainda a importância das políticas identitárias no aumento da autoestima individual e coletiva das mulheres negras e não brancas, bem como sua fundamental contribuição para a mobilização, as trocas de experiências, a recuperação de uma ancestralidade tomada de assalto pelo racismo e pelo sexismo desde a colonização, o questionamento de um padrão estético ocidentalizado dos corpos o que possibilitou a construção, legitimação e valorização de uma estética negra a partir de suas próprias referências e experiências.

O Black Feminism, o feminismo chicano nos Estados Unidos são definitivamente duas das propostas mais radicais produzidas contra os efeitos do colonialismo desde uma visão materialista, antirracista e antissexista, que muito contribui às vozes críticas na América Latina e no Caribe e devem ser convertidos referências importante para a teoria e prática pós-colonial (CURIEL, 2007, p. 98, tradução $\operatorname{nossa}^{20}$.

Mas buscando construir uma abordagem autónoma, as feministas decoloniais latino-americanas, além de tomarem como referência os pensamentos e práticas desenvolvidos pelas feministas negras e não brancas de outras regiões, retomam também as contribuições de pensadores latinoamericanos e caribenhos ligados ao projeto decolonial. Isto porque, tais projetos propõem uma nova compreensão para as experiências vividas pelas populações das nossas regiões "que implica uma releitura da história, novas filosofias, novas epistemologias que ajudam a uma ação política mais descolonizadora e transformadora" (CURIEL, 2016, p. 80, tradução nossa ${ }^{21}$ ).

\footnotetext{
20 "El Black Feminism y el feminismo chicano en Estados Unidos han sido definitivamente dos de las propuestas más radicales que se han producido contra los efectos del colonialismo desde una visión materialista, antirracista y antisexista, que mucho ha aportado a las voces críticas en América Latina y el Caribe, y que deben convertirse en referencia importante para la teoría y práctica poscolonial".

21،que implica una relectura de la historia, nuevas filosofías, nuevas epistemologías que ayudan a una acción política más descolonizadora y transformadora"
} 
Nessa perspectiva, falar da colonialidade do poder e seus efeitos sobre as mulheres da América Latina e do Caribe é necessariamente falar sobre as sequelas do colonialismo e suas permanências na modernidade e na maneira como se constituíram os Estado-Nações latino-americanos e caribenhos. Um processo que se deu tendo a homogeneização racista como proposta nacional através da ideologia da mestiçagem atrelada a ideia de "melhorar a raça".

Pensadoras feministas negras brasileiras como a antropóloga Lélia Gonzalez e a filósofa Sueli Carneiro trazem análises importantes acerca das especificidades que o sistema colonial escravocrata instaurado no Brasil, bem como as políticas criadas no pós-abolição, impuseram em termos de opressão as vidas das mulheres negras e não brancas em nosso país. Estas autoras, em conjunto com outras/os importantes pensadores/as brasileiros/as, denunciam o mito da democracia racial, o ideal de branqueamento e as políticas estatais de branqueamento como constitutivos de uma ideologia de dominação que mantém até os dias atuais desigualdades sociais e econômicas entre brancos, indígenas e negros (NASCIMENTO, 1978; GONZALEZ, 1984; CARNEIRO, 2011, 2019; SCHUCMAN, 2014; SOARES E ZAMORA, 2019). Como feministas, aprofundam suas análises na compreensão de como tal ideologia se instituiu a partir da exploração e violação das mulheres negras e indígenas, utilizadas como objetos sexuais do homem branco e reprodutoras dos chamados "mestiços", com a finalidade de "melhorar a raça", como aprofundaremos adiante.

Os movimentos realizados pelas mulheres indígenas também tem construído uma perspectiva crítica pós-colonial. Como aponta Curiel (2007), esse movimento surge dentro dos movimentos mistos a partir dos anos setenta e vai ganhando força nos anos seguintes. As feministas indígenas questionam as relações patriarcais e a subordinação das mulheres nas sociedades latinoamericanas e dentro de suas próprias comunidades e tradições. Suas lutas políticas se distribuem em frentes que exigem o reconhecimento de uma história de colonização, o reconhecimento de sua cultura, a distribuição econômica de maneira justa, bem como denunciam o racismo e a segregação operados pelo Estado. E junto a isto, colocam em questão o patriarcado indígena, buscando a autodeterminação como mulheres e como povo. 
Tomando essas referências, a perspectiva feminista decolonial compreende que o que esta em jogo, como apontam Pires e Gill (2019), é “como articular, analiticamente e não apenas de forma descritiva, as maneiras pelas quais gênero, raça, classe e sexualidade explicam os tipos de desigualdades e violências que compõem as sociedades pós-coloniais" (p. 196, tradução nossa ${ }^{22}$ ). Nesta proposta, o conceito de imbricação [imbricación] ${ }^{23}$ (CURIEL, 2009; 2016) passa a ser utilizado, ao invés da interseccionalidade. Isto porque, como aponta Curiel (2009), ele melhor evidencia a dependência existente "entre as diferentes categorias e a implicação articulada de diferentes sistemas de dominação e opressão na vida de muitas mulheres" (pp. 39-40, tradução nossa ${ }^{24}$ ). Para ela:

Compreender a imbricação das opressões não se trata de colocar categorias que conformam uma somatória de experiências, ou uma intersecção de categorias analíticas (CRENSHAW, 1993), mas de entender como estas tem atravessado historicamente nossa região desde o colonialismo até a colonialidade contemporânea e como tem se expressado em determinados sujeitos que não tem privilégios de raça, classe, sexo e sexualidade, como são as mulheres negras, indígenas e campesinas da região (CURIEL, 2016, p. 80, tradução nossa ${ }^{25}$ ).

A substituição da noção de interseccionalidade pela de imbricação se da, portanto, no sentido de explicitar que as estruturas de raça, classe, sexo e sexualidade estão cada uma inscrita nas outras, sendo constitutivas de e pelas outras. Para o feminismo decolonial, ter clareza dessa dinâmica é imprescindível para pensamos as condições das mulheres na modernidade/colonialidade em suas especificidades.

\footnotetext{
22 "how to articulate, analytically and notmerely in descriptiveform, theways in whichgender, race, class and sexualityexplainthekinds of inequalities and violencesthatcompose postcolonialsocieties".

${ }^{23}$ Imbricar: O dicionário Aulete define imbricar como sobrepor (coisas, ideias, etc.), numa das partes ou lados.

24 "entre las distintas categorías y la implicación articulada de distintos sistemas de dominación y opresión en la vida de muchas mujeres".

${ }^{25}$ Comprender la imbricación de las opresiones no se trata de colocar categorías que conforman una sumatoria de experiencias, o una intersección de categorías analíticas (CRENSHAW, 1993), se trata de entender cómo estas han atravesado históricamente nuestra región desde el colonialismo hasta al colonialidad contemporánea y como se ha expresado en ciertos sujetos que no han tenido privilegios de raza, clase, sexo y sexualidad, como son las mujeres negras, indígenas y campesinas de la región.
} 


\section{CAPÍTULO 3. SISTEMA DE GÊNERO MODERNO/COLONIAL, SUBALTERNIZAÇÃO DAS MULHERES E LUTAS FEMINISTAS}

\section{1. "Caça às bruxas" e patriarcado moderno/colonial}

É na "transição" 26 do feudalismo para o capitalismo, que a filósofa italiana Silvia Federici (2017) identifica o período em que o patriarcado europeu toma formas extremas de misoginia e violência. Voltando-se especialmente para a análise das motivações e acontecimentos decorrentes da "caça às bruxas", a autora afirma que este movimento não aconteceu somente por razões religiosas. Segundo ela, há uma estreita relação entre a perseguição e assassinato de mulheres e a exploração de seus corpos pela instituição da lógica capitalista, não sendo possível compreender as transformações trazidas pelo capitalismo sem levar em consideração o papel social das mulheres neste período - suas lutas coletivas, sua vida comunal e a imposição de um controle estatal sobre seus corpos.

Para Federici, a "campanha terrorista patrocinada pelo Estado" (p. 118), que foi a grande caça às bruxas dos séculos XVI e XVII, teve um papel fundamental na expulsão do campesinato europeu das terras anteriormente comunais e, consequentemente, em sua derrota. Segundo a autora, ela foi um dos mais importantes acontecimentos do desenvolvimento da sociedade capitalista e da formação do proletariado moderno, visto que:

[...] debilitou a capacidade de resistência do campesinato europeu frente ao ataque lançado pela aristocracia latifundiária e pelo Estado, em uma época na qual a comunidade camponesa já começava a se desintegrar sob o impacto combinado da privatização da terra, do aumento dos impostos e da extensão do controle estatal sobre todos os aspectos da vida social. A caça às bruxas aprofundou a divisão entre mulheres e homens, inculcou nos homens o medo do poder das mulheres e destruiu um universo de práticas, crenças e sujeitos sociais cuja existência era incomparável em disciplina do trabalho capitalista, redefinindo assim os principais elementos de reprodução social. Neste sentido, [...] a caça às bruxas foi um elemento essencial da acumulação primitiva e da "transição" ao capitalismo (2017, p. 294).

\footnotetext{
${ }^{26}$ Federici considera que falar em "transição para o capitalismo" é uma ficção, visto que o termo "transição" sugere um desenvolvimento histórico linear quando na verdade, estamos falando de um dos períodos mais violentos e descontínuos da história mundial. Para a autora, este termo "é incapaz de evocar as mudanças que abriram o caminho para a chegada do capitalismo e das forças que conformaram essas mudanças" (p. 116-117). Desta maneira, compreende que seu uso só pode ser feito em um sentido temporal.
} 
É no cenário de uma sociedade devastada pela peste negra e, em sequência, no século $\mathrm{XV}$, pela profunda transformação nas relações de classe que promoveram uma reorganização capitalista da vida social e econômica europeia, que a "caça as bruxas" se desenvolve. Período em que as mulheres passam a ser sistematicamente perseguidas.

De acordo com Federici, a principal diferença entre essa perseguição e a perseguição sofrida pelos hereges, que também fizeram resistência as mudanças sociais em período anterior, foi a de que a bruxaria era considerada um crime feminino - " $80 \%$ das pessoas julgadas e executadas na Europa nos séculos XVI e XVII pelo crime de bruxaria eram mulheres” (FEDERICI, 2017, p. 233).

De acordo com Rosa Marie Muraro (2015), já no fim do século XV e começo do século XVI, houve milhares e milhares de execuções. Em geral, as "bruxas" eram queimadas vivas na fogueira. Ela aponta que há estimativas de que em certas cidades 600 mulheres foram assassinadas por ano. E, segundo a autora, há ainda outros cálculos que mostram que o número mínimo de mulheres queimadas vivas é de cem mil, sendo a maioria delas camponesas.

$\mathrm{Na}$ caça às bruxas, as acusações de perversão sexual e infanticídio tiveram um papel central, vindo acompanhadas pela demonização das práticas contraceptivas. Não por acaso, muitas mulheres acusadas de bruxaria eram parteiras ou mulheres que detinham grande conhecimento sobre o controle reprodutivo feminino. Para Federici, isso demonstra uma ligação entre a perseguição às bruxas e uma preocupação profunda, entre estadistas e economistas europeus, com a questão da reprodução. Uma preocupação, segundo ela, fundada na questão da extensão da força de trabalho naquela época.

De acordo com Federici, a centralidade das acusações voltadas a sexualidade e reprodução revela um movimento de criminalização do controle da natalidade e "de colocar o corpo feminino - o útero - a serviço do aumento da população e da acumulação de força de trabalho" (2017, p. 326). Para a autora, foi uma classe política preocupada com a diminuição da população que promoveu a caça às bruxas. Ela argumenta que, assim como as terras comunais do campesinato foram cerceadas, "a caça às bruxas expropriou os corpos das mulheres, os quais foram assim 'liberados' de qualquer obstáculo que lhes 
impedisse de funcionar como máquinas para reproduzir mão de obra" (p. 330).Destruindo os métodos contraceptivos, denunciando-os como instrumentos diabólicos, o controle do Estado sobre o corpo das mulheres foi institucionalizado, estabelecendo o pré-requisito primordial para sua subordinação à reprodução da força de trabalho.

Federici compreende que a caça às bruxas se configura assim como uma guerra contra as mulheres - uma tentativa de degradá-las, demonizá-las e destruir seu poder social. Para ela, é nas câmaras de tortura e fogueiras, que, concomitantemente, se engendraram os ideais burgueses de feminilidade e domesticidade, afirmando que no plano ideológico há

estreita correspondência entre a imagem degradada da mulher, forjada pelos demonólogos, e a imagem da feminilidade construída pelos debates da época sobre a "natureza dos sexos", que canonizava uma mulher estereotipada, fraca do corpo e da mente e biologicamente inclinada ao mal, o que efetivamente servia para justificar o controle masculino sobre as mulheres e a nova ordem patriarcal (2017, p. 335).

As principais teses cristãs que permitiram esse expurgo do feminino foram, segundo Muraro (2015), as de Malleus Maleficarum ${ }^{27}$, que, em linhas gerais, determinavam que o mal e o domínio do Demônio se dão através principalmente do corpo; que este domínio vem através do controle e da manipulação dos atos sexuais, sendo a sexualidade o ponto mais vulnerável dos seres humanos; que, como as mulheres estão essencialmente ligadas à sexualidade, elas se tornam as agentes por excelência do Demônio, sendo a primeira e maior característica, que dá todo o poder às feiticeiras, é copular com o Demônio; que uma vez obtida a intimidade com o Demônio, as feiticeiras são capazes de desencadear todos os males, especialmente a impotência masculina, a impossibilidade de livrar-se de paixões desordenadas, abortos, oferendas de crianças a Satanás, estrago das colheitas, doenças nos animais etc; e, por fim, que estes pecados eram mais hediondos do que os próprios pecados de Lúcifer, porque agora as bruxas pecam contra Deus e o Redentor (Cristo), sendo este crime imperdoável e, portanto, só passível de ser resgatado com a tortura e a morte.

\footnotetext{
${ }^{27}$ Livro lançado em 1484, escrito pelos teólogos e inquisidores dominicanos, Jacob Sprenger e Heinrich Kramer, destinado a ajudar inquisidores a identificar e processar as acusadas de bruxaria.
} 
Federici aponta que, nesse momento, a visão renascentista da relação entre o diabo e o mago, que retratava o diabo como um ser subordinado, obediente ao seu senhor, é invertida na relação de poder entre o diabo e bruxa. A mulher bruxa é a criada. O diabo é ao mesmo tempo seu dono e senhor, cafetão e marido. É ele quem busca a bruxa para torna-la sua serva, imprimindo nela sua marca (um exemplo clássico da relação senhor/escravo). Além disso, “em uma clara previsão de destino matrimonial das mulheres, a caça às bruxas introduzia um só diabo, em vez de uma multidão de diabos que pode ser encontrada no mundo medieval e renascentista" (FEDERICI, 2017, p. 337).

Tais representações demonstravam a grande preocupação dos caçadores de bruxas com a afirmação da supremacia masculina. Mesmo quando as mulheres se rebelavam contra as leis humanas e divinas, eram retratadas como subservientes a um homem, sendo o "pacto com o diabo" representado como um contrato de casamento pervertido.

Em tese, todas as mulheres eram bruxas em potencial. Para Federici, um dos principais efeitos da propaganda e terror foi plantar entre os homens as sementes de uma profunda alienação psicológica com relação as mulheres, o que abalou fortemente a solidariedade de classe, minando seu próprio poder coletivo.

Assim como atualmente, ao reprimir as mulheres, as classes dominantes reprimiam de forma ainda mais eficaz o proletariado como um todo. Instigavam os homens que foram expropriados, empobrecidos e criminalizados a culpar a bruxa castradora pela sua desgraça e a enxergar o poder que as mulheres tinham ganhado contra as autoridades como um poder que as mulheres utilizariam contra eles. Todos os medos profundamente arraigados que os homens nutriam em relação às mulheres (principalmente devido à propaganda misógina da Igreja) foram mobilizados nesse contexto. As mulheres não só foram acusadas de tornar os homens impotentes, mas também sua sexualidade foi transformada num objeto de temor, uma força perigosa, demoníaca (FEDERICI, 2017, p. 341).

As bruxas eram, ao mesmo tempo acusadas de deixarem homens impotentes e neles alimentar uma excessiva paixão erótica. Para Federici, no entanto, a simultaneidade dessas acusações estava longe de ser uma contradição. Isto porque, no novo código patriarcal que se estabelecia concomitantemente à caça às bruxas, a impotência sexual era a manifestação física do desgaste da autoridade masculina sobre as mulheres, não havendo do ponto de vista "funcional" diferença significativa entre um homem castrado e um homem apaixonado. Para os demonólogos, ambos os estados inspiravam desconfiança. 
Eles acreditavam que, de uma maneira ou de outra, se as mulheres pudessem exercer tanto poder sobre os homens, "seria impossível colocar em prática o tipo de família exigida pelo senso comum da burguesia da época - inspirada no Estado, com o marido como rei e a mulher subordinada à sua vontade, devota à administração do lar de maneira abnegada” (p. 341).

Nessa lógica, a paixão sexual destruía tanto a autoridade dos homens sobre as mulheres quanto a capacidade de um homem de governar a si mesmo, o que o fazia "perder a cabeça onde a filosofia cartesiana situaria a fonte da razão" (FEDERICI, 2017, p. 343). Portanto, a sexualidade feminina representava uma ameaça à ordem social, necessitando ser dominada, não apenas através da morte na fogueira, mas por meio de tortura, de intensos e detalhados interrogatórios que mesclavam "exorcismo sexual e estupro psicológico" (idem).

Os séculos XVI e XVII inauguravam assim, para as mulheres europeias, uma era de intensa repressão sexual em que sua sexualidade passava a ser definida pela censura e proibição. Para Federici, "explosão discursiva" sobre o sexo, que Foucault (1978 apud FEDERICI, 2017) detectou nesta época, não foi em nenhum outro lugar mais veementemente exibida do que nas câmaras de tortura da caça às bruxas. Mas, na perspectiva da autora, isso nada tem a ver uma excitação mútua fluindo entre a mulher e seu confessor, tal como imaginara Foucault. Era sob torturas diversas que as supostas bruxas eram forçadas a explicar como haviam sido possuídas pelo demônio, seus sentimentos, pensamentos e sensações durante a penetração - em um momento em que experimentavam dores profundas e enlouquecedoras.

Assim, para Federici, não é possível, em nenhuma hipótese, presumir que a orgia de palavras que as mulheres eram forçadas a dizer mediante torturas diversas as excitava ou reorientava, por sublimação linguística, seu desejo. Para ela:

No caso da caça às bruxas - que Foucault ignora de forma surpreendente em sua História da sexualidade (Foucault, 1978, vol. I) -, o "discurso interminável sobre o "sexo" não foi desencadeado como uma alternativa a repressão, mas a serviço da repressão, da censura, da rejeição. Certamente, podemos dizer que a linguagem da caça às bruxas "produziu" a mulher como uma espécie diferente, um ser sui generis, mais carnal e pervertido por natureza. [...] devemos reconhecer o caráter destrutivo deste processo, que também demonstra os limites de uma "história da sexualidade" genérica, como a proposta por Foucault, que 
trata a sexualidade a partir da perspectiva de um sujeito indiferenciado, de gênero neutro, e como uma atividade que supostamente tem as mesmas consequências para homens e mulheres (pp. 344-345).

Além de condenar a sexualidade feminina como fonte do mal, a caça às bruxas representou a principal via de implementação de uma ampla reestruturação da vida sexual. Ajustada à nova disciplina capitalista do trabalho, essa reestruturação criminalizava atividades sexuais que ameaçassem a procriação e a transmissão da propriedade no interior da família ou que reduzissem o tempo e a energia disponíveis para o trabalho.

Nesse período, a Europa vivia um prolongamento da crise de acumulação por mais de um século. Como aponta Federici, não apenas a economia feudal, como também sua suposta "evolução" para a sociedade capitalista se viram condenadas, visto que ao mesmo tempo que a autossuficiência e o novo regime de salários elevados permitiam a "riqueza do povo", eles excluíam a possibilidade da riqueza capitalista.

É em resposta a essa crise que a classe dominante europeia lança a ofensiva global. Sustentada por uma violência extrema, ela tinha como objetivos principais a apropriação de novas fontes de riqueza, a expansão de sua base econômica e a cooptação de novos trabalhadores.

As análises de Federici sobre esse processo se aproximam das realizadas pelas pensadoras e pensadores decoloniais, considerando que é através do colonialismo que se estabelecem as bases do sistema capitalista mundial e que, portanto, este não seria possível sem aquele. Em termos de exploração e subalternização de classe, sexo e raça, ela enfatiza que, para a instauração deste sistema, mais do que a expropriação dos meios de subsistência dos trabalhadores europeus e a escravização dos povos da América e da África nas minas e nas plantações do Novo Mundo, para a formação de um proletariado mundial e "acumulado", foi necessário tanto transformar o corpo em uma máquina de trabalho quanto sujeitar as mulheres para a reprodução da força de trabalho. Neste sentido, a acumulação primitiva não foi meramente uma acumulação e uma concentração de trabalhadores exploráveis e de capital, mas ainda uma acumulação de diferenças e divisões dentro da classe trabalhadora, em que hierarquias sexuais, raciais e etárias foram fundamentais. 
Federici considera que existe uma continuidade entre a dominação colonial das populações do chamado "Novo Mundo" e a das populações da Europa, em especial as mulheres, durante a "transição" feudalismo-capitalismo. Ela argumenta que, embora as diferenças não possam ser subestimadas, em ambos os casos, houve a expulsão pela força de populações inteiras de suas terras e um grande empobrecimento, além de campanhas de "cristianização", que visaram acabar com a autonomia das pessoas e fragilizar imensamente suas relações comunais.

Há, segundo Federici, no decorrer do século XVII, um crescente intercâmbio entre a ideologia da bruxaria e a ideologia racista colonial. A figura do diabo era representada pela de um homem negro e os negros eram tratados como diabos. Um desejo e uma potência sexual "anormais" eram considerados uma marca característica do diabólico. Para ela, a definição da negritude e da feminilidade como marcas da bestialidade e da irracionalidade legitimava a exclusão das mulheres e dos homens nas colônias "do contrato social implícito no salário, com a consequente naturalização de sua exploração" (p. 360).

Uma das principais estratégias de desarticulação e desumanização das populações subalternizadas no colonialismo foi proibir e/ou destruir seus símbolos, suas raízes históricas, sua relação com a terra e a natureza, incluindo a intensidade espiritual nela presente (QUIJANO, 1992; WALSH, 2009; NASCIMENTO, 1978; LERNER, 2019; FEDERICI, 2017). Um processo que ocorreu por meio da tortura, das denúncias anônimas e das humilhações públicas e impactou de forma muito negativa nas alianças, nas amizades, na fé dos povos em seus deuses e na coletividade de seus cultos, que se tornaram cada vez mais individuais e secretos.

De acordo com Federici (2017), a destruição dos símbolos e deuses das culturas autóctones foi acompanhada por verdadeiras caças às bruxas, convertendo as mulheres em alvo particular. Esta conversão não aconteceu por acaso. As mulheres das populações subalternizadas foram as que defenderam mais firmemente seu tradicional modo de existência, se opondo fortemente à nova estrutura de poder - provavelmente porque eram também as mais prejudicadas por ela. Como aponta a autora, a bagagem misógina trazida pelos colonizadores 
reestruturou em favor dos homens a economia e o poder político, o que colocou as mulheres dos grupos colonizados em uma situação especialmente difícil.

\subsection{Instauração do Sistema de Gênero Moderno/Colonial radicalização da condição subalterna das mulheres colonizadas}

O impacto extremamente negativo das relações de gênero estabelecidas pela colonização na vida comunal das sociedades pré-coloniais, em especial para as mulheres, vem sendo analisado por feministas decoloniais (LUGONES, 2008; SEGATO, 2014; GALINDO, 2015). Por diferentes caminhos, estas pensadoras buscam compreender como o processo de reestruturação política e econômica em favor dos homens instituído pela colonização radicalizou a condição de subalternidade das mulheres colonizadas, instaurando o que Lugones (2008) chamou de "Sistema de Gênero Moderno/Colonial".

No clássico texto "Colonialidade e Gênero", que inaugura a proposta do feminismo decolonial, Lugones (2008) desenvolve o pensamento de que tanto a ideia de raça quanto a de gênero se produzem simultaneamente no processo de conquista e colonização. A partir desta perspectiva, ela propõe uma expansão do sentido da matriz colonial de poder proposta por Quijano, afirmando que o que existe nas sociedades que sofreram a violência colonial é um entrelaçamento dos componentes gênero, raça, sexualidade e trabalho que incidem inseparavelmente na vida cotidiana.

Introduzindo a noção de "colonialidade do gênero", Lugones explica a imposição colonial de um tipo de relação hierárquica baseada na "diferença sexual", afirmando assim que naturalização das "diferenças sexuais" é produto do uso moderno da ciência. Para ela, a compreensão desse processo afeta profundamente o estudo das sociedades pré-colombianas, pois coloca em questão o uso do conceito "gênero" como parte da organização social dessas sociedades.

Tomando como principais referências para sua teoria os estudos de Oyéronké Oyewùmi (1997 apud LUGONES, 2008) e de Paula Gunn Allen (1986/1992 apud LUGONES, 2008), Lugones desenvolve o pensamento de que o gênero, assim como a raça, é uma poderosa ficção da modernidade/colonialidade. 
Ela ressalta o fato de tanto os estudos de Oyewùmi quanto o de Allen se desenvolvem tendo como interesse comum entender a colaboração entre homens colonizados (indígenas e negros) e homens colonizadores (brancos) para enfraquecer o poder das mulheres. Compartilhando deste interesse, a autora aponta ainda que tal análise nos possibilita compreender nos dias atuais a indiferença dos homens às lutas das mulheres colonizadas contra as múltiplas formas de violência que incidem sobre elas e suas comunidades subalternizadas.

De acordo com Lugones, os estudos de Oyewùmi apresentam a compreensão de que a associação entre anatomia e gênero que designa o que é uma "mulher", parte da oposição binária e hierárquica introduzida pela colônia. Segundo ela, a ideia de que as mulheres são definidas em relação aos homens, que representam a norma, e que não possuem poder e não podem participar da arena pública por não possuírem um pênis, não existia para as fêmeas Yorubas antes da colonização.

Oyewùmi argumenta que, na sociedade Yoruba, não havia um sistema de gênero institucionalizado. Para ela, o gênero adquiriu importância nos estudos Yoruba por uma questão de tradução para o inglês - para se encaixar no modelo Ocidental de separação entre corpo e razão. Assim, incluir o gênero como um princípio de organização social da sociedade Yoruba é, para a autora, mais um caso de dominação Ocidental sobre a documentação e interpretação do mundo.

A imposição do sistema de estado Europeu, com sua concomitante (?) maquinaria burocrática e legal, é o legado mais duradouro da dominação colonial europeia em África. A exclusão das mulheres da recentemente criada esfera pública colonial é uma tradição que foi exportada à África durante este período... O mesmo processo que as categorizou e reduziu de fêmeas à "mulheres" as desqualificou para papéis de liderança... A emergência da mulher como uma categoria reconhecível, definida anatomicamente e subordinada ao homem em todo tipo de situação, resultou, em parte, da imposição de um Estado colonial patriarcal. Para as mulheres, a colonização foi um processo dual de inferiorização racial e subordinação de gênero. Uma das primeiras conquistas do Estado colonial foi a criação de "mulheres" como categoria. Portanto, não me surpreende que para o governo colonial fosse inimaginável reconhecer as fêmeas como líderes entre as pessoas que colonizaram, incluindo os Yoruba... De certo modo, a transformação do poder do Estado em poder masculino se conquistou excluindo as mulheres das estruturas estatais. Isto se manteve em um profundo contraste com a organização do Estado Yoruba, na qual o poder não estava determinado 
por gênero (1997, pp. 123-125 apud LUGONES, 2008, pp. 87-88, tradução minha) $)^{28}$.

Oyewùmi reconhece assim a imposição das raças (que relega os negros africanos a inferiorização) e a subalternização das fêmeas das sociedades précoloniais como os dois processos cruciais para a colonização, sendo a inferiorização destas estendida amplamente, "abarcando a exclusão das posições de liderança até a perda da propriedade sobre a terra e outros importantes espaços econômicos" (LUGONES, 2008, p. 88) ${ }^{29}$. A autora analisa que os machos Yoruba aceitaram o sistema de gênero imposto pelos colonizadores, compactuando assim com a inferiorização das fêmeas. Para ela, essa colaboração entre os machos colonizados e os colonizadores europeus contra as fêmeas colonizadas explicaria em certa medida a indiferença dos homens colonizados à violência contra as elas percebida ainda hoje.

Paula Gunn Allen, outra referência importante das análises feitas por Lugones (2008), caracteriza muitas das tribos de Americanos Nativos como ginecocráticas, isto é, governadas por fêmeas. Allen enfatiza a importância do espiritual em todos os aspectos da vida indígena, afirmando assim que havia uma intersubjetividade muito diferente da colonialidade do saber na modernidade, no modo de produzir conhecimento. Para esta autora, muitas tribos indígenas americanas compreendem a força feminina como primária do universo e essa compreensão autoriza todas as atividades tribais.

Nessa perspectiva, Allen afirma que a inferiorização das mulheres indígenas está fortemente ligada à dominação e transformação da vida das

\footnotetext{
28 "La imposición del sistema de estado Europeo, con su concomitante (i) maquinaria burocrática y legal, es el legado más duradero de la dominación colonial Europea en África. La exclusión de las mujeres de la recientemente creada esfera pública colonial es una tradición que fue exportada al África durante este periodo... El mismo proceso que las categorizó y redujo de hembras a «mujeres» las descalificó para roles de liderazgo... La emergencia de la mujer como una categoria reconocible, definida anatómicamente y subordinada al hombre en todo tipo de situación, resultó, en parte, de la imposición de un Estado colonial patriarcal. Para las mujeres, la colonización fue un proceso dual de inferiorización racial y subordinación de género. Uno de los primeros logros del Estado colonial fue la creación de «mujeres» como categoría. Por lo tanto no es sorprendente que para el gobierno colonial haya resultado inimaginable el reconocer a hembras como líderes entre las gentes que colonizaron, incluyendo los Yoruba... A un nivel, la transformación del poder del Estado en poder masculino se logró excluyendo a las mujeres de las estructuras estatales. Esto se mantuvo en un profundo contraste con la organización del Estado Yoruba, en la cual el poder no estaba determinado por el género"

29 "abarcando desde la exclusión en roles de liderazgo hasta la pérdida de la propiedad sobre la tierra y otros importantes espacios económicos"
} 
comunidades pela colonização, sendo a destruição das ginecocracias crucial para exterminar as populações pela fome, doenças e a destruição de suas estruturas econômicas, espirituais e sociais. Para ela, a readaptação de versões tribais arcaicas (história, costumes, instituições e tradições) "aumenta a probabilidade de que sejam incorporadas dentro das tradições espirituais e populares das tribos revisões patriarcais da vida tribal, distorcidas ou simplesmente inventadas por patriarcas que não são índios e índios que se "patriarcalizaram" (ALLEN, 1986/1992: 42 apud LUGONES, 2008, p. 90).

De acordo com Allen, entre as características da sociedade indígena condenada à destruição estão a estrutura social bilateral complementar, a compreensão do gênero e a distribuição econômica que costumava seguir um sistema de reciprocidade.

Os dois dados da estrutura social complementar incluíam uma chefa interna e um chefe externo. A chefa interna presidia a tribo, a vila ou o grupo, ocupando-se de manter a harmonia e administrar assuntos internos. O chefe macho vermelho, presidia as mediações entre a tribo e os que não pertenciam a ela (Allen, 1986/1992:18). O gênero não foi entendido antes de tudo em termos biológicos. A maioria dos indivíduos se encaixava dentro dos papéis de gênero tribais "com base a propensão, inclinação e temperamento" (LUGONES, 2008, p. 90, tradução nossa ${ }^{30}$.

Para Lugones, o trabalho de Allen nos possibilita perceber que na colonialidade a produção de conhecimento e todos os níveis da concepção da realidade são "engenerizados" (LUGONES, 2008, p. 92). Além disso, seu pensamento também contribui para o questionamento da biologia e sua incidência na construção das diferenças de gênero modernas/coloniais.

Outras feministas latino-americanas vem pensando o sistema de gênero moderno/colonial, partindo de uma perspectiva que se diferencia da apresentada por Oyewùmi, Allen e Lugones no que diz respeito a afirmação de que relações de gênero pautadas em uma "diferença sexual" inexistiam no mundo pré-colonial. Dentre estas, encontram-se as feministas Rita Segato, antropóloga argentina e Maria Galindo, psicóloga boliviana.

\footnotetext{
30“Los dos lados de la estructura social complementaria incluían una jefa interna y un jefe externo. La jefa interna presidía la tribu, la villa o el grupo, ocupándose de mantener la armonía y administrar asuntos internos. El jefe macho rojo, presidía las mediaciones entre la tribu y los que no pertenecían a ella (Allen, 1986/1992:18). El género no fue entendido ante todo en términos biológicos. La mayoría de los individuos encajaban dentro de los roles de género tribales «en base a propensión, inclinación y temperamento".
} 
Segato (2014), em seus estudos, afirma que uma gama de evidências históricas e relatos etnográficos apontam para existência de organizações patriarcais, estruturadas pela hierarquia sexual, nas sociedades autóctones no período anterior a invasão. No entanto, ela considera que existem diferenças significativas entre as relações estabelecidas no "mundo aldeia" (pré-invasão), especialmente no que diz respeito a mobilidade entre as posições que mulheres e homens ocupavam nessas sociedades - que era muito maior do que nas organizações ocidentais modernas. Neste sentido, para a autora podemos afirmar que a aproximação do gênero moderno colonial foi, para a aldeia, fatal (SEGATO, 2014).

De acordo com Segato, a partir do processo de colonização, há uma transformação do patriarcado já identificado no mundo-aldeia, no sentido de uma intensificação. Para ela, esse processo ocorre a partir de uma intervenção na estrutura das relações da aldeia que as captura e reorganiza a partir de dentro. $\mathrm{Ou}$ seja, a modernidade colonial intervém mantendo a aparência de continuidade, preservando nomenclaturas, mas transformando os sentidos, que passam a ser interpretados e governados à luz da nova ordem moderna e suas normas.

Segato utiliza como um exemplo disso o que acontece quando ela chega para conversar com mulheres indígenas sobre os problemas crescentes de violência contra as mulheres em aldeias brasileiras através de oficinas de Coordenação de Mulheres da Fundação Nacional do Índio. A autora aponta que, em geral, e mais especialmente em áreas onde a vida considerada 'tradicional' é supostamente mais preservada e identifica-se que há mais consciência do valor da autonomia do estado. Como no caso dos habitantes do Parque do Xingu (MT), em que os caciques e os homens estão presentes e apresentam o argumento de que não há nada que o Estado deva conversar com suas mulheres. De acordo com Segato, tal argumento se constrói a partir da afirmação de que seu mundo "sempre foi assim", isto é, que o controle que exercem sobre as mulheres é um controle que sempre houve.

Segato, no entanto, aponta que a resposta a tal afirmação é complexa. Isto porque, para ela, se é verdade que um tipo de hierarquia sexual sempre existiu no mundo da aldeia, havia também uma característica própria dessa relação que foi 
ameaçada pela interferência e colonização pelo espaço público republicano, que "expulsa a diferença para uma posição marginal e problemática - o problema do "outro" ou a expulsão do outro para a qualidade de "problema"” (p. 79, tradução nossa $^{31}$ ). Segundo a autora, essa inflexão introduzida, em primeiro lugar, pela administração colonial da base ultramarina e, depois, pela gestão colonial/estatal, "tem como primeiro de seus sintomas a cooptação dos homens como classe ancestralmente dedicada às tarefas e funções do espaço público com suas características pré-intrusivas" (idem $\left.{ }^{32}\right)$.

Nesse processo, a posição masculina é realocada e ressignificada, mas esta mudança não altera a nomenclatura anterior. Segundo Segato, a partir disto, se institui uma narrativa dos homens da aldeia que sustenta que eles são o que sempre foram, mas que esconde que já operam em uma nova lógica.

Para Segato, a escolha dos homens da aldeia como interlocutores principais foi funcional aos interesses da colonização e a eficácia de seu controle. Ela significou retirar radicalmente das mulheres da aldeia qualquer poder político que estas tinham até então. Com o objetivo de obter aliados e facilitar o empreendimento colonial, os colonizadores negociaram com certas estruturas masculinas (ou as inventaram) e promoveram uma maior sujeição das mulheres (GAUTIER, 2005 apud SEGATO, 2014).

As mulheres e a própria aldeia se tornam agora parte de uma externalidade objetiva para o olhar masculino, contagiado, por contato e imitação, do mal da distância e exterioridade próprias do exercício do poder no mundo da colonialidade. A posição dos homens se tornou agora simultaneamente interior e exterior, com a exterioridade e capacidade objetificadora do olhar colonial, simultaneamente administradora e pornográfica. [...] a sexualidade se transforma, introduzindo-se uma moralidade antes desconhecida, que reduz a objeto o corpo das mulheres e ao mesmo tempo introduz a noção de pecado, crimes nefastos e todos os seus correlatos. Devemos atribuir à exterioridade colonial/moderna exterioridade da racionalidade científica, exterioridade administradora, exterioridade expurgadora do outro e da diferença já apontada por Aníbal Quijano (1992) e por Walter Mignolo ([2000] 2003: 290-291 e 424), em seus textos -

\footnotetext{
31 "expele la diferencia a una posición marginal, problemática —el problema del 'otro', o la expulsión del otro a la calidad de "problema"".

32 "tienen, como el primero de sus síntomas, la cooptación de los hombres como la clase ancestralmente dedicada a las faenas y papeles del espacio público con sus características preintrusión".
} 
esse caráter pornográfico do olhar colonizador (SEGATO, 2014, p. 80, tradução nossa ${ }^{33}$ ).

Segato (2014) aponta que ao mesmo tempo em que a posição masculina do homem na aldeia é inflada, ele sofre uma emasculação frente ao domínio soberano do homem branco colonizador. Neste violento processo, o homem da aldeia se posiciona no lugar de reprodução e exibição da capacidade supostamente inerente "de controle do sujeito masculino no único mundo agora possível, para restaurar a virilidade danificada na frente externa" (p. 81).

Para Segato, fazem parte também do panorama de captura do gênero préinvasão colonial pelo sistema de gênero moderno/colonial, o sequestro, por parte da crescente e expansiva esfera pública republicana, de todas as deliberações sobre o bem comum. A consequente privatização do espaço doméstico, marginaliza e expropria dele tudo o que era um fazer político. Neste processo, são dilacerados os vínculos exclusivos entre as mulheres, que orientaram a reciprocidade e a colaboração conjunta tanto ritual quanto nas tarefas produtivas e reprodutivas. Produz-se com isso um colapso do valor e munição política das mulheres, que ficam totalmente excluídas da participação nas decisões que afetam a coletividade.

A ruptura dos laços entre as mulheres, a partir do confinamento do espaço doméstico, significou uma enorme precarização das alianças políticas por eles permitidas e teve consequências terríveis para a segurança das mulheres. Elas se tornaram mais vulneráveis à violência masculina, que nesse mesmo momento era impulsionada pela pressão do mundo exterior sobre os próprios homens da aldeia (SEGATO, 2014).

\footnotetext{
33،"Las mujeres y la misma aldea se vuelven ahora parte de una externalidad objetiva para la mirada masculina, contagiada, por contacto y mímesis, del mal de la distancia y exterioridad propias del ejercicio del poder en el mundo de la colonialidad. La posición de los hombres se tornó ahora simultáneamente interior y exterior, con la exterioridad y capacidad objetificadora de la mirada colonial, simultáneamente administradora y pornográfica. De forma muy sintética, que no tengo posibilidad de extender aquí, anticipo que la sexualidad se transforma, introduciéndose una moralidad antes desconocida, que reduce a objeto el cuerpo de las mujeres y al mismo tiempo inocula la noción de pecado, crímenes nefandos y todos sus correlatos. Debemos atribuir a la exterioridad colonial/moderna —exterioridad de la racionalidad científica, exterioridad administradora, exterioridad expurgadora del otro y de la diferencia ya apuntada por Aníbal Quijano (1992) y por Walter Mignolo ([2000] 2003: 290-291 y 424), en sus textos- ese carácter pornográfico de la mirada colonizadora".
} 
Segato afirma que, embora no espaço público das aldeias de um grande número de povos fosse reservado aos homens deliberar, restringindo de forma precisa a participação e a fala feminina, a consulta às mulheres no espaço doméstico antes da tomada final das decisões era prevista. "Isto é comum e ocorre em um mundo claramente compartimentado onde, embora haja um espaço público e um espaço doméstico, a política, como um conjunto de deliberações que levam a decisões que afetam a vida coletiva, atravessa os dois espaços" (p. 82). Regulado desta maneira, o gênero constitui uma dualidade hierárquica em que, apesar de sua desigualdade, os termos que o compõem têm plenitude ontológica e política.

No mundo da modernidade institui-se um binarismo que transforma essa relação de complementaridade em uma relação suplementar. Isto é, um desses termos se torna "universal", de representatividade geral enquanto o outro se torna o resto. Na estrutura binária, "o que era hierarquia torna-se um abismo" (SEGATO, 2014, p. 82, tradução nossa ${ }^{34}$ ).

Maria Galindo (2015) também compartilha do pensamento de que já haviam estruturas patriarcais na organização das sociedades nativas de Abya Yala. Ela considera que, a partir de uma perspectiva masculina, na história da relação colonial ficam ocultas as continuidades entre as instituições patriarcais précoloniais e as coloniais e sobre o papel que desempenharam no processo de consolidação do colonialismo.

No entanto, Galindo também reconhece que seja qual fosse o caráter précolonial da relação homem-mulher, esta foi completamente atravessada pelo colonialismo, fazendo com que a mulher colonizada adquirisse um valor distinto, assim como o homem. Segundo ela, o colonialismo produz uma combinação particular da hierarquia homem-mulher com a hierarquia étnico-racial, resultando na existência de uma complexa tipologia racializada de homens e de mulheres. Desta maneira, considera que a fusão entre colonialismo e patriarcado é uma matriz estruturadora de todas as relações sociais modernas.

O colonialismo introduz um tipo de contrato sexual para a união homem-mulher branca e outro tipo de contrato sexual paralelo para o relacionamento índio-índia; dá ao homem branco um duplo código de acesso simultâneo a mulheres brancas e mulheres indígenas, mas sob status diferente; recolhe as instituições pré-coloniais

\footnotetext{
34“lo que era jerarquía se transforma en abismo".
} 
e aproveita o caráter de objeto de troca política das mulheres indígenas para consolidar o colonialismo através da aliança patriarcal conquistador-conquistado (GALINDO, 2015, p. 38, tradução nossa) ${ }^{35^{5}}$.

Não há a pretensão de estabelecer uma verdade acerca da existência ou não de sistemas de poder baseados na hierarquia sexual nas sociedades précoloniais. As sociedades nativas das regiões colonizadas eram muitas e muito diversas em termos de organização e costumes. Seria até mesmo contraditório com o que vem sendo pautado pelos estudos decoloniais a busca por uma resposta única, uma verdade que respondesse universalmente às dinâmicas organizativas de todos esses grupos. Ao contrário, reconhecemos a importância de todos esses estudos, em especial porque eles vão ao encontro da perspectiva de que o patriarcado não é uma produção natural e universal, mas histórica e, portanto, capaz de ser abolido pela alteração de condições históricas.

No entanto, o que nos parece ponto comum entre as teóricas feministas com quem dialogamos é que, em diferentes termos, todas elas consideram que o sistema de gênero moderno/colonial impõe mudanças radicais a vida das mulheres. São categóricas ao afirmar que a colonização teve impacto devastador especialmente para as mulheres dos grupos colonizados. Elas também compartilham do interesse sobre o modo como se instaurou uma colaboração entre homens colonizados e homens colonizadores que enfraqueceu o poder das mulheres, ainda que estas tenham sempre resistido fortemente. Um interesse que surge da necessidade de compreender a indiferença dos homens de seus próprios grupos raciais e econômicos às lutas das mulheres contra a condição de subordinação radical, que alia raça, gênero e classe, na modernidade/colonialidade.

\subsection{Dispositivos de subordinação das mulheres na modernidade/colonialidade}

\footnotetext{
${ }^{35} \mathrm{El}$ colonialismo introduce un tipo de contrato sexual para la unión hombre-mujer blancos y otro tipo de contrato sexual paralelo para larelaciónindia-indio; otorga al hombre blancoun doble código de accesosimultáneo a lasmujeresblancas y a lasindias pero bajo estatus diferentes; recogelasinstitucionesprecoloniales y aprovechael carácter de objeto de intercambio político de lamujerindia para consolidar el colonialismo a través de laalianza patriarcal conquistadorconquistado".
} 
É a partir da segunda metade do século XX que a categoria gênero ganha uma releitura feminista e passa a ser central nas ações políticas e nas teorias produzidas pelo feminismo. Mas é especialmente a partir da década de 1970, momento em que o feminismo enquanto movimento social se fortalece, que as feministas se apropriam do conceito de gênero para construir suas análises sociais. Dentre as diversas vertentes feministas existentes nesta época, um ponto em comum era o pensamento de que as posições designadas às mulheres como naturais (mães, esposas, dependentes) não eram destino biológico, e sim de construções sociais e culturais (BEAUVOIR, 2009; SCOTT, 1989; CURIEL, 2009).

Em meados do século XX, de diferentes ângulos, pensadoras como Mary Wollstonecraft, Margaret Mead e Simone de Beauvoir produziram teoricamente questionamentos sobre naturalização das diferenças sexuais, apontando horizontes para uma dessencialização dos papéis sociais designados às mulheres (MAYORGA et al, 2013). Nos anos 70, Kate Millet, escreve um texto central para o feminismo, intitulado "Sexual Politics" (1970), em que afirma, dentre outras coisas, que as diferenças entre homens e mulheres eram sociais. Em 1972, a categoria gênero é pela primeira vez utilizada, pela socióloga britânica Ann Oakley, para afirmar que o sexo se referia a divisão biológica entre homem e mulher enquanto o gênero tratava da desigual divisão social entre feminilidade e masculinidade.

Em 1975, a antropóloga norte-americana Gayle Rubin, em seu texto "O tráfico de mulheres: notas sobre a Economia Política do Sexo", retoma o gênero como uma categoria política para o feminismo, analisando a subordinação das mulheres baseada nas relações sociais que organizam e produzem a sexualidade e o gênero. Nesta perspectiva, cria a noção de "sistema sexo-gênero", definindo-a como uma "série de arranjos pelos quais uma sociedade transforma a sexualidade biológica em produtos da atividade humana, e nos quais essas necessidades sexuais transformadas são satisfeitas" (RUBIN, 1975, p. 159 apud RUBIN, 2003, p. 48). Assim, a autora apontava o sexo como moldado pela intervenção social e, portanto, a origem da opressão das mulheres se encontrava no social e não no biológico. 
De acordo com Curiel (2009), toda essa produção teórica contribuiu para os estudos de gênero e a perspectiva de gênero, que acabaram substituindo significativamente os estudos da mulher e os estudos feministas. Segundo ela, outra razão para o surgimento dos estudos de gênero e perspectivas de gênero tem a ver com a necessidade de legitimação das lutas feministas nos espaços acadêmicos e nos movimentos sociais, muito em função da busca por financiamento em agências de cooperação. Isto porque, em comparação às supostas ameaças que os estudos denominados feministas implicavam, em especial para os acadêmicos homens, o gênero surge como um termo mais palatável. A esse respeito, Mayorga et al (2013), apontam:

A substituição do termo "mulher" (estudos da mulher ou de mulheres) pelo de "gênero" (estudos de gênero) possibilitou a introdução de estudos sobre a mulher em espaços até então tidos como impenetráveis, pois gênero representava certo status e sofisticação às pesquisas, além de ter uma conotação mais objetiva e neutra. Desse modo, a utilização do conceito "gênero" foi importante para que o tema "mulher" fosse introduzido com maior facilidade pelos discursos oficiais e pudesse denunciar os pressupostos androcêntricos e sexistas das instituições e nas relações sociais, [...] No entanto, ao longo do tempo, "deixou-se de lado a crítica feminista, a opressão e a subordinação da mulher, diluiu-se e neutralizou-se nos discursos e práticas de tais instituições". Na intenção de não nomear algumas noções, tais como homem e mulher, e para evitar posições essencialistas, o que acabou resultando em um "feminismo sem mulheres". A partir desse momento, podia-se estudar a opressão da mulher e as relações desiguais sem assumir um projeto político feminista (pp. 468-469).

Em 1986, no texto "Gênero: uma categoria útil para a análise histórica", amplamente difundido, o gênero é apresentado pela historiadora norte-americana Joan Scott como "um elemento constitutivo de relações sociais baseado nas diferenças percebidas entre os sexos, e o gênero é uma forma primeira de significar as relações de poder" (SCOTT, 1995, p. 86). Baseando-se na perspectiva de que as transformações na organização das relações sociais sempre correspondem à mudança nas representações de poder, ela explica que o gênero implica elementos como: os símbolos culturais que evocam representações múltiplas (muitas vezes contraditórias); conceitos normativos que evidenciam interpretações do sentido dos símbolos (expressos em doutrinas religiosas, educativas, científicas, legais e políticas na posição binária de masculino/feminino); o papel político nas instituições e organizações sociais (para além do sistema de parentesco, do universo doméstico e da família); e a identidade subjetiva. 
Mas essa perspectiva de gênero tem sido, dentro do próprio feminismo, colocada em questão. Um dos pontos criticados diz respeito ao fato do gênero ser analisado como a construção social do sexo, sendo o sexo, portanto, assumido como parte natural preexistente (WITTIG, 1992; SWAIN, 2017). O outro ponto, trazido especialmente por teóricas pós-coloniais, feministas negras e feministas lésbicas, denuncia as hierarquias existentes na própria classe de mulheres e a invisibilização disto nos estudos de gênero produzidos pelas feministas do Norte Global. Essas críticas argumentam que as opressões e violências vividas por mulheres negras ou não brancas e pobres na modernidade/colonialidade têm características específicas que o gênero, ao ser analisado isoladamente e abarcar uma abstração universalizante da mulher, silencia (LUGONES, 2008; CURIEL, 2009).

Em relação ao primeiro ponto, de acordo com a historiadora feminista brasileira Tania Navarro Swain (2017), nos vemos diante da seguinte questão:

se o binômio instigador de tantas análises - sexo/gênero - aparece em um de seus termos - o sexo - como reproduzindo a naturalização criticada, como pensar o mundo além do binário sexual e sexuado, uma vez que estamos nele inseridos, enquanto gênero demarcado pelo biológico? (SWAIN, 2017, s/p).

Em primeiro lugar, Swain considera um erro compreender o sistema sexo/gênero como estrutural e estruturante de todas as sociedades e temporalidades, pois esta perspectiva naturaliza não apenas os papéis sociais fundamentados no biológico, mas atribui também à sexualidade uma fundamental “importância 'natural' na construção das relações sociais, como algo já-dado, prédiscursivo, independente das relações sociais e das práticas singulares à cada sociedade" (2017). Segundo a historiadora, isto não pode ser assegurado, pois não é possível dizer que em todas as sociedades e tempos havia uma regulação social baseada no sexo, na procriação ou na sexualidade.

Em segundo lugar, Swain aponta que há uma domesticação epistemológica da categoria gênero na medida em que ela opera na "casa do senhor", isto é, na economia de uma ordem binária do humano, instituída pela ordem patriarcal em que estamos inseridas/os. Segundo ela, o aspecto relacional do gênero na construção do humano sexuado escamoteia a economia hierárquica e assimétrica 
da construção dos gêneros. Ele esconde "a face do poder na instituição dos sexos como fundamento dos gêneros" (2017).

Swain argumenta que a ideia da existência de uma diferença "natural" entre os sexos oculta que os valores dados a essas diferenças são valores sociais, isto é, engendrados dentro de sistemas sociais, sempre localizáveis histórica e socialmente. Ela ressalta que há um processo de diferenciação inerente a toda "diferença" que não pode ser desconsiderado. Não existe o diferente sem um referente. Sempre se é diferente em relação a algo ou alguém. Assim,

Não se é homem ou mulher fora de práticas sociais valorativas que definem lugares de fala, de autoridade, de importância. Desta forma, o sexo é uma criação do gênero, ou seja, das práticas sociais que criam "referente" e "diferente" e instalam categorias de forma binária e hierárquica (SWAIN, 2017, s/p).

Para Swain, a diferença entre as sexualidades femininas e masculinas existe porque os sujeitos "nascem de construções representacionais e imagéticas em torno da construção política dos gêneros e da vontade de poder do patriarcado" (2017). Por isso, a autora considera um equivoco compreender o gênero como um instrumento descritivo, afirmando que ele deve ser visto como uma categoria de análise.

De acordo com Swain, em um sistema social patriarcal, através do gênero se produz uma diferença política cuja justificativa está ancorada nos corpos, dotando a genitália das marcas do superior e do inferior. Neste sentido, gênero seria um dispositivo de poder forjado no interior de sistemas sociais patriarcais para produz a "diferença sexual” e, portanto, para subalternizar as mulheres.

A suposta "diferença" preexistente entre os sexos é afirmada com o objetivo de naturalizar e justificar o controle e a dominação do sexo masculino sobre o sexo feminino. No entanto, na realidade, são os discursos sociais patriarcais que produzem o sexo - corpos biológicos - e a sexualidade - práticas sexuais - em uma lógica binária e hierárquica.

A diferença, de fato, é política, o corpo é marcado pelo sexo e o corpo das mulheres se torna assim espaço de domínio masculino. O "natural" aqui, do corpo biológico, dotado de certas particularidades, atrela-se ao político, na medida em que define um comportamento "normal" a partir de valores criados pelo social. A genitália, torna-se, deste modo, causa de uma sexualidade paradigmática, uma heterossexualidade reprodutiva, cujo ônus recai, principalmente sobre as mulheres (SWAIN, 2017, s/p). 
Monique Wittig, feminista materialista francesa, em "A categoria dos sexos", originalmente publicado em 1982, analisou como a "diferença sexual" que define mulheres e homens como dois sexos é imaginária e oculta o que acontece no plano econômico, político e ideológico. Para ela, a divisão entre "diferentes" premissas sexuais, tem efeitos materiais e ao mesmo tempo é abstrata, sendo conceituada por quem detém poder e hegemonia: os homens.

Wittig (1992) analisa assim a categoria do sexo como uma categoria de dominação social das mulheres por homens. De acordo com ela, trata-se de:

[...] uma categoria totalitária, que para confirmar-se tem suas inquisições, suas cortes, seus tribunais, seu corpo de leis, seus terrores, suas torturas, suas mutilações, suas execuções, sua polícia. Ela engendra a mente tanto quanto ao corpo, uma vez que controla toda produção mental. Ela agarra nossas mentes de tal forma que não podemos pensar fora dela. É por isso que devemos destruí-la e começar a pensar para além dela, se quisermos começar realmente a pensar, do mesmo jeito que temos que destruir os sexos como realidade sociológica se quisermos começar a existir (p. 8, tradução nossa) ${ }^{36}$.

Wittig defende que a categoria do sexo é o produto de uma sociedade heterossexual, que impõe às mulheres a obrigação da reprodução da 'espécie', ou seja, da reprodução da sociedade heterossexual. Segundo ela, é através desse sistema de exploração, que impõe uma reprodução compulsória pelas mulheres, que a heterossexualidade se baseia economicamente - "é essencialmente, através da reprodução, esse trabalho, essa produção feita por mulheres, que todo o trabalho feminino é apropriado pelos homens" (p. 6, tradução nossa) ${ }^{37}$.

Essa apropriação do trabalho "natural" das mulheres, a que Wittig se refere, inclui a reprodução, a criação de crianças e as tarefas domésticas. Para a autora, trata-se de uma apropriação executada da mesma forma que a apropriação do trabalho da classe trabalhadora pela classe dominante. No entanto, no caso das mulheres a produção (que é a reprodução) é tida como "natural" enquanto a outra é vista como social, uma perspectiva que é "tão somente a justificação teorética ideológica da opressão, um argumento para fazer mulheres acreditarem que antes

\footnotetext{
36“"For thecategoryof sex is a totalitarianone, whichto prove truehas its inquisitions, its courts, its tribunals, its bodyoflaws, its terrors, its tortures, its mutilations, its executions, its police. It shapesthemind as well as thebodysince it controlsall mental production. It gripsourminds in such a waythatwecannotthinkoutside of it. Thisiswhywe must destroy it and start thinkingbeyond it ifwewantto start thinkingatall, as we must destroythesexes as a sociological reality ifwewantto start toexist".
37 "Reproductionisessentiallythatwork,
thatproductionbywomen, throughwhichtheappropriationbymenofalltheworkofwomenproceeds".
} 
da sociedade e em todas as sociedades elas estão sujeitas a essa obrigação de reproduzir-se" (idem) $)^{38}$.

Tereza de Lauretis (1994) chamou de "tecnologias do gênero" o conjunto de dispositivos de poder que produzem o sujeito feminino. Tais tecnologias, criadas pelo patriarcado, atuam transformando o que Swain (2017) chamou de "corpos-sexuados-em-mulher".

De acordo com Swain (2017), nas tecnologias do gênero o dispositivo amoroso, por exemplo, é o que caracteriza as pessoas do sexo "feminino" como seres pautados principal e naturalmente pelo sentimento, pelo cuidado e doação ao outro. É ele quem constrói a ideia de que o "amor" (tido como sinônimo de subserviência) para as mulheres é uma necessidade, uma razão de viver e ser, um fundamento identitário.

O dispositivo amoroso investe e constrói corpos-em-mulher, prontos a se sacrificar, a viver no esquecimento de si pelo amor de outrem. [...] Essa disposição amorosa, por outro lado, as conduz diretamente para uma heterossexualidade incontornável, coercitiva, sem equívocos, já que a procriação é sua recompensa. Mesmo se o prazer é raro ou ausente, é uma sexualidade sem questões, sem desvios, é assim, ponto (SWAIN, 2017, s/p).

Para Swain (2017), ancorada nesses corpos sexuados, a identidade das mulheres é essencializada nas tarefas sociais da procriação e da maternidade (que carrega um sentido cultural específico para a reprodução). Tanto uma quanto a outra são postas como objetivo principal. Nesta perspectiva, a maternidade faz parte do conjunto de características e desempenhos de "natureza" feminina, que se completa pela companhia de um homem. Esta tarefa naturalizada, "cria um campo de silêncio em torno das ações políticas das mulheres, em seu sentido mais amplo, que abrange inclusive o domínio socioeconômico" (SWAIN, 2017). Para a autora, a própria ideia de uma separação rígida e persistente entre o público e privado se funda nesta naturalização de papéis.

A categoria "heterossexualidade compulsória" foi formulada por Rich (2010), para desenvolver o pensamento de que a heterossexualidade é uma instituição política que atua em todas as relações sociais e não apenas nas sexuais.

\footnotetext{
38،"Thisargumentisonlythetheoretical, ideologicaljustification of oppression, anargument to makewomenbelievethatbeforesociety and in allsocietiesthey are subject to thisobligation to reproduce".
} 
Para ela, a instituição de um regime heterossexual obrigatório retira o poder das mulheres em vários âmbitos da vida - nas relações sociais, no sistema produtivo, no trabalho e sua remuneração, no governo, entre outros.

Rich considera que existem muitas formas do poder masculino se manifestar, sendo algumas mais fáceis de serem reconhecidas e outras mais difíceis. No entanto, todas elas "vem adicionar-se ao feixe de forças pelo qual as mulheres têm sido convencidas de que o casamento e a orientação sexual voltada aos homens são vistos como inevitáveis componentes de suas vidas - mesmo se opressivos e não satisfatórios” (2010, p. 26).

De acordo com Rich, esse convencimento se dá através do que denominou “ideologia heterossexual do amor". Tal ideologia se irradia nas mulheres desde a infância através, por exemplo, dos contos de fadas, dos programas de televisão, dos filmes, da propaganda, das canções, das cerimônias de casamento. Segundo ela, esses meios - que podemos pensar como tecnologias do gênero - reconstroem incessantemente a ideologia heterossexual do amor.

De acordo com Swain, o compulsório "natural" da heterossexualidade "abre espaço para todas as violências transformando seres humanos em corpos sexuados: os disponíveis - o feminino - para outrem - o masculino" (SWAIN, 2017). Se as mulheres não cumprem o "destino biológico" de atender as necessidades masculinas, não são consideradas "verdadeiras mulheres".

O pensamento de Rich (2010) também nos possibilita compreender a atuação das tecnologias de gênero na construção/sujeição dos corpos-sexuadosem-mulher através da multibilionária indústria pornográfica, que dissemina imagens objetificadas, humilhantes e sádicas das mulheres. Como aponta a autora, mesmo a propaganda e a pornografia ditas "leves" apresentam as mulheres como objetos de apetite sexual, como uma mercadoria sexual para consumo dos homens. Deste modo, a pornografia não cria meramente uma atmosfera na qual sexo e violência seriam intercambiáveis, mas "amplia o conjunto de comportamento considerado aceitável para os homens em seus intercursos heterossexuais" (p. 27) e subtrai das mulheres sua autonomia, sua dignidade e seu potencial sexual, inclusive de amar outras mulheres. 
De acordo com Swain, a categoria heterossexualidade compulsória deflagra "o poder embutido na identificação estreita entre sobrevivência da espécie, meio de fecundação, relações emocionais e eróticas" (2017). Neste sentido, considera que a ideia, proposta por Crys Ingraham, de "heterogênero", em lugar de "gênero" possibilita uma desmistificação da construção social de corpos sexuados no sistema político específico que é o patriarcado (fundado pela heterossexualidade compulsória) e da invenção da "diferença sexual" que constrói as mulheres "como especificidade do humano, arquitetada em corpo e ventre, cujo objetivo é o prazer e a reprodução dos homens" (idem).

Criar e justificar hierarquias entre grupos humanos baseadas nas “diferenças naturais" não foi uma estratégia criada apenas pelo poder patriarcal para subalternizar mulheres. Como vimos anteriormente, no processo de colonização, a cor da pele e outras características físicas foram transformadas em “diferença racial” para justificar a escravização do povo negro e indígena.

A raça forjou-se como um dispositivo de poder político colonial usado para estabelecer diferenciações assimétricas e hierárquicas entre grupos humanos. Foi, como disse Fanon (1980), uma invenção branca para justificar e legitimar a subalternização e escravização de povos africanos durante séculos. Ou, como coloca Quijano (1997), "negro" e "índio" foram categorias inventadas pelos colonizadores europeus, que ao se autodeterminarem como referência de humanidade, produziram o "outro" a ser subalternizado sob a justificativa dessa "diferença" natural.

Como aponta Fanon (1980), foi no biológico que a priori o racismo pretendeu encontrar sua base material, comparando aspectos microscópicos da epiderme, crânios, dimensões vertebrais, etc. Com o passar do tempo, uma argumentação mais elaborada vai sendo construída. Primeiro a afirmação da existência de grupos humanos sem cultura, depois, da existência de culturas hierarquizadas, chegando a noção de relatividade cultural (FANON, 1980).

Às multiplicidades morfo-biológicas foram atribuídos valores sociais de diferenciação e qualificação em termos de "raças humanas". Neste processo o conceito "raça" foi transportado da Zoologia e Botânica, onde foi originalmente 
usado para classificar espécies animais e vegetais (MUNANGA, 2003) e isto, em certa medida, revela o caráter desumanizador que constitui esse processo.

Foi, portanto, o racismo que criou a "diferença racial", construindo a ideia de diferentes raças humanas, e não o contrário. Se invertermos essa análise, acabamos por admitir a existência de "diferentes" raças humanas como um dado natural, preexistente, o que, como hoje as próprias ciências biológicas confirmam, não é verdade (MUNANGA, 2003).

Nossas diversidades fenotípicas, que podem ser percebidas, são resultado de lentos processos históricos de adaptações climáticas (JESUS, 2018; MOORE, 2007). Como aponta Moore (2007), raça não é um conceito que possa ser definido segundo critérios biológicos, mas como uma construção sociopolítica. Já o racismo é "um fenômeno que antecede sua própria definição" (MOORE, 2007, p. 38). A ideia de raças humanas diferentes foi criada pelo racismo para desumanizar e justificar a exploração de determinados grupos.

Nessa perspectiva, em termos de sistemas sociais patriarcais e racistas, poderíamos pensar tanto a categoria "gênero" quanto a categoria "raça" fundamentalmente como dispositivos de poder forjados no interior desses sistemas para justificar a subalternização de determinados grupos. Tais dispositivos, no entanto, não se fundam em uma "diferença natural" preexistente, mas produzem socialmente essas diferenças, instalando um sistema binário de poder em que ser do "sexo feminino" (para o patriarcado) ou ser da "raça negra" ou de uma raça que não a "raça branca" (para o racismo) significa desempenhar certas funções sociais subalternas e, portanto, ter um lugar de ação e importância restrito e passível de exploração e violência extrema - eles produzem a/o "Outra/o".

Mas na modernidade/colonialidade estes sistemas não funcionam isoladamente. Como vimos, o sistema capitalista moderno/colonial é estruturado pelo racismo, pelo sexismo e pelo classismo imbricadamente. Partindo deste olhar é que se formulam as críticas das feministas negras, pós-coloniais e lésbicas, especialmente do Sul Global, à categoria gênero tal como admitida pelo feminismo do norte. 
Curiel (2015) pergunta: "São mulheres as mulheres negras e indígenas de hoje, que ainda seguem sendo produzidas pela colonialidade? Em que sentido são e em quais não?” (CURIEL, 2015, p. 18, tradução nossa ${ }^{39}$ ).

A partir da década de 70, o feminismo materialista francês - surgido no calor do movimento social de libertação das mulheres e em estreita ligação com ele - desenvolve um conjunto teórico particularmente denso e convergente que permite pela primeira vez explicar a opressão da mulher como classe social. Reunido em torno da revista Questions Féministes, um pequeno grupo de feministas da vertente radical do movimento francês "analisava a existência sexual de mulheres e homens - como um fenômeno de classe" (CURIEL E FALQUET, 2005, p. 4) ${ }^{40}$.

A partir dessa perspectiva, as feministas materialistas elaboraram uma teoria absolutamente anti-naturalista e radical da situação das mulheres. Como apontam as Curiel e Falquet (2005), com análises de caráter profundamente revolucionário, essas feministas confrontaram diretamente o poder e os privilégios masculinos, assim como de parte das mulheres, já que vão muito além de pedir uma simples revalorização do "feminino", colocando em questão a suposta "complementariedade" dos sexos e sua existência "natural".

É a partir dessa perspectiva que Wittig (1992) constrói a análise de que as categorias "homem" e "mulher" não são categorias naturais e definitivas, mas políticas e econômicas que, portanto, não existem fora das construções sociais que a definem. A partir disso, aponta a necessidade de desassociar por completo "mulheres", isto é, a classe dentro da qual lutamos, produto de uma relação social, e "mulher", o mito, a formação imaginária construída dentro e fora de nós. Para ela, é fundamental compreender que "mulher não é cada uma de nós, mas a formação política e ideológica que nega "mulheres" (o produto de uma relação de exploração)" (pp. 15-16, tradução nossa ${ }^{41}$ ).

\footnotetext{
39، ¿Son mujeres las mujeres negras e indígenas de hoy, que aún siguen siendo producidas por la colonialidad? ¿En qué sentido lo son y en cuáles no?”

40 "que permitía por primera vez dar cuenta de la opresión de las mujeres en cuanto clase social, es decir, que analizaba el sexo - la existencia de mujeres y varones—-, como un fenómeno de clase".

41 "Woman" isnoteachone of us, butthepolitical and ideologicalformationwhichnegates "women" (theproduct of a relation of exploitation)".
} 
Nessa perspectiva, Wittig propõe que a luta feminista deve tentar destruir os homens como classe política, pois só o desaparecimento desta classe de "homens" é possível o desaparecimento da classe de "mulheres". Para ela é uma necessidade absoluta para a nossa sobrevivência fazer desaparecer a classe das mulheres da qual os homens se apropriam, o que só pode ser alcançado pela destruição do sistema social baseado na opressão das mulheres pelos homens, que produz a doutrina da diferença entre os sexos para justificar essa opressão, isto é, a heterossexualidade.

Mas a pergunta feita por Curiel (2015) sobre até que ponto mulheres negras e indígenas são mulheres na sociedade capitalista moderna/colonial levanta questões sobre a categoria "mulher" tal como compreendida pelas feministas brancas ocidentais. Considerando as hierarquias e diferenciações existentes no interior da classe das mulheres, a autora problematiza os limites da categoria gênero, tal como vem sendo discutida pelo feminismo ocidental embranquecido, na análise das opressões vividas pelas mulheres pertencentes as classes raciais e econômicas subalternizadas.

Andrea Gill e Thula Pires (2019) analisam a tradição do pensamento ocidentalizado em interpretar as relações de dominação a partir da perspectiva da dialética senhor/escravo. As autoras apontam que constituídas desta maneira, as práticas críticas (inclusive feministas) "se concentram em um encontro dialético binário, ou mais precisamente, entre forças opostas e mutuamente exclusivas que mediam seu (auto)reconhecimento e posicionamento relativo de maneiras ostensivamente interdependentes" (p. 278, tradução nossa) ${ }^{42}$. Uma das consequências da utilização desse método de análise, segundo as autoras, é que, ao abstrair os movimentos e dinâmicas da história, acaba por conceber liberdade, autonomia e subjetividade de um modo que reflete e reproduz termos e condições necessárias para criar pactos políticos que, ao contrário de romperem com os sistemas modernos de governamento, o sustentam.

Em contraposição a essa abordagem binária, Gill e Pires dialogam com o pensamento desenvolvido por Fanon (2008). As autoras consideram que a

\footnotetext{
42 "Practices of critique so informedfocus in on a binary, or more preciselyput, dialecticencounterbetweenopposing and mutually exclusive forcesthatmediatestheir (self)recognition and relativepositioning in ostensiblyinterdependentways".
} 
concepção dialética das relações de poder desenvolvida por esse autor "abre caminho para um relato da lógica e operação da colonialidade, de múltiplas hierarquias imbricadas estabelecidas dentro de uma (des)classificação racializada da humanidade" (p. 282, tradução nossa ${ }^{43}$ ).

$\mathrm{Na}$ importante obra "Peles negras, Máscaras Brancas", Fanon (2008) analisa a vida psíquica do poder, formulando uma ampla e profunda crítica do colonialismo. Nesta análise, ele considera os efeitos da dominação colonial não apenas nos colonizados, mas também nos colonizadores. Como apontam Pires e Gill (2019), trata-se de uma análise situada na qual não se parte de uma reciprocidade ou de um reconhecimento absoluto, mas que compreende a dinâmica marcada pelo deslocamento constante do que ele denomina 'posição não refletida' do sujeito negro colonizado, isto é, para aquele que "a ideia de subjetividade, ontologia, epistemologia e todo o aparato das ciências e humanidades modernas/coloniais, com base em um mito branco de individualidade, é inaplicável” (p. 282, tradução nossa ${ }^{44}$ ). E acrescentam:

Uma vez que entendemos como as estruturas da colonialidade e sua lógica de governo supremacista branca estabelecem termos de (des)qualificação possível que posicionam sujeitos não-brancos dentro de uma zona de não-ser, a questão de entrar na dialética pode ser entendida como uma questão de luta política, o objetivo de um movimento antirracista, nos termos de Fanon, e não uma descrição das posições reais ocupadas (PIRES e GILL, 2019, p, 282, tradução nossa $)^{45}$.

Como defende Curiel (2016), a discussão sobre a opressão de gênero na modernidade não pode se desenvolver sem levar em conta a noção de humanidade imposta pela colonialidade. No colonialismo, as/os indígenas e as/os negras/os não foram considerados humanas/os. Essa desumanização altera o modo como a construção política dos sexos instituída pelo dispositivo de poder patriarcal "gênero" opera nas relações estabelecidas entres a classe de mulheres e a classe de homens na modernidade/colonialidade.

\footnotetext{
43 "opens wayforanaccount of thelogic and operation of coloniality, of multipleimbricatedhierarchies set within a racialised (de)classification of humanity".

44 "thecolonisedblacksubject, forwhomthe idea of subjectivity, ontology, epistemology and thewholeapparatus of modern/colonial sciences and humanities, basedon a whitemyth of individuality, isinapplicable".

45 "Once of coloniality and itsgoverningwhitesupremacistlogicestablishtheterms of possible (dis)qualificationthat position non-whitesubjectswithin a zone of non-being, thequestion of enteringintothedialectic can be understood as a matter of politicalstruggle, theaim of an anti-racistmovement, in Fanon'sterms, and not a description of actual positions occupied".
} 
O conceito de colonialidade do ser, cunhado pelo porto-riquenho Nelson Maldonado-Torres (2007) trata justamente dessa negação de humanidade às populações colonizadas (indígenas e negras). Como vimos, a desumanização dessas populações justificou sua escravização, a expropriação de suas terras, a desqualificação de seus saberes (colonialidade do saber) e o genocídio.

Lugones (2008) aponta que as fêmeas colonizadas não eram consideradas humanas, mas eram marcadas sexualmente como fêmeas, ainda que sem ser a elas atribuídas características da feminilidade. A autora afirma que, mesmo quando foram "engenerizadas", recebendo o status inferior que acompanha o gênero mulher, isto se deu imbricadamente ao status de não humanidade atribuído pelo racismo aos grupos raciais aos quais pertenciam, colocando essas mulheres em uma posição radicalmente subalternizada.

Para Lugones, há um lado visível/claro e um lado oculto/obscuro do sistema de gênero moderno/colonial. $O$ lado visível/claro constrói, hegemonicamente, o gênero e as relações de gênero, organizando, de fato e direito, somente a vida de homens e mulheres brancos burgueses e constituindo mesmo as categorias "homem" e "mulher" no sentido moderno. Nessa construção, a fraqueza e a passividade sexual são características cruciais às fêmeas burguesas brancas, tidas como reprodutoras da classe e da posição racial e colonial dos homens brancos burgueses. Em relação a estas mulheres, tão importante quanto a função de reprodutora da propriedade e da raça, foi sua exclusão das esferas da autoridade coletiva, da produção de conhecimento e da possibilidade de controle sobre os meios de produção. A socialmente construída fraqueza de seus corpos e suas mentes cumpre um papel fundamental na redução e reclusão destas mulheres em relação à maior parte dos domínios da vida.

O lado oculto/obscuro desse sistema de gênero, segundo Lugones, está na construção diferencial do gênero em termos raciais. De acordo com a autora, isto significa dizer que o gênero não pode ser pensado apenas na construção e controle sobre o sexo, seus recursos e produtos, mas também sobre o trabalho como racializado e engenerizado simultaneamente. Ela defende que é preciso reconhecer uma articulação entre o trabalho, o sexo e a colonialidade do poder, pois só assim é possível entender o “alcance do sistema de gênero 
moderno/colonial na construção da autoridade coletiva, de todos os aspectos da relação entre capital e trabalho e na construção do conhecimento" (p. 99).

Lugones (2008), em certa medida, compartilha dos pensamentos Rich (2010) e Wittig (1992) de que heterossexualidade é um sistema político e não apenas sexual, não sendo simplesmente biologizada de uma maneira fictícia, mas obrigatória. Para ela, este sistema heterossexual obrigatório permeia a totalidade da "colonialidade do gênero" e no sistema de gênero moderno/colonial tem sido coerente e profundamente perversa, violenta, degradante.

No entanto, considerando a colonialidade do poder e a imbricação dos sistemas de dominação, Lugones aponta que os diferentes modos como a heterossexualidade compulsória incide nos distintos grupos raciais não pode ser ignorado nem colocado como secundário. $\mathrm{Na}$ sua perspectiva, a heterossexualidade como regime político na modernidade/colonialidade tem “convertido as pessoas 'não brancas' em animais e as mulheres brancas em reprodutoras Da Raça (branca) e Da Classe (burguesa)” (LUGONES, 2008, p. 92).

Kilomba (2019) considera que a ordem colonial institui realidades bastante distintas tanto entre mulheres negras e mulheres brancas quanto entre homens negros e homens brancos. De acordo com ela, neste cenário, os status das mulheres brancas e dos homens negros podem ser reconhecidos como oscilantes. As primeiras, por fazerem parte do grupo racial dominante, ainda que sexualmente sejam subordinadas, ocupam posição de dominação/agente de opressão no âmbito racial. Os segundos, por sua vez, são subalternizados pela raça, mas em determinados aspectos e contextos ocupam posição de agentes de opressão sexista. Neste sentido, pensar as categorias "homem" e "mulher" como universais impossibilita o desenvolvimento de análises que deem conta da complexa teia de opressões que incidem sobre os corpos-vidas na modernidade/colonialidade.

Kilomba afirma que tanto a categoria "gênero" quanto a categoria "raça" são insuficientes, por tratarem de formas de opressão distintas (racismo, sexismo e lesbofobia) como cumulativas, quando na verdade estão interseccionadas. A autora frisa que as intersecções das opressões "não podem ser vistas como uma simples sobreposição de camadas, mas sim como a 'produção de efeitos 
específicos' (Anthias e Yuval-Davis, 1992, p. 100). Formas de opressão não operam em singularidade; elas se entrecruzam" (2019, p. 98). Aqui vemos que a compreensão de intersecção trazida por Kilomba se aproxima com a noção de imbricação trazida por Curiel $(2009 ; 2016)$. A autora aponta que:

Pode-se argumentar que, como processos, o racismo e o sexismo são semelhantes, pois constroem ideologicamente o senso comum através da referência às diferenças "naturais" e "biológicas". No entanto, não podemos entender de modo mecânico o gênero e a opressão racial como paralelos porque ambos afetam e posicionam grupos de pessoas de forma diferente e, no caso das mulheres negras, eles se entrelaçam. Na tentativa de comparar o sexismo e o racismo, as feministas brancas esquecem de conceituar dois pontos cruciais. Primeiro, que elas são brancas e, portanto, têm privilégios brancos. Esse fator torna impossível a comparação de suas experiências às experiências de pessoas negras. E, segundo, que as mulheres negras também são mulheres e, portanto, também experimentam o sexismo. Uma falha irônica, porém trágica, que teve como resultado a invisibilização e o silenciamento de mulheres negras dentro do projeto feminista global (KILOMBA, 2019, p. 100).

Ao considerar a imbricação dos sistemas de opressão - gênero, raça e classe - na modernidade/colonialidade, pensadoras negras e decoloniais admitem a multiplicidade e complexidade da experiência de ser mulher. $\mathrm{O}$ que essas pensadoras apontam, dentre outras questões, é que, no sistema capitalista moderno/colonial, sobre os corpos de mulheres negras e não brancas, especialmente das classes econômicas mais baixas, incide um tipo de violência patriarcal-racista-capitalista-colonial que as subalterniza em um nível qualitativamente diferenciado do que o das mulheres brancas burguesas, fixandoas em posições mais vulneráveis em termos de subordinação e exploração. Neste sentido, apontam que gênero, raça, sexualidade e classe não podem ser analisados separadamente (CURIEL, 2009; LUGONES, 2008; CARNEIRO, 2011; HOOKS, 2019).

A intenção disso não é, como aponta hooks (2019), dissuadir as pessoas não brancas de se engajarem no feminismo, pois é reconhecido que a luta contra a dominação patriarcal é uma luta fundamental para todas/os. Mas esse reconhecimento não se dá a partir da ideia de que essa dominação seja a base de todas as outras estruturas opressivas e sim por ser uma forma de dominação com a qual todas nós estamos sujeitas a viver de modo permanente na vida cotidiana, nas nossas relações privadas, íntimas, familiares. 
No entanto, para que essa luta de fato contemple a todas as mulheres, é fundamental compreender que "a dominação patriarcal compartilha um base ideológica com o racismo e outras formas de opressão de grupos, que não há esperança de que seja erradicada enquanto esses sistemas permanecerem intactos" (HOOKS, 2019, p. 62). De acordo com hooks, esse reconhecimento deve guiar a teoria e a prática feministas:

[...] é necessário agora que pensadoras feministas critiquem e revisem a teoria feminista e a direção do movimento feminista. Esse esforço de revisão é talvez mais evidente no reconhecimento amplo e constante de que machismo, racismo e exploração de classe constituem sistemas interligados - de que sexo, raça e classe, e não somente sexo, determinam a natureza da identidade, do status e da circunstancia de qualquer mulher, o grau em que ela será ou não dominada, o quanto ela terá ou não poder para dominar (HOOKS, 2019, pp. 62-63).

O que essas pensadoras analisam é que, no sistema de gênero moderno/colonial instituído, o controle patriarcal das capacidades sexuais e reprodutivas das mulheres se atrela ao racismo e a exploração de classe, produzindo diferenciações nos modos como incide sobre os corpos-vidas dos diferentes grupos de mulheres. Essas diferenciações produzem hierarquias na própria classe de mulheres, fazendo que no interior desta se estabeleçam relações de dominação (racial e de classe) entre as mulheres. É neste sentido que defendem que a subordinação das mulheres não pode ser analisada a partir apenas do gênero e da hierarquia sexual por ele produzida, mas destes na relação com outros sistemas de dominação modernos/coloniais.

\subsection{Imbricações e hierarquias na classe de mulheres}

$\mathrm{Na}$ análise das imbricações dos sistemas de dominação coloniais, podemos considerar a perspectiva trazida por Carneiro (2011) sobre o mito da fragilidade feminina como um exemplo de como o "gênero" quando imbricado a "raça" produz alterações nos efeitos de poder sobre corpos-sexuados-em-mulher. Esta autora aponta que o feminino frágil, atribuído pelo gênero aos sujeitos ele institui como do "sexo feminino" para justificar uma necessária proteção paternalista sobre as mulheres, não é uma realidade para mulheres negras:

Nós, mulheres negras, fazemos parte de um contingente de mulheres, provavelmente majoritário, que nunca reconheceram em si mesmas esse mito, 
porque nunca fomos tratadas como frágeis. Fazemos parte de um contingente de mulheres que trabalharam durante séculos como escravas nas lavouras ou nas ruas, como vendedoras, quituteiras, prostitutas... Mulheres que não entenderam nada quando as feministas disseram que as mulheres deveriam ganhar as ruas e trabalhar! Fazemos parte de um contingente de mulheres com identidade de objeto. Ontem, a serviço de frágeis sinhazinhas e de senhores de engenho tarados [...] Hoje, empregadas domésticas de mulheres liberadas e dondocas, ou de mulatas tipo exportação [...] Quando falamos em romper com o mito da rainha do lar, da musa idolatrada dos poetas, de que mulheres estamos falando? As mulheres negras fazem parte de um contingente de mulheres que não são rainhas de nada, que são retratadas como antimusas da sociedade brasileira, porque o modelo estético de mulher é a mulher branca (CARNEIRO, 2011, s/p).

Carneiro aponta que, no Brasil e na América Latina todas as construções de identidade nacional e a estruturação do "mito da democracia racial" (NASCIMENTO, 1978), se originam da violação sexual colonial praticada pelos exploradores europeus brancos contra as mulheres indígenas e negras e a miscigenação resultante dessa violência. Como aponta Carneiro (2019), “a expressiva massa de população mestiça construída na relação subordinada de mulheres escravas negras e indígenas com seus senhores tornou-se um dos pilares estruturantes da decantada 'democracia racial' brasileira”' (p. 151).

A ideia de democracia racial, racionalizada teoricamente por Gilberto Freyre, em 1933, na obra "Casa-Grande e Senzala", difundiu a ideia de que no Brasil as relações inter-raciais se constituíram de modo não segregacionista. De acordo com Freyre (1969), isto se deu porque o processo de colonização promoveu uma grande miscigenação entre brancos europeus, ameríndios e negros africanos, criando um povo único que convive harmoniosamente e desfruta das mesmas oportunidades.

A rigor, democracia racial significa "um sistema racial desprovido de qualquer barreira legal ou institucional para a igualdade racial e, em certa medida, um sistema racial desprovido de qualquer manifestação de preconceito ou discriminação" (DOMINGUES, 2005, p. 116). Mas o professor, artista e ativista do movimento negro brasileiro, Abdias do Nascimento (1978) é categórico ao afirmar ela não passa de um mito que designa perfeitamente o racismo à brasileira:

não tão óbvio como o racismo dos Estados Unidos e nem legalizado qual o apartheid da África do Sul, mas eficazmente institucionalizado nos níveis oficiais de governo assim como difuso no tecido social, psicológico, econômico, político 
e cultural da sociedade do país. Da classificação grosseira dos negros como selvagens e inferiores, ao enaltecimento das virtudes da mistura de sangue como tentativa de erradicação da "mancha negra"; da operatividade do "sincretismo" religioso; à abolição legal da questão negra através da Lei de Segurança Nacional e da omissão censitária - manipulando todos esses métodos e recursos - a história não oficial do Brasil registra o longo e antigo genocídio que se vem perpetrando contra o afro-brasileiro. Monstruosa máquina ironicamente designada "democracia racial" que só concede aos negros um único "privilégio": aquele de se tornarem brancos, por dentro e por fora. A palavra - senha desse imperialismo da brancura, e do capitalismo que lhe é inerente, responde a apelidos bastardos como assimilação, aculturação, miscigenação; mas sabemos que embaixo da superfície teórica permanece intocada a crença na inferioridade do africano e seus descendentes (p. 93).

Compartilhando do pensamento de Nascimento, Gonzalez (1984) compreende que o racismo é "a sintomática que caracteriza a neurose cultural brasileira" (p. 224), sendo a sua articulação com o sexismo produtora de efeitos particularmente violentos sobre a mulher negra. Segundo a autora, ao nos debruçarmos sobre determinados aspectos da denominada cultura brasileira percebemos "que em suas manifestações mais ou menos conscientes ela oculta, revelando, as marcas da africanidade que a constituem” (p. 226), dentre as quais "o lugar da mulher negra nesse processo de formação cultural, assim como os diferentes modos de rejeição/integração de seu papel" (idem).

Gonzalez traz a imagem do rito carnavalesco como aquela em que o mito da democracia racial brasileira é atualizado com toda a sua força simbólica, deflagrando o exercício de sua violência de maneira especial sobre a mulher negra. Para a autora, é nesse instante que a mulher negra transforma-se exclusivamente na rainha - "ela perde seu anonimato e se transfigura na Cinderela do asfalto, adorada, desejada, devorada pelo olhar dos príncipes altos e loiros, vindos de terras distantes só para vê-la" (GONZALEZ, 1984, p. 228).

Mas o outro lado do endeusamento carnavalesco da mulher negra ocorre em seu cotidiano, quando ela se transfigura a empregada doméstica. "É por aí que a culpabilidade engendrada pelo seu endeusamento se exerce com fortes cargas de agressividade" quando "se constata que os termos mulata e doméstica são atribuições de um mesmo sujeito" (idem). É a situação em que são vistas que determinará a nomeação.

De acordo com Gonzalez, foi na figura da mucama que o engendramento da mulata e da doméstica se fez. A mucama é retratada pelo discurso histórico 
oficial como aquela escrava negra moça que foi escolhida para o trabalho doméstico. No entanto, seu significante proveniente da língua quimbundo (mu'kama) quer dizer 'amásia escrava'.

Gonzalez aponta que, na sociedade escravocrata, a função da escrava no sistema produtivo (prestação de bens e serviços) esta articulada com a prestação de serviços sexuais. O ocultamento desta função da mucama perpetrado pela história oficial, no entanto, não significa seu desaparecimento. Para a autora, é o momento privilegiado em que sua presença se torna manifesta na exaltação mítica da mulata no entre parênteses que é o carnaval, que atualiza a figura da mulher negra como "portadora de qualidades intrínsecas passíveis de manipulação em rituais de sedução do homem branco" (GIACOMINI, 1994, p. 100).

Como demonstra a matéria do Portal Geledés ${ }^{46}$ intitulada "Transou com a empregada: por que não se fala de abuso sexual com domésticas", escrita por Willian Novaes (2019), o assédio e o abuso sexual contra empregadas domésticas existem e persistem há séculos. São atualizações do que acontecia com as mucamas no período escravocrata, como analisou Gonzalez (1984). De acordo com Novaes, "a situação é tão normalizada que há alguns homens que exibem as suas experiências sexuais com as funcionárias, como troféus em conversas masculinas" (2019, s/p).

Essa matéria, que traz o depoimento de diversas trabalhadoras domésticas, ressalta a invisibilidade social desta problemática. A matéria conta com a fala da presidente do Sindicato das Trabalhadoras Domésticas de São Paulo, Janaina Souza, que denuncia a falta de pesquisa e produção teórica sobre este assunto. Ela atribui isto, em partes, a dificuldade das próprias trabalhadoras domésticas de revelarem os assédios, afirmando que "a incerteza da punição dos estupradores é o maior medo das mulheres abusadas".

Mas também poderíamos pensar que o pouco interesse dos/as acadêmicos/as em relação a essa temática está ligado a própria branquitude sexista

\footnotetext{
${ }^{46}$ O Portal Geledés é o espaço de expressão pública das ações realizadas pela organização GELEDÉS Instituto da Mulher Negra no passado e no presente, e de seus compromissos políticos com a defesa da cidadania e dos direitos humanos, a denúncia dos entraves que persistem para a concretização da justiça social, a igualdade de direitos e oportunidades em nossa sociedade.
} 
acadêmica, que não quer tratar de temas que denunciam sua própria violência. Afinal, na casa de quem acontecem esses abusos?

Janaina também denuncia que mesmo quando as trabalhadoras domésticas tomam coragem de falar para a esposa do abusador, normalmente "perdem o emprego e ainda são taxadas de mentirosas". Este relato nos leva a problematizar as relações de opressão históricas que atravessam as relações entre mulheres brancas e negras em nossa sociedade e que também é atualizada na figura da empregada doméstica.

Como, ainda na matéria do Portal Geledés, aponta a antropóloga pesquisadora do tema Valeria Riberio Corozzacz:

Não se trata apenas de uma violência sexista, mas também de uma violência racista e de classe, considerando que, como podemos verificar, nela se combinam as diferenças de raça, de classe e de sexo, típicas da sociedade brasileira. Isso produz formas determinadas de opressão e de privilégio social (NOVAES, 2019, $\mathrm{s} / \mathrm{p})$.

Em relação ao trabalho, dialogando com Catharine A. MacKinnon, Rich (2010) delineia a interface da heterossexualidade compulsória com a economia capitalista, afirmando que neste sistema as mulheres são segregadas e ocupam uma posição inferior estrutural no ambiente de trabalho. MacKinnon explica que o porquê das pessoas recrutadas para posições mal pagas e de baixo status serem do sexo feminino está no fato de que a sexualização das mulheres faz parte do trabalho.

Central e intrínseca às realidades econômicas das vidas das mulheres é a exigência de que elas irão "comercializar atratividade sexual para os homens, que tendem a manter o poder e a posição econômica para garantir suas predileções". MacKinnon registra que o "assédio sexual perpetua a estrutura por meio da qual as mulheres têm sido mantidas em servidão para os homens na base do mercado de trabalho". Assim, as mulheres no mercado de trabalho ficam à mercê do sexo como poder em um círculo vicioso. Economicamente em desvantagem, as mulheres, sejam garçonetes, sejam professoras titulares, toleram o assédio sexual para se manter em seus empregos e aprendem a se comportar de uma maneira heterossexual complacente e agradável porque elas descobrem que essa é sua verdadeira qualificação para ter emprego, qualquer que seja o tipo de emprego (RICH, 2010, p. 28).

Para Rich, o local de trabalho é um dos muitos lugares aonde mulheres vão, para sua sobrevivência, aprendendo a aceitar a violação masculina, tanto física quanto psicológica, e se perceberem como presas sexuais. Mas pensando a 
imbricação sexismo-racismo, percebemos que há especificidades desta dinâmica de poder na vida das mulheres não brancas que extrapolam a violência masculina. Isto fica evidente nos relatos das entrevistadas na matéria do Portal Geledés, acima citada, que deflagram inclusive a violência e/ou cumplicidade das "patroas" com as violências e violações sofridas por mulheres trabalhadoras das classes raciais e econômicas subalternizadas dentro e fora do seu local de trabalho.

Como aponta Gonzalez, a doméstica é a mucama permitida, “o burro de carga que carrega sua família e a dos outros nas costas” (1984, p. 230). E é a negra anônima, habitante da periferia, quem sofre mais drasticamente os efeitos da terrível culpabilidade branca. Justamente por ser ela que sobrevive na base da prestação de serviços. Mulher que não raro sustenta sozinha a família, muitas vezes "porque seu homem, seus irmãos ou seus filhos são objeto de perseguição policial sistemática" (p. 231).

Muito diferente do que é defendido pela ideia de "democracia racial", a constituição da população brasileira se dá através do duro encontro entre diversas etnias indígenas nativas sobreviventes e africanas/os (sequestradas/os de sua terra natal para serem aqui escravizadas/os) com os brancos colonizadores europeus e por estes transformadas em "Outras/os". O que somos hoje em termos de população é fruto deste encontro, que longe de qualquer romantismo e harmonia, foi marcado pela brutal violência perpetrada contra povos indígenas e africanos em geral, e pela violência sexual sofrida por mulheres negras e indígenas em particular, como assinalado por Carneiro (2011). Estupros e exploração das capacidades reprodutivas e sexuais de mulheres é o que encontramos quando desromantizamos a miscigenação e desmistificamos a suposta democracia racial.

É, portanto, na sociedade colonial escravista que se constrói o persistente mito da mulher quente, sexualmente disponível, atribuído às mulheres negras e as "mulatas", difundido pela tradição oral e no meio intelectual através da literatura. Em um período em que estas mulheres viviam em uma condição de objeto, pois eram propriedades dos senhores que as compravam - a condição de subordinação as obrigava a atender a todos os desejos dos senhores - independente da sua vontade e consentimento. Ao mesmo tempo, às mulheres negras consideradas 
como destituídas dos atrativos sexuais, reservava-se a condição de "burro de carga", que persiste ao longo da história na figura da doméstica.

A definição de gênero/raça instituída pelo sistema capitalista moderno/colonial para as mulheres brasileiras era, como aponta Carneiro: "Preta pra trabalhar, branca pra casar e mulata para fornicar”. Uma definição que, além de "estigmatizar mulheres em geral, ao hierarquizá-las do ponto de vista do ideal patriarcal de mulher, introduz contradições no interior do grupo feminino" (CARNEIRO, 2019, p. 156).

De acordo com Carneiro (2019), a persistência desses paradigmas coloniais no pós-abolição teve um impacto muito negativo na construção de uma perspectiva unitária de luta das mulheres por emancipação. Ela culmina na transformação do movimento feminista "em um campo de batalha no qual ressentimentos seculares decorrentes dos privilégios e opressões determinados por esses estereótipos se defrontarão de formas às vezes dramáticas" (CARNEIRO, 2019, p. 156).

bell hooks ${ }^{47}$ (2013), professora e feminista negra norte-americana, analisou de modo profundo e sensível os impactos da persistência dos paradigmas racistas na relação entre mulheres negras e brancas e, consequentemente, na luta das mulheres por emancipação social na sociedade norte-americana. Apesar das especificidades da realidade de cada contexto, compreendemos que as considerações trazidas por hooks contribuem imensamente para a análise das relações estabelecidas entre mulheres de diferentes grupos raciais no sistema capitalista moderno/colonial instituído, especialmente em países que, como o Brasil, também têm sua história marcada por um longo período de vigência de sistemas escravocratas racistas-patriarcais.

Para hooks, as discussões atuais acerca dos relacionamentos entre mulheres negras e brancas precisam levar em conta o ressentimento das negras escravizadas em relação às brancas.

Elas tinham um ressentimento compreensível e uma raiva reprimida da opressão racial, mas magoavam-se primeiramente pela esmagadora ausência de compaixão

\footnotetext{
${ }^{47}$ hooks prefere que seu nome seja escrito em minúsculo para que a atenção seja concentrada em sua mensagem ao invés de em si mesma.
} 
das mulheres brancas não só em circunstâncias que envolviam abuso sexual e físico das negras como também situações em que crianças negras eram separadas de suas mães escravas. Mais uma vez, era nessa esfera dos interesses que ambas tinham (mulheres brancas conheciam o horror do abuso sexual e físico bem como a profundidade do apego da mãe a seus filhos) que a maioria das mulheres brancas poderia ter se identificado por meio da empatia voltava as costas para a dor das mulheres negras (p. 131).

Retomando memórias de sua adolescência, em uma cidade do sul dos Estados Unidos racialmente segregada nos anos 60, hooks conta que, na vida cotidiana, era evidente a existência de barreiras sólidas de divisão entre o grupo de mulheres negras e o de mulheres brancas, inviabilizando relações de amizade reais entre elas. A autora observa que havia nessas relações um atravessamento da relação hierárquica serva-senhora que persistia.

Essa relação se estabelecia na esfera doméstica, em um contexto em que acreditava-se que era papel da mulher, tanto branca quanto negra, cuidar da casa. Mas se dentro das normas sexistas havia uma semelhança entre suas posições, "o contato pessoal entre os dois grupos era cuidadosamente construído de forma a reforçar a diferença de status baseada na raça” (HOOKS, 2013, p. 128).

Para hooks, ao longo da história, o esforço das mulheres brancas para manter a dominação racial tem ligação direta com a política do heterossexismo dentro de um patriarcado supremacista branco. Era em defesa de sua frágil posição social e seu poder que mulheres brancas afirmavam sua superioridade sobre mulheres negras. De certo modo, aqui podemos perceber como hooks, mesmo sem utilizar esta expressão, traz em sua análise a imbricação dos sistemas de opressão.

Pelos vínculos raciais, as normas sexistas, que instituíam a subordinação das mulheres brancas em razão de seu sexo, podiam ser mediadas. Desta maneira, a preservação da separação de status muito evidente entre brancas e negras era vista pelas brancas como essencial para garantir a manutenção de sua posição. Neste contexto, o pacto com o racismo era fundamental, pois defendendo e reforçando os tabus raciais que proibiam as relações legais entre os dois grupos raciais, mantinha-se as negras à distância, diminuindo a concorrência no mercado sexual. Tal percepção, no entanto, desconsiderava que a maior parte dessas relações se dava através da violência (coerção e estupro). 
Enquanto uniões sexuais entre negras e brancos acontecessem num contexto não legalizado e numa estrutura de sujeição, coerção e degradação, a cisão entre o status de "madames" das mulheres brancas e a representação das negras como "prostitutas" podia se manter. Assim, os privilégios de raça e classe das mulheres brancas eram reforçados pela manutenção de um sistema em que negras eram objetos de sujeição e abuso por parte de homens brancos (HOOKS, 2013, pp. 130-131).

De acordo com hooks, o fim do regime escravocrata não significou uma mudança real na relação hierárquica estabelecida entre mulheres brancas e negras. Sem a estrutura escravocrata, que institucionalizava as diferenças entre brancas e negras, as brancas recorreram ainda mais aos tabus sociais para promover sua superioridade racial e manter a proibição de relações legalizadas entre as raças posicionamento que contribuiu enormemente para perpetuação dos ataques e estereótipos degradantes sobre a feminilidade negra.

De acordo com hooks, na nova configuração social a única vantagem adquirida pelas mulheres negras era a de poderem voltar para casa. No entanto, se nas circunstâncias sociais da escravidão, por vezes as senhoras brancas, por ligações afetivas ou preocupação materiais, adentravam no local de residência das mulheres negras, fazendo com que, em alguma medida, pudessem conhecer uma esfera da experiência dessas mulheres para além da relação entre serva e senhora, enquanto empregadora branca, isso não mais acontecia.

hooks ressalta que um ponto crucial para avançarmos na análise crítica das relações entre mulheres negras e brancas é tirar do foco a questão da existência ou não de afetividade entre empregadas negras e patroas brancas. Ela propõe que devemos partir da perspectiva de que o contexto de exploração, não impede o surgimento de laços de carinho em face da dominação - como é o caso do carinho existente em relacionamentos heterossexuais em que, no sistema social em que vivemos, mulheres estão subordinadas aos homens. Assim, as empregadas que as mulheres brancas consideram como "parte da família", muitas vezes tem uma visão completamente diferente dessa relação, "a empregada poderá ter a permanente consciência de que nenhum grau de afeto e carinho elimina as diferenças de status - ou a realidade de que brancas exerciam o poder, quer de modo benevolente, quer de maneira tirânica” (2013, pp. 133-134). 
hooks defende que, se quisermos compreender as relações contemporâneas, necessariamente precisaremos explorar o impacto dos encontros entre mulheres negras e brancas "sobre a percepção global que as negras têm das brancas” (p. 135). Uma percepção que é passada de geração em geração, de modo que mesmo as negras que nunca foram empregadas têm algumas ideias acerca das brancas herdadas de suas parentes que moldam suas expectativas e interações.

Muitas negras que trabalharam como empregadas em lares brancos, particularmente na época em que as mulheres brancas não trabalhavam fora, entendem que as brancas mantém uma postura egocêntrica e infantil de inocência e irresponsabilidade à custa das mulheres negras. Observa-se repetidamente que o grau com que as mulheres brancas são capazes de se afastar da realidade doméstica, das responsabilidades de cuidar das crianças e do serviço doméstico é determinado pela medida em que as negras, ou algum grupo subprivilegiado, estão amarradas a esse trabalho, obrigadas pelas circunstâncias econômicas a aparar as arestas, a assumir a responsabilidade (HOOKS, 2013, p. 136).

hooks então considera que enquanto as mulheres brancas não forem capazes de encarar de maneira crítica seu medo e ódio das mulheres negras, assim como o medo e ódio das mulheres negras em relação a elas, reconhecendo a história negativa que molda estas interações ao longo do tempo, o diálogo honesto e potente entre os dois grupos não será possível. Para a autora, o apelo do feminismo à irmandade feminina, ainda que parta de um desejo sincero de criar um novo contexto de vinculação, não ocorrerá se não incluir a tentativa de assimilar a história ou as barreiras que dificultam essa vinculação.

No entanto, segundo hooks, isso não pode se dar pela mera apropriação das discussões sobre raça e racismo, mas do "esforço para construir um espaço onde possam examinar e modificar suas atitudes e comportamentos perante as mulheres negras e todas as mulheres de cor" (HOOKS, 2013, p. 140). Este alerta é feito por observar que muitas mulheres brancas que, com a institucionalização e profissionalização do trabalho feminista voltado a construção teórica e difusão do feminismo, passam a assumir posições de poder, tendem a atualizar o paradigma racial hierárquico. Tal atualização se dá na medida em que colocam mulheres negras na posição daquelas que atendem ao seu desejo de "dominar" o tema da raça e do racismo. Ao mesmo tempo, não cogitam colocar o "ser branca" em questão. 
Foram o medo e a raiva do confisco de suas histórias e análises junto a preocupação de não serem cúmplices da reprodução da relação serva-senhora que, segundo hooks, fizeram com que as mulheres negras abandonassem os ambientes feministas embranquecidos. Mas, na visão da autora, tal abandono não apenas não soluciona o problema como o agrava. Isto porque, sem que as vozes das mulheres negras apareçam, suas preocupações não são formuladas, seguindo silenciadas.

hooks salienta que, ainda que raros, os encontros positivos entre mulheres dos dois grupos acontecem e não devem ser ignorados. A partir da escuta de mulheres negras, a autora aponta que os fatores que distinguem as relações que mulheres negras têm com feministas brancas que não consideram exploradoras ou opressoras são principalmente "a confrontação sincera e o diálogo a respeito da raça; e a interação recíproca" (p. 143).

Seguindo nessa mesma direção, Carneiro (2019) considera que o caminho para lidar com esses conflitos de modo a viabilizar um diálogo mais solidário entre os grupos de mulheres é admitir as diferenças. É compreender, por exemplo, que a experiência histórica de mulheres negras carrega especificidades que diferenciam qualitativamente os modos e efeitos da opressão por elas vividas daqueles apresentados pelo discurso clássico sobre a opressão da mulher. Isto porque, como vimos, tais opressões incidem sobre os corpos-vidas das mulheres indissociadas das opressões racistas e classistas, o que produz violências específicas e mesmo dissonantes em determinados aspectos das voltadas aos corpos-vidas das mulheres dependendo da classe racial e econômica as quais pertencem.

Assim, se as análises sobre as opressões patriarcais não consideram tais especificidades, acabam por reproduzir a lógica racista, ocultando mais uma vez a perspectiva embranquecida do discurso clássico sobre a opressão das mulheres. Tal perspectiva, invisibiliza mulheres negras e não brancas, especialmente das classes econômicas mais baixas, colocando-as, desta maneira, a margem das ações de combate às opressões sexistas.

O que tanto Carneiro quanto hooks nos levam a perceber é que é precondição para estabelecer relações de igualdade que mulheres brancas 
assumam a responsabilidade por analisar criticamente suas próprias reações à questão da raça. Isto é, se quisermos uma aproximação verdadeira com mulheres subalternizadas pelo racismo é preciso que criemos uma consciência crítica sobre os pressupostos racistas naturalizados e com os quais precisamos sempre lidar, no sentido de combatê-los. Como compartilha hooks, "o grau em que uma mulher branca é capaz de aceitar a verdade da opressão racista - da cumplicidade das mulheres, dos privilégios que elas recebem numa estrutura racista - determina a medida com que é capaz de ter empatia com mulheres de cor” (p. 144).

Como defende Carneiro (2011), em sociedades como as latino-americanas - pluriculturais e racistas - a unidade na luta das mulheres para além da capacidade de superar as desigualdades geradas pela histórica hegemonia masculina, exige ainda a superação outros sistemas de opressão, como, por exemplo, o racismo. É nesta perspectiva que "a luta das mulheres negras contra a opressão de gênero e de raça vem desenhando novos contornos para a ação política feminista e antirracista" (CARNEIRO, 2011).

\subsection{O sentido de "ser branca": a branquitude em questão}

É verdade que não nascemos racistas. Afinal, o racismo não é natural, mas uma construção histórica (MOORE, 2007). No entanto, é também verdade que nascer branca/o em uma sociedade estruturada historicamente pelo racismo, é crescer racista.

Como afirma Foucault (2001), o sujeito é aquilo que "se constitui no interior mesmo da história, e que é a cada instante fundado e refundado pela história" (p. 7). Neste sentido, a subjetividade é um composto histórico, produto de relações de poder, que se transforma na medida em que vai sendo atravessado pelos enunciados de cada época e lugar. São formas de agir, pensar e sentir o mundo, fabricadas pelos dispositivos sociais, políticos, culturais, econômicos existentes em cada sociedade. Ou como diz Machado (1999):

$\mathrm{O}$ que acreditamos ser nossa personalidade, nosso mais íntimo desejo, são expressões-em-nós da história de nossa época. [...] Nós somos atravessados por toda uma complexa teia de aspectos desejantes, políticos, econômicos, científicos, tecnológicos, familiares, culturais, afetivos, televisivos... Entretanto, cada um de nós tem uma história de vida que é singular e que não é interior. É como se 
inúmeras peças de um jogo se embaralhassem de formas variadas e com intensidades distintas, fazendo com que afirmássemos essa composição como sendo nosso eu ou nossa individualidade. Mas em cada momento histórico as peças se modificam, algumas se introduzem, algumas se mantêm e outras vão sendo esquecidas. Experimentamos a composição de algumas delas ao longo de nossa vida e muitas vezes, querendo ou não, elas se embaralham e assumem outras formas (p. 4).

Foi analisando politicamente minha trajetória pessoal - possível a partir principalmente das leituras de importantes análises críticas sobre a raça, gênero e classe - que pude perceber como o racismo estruturante atravessa e constitui não apenas as instituições, mas também os sujeitos. Se olharmos com atenção, notamos que o processo de produção de subjetividade de pessoas brancas é fundamentado pelo racismo. E isto faz com que todas estas pessoas, conscientemente ou não, sejam sim racistas, pelo simples (e tão complexo) fato de que desde muito cedo aprendemos que ver e operar no mundo sob essa lente nos traz vantagens.

Cresci em Niterói, mas nasci no interior da Bahia, num hospital de uma cidade chamada Itabuna, vizinha da cidade de Una, onde meus pais e meu irmão mais velho moravam naquela época. Dentre as histórias que ouvi sobre o tempo em que moramos na Bahia, uma das mais repetidas nos encontros familiares era a do meu nascimento. Dois momentos eram sempre enfatizados. O primeiro era o do conflito do meu pai com as freiras que gerenciavam o hospital, quando estas o impediram, por ser homem, de acompanhar minha mãe na sala de parto. O segundo era o momento em que as pessoas iam me conhecer no berçário. Este era narrado por muitos familiares destacando o quanto eu, em meio aos demais bebês baianos, "brilhava" (sic.). Segundo alguns, as pessoas do hospital iam até a maternidade para ver aquela "bebê reluzente" (sic.), tão diferente do que estavam acostumados a ver por ali. O fato de eu ter nascido na Bahia sempre foi tratado com "humor" pela minha família em função de, na visão deles, eu ser "clara demais para uma baiana" (sic.). Discursos que hoje percebo terem tido um peso considerável na construção da minha autoimagem desde tenra idade. Uma autoimagem que não é meramente individual, mas que se constrói em meio a relações de poder e nos posiciona no mundo. Isto é, que pauta nossos modos de ver o mundo, as pessoas e de estabelecer relações. 
Não cheguei a frequentar a escola na Bahia e tenho pouquíssimas lembranças desse período. Mas, em Niterói, minhas primeiras lembranças da vida escolar são da educação infantil, que cursei em uma tradicional escola católica particular da cidade, localizada em um bairro nobre, próxima a casa da minha avó paterna, que era coordenadora pedagógica da escola e por isso eu tinha uma bolsa de estudos. Minha avó era uma mulher branca que fazia parte do seleto grupo de mulheres da sua geração que cursaram e concluíram uma faculdade.

Minhas memórias dessa época também não são muitas. Mas, há pouco tempo, quando já havia começado esta pesquisa, encontrei em umas caixas guardadas na casa da minha mãe uma fotografia deste período. $\mathrm{Na}$ foto, eu tinha por volta de 4 anos e aparecia vestida com trajes e adereços que faziam alusão aos usados por mulheres adultas brancas burguesas no período colonial.

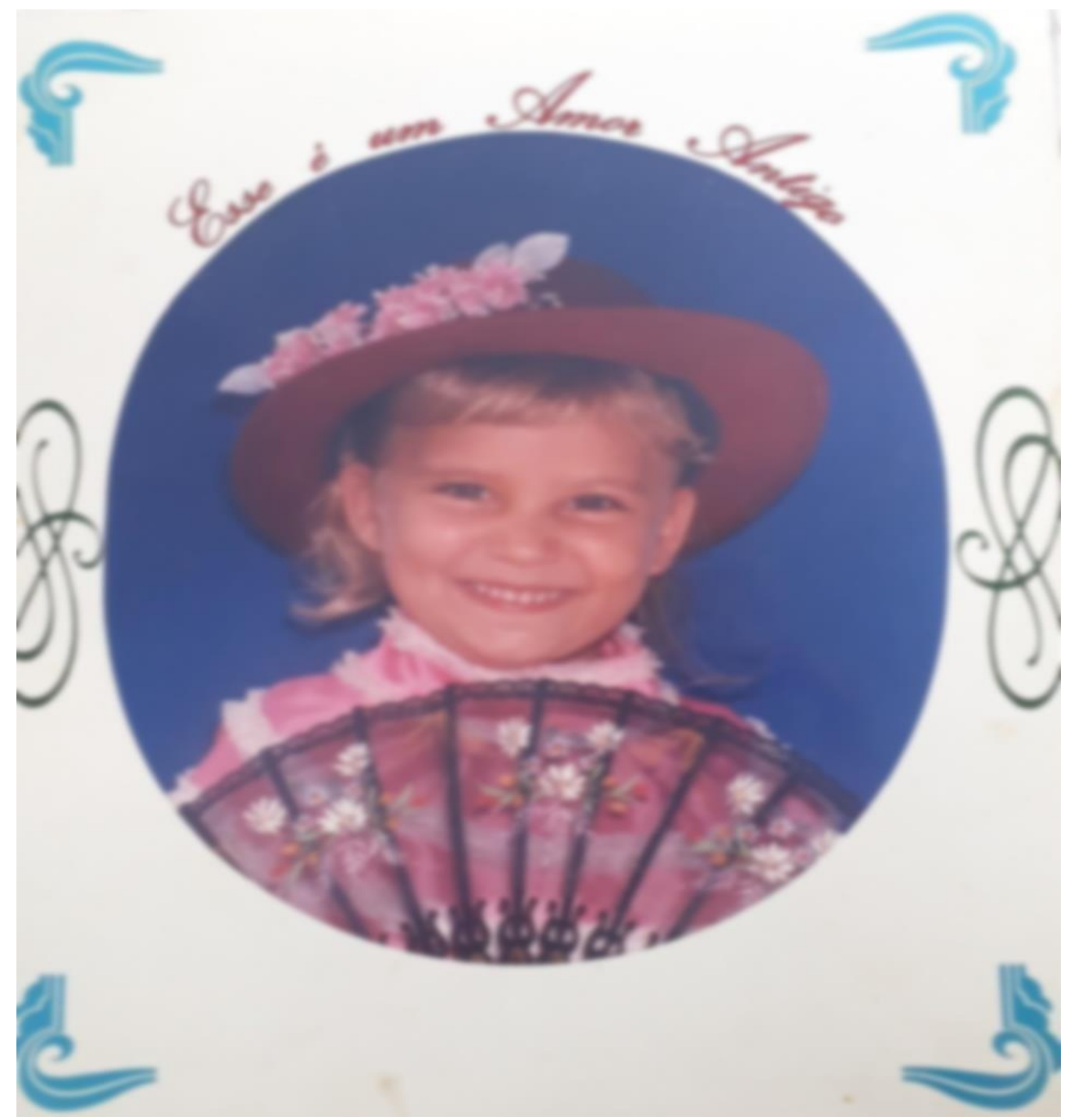

Figura 1. Arquivo pessoal foto escolar 
Na mesma caixa, havia outra fotografia do mesmo tipo, também tirada como uma recordação escolar de outra escola particular (mas não tradicional, nem religiosa) na qual estudei quando tinha aproximadamente 6 anos de idade. Desta vez, o registro foi feito junto com meu irmão mais novo e nós dois aparecíamos com as vestes de mulheres e homens adultos brancos burgueses do período colonial.

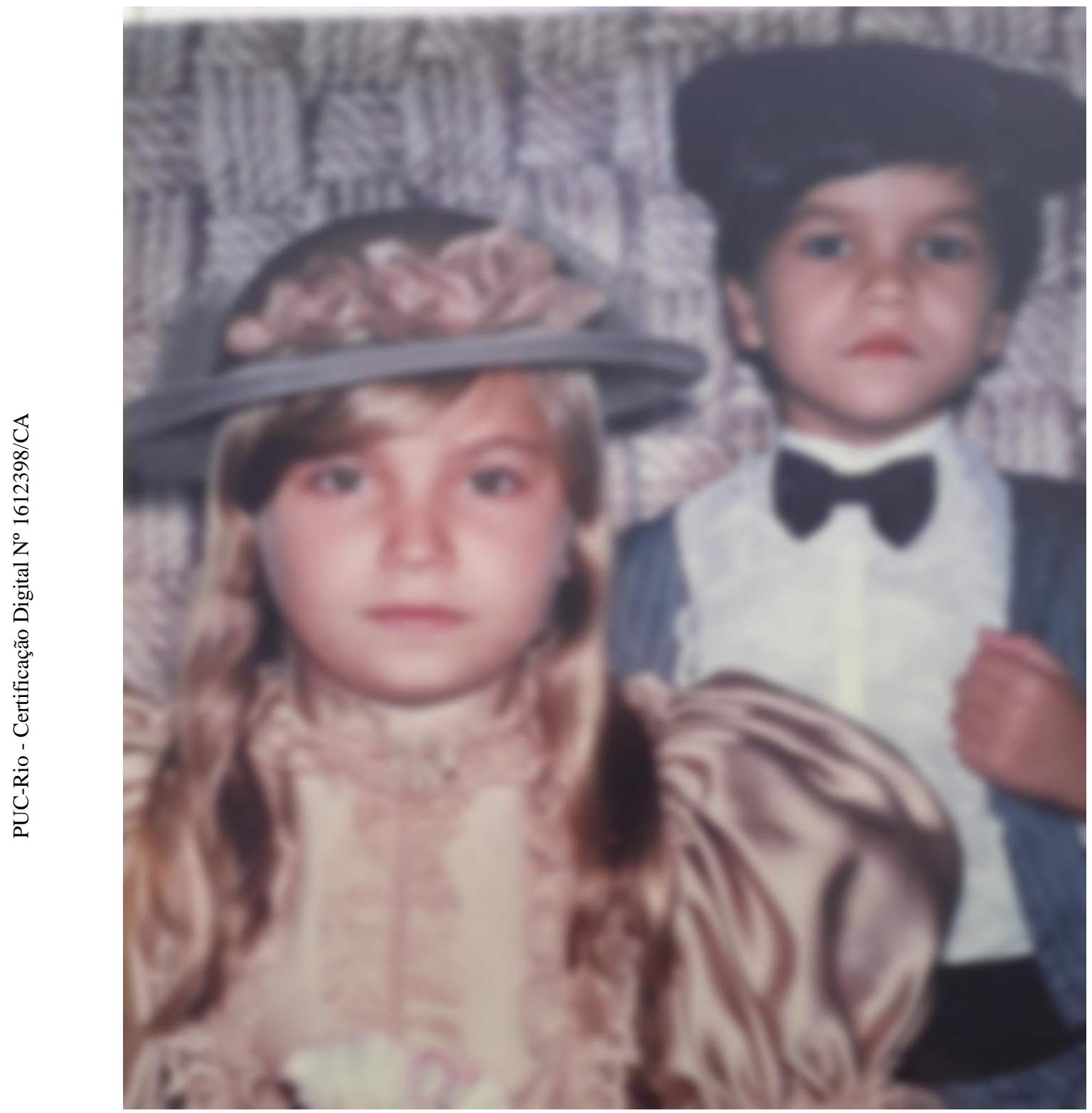

Figura 2. Arquivo pessoal foto escolar 2. 
Registros escolares de crianças brancas vestidas como os senhores e as senhoras coloniais escravocratas. Menina sentada, menino de pé, atrás, como uma espécie de autoridade masculina guardiã.

Analisando tais registros, pensei no que traziam de revelador sobre os mecanismos de socialização racistas, patriarcais e classistas na infância, que desde muito cedo nos ensinam a admirar essas lógicas e, consequentemente, desejar sua preservação. Este é um processo que se estende ao longo da vida e vai sendo atualizado ao longo da história. Um movimento que nos faz aceitar e reproduzir cotidianamente o racismo, o sexismo e o classismo e ao mesmo tempo negá-lo das mais diversas maneiras (relativizando, transformando em "humor", distorcendo os fatos).

Logo depois, lendo Kilomba (2019), me deparei com sua proposição de que a pergunta sobre se os brancos são racistas deve dar lugar aos questionamentos sobre como o racismo constitui os brancos e o que estes devem fazer para desconstruir esse modo de ser, estar e organizar o mundo, não apenas no âmbito individual, mas também coletivo. Revisitando minhas memórias de infância, compreendi sua proposição e busquei, através de outros diálogos e leituras, aprofundar esta compreensão.

Alguns dias depois de me deparar com essas fotografias e fazer algumas reflexões sobre elas, com a ajuda de Kilomba, fui indagada sobre minha branquitude por uma estudante que participava de uma discussão sobre racismo, organizada através de um projeto de rodas de debate quinzenais sobre diversos assuntos que eu desenvolvia com estudantes do Ensino Fundamental II de uma escola da rede municipal em que trabalhava. No final dessa roda, a estudante, de 15 anos, autodeclarada "morena" e homossexual - e considerada uma adolescente problemática pela instituição - perguntou se poderia me fazer uma pergunta. Eu respondi positivamente. Ela então foi à diante e disse:

É que você traz esses vídeos para nós, faz essas discussões com a gente, nos coloca para refletir criticamente sobre homofobia e racismo, por exemplo. Eu acho isso muito legal, até porque nunca vi esse tipo de coisa na escola, mas eu fico me perguntando: você é branca, tem estudo, é casada com um homem, tem um filho. Ou seja, você é tudo isso que você "critica" (ela pôs as aspas nesta palavra através de gestos com as mãos). Eu queria entender, por que você se importa com a gente? 
Uma sensação imediata de mal-estar me tomou e um turbilhão de pensamentos e sentimentos foi disparado em mim. A estudante questionava o lugar de "normalidade" que eu ocupo na ordem social instituída. Um lugar de alguns privilégios que para ela representava necessariamente, e não à toa, uma conduta opressora e desinteressada em relação ao seu grupo social, repetidamente visto como "desviante" aos olhos não só da instituição escolar, mas, mais amplamente, de toda a sociedade.

A indagação da estudante trazia as marcas traumáticas de diversas discriminações presentes em nossa sociedade, no entanto, em última instância, ela denunciava a violenta branquitude. Ainda que eu sustentasse em nossos encontros uma posição crítica a ordem racista, sexista e classista dominante e, em alguma medida, a estudante reconhecesse isso, seu questionamento revelava que eu pertencia a um grupo opressor e que o meu "lugar de fala" (RIBEIRO, 2017) era o da branquitude e, portanto, o da (re)produção do racismo. A subalterna falou e, na sua fala, ao colocar meu lugar em questão, o revelou: seu lugar é, originalmente, o lugar da violência contra mim e os meus.

Articulando a noção psicanalítica de repressão ao que Fanon (2008) chamou de "medo branco", Kilomba o define como o medo do/a colonizador/a de que a/o colonizado fale por si mesmo. Segundo a teoria psicanalítica freudiana, a repressão tem como essência o movimento de se afastar de algo que lhe causa incômodo, mantendo-o à distância do consciente. Trata-se, portanto, de uma “defesa pela qual o ego controla e exerce censura em relação ao que é instigado como uma verdade 'desagradável'" (KILOMBA, 2018, p. 42). O "medo branco" seria justamente o medo de entrar em contato com a verdade a ser revelada pelo sujeito negro. Uma revelação que tiraria do silêncio a responsabilidade do sujeito branco na violenta produção e prática do racismo.

Nessa dinâmica, Kilomba considera que, para o sujeito negro, falar tornase virtualmente impossível, pois quando ele fala, seu discurso "é frequentemente interpretado como uma versão dúbia da realidade, não imperativa o suficiente para ser dita nem tampouco ouvida" (idem). De acordo com a autora, essa impossibilidade revela o projeto análogo pelo qual o falar e o silenciar emergem: 
$\mathrm{O}$ ato de falar é como uma negociação entre quem fala e quem escuta, isto é, entre falantes e suas/seus interlocutoras/es (Castro Varela e Dhawan, 2003). Ouvir é, nesse sentido, o ato de autorização em direção à/ao falante. Alguém pode falar (somente) quando sua voz é ouvida. Nessa dialética, aquelas/es que são ouvidas/os são também aquelas/es que "pertencem". E aquelas/es que não são ouvidas/os se tornam aquelas/es que "não pertencem" (KILOMBA, 2019, pp. 4243).

Dialogando com a pensadora pós-colonial indiana Gayatri Spivak (1986), Kilomba problematiza a possibilidade de fala e escuta das/os subalternas/os. Spivak afirma em seu texto "Pode a subalterna falar?", de 1986, que não é possível a subalterna falar ou recuperar sua voz. Sua argumentação se constrói não pela referência do falar em si, mas pela dificuldade de fala desse contingente de pessoas dentro do regime repressivo do colonialismo racista e patriarcal. No entanto, para Kilomba, tal posicionamento é problemático se visto como uma afirmação absoluta sobre as relações coloniais, pois sustenta, por exemplo, "a ideia de que o sujeito negro não tem capacidade de questionar e combater discursos coloniais" (p. 48). A autora aponta que:

A ideia de que uma subalterna que não pode falar, como explica Patricia Hill Collins (2000), encontra primeiro a ideologia colonial que argumenta que os grupos subordinados se identificam de modo incondicional com os poderosos e não têm uma interpretação independente válida de sua própria opressão - e, portanto, não podem falar. Em segundo lugar, a ideia de uma subalterna silenciosa pode também implicar a alegação colonial de que grupos subalternos são menos humanos do que seus opressores e são, por isso, menos capazes de falar em seus próprios nomes. Ambas as afirmações veem os colonizados como incapazes de falar, e nossos discursos como insatisfatórios e inadequados e, nesse sentido, silenciosos. Elas também vão ao encontro da sugestão comum de que grupos oprimidos carecem de motivação para o ativismo político por conta de uma consciência falha ou insuficiente de sua própria subordinação. No entanto, grupos subalternos - colonizados - não têm sido nem vítimas passivas nem tampouco cúmplices voluntárias/os da dominação (KILOMBA, 2019, pp. 48-49).

Kilomba considera assim desnecessário escolher entre a posição de se poder falar ou não, mas compreende que há nos argumentos de Spivak um alerta as/os críticas/os pós-coloniais sobre uma desromantização dos sujeitos resistentes. Para Kilomba, Spivak leva a sério o desejo de intelectuais pós-coloniais em dar ênfase a opressão e viabilizar as perspectivas dos grupos oprimidos, mas tem como objetivo desafiar uma suposição simplista de que é possível recuperar o ponto de vista da subalterna. Para ela, "a própria ausência (no centro) da voz da/o colonizada/o pode ser lida como emblemática da dificuldade de recuperar tal voz, 
e como confirmação de que não há espaço onde colonizadas/os podem falar" (p. 49).

$\mathrm{Na}$ minha resposta à estudante, primeiramente agradeci a pergunta e, em seguida, dividi com ela minha sensação imediata de mal-estar. Naquele momento, no entanto, eu não conseguia ainda compreender profundamente de onde essa sensação vinha. Falei apenas que sentia tristeza por ela sentir que poderia não ter importância para mim ou para qualquer pessoa, mas que, ao mesmo tempo, compreendia seu sentimento e via sentido nele diante da desigual sociedade em que vivemos. Falei sobre a importância da sua pergunta e do quanto ela era reveladora sobre essa desigualdade. Depois falei sobre como a convivência com estudantes e as experiências com as instituições escolares e as relações nelas estabelecidas vinham me mobilizando a buscar entender mais criticamente os diferentes lugares de poder que ocupamos em uma sociedade como a nossa, estruturada pelo racismo, pelo sexismo e pela desigualdade socioeconômica. Falei também sobre como ainda tinha muito mais perguntas do que respostas sobre isso, mas que meu ponto de partida era o de que todas/os elas/eles eram sim muito importantes e que suas vozes, suas análises, seus pontos de vista, eram imprescindíveis para que transformações reais nessas estruturas ocorressem. Repeti, como havia colocado no nosso primeiro encontro, que naquele grupo a única exigência era a de que todos pudessem falar e ser ouvidos com atenção.

Mas a questão colocada pela estudante reverberou por muitos outros dias. Ainda ecoa. Como uma espécie de "interrogação-guia" da minha busca por identificar e desmistificar minhas zonas de conforto e o que elas (re)produzem.

Não ouvir o sujeito negro, colocá-lo a margem, falar por ele, tem sido historicamente a estratégia do sujeito branco para manter seus privilégios e não entrar em contato com a posição de violência que ocupa (por ele mesmo criada e mantida). A noção de privilégio é trazida pela psicóloga brasileira Maria Aparecida Silva Bento (2014) como essencial para discutir a discriminação racial. Para ela, não colocar em questão o lugar ocupado pelo branco na história do Brasil rendeu ao grupo racial branco não só benefícios concretos, como terras e outras riquezas, mas benefícios simbólicos. 
Como aponta a psicóloga brasileira Lia Vainer Schucman (2014), na estrutura racializada que funda nossa sociedade, o branco não é apenas favorecido, mas produtor ativo desta estrutura, através de mecanismos mais diretos de discriminação e também da produção de um discurso que dissemina a democracia racial e o branqueamento. Tais discursos são construídos de modo a assegurar aos/as brancos/as as posições mais altas na hierarquia social, sem que isso seja encarado como privilégio de raça - "a crença na democracia racial isenta a sociedade brasileira do preconceito e permite que o ideal liberal de igualdade de oportunidades seja apregoado como realidade" (SCHUCMAN, 2014, p. 14).

Para Bento, há na omissão e distorção do lugar do branco no cenário de desigualdades raciais, um intenso componente narcísico, de autopreservação, que vem acompanhado de um forte investimento no posicionamento deste grupo racial como grupo de referência de humanidade, pelo qual todos os "outros" grupos devem se pautar. Na tarefa de garantir a preservação de si, o narcisismo gera aversões ao que é estranho, como se ele "pusesse em questão o 'normal', o 'universal', exigindo que se modifique, quando se autopreservar remete exatamente à imutabilidade" (BENTO, 2014, p. 30).

Bento considera que uma boa forma de compreender a branquitude e o processo de branqueamento é entender a projeção do branco sobre o negro, que ela, assim como Kilomba, identifica como tendo raiz no medo e no silêncio sobre os privilégios que ela mantém. A autora acrescenta que esse processo compromete a capacidade de identificação com o próximo, o que está nas bases da produção de uma intolerância generalizada contra tudo o que seja identificado como "diferente".

Bento levanta a hipótese de que, há nas relações raciais hierarquizadas uma oposição e ao mesmo tempo uma similaridade ao que ocorre no amor narcísico. Isto porque, o amor narcísico está relacionado com a identificação, assim como o ódio narcísico com a desidentificação. Nesse processo, "nossos semelhantes" são o nosso objeto de amor narcísico, detentor de tudo aquilo que consideramos bom em nós. É, portanto, a partir do modelo de si mesmo, do seu ego, que a escolha de objeto narcísica se dá - "ama-se o que se é, ou o que se foi, ou o que se gostaria de ser, ou mesmo a pessoa que foi parte de si” (idem). Em 
contrapartida, nosso ódio narcísico volta-se ao outro, identificado como "diferente", aquele que detém tudo que rejeitamos por considerarmos ruim ou mal, em um profundo processo de negação.

Uma coletividade, em geral incitada pela sua elite, posiciona-se como vítima e justifica antecipadamente os atos de injustiça que não deixará de executar. Imputando aos acusados toda espécie de crimes e de vícios, ela se purifica de suas próprias intenções turvas e transfere para outrem o que não quer reconhecer em si própria” (BENTO, 2014, p. 35).

A partir da expressão "dessemelhança", utilizada pela escritora Toni Morrison (1992, apud KILOMBA, 2019) para descrever a branquitude, Kilomba (2019) a compreende, assim como essa autora, como uma identidade dependente, cuja existência está atrelada à exploração da/o "Outra/o". Trata-se de uma identidade relacional produzida através de um processo de diferenciação. Uma identidade que é construída por brancas/os que, ao se autodefinirem como referência, colocam os grupos não brancos na posição de "diferentes", transformando-os nas/os "Outras/os". Nessa dinâmica, a negritude assume a função de forma primária de Outridade - a personificação dos aspectos repressores do "eu" branco - pela qual é construída a branquitude, de modo que "a/o "Outra/o" não é "outra/o" per se; ela/ele torna-se através de um processo de absoluta negação" (p. 38).

O sujeito negro torna-se assim aquilo com o que o sujeito branco não quer estar relacionado. Um fato que se baseia "em processos nos quais partes cindidas da psique são projetadas para fora, criando o chamado "Outro", sempre como antagonista do "eu" (self)" (KILOMBA, 2019, p. 36). O sujeito branco se divide dentro de si mesmo, assumindo e vivenciando como "eu" apenas a parte do ego que ele considera "boa" e projetando para fora, na/o "Outra/o", a parte considerada "má". Essa/e "Outra/o", o sujeito negro, torna-se assim a tela da projeção dos aspectos desonrosos que o sujeito branco não quer reconhecer em si, por lhe causarem extrema ansiedade, culpa e vergonha.

Nesse cenário de mundo embranquecido, o sujeito negro é, portanto, encarnado de tudo aquilo que está identificado como "ruim" e "imoral", como a agressividade e a sexualidade. Negras e negros passam assim a coincidir com a ameaça, a violência, "o excitante e também o sujo, mas desejável” (KILOMBA, 2019, p. 37). Para Kilomba, tal percepção permite à branquitude olhar para si 
como "moralmente ideal, decente, civilizada e majestosamente generosa, em controle total e livre da inquietude que sua história causa" (idem).

Podemos perceber que esse processo de negação também está presente na relação patriarcal estabelecida entre homens e mulheres. Isso fica evidente, por exemplo, na "Caça às bruxas", ocorrida na Europa entre os séculos XV e XVII um marco histórico da imposição extremamente violenta pela ordem patriarcal de uma "Outridade" às mulheres europeias, que se estendeu, com a colonização, às mulheres das colônias, neste caso imbricada a negação racista. Nas mulheres foi projetado tudo aquilo que a ordem patriarcal designava como "imoral" e "anormal" em termos de desejo e potência sexual. Os homens europeus demonizaram o sexo feminino, justificando assim a colonização dos corpos das mulheres, da sua sexualidade e da sua capacidade reprodutiva.

Como apontou Federici (2017), houve um intercâmbio entre a ideologia da bruxaria e a ideologia racista colonial. Bruxas eram mulheres que haviam feito um pacto, sobretudo sexual, com o Diabo, que por sua vez era representado pela figura de um homem negro. Uma perspectiva que articula dois processos de negação, o de caráter sexual e o de caráter racial (desumanizador). Ao produzir feminilidade e negritude como irracionalidade e bestialidade, expurga-se tudo aquilo com que os sujeitos brancos homens não querem se identificar, legitimando assim, ao mesmo tempo, a subalternização das mulheres e da população tida como "de raça inferior". Mas é sobre as mulheres deste grupo que essa dupla negação incide entrelaçada, com toda sua intensidade, naturalizando formas de subalternização e exploração nos mais diversos níveis.

Essa análise é fundamental para que possamos compreender a posição de privilégio que, por exemplo, mulheres brancas, por mais subalternizadas que sejam pela ordem patriarcal, ocupam em relação às mulheres negras e não brancas, subalternizadas pela imbricação sexismo-racismo na ordem colonial. Isto quer dizer que, o fato de serem as mulheres brancas, o sexo "Outro", o segundo sexo (BEAUVOIR, 2009), o "sexo-objeto" e, portanto, oprimidas pelo "sexosujeito", masculino, não as exime de ocupar posição de agente de opressão no âmbito racial. Há um pacto racista firmado entre mulheres brancas e seus algozes, expresso através da branquitude, que precisa ser colocado em questão. 
Se o que nós, feministas, desejamos enquanto classe sexual oprimida é a emancipação de todas as mulheres, a branquitude precisa ser posta em pauta de maneira crítica em todos os espaços, inclusive dentro de nós mesmas, como já nos indicou hooks (2019). Não há emancipação das mulheres sem erradicação do racismo e, deste modo, não há feminismo sem luta antirracista. Dito de outro modo, ou o feminismo é antirracista ou não é feminismo.

No processo de análise crítica da branquitude, a Negação é o primeiro mecanismo de defesa do ego pelo qual, de acordo com Paul Gilroy, o sujeito branco passa. Como traz Kilomba (2019), Gilroy considera que, além da negação, o sujeito branco deve passar por mais outros quatro mecanismos de defesa do ego - Culpa, Vergonha, Reconhecimento e Reparação - até ser capaz de "ouvir" o sujeito negro e se tornar consciente de sua própria branquitude e de si própria/o como perpetradora/perpetrador do racismo.

Pensando esse mesmo processo, Janet Helms, como apresenta Bento (2014), descreve seis estágios da evolução de uma possível identidade branca não racista: contato, desintegração, reintegração, falsa independência, imersão/emersão e autonomia. Para Helms, um reposicionamento do sujeito branco em relação ao seu processo de subjetivação racista só é possível com a aceitação da "sua própria branquitude, e as implicações culturais, políticas, socioeconômicas de ser branca, definindo uma visão do eu como um ser racial" (BENTO, 2014, p. 43).

Ao examinar cada um dos mecanismos identificados por Gilroy, Kilomba nos oferece uma análise fundamental. A articulação desta análise com aquela realizada por Helms aponta para pistas preciosas no que diz respeito às possibilidades e responsabilidades que devemos, nós brancas/os, assumir no combate e desmantelamento desse sistema de opressão criado pela própria branquitude: o racismo.

De acordo com Kilomba, a Negação (denial, em inglês, no sentido de recusa), primeiro mecanismo de defesa do ego na sequência apontada por Gilroy, opera, como já apresentado anteriormente, de forma inconsciente com objetivo de "resolver conflitos emocionais através da recusa em admitir os aspectos desagradáveis da realidade externa, bem como pensamentos e sentimentos 
internos" (p. 43). Este mecanismo, por sua vez, é seguido por dois outros: cisão e projeção. Isto é, o sujeito nega um sentimento/pensamento/experiência ao mesmo tempo que o projeta na/o "outra/o".

Podemos identificar a negação no primeiro estágio descrito por Helms. De acordo com ela, o estágio do contato, em geral, inclui uma curiosidade primitiva ou um medo das pessoas negras. Esse comportamento se produz com base em estereótipos fundados pela negação branca, que projeta tudo o que é considerado ruim no sujeito negro, e que são aprendidos desde cedo no processo de socialização em uma cultura racista como a nossa. Construções que restringem a própria consciência das questões raciais e a interação com pessoas negras.

Na sequência de Gilroy, a negação é seguida da Culpa. A culpa funciona como uma pancada emocional, em que o indivíduo fica consciente de ter feito algo que não deveria ter feito ou de ter deixado de fazer algo que deveria ter feito. Como aponta Kilomba, esse estado é descrito por Freud como resultado de um conflito entre ego e superego, isto é, "um conflito entre os próprios desejos agressivos do indivíduo em relação aos "outras/os" e seu superego (autoridade)" (p. 44). Diferentemente da negação, há nesse caso uma preocupação com as consequências do seu erro, no sentido de ser acusado, culpabilizado, punido.

Como resposta à culpa, frequentemente os sujeitos brancos lançam mão da intelectualização ou racionalização, na tentativa de construir uma justificativa lógica para o racismo. Como aponta Kilomba, podem ainda responder com a descrença, assumindo discursos de que foram mal interpretados em suas colocações, de que houve um mal-entendido.

Já a Vergonha, Kilomba descreve como o medo do ridículo, "a resposta ao fracasso de viver de acordo com o ideal de seu próprio ego" (p. 45). Se a culpa se instala a partir da transgressão de uma interdição exterior, a vergonha se dá ao falhar com o próprio ideal de comportamento estabelecido por si mesma/o. É quando o sujeito branco toma consciência de que "a percepção das pessoas negras sobre a branquitude pode ser diferente de sua percepção de si mesmo, na medida em que a branquitude é vista como uma identidade privilegiada - o que significa tanto poder quanto alerta - a vergonha é resultado desse conflito" (idem).

Seguido da vergonha está o Reconhecimento. Esse momento é descrito por Kilomba como aquele em que brancas/os, reconhecemos nossa própria 
branquitude. "O indivíduo reconhece a realidade de seu racismo ao aceitar a percepção e a realidade de "Outras/os"' (pp. 45-46). É quando acontece a passagem da fantasia para a realidade. Não se trata mais de como se gostaria de ser vista/o, mas como se é. E também não se trata mais de como se gostaria que as/os "outras/os" fossem, mas como elas/es de fato são.

Para Helms, a culpa, a vergonha e o reconhecimento, assim como a raiva, aparecem no estágio de desintegração. Eles ocorrem diante da "identificação de suas próprias vantagens por serem brancos e o reconhecimento do papel de indivíduos brancos na manutenção do sistema racista" (BENTO, 2014, p. 43).

Nesse estágio, para diminuir o desconforto é possível que as pessoas se convençam ou de que o racismo nunca existiu ou de que é culpa das vítimas. Há, neste caso, uma presença muito forte da crença dissimulada ou explícita na superioridade branca e o desejo de ser aceito pelo seu próprio grupo racial, que fazem com a pessoa busque uma readequação do seu sistema de crenças para tornar-se mais coerente com a aceitação do racismo, entrando no estágio de reintegração. A culpa e a vergonha produzidas no estágio de desintegração podem voltar-se na forma de medo e raiva contra negros, identificados agora como fonte de mal-estar emocional.

De acordo com Helms, é fácil que brancas/os paralisem no estágio de reintegração, em especial se evitam maiores contatos com pessoas negras. No entanto, ela considera que, se existe um catalisador para continuar a autorreflexão, a pessoa coloca em questão sua condição de ser branca e a justificação do racismo. É quando ela vai experimentar um senso de alienação em relação aos membros do seu grupo racial que não questionam seu próprio racismo.

Essa posição desconfortável com a branquitude pode fazer o sujeito buscar uma nova maneira de ser branco. De acordo com Helms, essa busca acontece no estágio de imersão/emersão, quando a pessoa busca informações, leituras críticas sobre a branquitude, referências antirracistas, que possibilitem construir outros modos de ser branca/o, comprometidos com o combate ao racismo.

O desenvolvimento dessa imersão/emersão levará ao estágio de autonomia, que tem como tarefa básica a internalização de uma nova percepção do que é ser branco. Como aponta Bento, são os sentimentos positivos associados a esta redefinição que energizam os esforços pessoais para combater a opressão e o racismo na sua vida cotidiana, "um processo sempre em andamento, no qual a 
pessoa precisa estar continuamente aberta a novas informações e novas formas de pensar sobre variáveis culturais e raciais" (BENTO, 2014, p 44).

O último mecanismo da lista de Gilroy é a Reparação, que Kilomba apresenta como a negociação do reconhecimento. É, portanto, quando negociamos com a realidade. Como afirma a autora, "esse último estado é o ato de reparar o mal causado pelo racismo através da mudança das estruturas, agendas, espaços, posições, dinâmicas, relações subjetivas, vocabulário, ou seja, através do abandono dos privilégios" (p. 46). E podemos entendê-lo como inserido no estágio de autonomia, definido por Helms. Isto é, a reparação se dá a partir do momento em que sustentamos permanentemente uma nova percepção e posição de ser brancas/os, que não só não pactua com o racismo, como se compromete de fato com a luta por sua abolição.

Para desmantelar o racismo é preciso, portanto, que brancas/os assumamos a responsabilidade sobre ele. Como afirma Fanon (2008), é preciso admitir que o racismo é uma invenção branca que visa a criação e manutenção de privilégios materiais e simbólicos deste grupo racial.

A partir disso, é preciso colocar em questão e buscar desarticular mecanismos de autoproteção e autopreservação pautados na exclusão de vozes, espaços e existências dos segmentos racialmente subalternizados. Trata-se de uma desconstrução contínua, que exige redimensionamentos e reposicionamentos constantes. Sustentar desconfortos, compreendendo que o "conforto" buscado se constitui a partir da violência historicamente direcionada pelo grupo racial branco a pessoas e grupos que foram identificados como "outros". Esse movimentonão pode se restringir a esfera íntima. Trata-se de um reposicionamento pessoal/político comprometido com a luta antirracista, que abrange, portanto, todas as nossas práticas coletivas (familiares, profissionais, comunitárias, institucionais).

Esse processo não é simples, mas urgente, fundamental e cotidiano. Do contrário, os/as brancos/as, seguiremos compactuando e reproduzindo (produzindo atualizações), lógicas perversas que fazem, por exemplo, crianças e adolescentes, como exposto na fala da estudante do nosso grupo de debate, crescerem sentindo que não tem importância. 


\section{CAPÍTULO 4. EDUCAÇÃO, COLONIALIDADE E ABANDONO}

\subsection{Fundamentos da escola pública no Brasil e Colonialidade: caminhos para o fracasso}

De maneira geral, estudantes não abandonam a escola de uma hora pra outra. O abandono vai sendo anunciado por uma série de movimentos: falta de interesse nas aulas, faltas excessivas, baixa no rendimento escolar e, em alguns casos, conflitos com a instituição e seus membros. Existe um fracasso escolar que vai sendo anunciado. Mas quem fracassa?

É comum receber dos membros das equipes escolares que buscam o serviço de Psicologia Escolar a queixa de que estudantes fracassam na vida escolar por "não quererem nada", "serem preguiçosos" ou terem alguma deficiência cognitiva e/ou psíquica. Mas não são raros os casos de estudantes que enfrentam uma longa e cansativa jornada até chegarem à escola, sendo difícil que de fato sejam indolentes. Assim como, com frequência, aquela/e estudante a que se atribuem transtornos de aprendizagem, apresenta diversas habilidades fora da sala de aula. Então por que eles estão desinteressados? Ou a pergunta a ser feita não deveria ser: o que vem sendo oferecido a essa juventude pela sociedade e, mais especificamente, pela escola, para que "nada queiram"?

Segundo Baremblitt (2002), uma sociedade é um tecido de instituições que se interpenetram e se articulam entre si para regular a produção e a reprodução da vida humana no mundo e a relação entre os seres humanos. Lourau (1993) afirma que as instituições não são coisas observáveis, estáveis, e sim dinâmicas contraditórias, movimentos forjados na história, no tempo social-histórico. Não tem concretude, mas são lógicas que regulam as atividades humanas, estabelecendo o que deve e o que não deve ser feito. Elas podem estar anunciadas de maneira formal, na forma de leis e normas ou se manifestar através de hábitos, convenções sociais e regularidades de comportamento.

Para a Análise Institucional, ao conjunto de forças que atuam nas instituições para produzir permanência do que está posto denomina-se "instituído" (LOURAU, 1993; BAREMBLITT, 2002). O instituído representa o status quo, 
aquilo que se encontra estabelecido e até naturalizado. Foucault (2001) aponta que o instituído se constitui a partir de jogos de verdades sempre articulados a estratégias de saber-poder, que fixam determinadas regras pensadas como incontestáveis, separando o legítimo do ilegítimo, o normal do anormal, o certo do errado, etc.

É sendo materializadas em dispositivos concretos, em "organizações" (BAREMBLITT, 2002), que as instituições (de dimensão abstrata) cumprem a função de regular a vida. As organizações são conjuntos de formas materiais que concretizam as opções enunciadas pelas instituições, sendo constituídas por unidades menores, como os estabelecimentos, isto é, locais onde os agentes humanos protagonizam a prática, operando dispositivos técnicos de reprodução da lógica institucional.

Nessa perspectiva, a escola é um estabelecimento e tem uma base concreta, como o prédio e os equipamentos. Agenciado por gestoras/es, professoras/es, funcionárias/os e suas técnicas, esse estabelecimento funciona de modo a reproduzir a lógica das instituições de educação - leis, normas e pautas que prescrevem como se deve socializar e instruir um indivíduo para que este possa integrar a sociedade.

Foucault (2009) aponta que, no decorrer dos séculos XVIII e XIX, as disciplinas assumem o caráter de fórmulas gerais de dominação, dando origem às sociedades disciplinares. Sob a justificativa de segurança, dispositivos disciplinares são acionados, operando uma constante divisão entre o que é normal e o que é anormal, a qual todo indivíduo é submetido. São dispositivos que vão se constituir a partir da composição de técnicas de controle e correção dos considerados anormais, desenvolvidas no interior de "instituições de sequestro" (FOUCAULT, 2009), como escola, fábrica, prisão, hospital, etc. Instituições que operam técnicas para extrair a totalidade do tempo dos indivíduos e controlar seus corpos, transformando o corpo em força de trabalho e o tempo em tempo de trabalho.

Essas mudanças respondem aos desdobramentos das profundas transformações econômicas, políticas e sociais vividas nesse período. Com a Revolução Industrial, iniciada em meados do século XVIII, o processo de urbanização se intensifica. Há um grande deslocamento de populações rurais para os centros urbanos e surge uma nova forma de acumulação de riqueza, que passa a 
ocorrer em forma de estoque, máquinas e mercadoria armazenada, tornando necessária a vigilância.

De acordo com Veiga-Neto e Saraiva (2011), a escola moderna funcionou como principal dispositivo para disciplinar os corpos, possibilitando assim a consolidação do capitalismo industrial. Tornou-se, afirmam, "a mais generalizada instituição de sequestro, sendo sua ação muito mais decisiva para a constituição das sociedades disciplinares do que outras instituições" (VEIGA-NETO \& SARAIVA, 2011, p. 6).

É partindo da noção de governamentalidade, trazida por Foucault (2008), que Veiga-Neto e Saraiva compreendem porque os Estados modernos tomaram a educação escolar como uma instituição privilegiada, concedendo atenção especial ao estabelecimento de seus objetivos e formas de funcionamento. Foucault (2008) define a governamentalidade como um conjunto de práticas de governamento que tem como objeto a população, como saber mais importante a economia e como mecanismos básicos dispositivos de segurança (FOUCAULT, 2008).

De acordo com Veiga-Neto e Saraiva (2011), a educação escolar, afinada com a racionalidade política moderna, ao mesmo tempo totaliza e individualiza os sujeitos. Isto porque, "se por um lado a escola constitui individualidades singulares, criando subjetividades que se pensam únicas e indivisíveis, ela também cria posições de sujeito subordinadas a um todo social, fora das quais cada sujeito nem mesmo faz sentido" (VEIGA-NETO \& SARAIVA, 2011, p. 9). Este movimento impede que o indivíduo seja pensado ou que pense a si mesmo como um sujeito - sujeito de e assujeitado a.

Nesse sentido, a visão da educação escolar como essencialmente agregadora e fomentadora de pensamento crítico pode ser colocada em questão. Ela surge na modernidade tendo como fundamento a desagregação - a cesura entre o normal e o anormal, o apto e o não apto. A governamentalidade moderna cria a escola - um estabelecimento educacional cuja arquitetura, gestão e técnicas pedagógicas e educacionais adotadas têm como objetivo primeiro a disciplinarização e normatização dos corpos das/os estudantes.

Afirmar que o que está instituído sobre a educação escolar foi construído a partir da matriz político-social e epistemológica da modernidade é dizer que sua função de governar os corpos se estrutura na colonialidade, isto é, no racismo, no 
sexismo e classismo imbricadamente. Como visto anteriormente, e como reforçam Candau e Oliveira (2010), a modernidade não pode ser entendida sem se levar em conta a herança colonial e as diferenciações que o poder moderno/colonial instituiu para produzir subalternização e assim legitimar a exploração de grupos humanos.

No contexto latino-americano, como afirma Candau (2011), o processo de homogeneização cultural que precedeu a construção dos estados nacionais teve a educação como uma das principais vias de difusão e consolidação da cultura comum, de base eurocêntrica. Através da adoção de estratégias pedagógicas que contribuíram para o silenciamento e/ou invisibilização de vozes, saberes, cores, crenças e sensibilidades, institui-se um modelo educacional que não considera os múltiplos modos de existência, desqualifica as experiências coletivas e cria normas fixas e totalizantes.

Nesse processo, podemos dizer que nos países que sofreram a colonização, a disciplinarização e normatização objetivada e promovida pelas instituições escolares - de que nos falam Foucault, Veiga-Neto e Saraiva - partem de um modelo de normalidade que tem a Europa como referência. Assim, um indivíduo "educado" e "inteligente" passa a ser entendido como aquele capaz de introjetar e performar ao máximo o modelo eurocentrado de sujeito do conhecimento, ou seja, de certo modo de ser, ver e operar no mundo. Em contrapartida, sobre aqueles que não conseguem alcançar tal modelo e, mais ainda, sobre aqueles que o rejeitam, opera-se uma imposição educacional normativa violenta, baseada em controle, vigilância, punição e exclusão.

No Brasil, é na grande propriedade e na mão de obra escrava que a economia colonial se funda, tendo implicações profundas de ordem social e política. Como aponta Romanelli (2014), ela favorece o surgimento "da unidade básica do sistema de produção, de vida social e do sistema de poder representado pela família patriarcal" (p. 33). O isolamento e a estratificação sociais, aliados à necessidade de manter uma organização de segurança, favoreceram uma estrutura de poder fundada na autoridade irrestrita do dono das terras e que importou as formas de pensamento e modos de vida dominantes europeus. Como aponta Romanelli, o branco colonizador desejava se distinguir da população nativa, negra e mestiça, existente e uma das formas disso acontecer era garantir que a classe 
dominante, detentora do poder político e econômico, fosse também detentora dos bens culturais importados.

Dessa maneira, as condições objetivas que favoreceram a ação educativa foram a organização social e o conteúdo cultural transportado da metrópole para a Colônia, através dos jesuítas. No âmbito da organização social, consistia na predominância de uma minoria de donos de terra e senhores de engenho e uma maioria de agregados e escravizados. Como aponta Romanelli, o direito à educação escolar era restrito apenas aos primeiros e, mesmo assim, em número restrito, visto que não incluía as mulheres e os filhos primogênitos - aos quais era reservado a direção futura dos negócios do pai e, portanto, apenas uma preparação para assumir essa posição, que incluía também a direção da família.

Em relação a segunda condição, o conteúdo cultural, este se encontrava sobre o domínio dos padres e era, primeiramente, a materialização do próprio espírito da Contrarreforma, isto é, da reação contra o pensamento crítico que despontava na Europa. Desprezando a ciência, em nome do apego a formas dogmáticas de pensamento, os jesuítas voltavam-se ao ensino das letras, que tornava-se sua maior preocupação.

Humanistas por excelência e os maiores de seu tempo, concentravam seu esforço, do ponto de vista intelectual, em desenvolver nos seus discípulos as atividades literárias e acadêmicas, que correspondiam, de resto, aos ideais de "homem culto" em Portugal, onde, como em toda a Península Ibérica, se encastelara o espírito da Idade Média e a educação, dominada pelo clero, não visava por essa época se não a formação de letrados eruditos. $\mathrm{O}$ apego ao dogma e à autoridade, a tradição escolástica e literária, o desinteresse quase total pela ciência e a repugnância pelas atividades técnicas e artísticas tinham forçosamente de caracterizar, na Colônia, toda a educação modelada pela metrópole, que se manteve fechada e irredutível ao espírito crítico e de análise, à pesquisa e à experimentação (AZEVEDO, 1953, p. 228 apud ROMANELLI, 2014, p. 34).

Não podemos perder de vista que a ação jesuítica no Novo Mundo tinha como objetivos o recrutamento de fiéis e servidores, ambos a serem atingidos através da ação educadora. Como aponta Romanelli, a catequese propiciou "a conversão da população indígena e foi levada a cabo mediante criação de escolas elementares para os 'curumins' e de núcleos missionários no interior nas nações indígenas" (p. 35).

Esta educação era estendida aos filhos homens dos colonos, garantindo sua evangelização. Mas foi principalmente para os servidores da Ordem, homens da camada dominante que eram em sua maioria preparados para o exercício do 
sacerdócio, que se fundaram os colégios, onde se ensinavam as ciências humanas, as letras e as ciências teológicas. Gradativamente, a obra da catequese - que a princípio foi o objetivo principal da Companhia de Jesus - foi dando lugar à educação da elite e assim se firmando, não só durante o período em que permaneceu por essas terras, como ainda após a expulsão dos jesuítas, no século XVIII.

De acordo com Romanelli, a educação dada pelos jesuítas foi transformada em educação de classe, guardando características que bem distinguiam a aristocracia rural brasileira,

que atravessou todo o período colonial e imperial e atingiu o período republicano, sem ter sofrido, em suas bases, qualquer modificação estrutural, mesmo quando a demanda social de educação começou a aumentar, atingindo as camadas mais baixas da população e obrigando a sociedade a ampliar sua oferta escolar. Era natural que assim fosse, porque esse tipo de educação veio a transformar-se no símbolo da própria classe, distintivo desta, fim, portanto, almejado por todo aquele que procurava adquirir status [...] Símbolo de classe, esse tipo de educação livresca, acadêmica e aristocrática foi fator coadjuvante na construção das estruturas de poder na Colônia. Isso porque a classe dirigente, aos poucos, foi tomando consciência do poder dessa educação na formação de seus representantes políticos junto ao poder público. Os primeiros representantes da Colônia junto as cortes foram filhos dos senhores de engenho educados no sistema jesuítico. Casaram-se, assim, portanto, a grande propriedade, o mandonismo e a cultura transplantada expandida pela ação pedagógica dos jesuítas (ROMANELLI, 2014, p. 36).

Rizzini e Rizzini (2004) apontam que desde o período colonial, colégios internos, seminários, asilos, escolas de aprendizes, educandários, dentre outras modalidades institucionais foram sendo criadas a partir das tendências educacionais e assistenciais de cada época. Tais iniciativas educacionais estavam entrelaçadas aos objetivos de assistência e controle social da população das camadas mais pobres que, no crescimento e reordenamento das cidades e a constituição de um Estado nacional, era representada cada vez mais como perigosa.

De acordo com Rizzini e Rizzini, a partir da segunda metade do século XIX, a categoria jurídica dos menores de idade provenientes das classes pobres assume um caráter eminentemente social e político, o chamado "sistema tutelar menorista" (ARANTES, 2009). Eles passam a ser "alvo específico da intervenção formadora/reformadora do Estado e de outros setores da sociedade, como as 
instituições religiosas e filantrópicas" (RIZZINI \& RIZZINI, 2004, p. 22). As autoras apontam que:

O recolhimento de crianças às instituições de reclusão foi o principal instrumento de assistência à infância no país. Após a segunda metade do século XX, o modelo de internato cai em desuso para os filhos dos ricos, a ponto de praticamente ser inexistente no Brasil há vários anos. Essa modalidade de educação, na qual o indivíduo é gerido no tempo e no espaço pelas normas institucionais, sob relações de poder totalmente desiguais, é mantida para os pobres até a atualidade. A reclusão, na sua modalidade mais perversa e autoritária, continua vigente até hoje para as categorias consideradas ameaçadoras à sociedade, como os autores de infrações penais. O país adquiriu uma tradição de institucionalização de crianças, com altos e baixos, mantida, revista e revigorada por uma cultura que valoriza a educação da criança por terceiros - cultura que permeia amplos setores da sociedade, desde os planejadores até os grupos sociais de onde saem os internos. As instituições atendiam a grupos diversificados, de acordo com as prescrições de gênero, mas consideravam ainda as especificidades étnicas. Meninos e meninas índios ou filhos de escravas e libertas passaram por asilos, casas de educandos, institutos e colégios (RIZZINI \& RIZZINI, 2004, p. 22).

Frigotto (2005) afirma que, no Brasil, mesmo com a constituição do regime republicano, as práticas políticas das elites coloniais, que reiteram formas de subalternidade não foram apagadas. Segundo ele, dominam até a década de 1930 as forças da república velha, centrada em oligarquias agrárias, entre as quais a educação escolar era um privilégio de poucos. Desta maneira, as classes subalternizadas seguiram relegadas ao analfabetismo ou, em alguns casos, ao ensino primário.

Em 1920, no plano contraditório das lutas da burguesia industrial emergente e da burguesia agrária, a diminuição do analfabetismo começa a interessar à indústria, abrindo espaço para o acesso à escola pública. É a partir dessa abertura que, em meados do século XX, constituem-se os chamados "sistemas nacionais de ensino", que tem sua organização inspirada no princípio de que a educação é direito de todos e dever do Estado.

Para a nova ordem que se instala, o marginalizado é aquele que não teve acesso aos saberes desejáveis em um contexto escolar formal. Nesta perspectiva, a escola é eleita como o instrumento para transformar todas/os em cidadãos, "redimindo os homens de seu duplo pecado histórico: a ignorância, miséria moral e a opressão, miséria política" (ZANOTTI, 1972 como citado em SAVIANI, 1999, p. 18). A educação, vista como um instrumento de equalização social e, portanto, de superação da marginalidade, assume assim uma função coercitiva. Uma força homogeneizadora, cujo papel é o de coesão, garantindo a integração de 
todos no corpo social. Para Ferreiro, a escola pública, gratuita e obrigatória do século XX, é herdeira desse movimento, cabendo a ela

[...] criar um único povo, uma única nação, anulando as diferenças entre os cidadãos, considerados como iguais diante da lei. Se os cidadãos eram iguais diante da lei, a escola devia contribuir para gerar estes cidadãos, homogeneizando as crianças, independentemente de suas diferentes origens (FERREIRO, 2001 apud CANDAU, 2011, p. 242).

Os estudos de Paulo Freire $(1987,1979)$ no campo da educação, nos permitem compreender que as elites das sociedades que se constituíram a partir de um processo de colonização reproduzem a lógica colonizadora, pois é esta que garante a manutenção de seus privilégios. Neste sentido, pode-se considerar que a criação de estabelecimentos de educação pública, gratuita e obrigatória, se dá fundamentalmente a partir da necessidade de dominar e ocupar indivíduos oriundos das camadas mais pobres, consideradas um risco moral para o projeto de nação que a elite branca desenvolvia no final do século XIX, com o objetivo de manter seus privilégios (NASCIMENTO, 2005; COIMBRA, 2000).

É importante considerar, ao longo da história, contrapoderes e resistências. Podemos observar algumas modulações progressistas nas políticas, práticas e discursos educacionais e pedagógicos - fruto de significativos movimentos populares, de educadoras/es e estudantes. Como afirma a pedagoga e primeira mulher negra a tornar-se reitora de uma universidade pública federal no Brasil, Nilma Lino Gomes (2017):

A educação não é um campo fixo e nem somente conservadora. Ao longo dos tempos é possível observar como o campo educacional se configura como um espaço-tempo inquieto, que é ao mesmo tempo indagador e indagado pelos coletivos sociais diversos. Enquanto espaço de formação humana e pelo qual passam as mais diferentes gerações, grupos étnicos-raciais, pessoas de origens socioeconômicas diferentes, credos e religiões, é possível refletir tanto os processos institucionais de educação (escola de educação básica e universidades) quanto experiências de educação popular, social, de jovens e adultos, diferenciada e antirracista, construídas no cotidiano e nos processos de luta sociais, são repletos, ao mesmo tempo, de um dinamismo incrível e de uma tensão conservadora (p. 25).

Um dos exemplos recentes disso é promulgação da Lei $N^{\circ} 10.639 / 2003$, que proporcionou a introdução formal da discussão étnico-racial nas escolas. Essa lei é fruto de discussões e ações do movimento negro que já vinham acontecendo e ganharam força a partir da década de oitenta - período em que ocorreram mudanças significativas na perspectiva de lutas contra o racismo, tendo como uma 
das principais estratégias a construção de ações afirmativas para a população negra (PEREIRA, 2016). A instituição das cotas raciais também é proveniente desse movimento.

No entanto, sabemos que a mentalidade colonial fundante das instituições de ensino persiste e opera constantes capturas em todo e qualquer movimento que busque produzir rupturas com os sistemas de dominação. Via de regra, no cotidiano da escola, vemos, por exemplo, uma constante neutralização das discussões e ações propostas pelas políticas afirmativas. Muitas vezes são as/os professoras/es que politicamente sustentam sozinhas/os essas discussões e práticas em suas salas de aula, sem apoio e até sob ameaças das equipes diretivas e secretarias de educação. Ao que parece, aos olhos da instituição, esse tipo de discussão só pode ocorrer como folclore, alegoria, "tema" e jamais em uma perspectiva crítica capaz de produzir transformações, rupturas e emancipação.

Walsh (2009) aponta que, se foi a partir de padrões de poder fundados na exclusão, negação e subordinação que a modernidade/colonialidade funcionou historicamente, na contemporaneidade ela se dá sob um discurso neoliberal multiculturalista. No contexto escolar, tal discurso pode ser entendido como um modo de captura operado pela persistente lógica colonial, que atravessa e constitui os sistemas educacionais ainda hoje.

Candau (2008) traz três perspectivas consideradas por ela como bases das diversas abordagens sobre o tema do multiculturalismo. A primeira delas é o multiculturalismo assimilacionista, que afirma que vivemos em uma sociedade multicultural no sentido descritivo. Admite a existência de desigualdade de oportunidades, havendo grupos culturais, étnicos e/ou de classes para os quais o acesso a certos serviços, bens, direitos fundamentais são precários em relação aos grupos sociais de classe média ou alta, brancos e escolarizados. A partir disso, adota uma política assimilacionista, que favorece todos a se integrarem na sociedade, sendo incorporados à cultura hegemônica. Uma política de universalização da escolarização é promovida, mas o caráter monocultural presente na sua dinâmica não é questionado, seja no que se refere ao currículo, seja no âmbito das relações entre os diferentes atores - como as estratégias metodológicas e os valores a serem privilegiados. Persiste assim a defesa do projeto de construir uma cultura comum, deslegitimando os saberes, línguas, 
dialetos, crenças dos grupos subalternizados, considerados inferiores explícita ou implicitamente.

A segunda abordagem é a do multiculturalismo diferencialista. Nela enfatiza-se o reconhecimento da diferença, garantindo espaços em que estas possam se expressar como única maneira dos diferentes grupos socioculturais manterem suas matrizes culturais de base. De acordo com Candau, "algumas das posições nessa linha terminam por ter uma visão estática e essencialista da formação das identidades culturais" (2008, p. 51). O acesso a direitos sociais e econômicos é posto em pauta, mas, ao mesmo tempo, privilegia-se a formação de comunidades culturais homogêneas que tenham suas próprias organizações (escolas, igrejas, clubes, associações, bairros). Na visão da autora, em muitas sociedades atuais, na prática, "terminou-se por favorecer a criação de verdadeiros apartheids socioculturais" (idem).

O multiculturalismo interativo ou interculturalidade é definida por Candau (2008) como multiculturalismo crítico e de resistência, que se situa a partir de uma agenda política de transformação. Esta abordagem compreende as representações étnicas, sexuais e de classe como produto das lutas sociais sobre signos e significações, privilegiando a transformação das relações sociais, culturais e institucionais em que os significados são gerados. Concebe as culturas como movimentos contínuos de construção e reconstrução, cujas raízes são históricas e dinâmicas, não estanques.

Nessa perspectiva, a cultura assume um caráter conflitivo, onde a diferença deve ser afirmada dentro de uma política crítica e compromissada com a justiça social. Há uma desromantização das relações culturais que, concebidas como construções históricas, são atravessadas por relações de poder hierarquizadas, marcadas pelo preconceito e pela discriminação de determinados grupos. Vinculando as questões das desigualdades em conflito, no plano mundial e em cada sociedade, afirma-se essa relação, que é complexa e admite diferentes configurações em cada realidade.

No contexto escolar que conhecemos, a primeira forma de praticar o multiculturalismo, apresentada por Candau, é predominante, seguida, em menor escala, da segunda. Quando ouvimos atentos as queixas das/os estudantes, percebemos que esta predominância constitui uma linha de força importante na produção de desânimo em relação a escola, assim como de exclusão. 
Uma queixa frequente é sobre os conteúdos - sobre por que e para que aprendê-los. Essa falta de sentido é frequentemente apontada como razão do não interesse nas aulas e denuncia, em grande medida, o abismo existente entre esses conteúdos e as experiências vividas pelas/os estudante nos seus diversos contextos.

Outra queixa comum é sobre o formato da escola. "Chatice", "inferno", "porcaria", [vontade de] "quebrar tudo", “obrigação", "preguiça", são termos utilizados pelas/os estudantes quando indagadas/os em grupo sobre o que a escola representa para elas/es. Quando aprofundada a discussão, explicam que entendem que a função da escola é ensinar, mas identificam a sala de aula como o lugar da "mesmice", monotonia e passividade. Parece que não se sentem ativos no processo de aprendizagem e sinalizam insatisfação com a objetificação que esse espaço lhes impõe.

A permanência da hierarquização cultural - onde a cultura eurocêntrica predomina - nos conteúdos e nas metodologias escolares tem um papel fundamental na manutenção da colonialidade. $O$ discurso multicultural assimilacionista, ainda que em teoria defenda a promoção de igualdade no acesso aos direitos, ao apontar a assimilação da cultura hegemônica como o caminho para alcançar tal igualdade, não só não coloca em questão a hierarquia cultural, a violência e produção de desigualdades intrínsecas a ela, como a reforça e atualiza para continuar operando de modo mais "sutil", porém não menos violento.

Nesse processo, em termos teóricos, continua-se a reproduzir a história pautada no registro dos "vencedores", dos grupos dominantes (BENJAMIN, 2002), repetindo e legitimando assim uma série de estereótipos criados pelo discurso e prática coloniais. Em termos práticos, perpetuam-se abordagens pedagógicas e educacionais que desqualificam, descartam e/ou patologizam modos de viver, de sentir, de se relacionar, de produzir conhecimento, de aprender etc.

A multiplicidade é tratada como sinônimo de diferença (em relação a um modelo referente, "normal") e, desta maneira, como adversidades a serem superadas. Um olhar que reafirma a colonialidade do sistema, tendo efeitos importantes nas formações subjetivas e traçando, assim, caminhos para o fracasso. 


\subsection{Desigualdade Racial, Psicologia escolar e individualização do fracasso}

Como dito anteriormente, ao longo da minha prática profissional em escolas venho observando que os sinais de "fracasso" que apontam para um futuro abandono, em geral, quando não são invisibilizados, são tratados como problemas individuais, pelos quais a equipe escolar afirma ter pouco a fazer. Partindo desta visão é que alguns/as estudantes são encaminhados/as ao serviço de psicologia escolar, com a demanda de avaliação e encaminhamento para tratamento psicológico fora da escola, numa perspectiva individualizante, muitas vezes com um caráter coercitivo - a maior parte das/os estudantes são encaminhadas/os ao serviço de psicologia escolar quando apresentam algum comportamento que incomoda as normas institucionais.

A psicóloga e pesquisadora Raquel Guzzo (2010), em relação à Psicologia Escolar, aponta que "as expectativas de intervenção do psicólogo na rede pública vêm demonstrando que a sociedade ainda espera do profissional a função de ajustar os estudantes ao sistema" (p. 133). Para a autora, no entanto, é preciso colocar tal demanda em questão, pois se apenas respondemos a ela, nos colocamos como reprodutoras/es e legitimadoras/es das relações de desumanização e exclusão instituídas.

Em 1988, a psicóloga Maria Helena de Souza Patto, em seus estudos sobre o fracasso escolar, observou que, ainda que houvesse avanços nas pesquisas sobre a situação da escola e do ensino, atribuir a culpa pelo fracasso escolar ao aluno ainda era uma forte tendência. De acordo com a autora, nesse cenário, o saber psicológico se somava à visão médica organicista da educação para explicar que, além de déficits do estudante, as dificuldades escolares seriam fruto do ambiente em que as crianças viviam.

Como aponta Candau (2011), ao longo da história da educação, identificamos alguns marcos do discurso sobre a diferença no campo pedagógico, dentre os quais o referencial psicológico, das teorias da aprendizagem e psicologia do desenvolvimento. No entanto, o fato de tais teorias focarem em aspectos individuais de caráter psicoafetivo, acabam por apresentar uma concepção de sujeito da aprendizagem bastante limitada, praticamente desconsiderando as dimensões sócio-histórica e cultural. 
Hecket e Barros (2007) lembram que as políticas educacionais nos anos 60 e 70 foram elaboradas a partir de pressupostos da teoria do capital humano, aliados às explicações advindas das teorias da marginalidade e carência cultural. Estes também se constituíram em ferramentas estratégicas na elaboração das políticas sociais de cunho compensatório, que tinham como objetivo conter conflitos sociais. As autoras ressaltam que as teorias da carência ou deficiência cultural, forjadas nos EUA, na década de 40, foram transplantadas para o Brasil na década de 70. Este movimento instituiu, a partir de diagnósticos psicológicos e pedagógicos que apontavam as famílias das camadas populares como pouco capazes de criar seus filhos, programas cujo objetivo era substituí-las.

De acordo com Hecket e Barros, algumas das produções no campo da Psicologia contribuíram para a individualização do desempenho escolar e das desigualdades sociais, já que desenvolveram pesquisas cujo objetivo era a caracterização psicológica dos grupos em desvantagem. Caracterizações que tinham como parâmetro "comportamentos, atitudes, hábitos, estilo linguístico, modos de sociabilidade, entre outras categorias encontradas em grupos sociais de maior poder aquisitivo" (HECKET \& BARROS, 2007, p.114).

Sob uma pretensa neutralidade, normas foram sendo estabelecidas, de modo que um perfil psicológico das famílias e das crianças das camadas populares fixadas em lugar de carência e falta - foi traçado. Tudo que escapasse ao modelo de normalidade instituído era desqualificado, devendo ser mantido sobre atenta vigilância, corrigido e/ou silenciado.

Em minha prática, percebo que o cenário analisado por Patto, Hecket e Barros em diversos aspectos permanece muito semelhante ao que encontramos hoje, ainda que com atualizações. No cotidiano de trabalho, é possível dizer que a maior parte da demanda a/ao profissional de psicologia está relacionada à avaliação de estudantes que apresentam dificuldades na aprendizagem e/ou sociabilidade. Via de regra, são estudantes que se encontram no que se convencionou chamar "distorção idade-ano", isto é, com a faixa etária acima da esperada para o ano escolar que cursam. Ou estudantes que apresentam comportamentos desafiadores, recusando-se a seguir certas normas da escola.

As hipóteses diagnósticas levantadas pelas equipes técnicas para justificar tanto o "atraso" quanto o "mau comportamento" apontam quase sempre para transtornos da aprendizagem e/ou comportamentais. Aos olhos da instituição, 
estas crianças e adolescentes necessitariam de encaminhamentos para diversos tipos de avaliações - psicológicas, neurológicas, fonoaudiológicas, psiquiátricas supostamente capazes de detectar o que as/os fazem ser pouco produtivas/os e/ou agressivas/os na vida escolar. Uma vez identificadas as possíveis causas dos desvios, elas/es devem começar um tratamento para a correção do problema. A/ao psicóloga/o escolar cabe assim fazer a triagem dessas/es estudantes, identificando quais avaliações são necessárias, convocando a família e fazendo os devidos encaminhamentos para o tratamento/correção.

É importante ressaltar que esse tipo de demanda certamente não chega a/ao psicóloga/o apenas em escolas da rede pública. No entanto, neste estudo, esse recorte não é arbitrário. Em uma sociedade marcada historicamente pela desigualdade, espaços educacionais bastante distintos são reservados aos diferentes grupos sociais. Da mesma maneira, os modos de perceber e dar encaminhamento às dificuldades apresentadas por estudantes na escola apresentam diferenças significativas.

O que percebo cotidianamente nas escolas públicas é que, não raro, as demandas por correção das/os "desviantes" chegam sem qualquer consideração sobre o contexto em que são identificadas. Quando muito, contam com uma análise que se reduz a culpabilizar as famílias, identificadas como “desestruturadas", problemáticas e, portanto, também inadequadas, patológicas. A dimensão sociocultural é tida como menos importante e, desta maneira, são apresentadas apenas soluções que giram em torno do sujeito, daquilo que é próprio de sua natureza e que o impede de se adequar à norma (FOUCAULT, 2001, 2009). Ao que parece, é o seu eu, intrapsíquico, que se encontra (ou é por natureza) "degenerado", desadaptado e precisa ser modificado/regenerado para adequar-se ao instituído.

Ao mesmo tempo, quando o contexto sociocultural é levado em conta, isto acontece numa perspectiva que naturaliza as violências em determinados territórios e grupos sociais, denunciando estigmas, preconceitos e, sobretudo, racismo. Não foram poucas as vezes em que recebi queixas de estudantes acompanhadas de comentários que sugeriam que o comportamento mais agressivo da/o estudante era comum em pessoas da comunidade a qual ela/e pertencia. 
Essas práticas também revelam o modo como a colonialidade se faz presente nos discursos e abordagens educacionais na escola hoje. Patto já apontava para essa presença quando concluía que a explicação da produção do fracasso escolar encontra-se calcada no preconceito racial e social, na "força da ideologia num país marcado pelo colonialismo, pela escravidão, pelo modo capitalista de produção e pelas artimanhas culturais que os justificam” (1988, p.77).

Segundo Arroyo (2012), há uma história antipedagógica que persiste e se atualiza desde a empreitada colonizadora. Em sua visão, esta antipedagogia se revela pelos corpos-vidas das infâncias não reconhecidas como parte da história oficial, econômica, cultural e pedagógica. Infâncias apagadas por pertencerem a coletivos sociais raciais inferiorizados e/ou excluídos por essa narrativa, construída pelo grupo que se autodefine superior: o grupo branco de elite. Corpos que desde tenra idade são pensados como não educáveis, não humanos. “A visão e os tratos, até os medos de seus corpos revelam que são vistos como bárbaros, sem limites, agressivos, instintivos. Violentos. Corpos mais do que precarizados, subhumanos" (p. 40).

A triste noticia é que, na verdade, não se trata de uma "antipedagogia", mas de uma pedagogia. Levando em conta a colonialidade do saber, podemos afirmar que o próprio saber pedagógico moderno-colonial em suas bases é racista, sexista e classista e, portanto, é um saber excludente por princípio.

Como aponta Grosfoguel (2012) com a expansão colonial europeia, no século XVI, tiveram origem a geocultura, ou ideologias globais, que ainda constituem os imaginários contemporâneos no que chamou de "sistema-mundo ocidentalizado cristianocêntrico capitalista patriarcal moderno colonial". Foi a expansão colonial que, a nível global, institucionalizou e normatizou não só a supremacia de uma classe, de um grupo étnico-racial, de um gênero, de uma sexualidade, como de um tipo particular de organização estatal e de institucionalização da produção de conhecimento, "de uma epistemologia, de algumas línguas, de uma pedagogia, e de uma economia orientada para a acumulação de capital em escala global" (GROSFOGUEL, 2012, p. 342). 


\subsection{Impactos do racismo na produção de fracasso e abandono escolar}

Os diversos relatórios e pesquisas que trazem dados do imenso número de crianças e adolescentes fora da escola no Brasil (IBGE, 2016; UNICEF, 2017; INEP, 2017), nos mostram que as crianças e adolescentes excluídos da escola pertencem às camadas sociais mais baixas da população e há uma estreita ligação dessa exclusão com a privação de uma série de outros direitos constitucionais (moradia, alimentação, saúde, transporte, lazer, proteção de violências e explorações, etc). Em um ciclo vicioso, meninos e meninas ficam invisíveis às políticas públicas por não conseguirem acessá-las e não as acessam porque estão invizibilizados/as (UNICEF, 2017).

Mas como temos discutido, não podemos pensar as desigualdades sociais que interditam condições básicas de vida para as pessoas das camadas sociais mais pobres apenas pelo viés da desigualdade econômica. A colonialidade que atravessa e constitui a história social e política brasileira exige uma análise mais complexa de suas desigualdades, assim como da criação de estratégias de enfrentamento às suas problemáticas.

O PNAD (IBGE, 2016) aponta que 54\% da população brasileira é composta de negros e pardos, no entanto, se no grupo dos $10 \%$ mais pobres sua participação era de $75 \%$, no $1 \%$ mais rico, era de apenas $17,8 \%$. Estes dados reiteram a afirmação de Bento (2014) de que a pobreza no Brasil tem cor. Mas a autora acrescenta que, ainda que qualquer brasileiro minimamente informado tenha sido exposto a esta informação, há conveniência em não considerá-la, sendo lugar comum limitar o problema a classe social. Esta conveniência não é deliberada, mas calcada no esforço constante e histórico de manutenção dos privilégios do grupo dominante branco.

Para Zamora (2012), reduzir as diversas e complexas dimensões da desigualdade racial à desigualdade de classe (ainda que haja articulação entre elas) é ocultar parte relevante de nossa história. A parte em que conta que o fim da escravidão do povo negro não significou a abolição das condições indignas de vida a que estes eram expostos. Ao contrário, a lógica da exploração escravagista 
se atualiza para continuar operando nos cenários políticos e econômicos subsequentes.

Não é por acaso que os indivíduos das camadas mais pobres do Brasil sejam majoritariamente negros. Nosso país se fundou e se estruturou através de um violento sistema escravocrata racista, que explorou durante quase 400 anos os corpos e as vidas de milhões de negras/os africanas/os sequestradas/os de seu continente para ter sua força de trabalho explorada aqui nas atividades de exploração, agricultura, pecuária e nas tarefas domésticas e também reprodutivas.

Como aponta Nascimento (1978), é por volta de 1530 que as/os africanas/os começam a ser trazidos forçadamente para o Brasil, sendo em 1535 constituído regularmente o comércio dessas pessoas como escravas neste país. Ainda que elas tivessem sido levadas como escravas para todas as regiões do território brasileiro, por quase dois séculos a plantação de cana-de-açúcar e seu processamento as concentraram na região Nordeste do país. Em seguida, as descobertas de metais de alto valor comercial, no século XVIII, no estado de Minas Gerais, deslocaram essa concentração em direção ao sudeste. Assim como aconteceria mais tarde, quando, na primeira metade do século XIX, há uma queda da produtividade das minas e o início do chamado ciclo do café, nos estados do Rio de Janeiro e São Paulo, que promoveu uma nova migração das/os escravizadas/os ainda mais ao sul.

As/os negras/os escravizadas/ao tiveram um papel decisivo para "os começos da história econômica de um país fundado, como era o caso do Brasil, sob o signo do parasitismo imperialista" (NASCIMENTO, 1978, p. 49). Desta maneira, podemos afirmar que nossa estrutura econômica jamais teria se estabelecido sem o trabalho escravo.

$\mathrm{O}$ africano escravizado construiu as fundações da nova sociedade com a flexão e a quebra da sua espinha dorsal, quando ao mesmo tempo seu trabalho significava a própria espinha dorsal daquela colônia. Ele plantou, alimentou e colheu a riqueza material do país para o desfrute exclusivo da aristocracia branca. Tanto nas plantações de cana-de-açúcar e café e na mineração, quanto nas cidades, o africano incorporava as mãos e os pés das classes dirigentes que não se autodegradavam em ocupações vis como aquelas do trabalho braçal. A nobilitante ocupação das classes dirigentes - os latifundiários, os comerciantes, os sacerdotes católicos - consistia no exercício da indolência, o cultivo da ignorância, do preconceito, e na prática da mais licenciosa luxúria (NASCIMENTO, 1978, pp. 49-50). 
Essa história, no entanto, foi, ao longo do tempo, distorcida, através de mentiras e dissimulações. Formulou-se uma narrativa histórica oficial que mascarou a ideologia imperialista, ocultando a violência racista colonial. Um dos principais objetivos disso, como vimos, foi proteger aqueles que a formularam e praticaram, isto é, os sujeitos brancos, mantendo assim seus privilégios de raça e classe.

É somente no fim do século XIX, com o início do período industrial e após diversos movimentos de resistência da população negra contra sua exploração e subalternização, que este tipo de trabalho é legalmente abolido. No entanto, o modo como a abolição da escravatura ocorreu não promoveu uma real integração da população negra, mantendo-a a margem das mudanças estruturais.

Como apontam Soares e Zamora (2019), mesmo após a institucionalização da CLT, em 1943, não houve modificação consistente na situação das/os negras/os. Isto porque, havia um processo de desqualificação de sua mão de obra para a indústria, em relação aos imigrantes europeus, especialmente italianos, que estavam sendo recebidos no território brasileiro justamente para trabalhar nas fábricas. Esse movimento relegou a população negra a "uma história de criminalização e miséria que, por mais que algumas políticas recentes tenham tentado reverter, persiste" (SOARES E ZAMORA, 2019, p. 51).

Como aponta Schucman (2014), a explosão da cultura do café, a partir da primeira metade do século XIX, exigiu um aumento exponencial de mão de obra, fazendo com que a entrada de escravizados no país crescesse significativamente neste período, chegando ao seu auge em 1848, quando desembarcaram no Brasil 60.000 cativos africanos. Mas o fim formal do tráfico de seres humanos para escravização no ano de 1850 e a abolição legal da escravidão em 1888, fez com que no final do século XIX, a mão-de-obra escrava se encontrasse envelhecida. Somado a isso, frente a expansão das lavouras de café, a quantidade de mão-deobra disponível, tanto livre quanto escrava, tornou-se insuficiente.

Nesse período, no Estado de São Paulo, os agricultores paulistas, que se encontravam inseridos na conjuntura política de construção de identidade nacional, optaram pela abertura a mão de obra de imigrantes europeus. Desta 
maneira, no final do século XIX e início do século XX, São Paulo tornou-se um dos maiores polos de imigração do mundo, recebendo, entre 1820 e 1949, 2,5 milhões de imigrantes. De acordo Schucman, esta imigração maciça foi em grande medida política.

Segundo George Andrews (1998), após a abolição e o regime escravista, os negros libertos foram substituídos e preteridos do mercado de trabalho na cidade e no Estado de São Paulo. A imigração cumpria com um duplo objetivo estratégico: branquear e europeizar a cidade e, diante do choque abolicionista, desqualificar a mão-de-obra dos negros (SCHUCMAN, 2014, p. 61).

O momento da abolição da escravatura no Brasil era também um momento mudanças estruturais no país, como a industrialização, a proletarização e a urbanização. Todas essas mudanças implicaram uma ampla discussão entre intelectuais sobre a questão da identidade nacional e o futuro da nação. Surgiam questões importantes sobre o que fazer com a massa de recém-libertos e como transformar a diversidade de populações aqui presentes em uma unidade homogênea, ou seja, um povo e nação únicos (SCHUCMAN, 2014).

No século XIX, o evolucionismo e o determinismo biológico trazem como base do pensamento científico o pressuposto da superioridade/inferioridade. $\mathrm{Na}$ raiz das teorias raciais está a diferenciação entre características físicas e comportamentais que toma cientificamente como referência de normalidade, em uma escala evolutiva, o grupo branco. Há assim uma classificação científica de populações não brancas que corrobora com a hierarquização das relações sociais, legitimando processos de dominação econômica e política e definindo territórios de miséria e exploração.

O Evolucionismo Social de Herbert Spencer, a Eugenia defendida por Francis Galton, a Teoria das Degenerescências proclamada por August Morel, a Craniologia de Cesare Lombroso, entre outras, foram teorias responsáveis pela produção de conhecimento do racismo científico e produtores de práticas, políticas e discursos raciais e discriminatórios. Na maioria dos escritos e em discursos de governantes ocidentais modernos pode ser encontrado o projeto de tornar suas nações livres das raças mestiças e não brancas (Gould, 1991) (SOARES E ZAMORA, 2019, p. 56).

Em seus estudos sobre o poder, Foucault (2005) aponta que o século XVIII marca o processo de entrada dos fenômenos próprios à vida humana nos cálculos do poder. De acordo com ele, nesse momento os processos relacionados à vida humana passam a ser considerados pelos mecanismos de poder e de saber, 
inaugurando uma forma de poder por ele denominada como biopoder, que se desenvolve nos séculos posteriores.

De acordo com Foucault, o biopoder é uma tecnologia que incide sobre a vida, tornando sua gestão controlada muito mais importante do que a exigência da morte. Entretanto, não se trata de uma tecnologia de poder que exclui a anterior, a técnica disciplinar, "mas que a embute, que a integra, que a modifica parcialmente e que, sobretudo, vai utilizá-la implantando-se de certo modo nela, e incrustandose efetivamente graças a essa técnica disciplinar prévia" (FOUCAULT, 2005, p. 289). Ao encarregar-se da vida o poder apropriar-se dos processos biológicos para controlá-los e modificá-los.

Ao investir no corpo vivo, ao valorizá-lo, gerindo de modo distributivo suas forças, o biopoder o inclui de forma controlada nos aparelhos de produção e consumo, sendo, portanto, de grande importância no desenvolvimento do capitalismo. O que se produz em sua atuação não é somente o indivíduo disciplinado, dócil e útil aos interesses capitalistas, mas uma gestão calculada do corpo social, isto é, uma biopolítica.

[...] a disciplina tenta reger a multiplicidade dos homens na medida em que essa multiplicidade pode e deve redundar em corpos individuais que devem ser vigiados, treinados, utilizados, eventualmente punidos. E, depois, a nova tecnologia que se instala se dirige a multiplicidade dos homens, não na medida em que eles se resumem em corpos, mas na medida em que ela forma, ao contrário, uma massa global, afetada por processos de conjunto que são próprios da vida, que são processos como nascimento, a morte, a produção, a doença, etc. Logo, depois de uma primeira tomada de poder sobre o corpo que se fez consoante o modo da individualização, temos uma segunda tomada de poder que, por sua vez, não é individualizante mas que é massificante [...] que se faz em direção não do homemcorpo, mas do homem-espécie. Depois da anátomo-política do corpo humano, instaurada no decorrer do século XVIII, vemos aparecer, no fim do mesmo século, algo que já não é uma anátomo-política do corpo humano, mas que eu chamaria de uma "biopolítica" da espécie humana (FOUCAULT, 2005, p. 289).

Se as disciplinas lidavam praticamente com o indivíduo e com seu corpo, o biopoder lida com um corpo múltiplo. Ele lida com a população, vista ao mesmo tempo como um problema científico e político, biológico e de poder, devendo ser tratada por meio de mecanismos globais para que estados globais de regularidade sejam atingidos.

Nesse processo, Foucault considera que os mecanismos disciplinares e os mecanismos reguladores de poder se articulam. Tal articulação se dá através da norma, um elemento que vai circular entre o disciplinador e o regulamentador, 
permitindo ao mesmo tempo o controle disciplinar do corpo e dos acontecimentos aleatórios de uma multiplicidade biológica, configurando o que Foucault chamou de "sociedade de normalização".

Segundo Foucault, na biopolítica, a comunidade é vista como um conjunto biologicamente homogêneo que, para ser mantido, precisa ser regulado através de políticas não apenas de organização e proliferação da vida, mas também de saneamento, que cumpram a função de livrar o corpo da população de suas infecções internas, suas anomalias e seus contágios. Nesse processo, o racismo é mecanismo fundamental do poder. É ele que vai definir "um corte entre o que deve viver e o que deve morrer" (p. 304).

De acordo com Foucault, a organização e qualificação hierarquizada dos indivíduos em raças tem como função primeira fragmentar o campo do biológico de que o poder se incumbiu, defasando, no interior da população, uns grupos em relação aos outros. Em segundo lugar, ele considera que o racismo tem o papel de permitir uma "relação guerreira", isto é, que parte da ideia de que para viver é preciso eliminar os inimigos. Uma relação que, segundo ele, apesar de não ter sido inventada nem pelo racismo, nem pelo Estado, é colocada em funcionamento pelo racismo de uma maneira precisamente compatível com o exercício do biopoder.

De uma parte, de fato, o racismo vai permitir estabelecer, entre a minha vida e a morte do outro, uma relação que não é uma relação militar e guerreira de enfrentamento, mas uma relação do tipo biológico: "quanto mais as espécies inferiores tenderem a desaparecer, quanto mais os indivíduos anormais forem eliminados, menos degenerados haverá em relação à espécie, mais eu - não enquanto individuo mas enquanto espécie - viverei, mais forte serei, mais vigoroso serei, mais poderei proliferar". A morte do outro não é simplesmente a minha vida, na medida em que seria minha segurança pessoal; a morte do outro, a morte da raça ruim, da raça inferior (ou do degenerado, ou do anormal), é o que vai deixar a vida em geral mais sadia; mais sadia e mais pura (FOUCAULT, 2005, p. 305).

Há, portanto, na visão de Foucault, o estabelecimento de uma relação biológica, em que os inimigos não são adversários no sentido político do termo, mas representam perigos em relação à população e para a população. Desta maneira, no sistema do biopoder, fazer morrer torna-se admissível em função da eliminação do perigo biológico e do fortalecimento da própria raça. Nas palavras do autor, "a raça, o racismo, é a condição de aceitabilidade de tirar a vida numa sociedade de normalização" (p. 306). 
Nessa perspectiva, na Europa, os ideais do racismo científico eram difundidos através das teorias raciais. Afirmava-se cientificamente que a humanidade está dividida em raças e que essa divisão se organiza hierarquicamente. A raça branca, associada a civilidade e ao progresso, assume o lugar mais alto e representa o modelo de humanidade a ser preservado, em detrimento das outras raças degeneradas. Neste sentido, essa produção teórica considerava a ideia da miscigenação como um fator de desqualificação e degeneração da humanidade.

O racismo científico impunha, assim, um entrave para a possibilidade de desenvolvimento da nação brasileira, uma vez que esta era composta em grande parte por negros e mestiços. Diante deste dilema, como aponta Schucman (2014), intelectuais brasileiros como Oliveira Viana, Silvio Romero e Euclides da Cunha buscaram criar teorias que trouxessem o valor positivo da miscigenação para o progresso. Havia uma expectativa de tornar o Brasil um país branco através do cruzamento de raças (BENTO, 2014).

De acordo com Schucman, desse movimento surge a teoria tipicamente brasileira do ideal de "branqueamento", aceita entre 1889 e 1914 pela maioria da elite brasileira.

\begin{abstract}
A tese do branqueamento baseava-se na presunção da superioridade branca, às vezes pelo uso dos eufemismos raças "mais adiantadas" e "menos adiantadas" e pelo fato de ficar em aberto a questão de ser a inferioridade inata. À suposição inicial, juntaram-se mais duas. Primeiro - a população negra diminuía progressivamente em relação à branca por motivos que incluíam a suposta taxa de natalidade mais baixa, a maior incidência de doenças, e a desorganização social. Segundo - a miscigenação produzia "naturalmente" uma população mais clara, em parte porque o gene branco era mais forte e em parte porque as pessoas procuravam parceiros mais claros que elas. (A imigração branca reforçaria a resultante predominância branca). (SKIDMORE, 1976, p. 81 apud SCHUCMAN, 2014, p. $61)$.
\end{abstract}

O ideal do branqueamento moldou a construção de uma identidade nacional baseada na herança branca europeia e na negação de qualquer identidade alternativa, que trouxesse como fundamentado a herança negra africana (MUNANGA, 2004). Os intelectuais que apostavam no branqueamento como salvação da pátria, defendiam que a miscigenação produziria uma população mestiça saudável e capaz de torna-se, tanto cultural quanto fisicamente, progressivamente mais branca. 
Nessa lógica a sexualidade e as capacidades reprodutivas das mulheres negras em particular passam a ser ainda mais alvo de controle e exploração do Estado patriarcal branco. Para embranquecer a população era necessário estimular a procriação interracial, mas era o acesso do homem branco ao corpo da mulher negra que de fato era estimulado e imposto. Ao homem branco não interessava "dividir" as mulheres de sua "raça" com o homem negro, mesmo que a procriação entre eles biologicamente produzisse o mesmo efeito de embranquecimento da população. A imbricação racismo-sexismo nas políticas de branqueamento objetivava aumentar o domínio dos homens brancos não só sobre todas as mulheres, mas sobre toda a população. Não se pode perder de vista que era a aniquilação de todas as populações não brancas o objetivo final dessas políticas.

Um impacto importante da instauração de uma política estatal de branqueamento foi a naturalização da representação negativa das culturas não brancas e a disseminação de uma busca por aceitação por parte destas populações através do modelo brancocêntrico. Em relação ao povo negro, "o embranquecimento legitima, mais uma vez, um não-lugar para o negro na sociedade pós-abolicionista, solidificando-se no imaginário social de forma a atravessar os processos de subjetivação tanto do negro quanto do branco" (SOARES E ZAMORA, 2019, p. 68).

Para Fanon (2008), a relação entre o racismo e a subjetividade é efeito histórico do processo de construção identitária e para o sujeito negro isso significou uma rejeição da sua autoimagem e uma busca pelo embranquecimento, por suas "máscaras brancas". O corpo negro encarna os ideais do homem branco, que solapam sua identidade, levando-o a desejar e projetar o embranquecimento (SANTOS, 1983; VILHENA, 2006). Esse desejo pelo embranquecimento se constrói como um tentativa de inserção e aceitação no mundo dos brancos, que se dá pelas vias da assimilação cultural, da linguagem e das escolhas amorosas (FANON, 2008).

A psicóloga Evelyn Dias Malafaia (2019), em diálogo com Munanga e Ferreira, analisa o quanto o processo de branqueamento pode ter influenciado no processo de desconstrução da identidade racial na/o negra/o, isto é, em seu processo de identificação, impondo grande dificuldade e mesmo impossibilidade 
desta/e viver harmoniosa e prazerosamente com seu corpo. De acordo com a autora, a exaltação das características europeias/brancas e a ridicularização e inferiorização dos traços negróides em nossa sociedade, faz crescer o sentimento favorável à "pigmentocracia" (termo utilizado por Ferreira).

A constatação de que em nossa sociedade há maior valorização social dos sujeitos com características mais próximas ao padrão de beleza do branco europeu e desvalorização e exclusão, em diversas esferas sociais, daqueles com características mais próximas aos traços negros, reforçou a ideia de que a miscigenação seria um processo no qual a/o negra/o se tornaria mais respeitado, possibilitando sua ascensão social. Para a/o negra/o, diante de conceituações científicas que legitimavam sua inferioridade e dos incentivos para a mestiçagem (fusão das "diferentes raças"), embranquecer se tornou um objetivo (MALAFAIA, 2019).

Malafaia aponta que um dos efeitos do racismo e do ideal de branqueamento nas relações entre crianças negras é o chamou de "uma certa competição pigmentocrática" (MALAFAIA, 2019, p. 42). Relembrando sua trajetória escolar, ela aponta que havia uma perceptível competição pigmentocrática entre as crianças negras. "Aquelas mais próximas das características do branco rechaçavam as demais, ainda que não fossem reconhecidas socialmente como brancas" (p. 42).

Esse tipo de competição é de fato perceptível na escola, sendo razão de alguns conflitos entre crianças e adolescentes negros/as. Um caso em especial me vem a recordação ao ler o relato de Malafaia. Foi quando duas adolescentes negras foram levadas por uma coordenadora até minha sala de atendimento em uma escola, por conta de uma briga entre elas na sala de aula.

A coordenadora entrou na minha sala e contou sobre o conflito, pedindo que eu conversasse com as estudantes. Segundo ela, as meninas haviam discutido por conta de uma prova e a discussão acabou em um conflito físico e em xingamentos. No meio da discussão, uma das meninas havia chamado a outra de "puta preta". 
O teor racista e machista do xingamento me alarmou. Mas, para minha surpresa maior, quando as duas meninas entraram na sala, identifiquei ambas como negras (informação que não tinha até então), sendo uma (a que havia feito o xingamento) menos retinta do que a outra.

Conversamos longamente sobre o conflito, suas razões, seus desdobramentos. Problematizei com as duas meninas o caráter machista do xingamento "puta" e o quanto aquilo era ofensivo para as mulheres. No entanto, antes de problematizar o racismo imbricado naquele xingamento, perguntei como cada uma se identificava racialmente. A estudante mais retinta logo afirmou que era negra. A outra ficou em silêncio. Então eu perguntei para esta se ela também se percebia como negra ou não. Ela respondeu, com a cabeça baixa e com os olhos marejados, que sim. Espontaneamente a outra estudante a abraçou e as duas choraram. Quando o abraço terminou, conversamos sobre o racismo e sobre a dor por ele provocada. Elas conversaram. Falaram sobre como era dolorido a cor de suas peles ser motivo de xingamento e sobre o porquê da estudante mais clara ter utilizado deste xingamento para agredir a outra.

Eu nunca tinha ouvido falar em pigmentocracia, nem elas. Não utilizamos esse termo em nenhum momento. Mas hoje percebo que foi sobre a pigmentocracia e seus impactos destrutivos que discutimos naquele momento.

Kilomba (2019), assim como Fanon (2008), considera que um dos efeitos da invenção e imposição de uma negritude pautada naquilo que o sujeito branco nega em si e projeta no sujeito negro é produzir uma espécie de pré-programacão do inconsciente coletivo das pessoas negras para a alienação, decepção e trauma psíquico. Isto porque estas imagens da negritude às quais são confrontadas/os não são nada realistas e muitos menos gratificantes. Desta forma, ela compreende que as experiências cotidianas de racismo, vivenciadas pelo sujeito negro, precisa e violentamente o retiram e separam de qualquer identidade que ele possa realmente ter.

Para Kilomba, nessa separação produz-se um trauma clássico, pois através dela o individuo é privado de sua própria conexão com a sociedade, inconscientemente pensada como branca. Ela problematiza:

Parece, portanto, que o trauma de pessoas negras provém não apenas de eventos de base familiar, como a psicanálise argumenta, mas sim do traumatizante contato com a violenta barbariedade do mundo branco, que é a irracionalidade do 
racismo que nos coloca sempre como a/o "Outra/o", como diferente, como incompatível, como conflitante, como estranha/o e incomum (KILOMBA, 2019, p. 40).

Em um dos encontros com estudantes em que discutimos o racismo, iniciamos a roda assistindo a série web-documentária chamada "Raiz Forte" ${ }^{48}$. Neste encontro teríamos a participação de duas educadoras, sendo uma delas coordenadora pedagógica da escola,ambasmulheres negras e ativistas antirracistas, que haviam aceitado o convite para mediarmos juntas a discussão. Este convite foi feito a partir da compreensão de que como branca, minha crítica ao racismo se constrói do lugar de quem, por mais solidária que seja aos que são vítimas do racismo, nunca o sofreu. Essa perspectiva foi compartilhada com as educadoras e juntas pensamos sobre a importância da sua presença no sentido de trazer a dimensão da experiência de quem sofre o racismo e vem ao longo da sua trajetória resistindo. Consideramos que essa referência era muito importante para acolher as possíveis questões que essa temática suscitaria nas/os estudantes. No entanto, no dia da roda de conversa, apenas a educadora que era também coordenadora pode participar, em função de imprevistos.

Depois de assistirmos a série, formamos uma roda de debate, como costumávamos fazer. Era notável o desconforto que aquela temática, mais do que as anteriores, trouxera. Após a exibição da série, uma das estudantes tinha lágrimas nos olhos. Perguntei se ela gostaria de expor o motivo de sua emoção. Ela respondeu que havia alisado o cabelo a vida inteira, pelos mesmos motivos expostos pelas entrevistadas. No entanto, ela nunca tinha refletido sobre a relação da necessidade que sentia de ter o cabelo liso com o racismo que sofria. Agora que tinha sido chamada atenção para isto pelo depoimento das meninas e mulheres entrevistadas no vídeo, disse que se sentia triste ao se dar conta do que estava envolvido na sua "briga" (sic.) com o seu cabelo natural.

Após sua colocação, me mostrei solidária e acolhedora, e isso teve um efeito importante e necessário. No entanto, foi perceptível a importância da coordenadora naquele momento. Quando esta compartilhou suas experiências sobre a mesma questão que a estudante, outro tipo de acolhimento ocorreu, de

\footnotetext{
${ }^{48}$ Em três episódios,esta série contém registros e relatos de mulheres negras (crianças, adolescentes e adultas), residentes no estado do Espírito Santo, sobre a estética afrodescendente no âmbito familiar, escolar, afetivo e de militância.
} 
caráter mais profundo. A possibilidade de identificação e troca de experiência com a educadora que vivenciava algo muito próximo ao que a estudante vivia dava a ela notadamente uma contingência diferenciada e muito importante. Penso que uma das razões disso é que tratávamos de um trauma forjado pelo racismo e, portanto, apesar de produzir efeitos singulares em cada corpo-vida, por suas trajetórias pessoais, falava de uma coletividade, de uma população que vem sistematicamente sendo violentada e resistindo por gerações.

Por todas as (des)razões já elencadas, em uma sociedade racista, o corpo negro é visto de modo pejorativo em relação ao branco, sendo sempre desfavoravelmente comparado aos ideais estéticos eurocêntricos. Como apontam Souza (1983) e Zamora (2012), este olhar incide sobre a relação que negras/os estabelecem com seu próprio corpo, que passa de uma relação de alegria e prazer, para uma relação de insatisfação e monitoramento, que se dá no sentido de um esforço constante em encobrir as características que o tornam destoante do modelo imposto. Um exemplo típico disto é a visão do cabelo crespo como um cabelo "ruim" e o cabelo liso, como o cabelo "bom". Como explicitado pela estudante, esta visão impõe às meninas negras, ainda pequenas, uma necessidade aparentemente "natural" de realizar procedimentos químicos capazes de deixar o cabelo o mais liso possível.

Kilomba (2019), ao tratar das políticas do cabelo, deflagra o caráter racista dos comentários e acessos ao corpo negro a partir do cabelo. Desde a infância, pessoas negras tem de lidar com pessoas brancas tocando e fazendo perguntas e comentários ambíguos sobre o seu cabelo "diferente", que vão de supostos "elogios" à questionamentos sobre sua higiene. Para a autora, essas abordagens se constituem a partir das fantasias da branquitude sobre a negritude.

De acordo com Kilomba, historicamente, o cabelo das pessoas negras foi tido como o mais visível estigma da negritude, sendo utilizado para justificar a subordinação de africanas/os mais do que a cor da pele.

[...] o cabelo tornou-se a mais poderosa marca de servidão durante o período de escravização. Uma vez escravizada/o, a cor da pele de africanas/os passou a ser tolerada pelos senhores brancos, mas o cabelo não, que acabou se tornando um símbolo de "primitividade", desordem, inferioridade e não-civilização. O cabelo africano foi então classificado como "cabelo ruim". Ao mesmo tempo, negras e negros foram pressionadas/os a alisar o "cabelo ruim" com produtos químicos 
apropriados, desenvolvidos por indústrias europeias. Essas eram formas de controle e apagamento dos chamados "sinais repulsivos" da negritude (p. 127).

Ao mesmo tempo, nesse contexto, o cabelo se tornou uma ferramenta importante da consciência política entre africanas/os e africanas/os em diáspora. Através dos dreadlocks, rasta, "blacks" ou penteados africanos, transmite-se uma mensagem política de pertencimento e fortalecimento racial, bem como de resistência à opressão racial.

Nesse sentido, os ataques e ofensas ao cabelo negro são também políticos. Como aponta Kilomba, as respostas de desaprovação a redefinição política de si pelas pessoas negras através de cabelos naturais revelam a ansiedade branca de perder o controle sobre a/o colonizada/o. Elas alertam que essas pessoas estão mostrando muitos sinais de negritude, o que pode significar "sinais de independência e descolonização em relação às normas brancas, um fato perturbador para o público branco" (pp. 127-128). Para a autora, existe uma relação entre consciência racial e descolonização do corpo negro, assim como entre as ofensas racistas e a dominação do corpo negro.

Gomes (2002), considera que para ampliar o estudo da questão racial no campo da educação, na tentativa de compreender a sua relação com o universo simbólico, um dos caminhos pode ser "a construção de um olhar mais alargado sobre a educação como processo de humanização, que inclua e incorpore os processos educativos não-escolares" (p. 40). De acordo com ela, este movimento possibilita captar as impressões, representações e opiniões dos sujeitos negros sobre a escola. Dentre as temáticas a serem eleitas e aprofundadas nesse processo, a autora destaca a relação do negro com o corpo e o cabelo, isto porque:

As diferentes crenças e sentimentos, que constituem o fundamento da vida social, são aplicadas ao corpo. Temos, então, no corpo, a junção e a sobreposição do mundo das representações ao da natureza e da materialidade. Ambos coexistem de maneira simultânea e separada. Por isso, não podemos apagar do corpo os comportamentos e motivações orgânicas que se fazem presentes em todos os seres humanos, em qualquer tempo e lugar. A fome, o sono, a fadiga do corpo, o sexo são motivações biológicas às quais a cultura atribui uma significação especial e diferente. É a cultura que, à sua maneira, inibirá ou exaltará esses impulsos, selecionando dentre todos quais serão os inibidos, quais serão os exaltados e ainda quais serão os considerados sem importância e, portanto, tenderão a permanecer desconhecidos. Assim, a cultura dita normas em relação ao corpo, às quais o indivíduo tenderá a conformar-se à custa de castigos e recompensas, até o ponto de estes padrões de comportamento apresentarem-se tão naturais quanto o desenvolvimento dos seres vivos ou o pôr-do-sol (Rodrigues, 1986, p. 45) (GOMES, 2002, pp. 41-42) 
De acordo com Gomes, o modo como a escola e a sociedade de modo geral, enxergam a/o negra/o e emitem opiniões sobre o seu corpo e sua estética marcam profundamente suas vidas. Com frequência, apenas quando se distanciam da escola ou acessam espaços onde a questão racial é tratada de maneira positiva é que conseguem falar sobre suas experiências e impressões em relação a temas tão delicados que tocam a sua subjetividade.

Gomes considera que, ao privilegiar a questão racial, o discurso pedagógico não gira apenas em torno de conceitos, disciplinas e saberes escolares, mas aborda o sujeito negro na sua totalidade (pertencimento étnico, condição socioeconômica, cultura, grupo geracional, sexualidade). Para a autora, isso ocorre de modo consciente e inconsciente, sendo muitas vezes, através desse discurso que se reproduzem estereótipos e preconceitos sobre o corpo negro. Ela pergunta: Será que eles são superados? E responde:

O discurso pedagógico proferido sobre o negro, mesmo sem referir-se explicitamente ao corpo, aborda e expressa impressões e representações sobre esse corpo. O cabelo tem sido um dos principais símbolos utilizados nesse processo, pois desde a escravidão tem sido usado como um dos elementos definidores do lugar do sujeito dentro do sistema de classificação racial brasileiro. Essa situação não se restringe ao discurso. Ela impregna as práticas pedagógicas, as vivências escolares e socioculturais dos sujeitos negros e brancos. É um processo complexo, tenso e conflituoso, e pode possibilitar tanto a construção de experiências de discriminação racial quanto de superação do racismo (p. 43).

No momento do encontro para discutir o racismo com as/os estudantes, nosso grupo já havia estabelecido um vínculo importante de afeto e confiança. Mas pensar essa corporeidade é perceber que não era disso que se tratava apenas. Os corpos brancos e negros são marcados de modos muito diferentes em uma sociedade racista e isso tem um impacto nas relações. Por mais solidária que me colocasse diante do sofrimento da estudante, no momento que ela acessava o trauma do racismo, tomando consciência do seu impacto no corpo e na construção de sua autoimagem, meu corpo branco representava a imagem justamente daquilo que a ameaçava e violentava. E então era eu que começava a me dar conta de que, para descolonizar nossos discursos, práticas e abordagens de cuidado, é condição fundamental incluir os corpos, o que eles representam, o que eles informam. Essa sensibilidade é imprescindível para que possamos construir espaços e saberes de fato acolhedores. 
Trazendo de modo muito sensível sua própria experiência, Fanon (2008) afirma que no mundo do branco, as pessoas não brancas encontram sérias dificuldades na elaboração de seu esquema corporal, visto que "o conhecimento do corpo é unicamente uma atividade de negação. É um reconhecimento em terceira pessoa. Em torno do corpo reina uma atmosfera densa de incertezas" (p. 104). Ele descreve esse processo da seguinte maneira:

Elaborei abaixo do esquema corporal, um esquema histórico-racial. Os elementos que utilizei não me foram fornecidos pelos "resíduos de sensações e percepções de ordem sobretudo táctil, espacial, cinestésica e virtual", mas pelo outro, o branco, que os teceu para mim através de mil detalhes, anedotas, relatos. Eu acreditava estar construindo um eu fisiológico, equilibrando o espaço, localizando as sensações, e eis que exigiam de mim um suplemento. [...] Então o esquema corporal, atacado em vários pontos, desmoronou, cedendo lugar a um esquema epidérmico racial. No movimento, não se tratava mais de um conhecimento de meu corpo na terceira pessoa, mas em tripla. No trem, ao invés de um, deixavamse dois, três lugares. Eu já não me divertia mais. Não descobria as coordenadas febris do mundo. Eu existia em triplo: ocupava determinado lugar. Ia ao encontro do outro... e o outro, evanescente, hostil mas não opaco, transparente, ausente, desaparecia. A náusea... [...] Eu era ao mesmo tempo responsável pelo meu corpo, responsável pela minha raça, pelos meus ancestrais. Lancei sobre mim um olhar objetivo, descobri minha negridão, minhas características étnicas, - e então detonaram meu tímpano com antropofagia, com atraso mental, o fetichismo, as taras raciais, os negreiros, e sobretudo com “y'a bom banania” (pp. 104-106).

E continua:

Eu era odiado, detestado, desprezado, não pelo vizinho da frente ou pelo primo materno, mas por toda uma raça. Estava exposto a algo irracional. Os psicanalistas dizem que não há nada mais traumatizante para a criança do que o contato com o racional. Pessoalmente eu diria que, para um homem que só tem como arma a razão, não há nada mais neurotizante do que o contato com o irracional (p. 110).

Moore (2007), considera que o racismo corresponde a uma forma específica de ódio, pois dirige-se particularmente a uma parte da Humanidade, identificada a partir de seu fenótipo. É o fenótipo negro que suscita um ódio profundo, cujas raízes encontram-se na memória esquecida da Humanidade, remetendo a conflitos longínquos. De acordo com o autor, esta característica faz com que esse ódio deixe de ser uma questão de sentimento entre indivíduos para se tornar um sistema normativo da realidade social. Trata-se de uma forma de ódio grupal que estrutura a sociedade, sendo responsável por promover, nas sociedades chamadas modernas, "a gestão racializada e monopolista dos recursos da sociedade, tanto em nível nacional quanto em nível planetário” (p. 283). 
Para Kilomba (2019), o racismo, diferente de outras discriminações, é a combinação entre preconceito e poder (histórico, político, social e econômico). Neste sentido, ela considera que só quem tem poder na hierarquia racial é racista e, portanto, o racismo é a supremacia branca.

Outros grupos raciais não podem ser racistas nem performar o racismo, pois não possuem esse poder. Os conflitos entre eles ou entre eles e o grupo dominante branco têm que ser organizados sob outras definições, tais como o preconceito. O racismo, por sua vez, inclui a dimensão do poder e é revelado através de diferenças globais na partilha e no acesso a recursos valorizados, tais como representação política, ações políticas, mídia, emprego, educação, habitação, saúde, etc. Quem pode ver seus interesses políticos representados nas agendas nacionais? Quem pode ver suas realidades retratadas na mídia? Quem pode ver sua história incluída em programas educacionais? Quem possui o que? Quem vive onde? Quem é protegida/o e quem não é? (p. 76).

De acordo com Kilomba, o racismo é revelado no nível estrutural, institucional e cotidiano. Esses três níveis encontram-se entrelaçados, mas operam de maneiras específicas.

O nível estrutural do racismo diz respeito as estruturas sociais e políticas que operam historicamente privilegiando seus sujeitos brancos e colocando os sujeitos pertencentes aos outros grupos raciais em evidente desvantagem, à margem das estruturas dominantes. No nível institucional, o racismo opera através de um padrão de tratamento desigual em sistemas e agendas educacionais, nos mercados de trabalho, nas instituições jurídicas, entre outros, que colocam, mais uma vez, sujeitos brancos em vantagem em relação aos sujeitos negros e não brancos. "O racismo institucional ou sistêmico opera de forma a induzir, manter e condicionar a organização e a ação do Estado, suas instituições e políticas públicas - atuando também nas instituições privadas, produzindo e reproduzindo a hierarquia racial" (GELEDÉS, 2016, p. 17).

A respeito do racismo estrutural e institucional, o jurista e filósofo brasileiro Silvio Almeida (2018) aponta que:

[...] as instituições reproduzem as condições para o estabelecimento e a manutenção da ordem social. Desse modo, se é possível falar de um racismo institucional, significa que, de algum modo, a imposição de regras e padrões racistas por parte da instituição é de alguma maneira vinculada à ordem social que ela visa resguardar. Assim como a instituição tem sua atuação condicionada a uma estrutura social previamente existente - com todos os conflitos que lhes são próprios -, o racismo que esta instituição venha a expressar é também parte desta mesma estrutura. As instituições são apenas a materialização de uma estrutura 
social ou de um modo de socialização que tem o racismo como um de seus componentes orgânicos. Dito de modo mais direto: as instituições são racistas porque a sociedade é racista. (ALMEIDA, 2018, p. 36)

Por fim, no nível cotidiano, o racismo opera através de um conjunto de vocabulários, discursos, imagens, ações e olhares que colocam constantemente os sujeitos negros em posições subalternas. Kilomba (2019) considera que no racismo cotidiano "a pessoa negra é usada como tela para projeções do que a sociedade branca tornou tabu" (p. 78), tornando-se um depósito dos medos e fantasias brancas do domínio da agressão ou da sexualidade. Ao serem reprimidos e reprojetados massivamente em "outros" grupos raciais, esses dois aspectos da "agressão" e da "sexualidade" - que em termos freudianos categorizam a organização psicológica de um indivíduo - têm possibilitado ao sujeito branco escapar de sua historicidade de opressão e se construir como "civilizado" e "decente". Ao mesmo tempo, as/os "Outras/os" raciais são tornadas/os “incivilizadas/os" (agressão) e "selvagens" (sexualidade).

A psiquiatra e psicanalista brasileira Neusa Souza Santos (1983) considera que a superpotência sexual é um dos estereótipos que atribui ao negro a supremacia do biológico. Segundo a autora, ela reafirma sua representação de animalidade, "em oposição à sua condição histórica, à sua humanidade" (p. 31).

Para Jesus (2018), o "racismo à brasileira" se expressa por meio de um "racismo institucionalizado", o que significa dizer que foi enquanto prática social que as práticas de hierarquização racial foram instituídas e vem sendo cotidianamente atualizadas, ainda que não adotadas oficialmente pelo Estado. Como aponta o autor, é a perpetuação desses imaginários sobre a suposta inferioridade da "raça" negra que vem contribuindo para a produção e reprodução das discriminações e desigualdades, tanto por meio da estereotipização da população negra, quanto do silenciamento ou da invizibilização das referências positivas relativas à população negra. Assim, devemos compreender o racismo como um sistema de opressão e produção sistemática "de discriminações e desigualdades que, baseando-se na crença acerca da existência de raças superiores e inferiores (intelectual, cultural e socialmente), distribui, de modo assimétrico, privilégios e desvantagens" (JESUS, 2018, p. 4). 
Observamos que em todos os níveis o racismo historicamente atravessa e constitui a escola. Desta maneira, ele é uma linha de força que não pode ser ignorada nas análises sobre a produção do fracasso e abandono escolar. Sem considerar este fenômeno e seus nocivos efeitos sociais e subjetivos nos colocamos reproduzindo o silenciamento e, consequentemente, a opressão racial.

A despeito do amplamente disseminado discurso de "cordialidade", como visto, o Brasil é um país racista. A forte concentração de homicídios na população negra explicita a profunda desigualdade racial existente em nosso país. De acordo com o Mapa da Violência de 2012, entre 2002 e 2010, morreram assassinados no país 272.422 cidadãos negros, com uma média de 30.269 assassinatos ao ano. Enquanto o número de homicídios brancos caiu 25,5\% de 2002 para 2010, o de homens negros aumentou 29,8\%, chegando a um total de 34.983 mortes em 2010. Neste mesmo ano, para cada branco vítima de homicídio proporcionalmente morreram 2,3 negros pelo mesmo motivo.

A pesquisa aponta que até os 12 anos de idade não há diferenças significativas de taxas de homicídio entre brancos e negros. Mas a partir dessa idade, inicia-se um acentuado crescimento da violência homicida até os 20/21 anos de idade das vítimas. Apesar deste crescimento ser observado tanto para brancos quanto para negros, para os últimos o incremento é marcadamente maior. Se entre os 12 e os 21 anos de idade as taxas brancas passam de 1,3 para 37,3 em cada 100 mil, aumentando 29 vezes, as taxas negras passam de 2,0 para 89,6, aumentando 46 vezes.

Os dados levantados pelo Atlas da Violência de 2018, elaborado pelo Instituto de Pesquisa Econômica Aplicada (Ipea) e pelo Fórum Brasileiro de Segurança Pública, apontam no mesmo sentido, constatando que, em 2016, duas vezes mais negros foram assassinados do que não negros ${ }^{49}$. No que se refere às mulheres, os homicídios entre mulheres negras atinge uma taxa $71 \%$ maior do que entre as não negras. Entre 2006 e 2016, para cada 100 mil mulheres negras a taxa de homicídios subiu $15,4 \%$, enquanto entre as não negras caiu $8 \%$. Como

\footnotetext{
${ }^{49}$ Esta pesquisa considera negros as pessoas pretas e pardas e não negros as pessoas brancas, amarelas e indígenas.
} 
apontado no próprio relatório, em relação à violência letal, é como se negros e não negros vivessem em países completamente diferentes (CERQUEIRA et al, 2018).

Esse relatório cita ainda dados de duas outras pesquisas que são também reveladores do grave cenário de desigualdade racial no Brasil. Uma delas é o Índice de Vulnerabilidade Juvenil à Violência, de 2015, que demonstrou que um jovem negro corre 2,7 mais risco de ser vítima de homicídio no Brasil do que um jovem branco. A outra, o Anuário Brasileiro de Segurança Pública, que analisou 5.896 boletins de ocorrência de mortes decorrentes de intervenções policiais entre 2015 e 2016 e, sem contabilizar as vítimas cuja informação de raça/cor não estava disponível, identificou que das vítimas de atuação da polícia 76,2\% são negras.

Esses dados evidenciam a seletividade que há nessas mortes, que tem como marco principal a cor da pele dos indivíduos. Seletividade que não ocorre apenas nos casos de homicídio, mas no acesso a bens de consumo e políticas públicas de garantia básica de vida, como a escolarização.

No que diz respeito às taxas de analfabetismo, o PNAD Contínua de 2016, indica que entre pretos e pardos ela atinge um percentual de 9,9\%, isto é, mais do que o dobro da de brancos que é de 4,2\%. Já em 2017, o PNAD Contínua apontou que enquanto $22,9 \%$ dos brancos com 25 ou mais anos de idade chegam a acessar o ensino superior, esta taxa para os negros e pardos despenca para menos da metade, representando apenas 9,3\%. De modo geral, entre pretos e pardos de 15 anos a média de anos de estudos é de 8,7 e entre brancos é de 10,3.

A pesquisa “Acesso, permanência, aprendizagem e conclusão da Educação Básica na idade certa - Direito de todas e de cada uma das crianças e dos adolescentes", realizada pela Unicef (2012) aponta que um dos principais obstáculos enfrentados pelos estudantes na garantia do acesso e permanência na escola é a discriminação racial. Em todos os indicadores de acesso à escola e conclusão levantados por este estudo, as crianças e os adolescentes negros aparecem em desvantagem em relação aos mesmos grupos etários correspondentes da população branca. Os dados levantados indicam que a média de anos de estudo da população negra é de 6,7 anos enquanto a da população branca é de 8,4, demonstrando que as taxas de repetência e abandono escolar é 
maior entre as crianças e adolescentes negros, o que evidencia a discriminação racial como fator de interferência significativa no rendimento escolar dos alunos do Ensino Fundamental.

A pesquisa traz ainda dados da Relatoria Nacional do Direito Humano à Educação (INEP, 2007 apud UNICEF, 2012), que revelam que enquanto 70\% das crianças brancas conseguem concluir o Ensino Fundamental, apenas 30\% das negras chegam ao final dessa etapa. Ainda que expressivos, esses números "não são capazes de dimensionar a sutileza da discriminação e de mensurar o impacto negativo que ela exerce sobre o desempenho escolar" (UNICEF, 2012, p, 16).

Fazendo um levantamento de pesquisas que analisam dados sobre o acesso e permanência escolar, Jesus (2018) demonstra a persistência da desigualdade racial no Brasil. Como aponta o autor, tais dados revelam a manutenção, ao longo da história, da assimetria na distribuição de bens entre os diferentes grupos raciais.

Uma das pesquisas analisadas por Jesus é a de Henriques, que se refere às condições de vida da população negra ao longo da década de 1990, baseando-se em dados da Pesquisa Nacional por Amostra de Domicílios (PNAD) de 1992 a 1999. Nestas análises, Henriques destaca a dimensão racial das desigualdades brasileiras. De acordo com Jesus, esse autor encontra e reforça os mesmos achados de Pastore e Valle Silva, que apontam que, articulada às formas usualmente "sutis" de discriminação racial, a intensa desigualdade racial brasileira não permite o desenvolvimento das potencialidades e o progresso social da população negra.

Para Henriques é a heterogeneidade na escolaridade brasileira que explica em grande parte a desigualdade econômica e no mercado de trabalho. Ele atenta para o fato de que mesmo com o aumento da oferta de educação no Estado brasileiro ao longo do século $\mathrm{XX}$, a desigualdade no acesso a esse bem não foi verdadeiramente superada.

De acordo com Jesus, os dados de Henriques revelam, além da diferença em termos de anos de escolaridade entre negras/os e brancas/os, a evolução histórica e o grau de cristalização da discriminação racial.

Sabemos que a escolaridade média dos brancos e negros tem aumentado de forma contínua ao longo do século XX. Contudo, um jovem branco de 25 anos tem, em média, mais 2,3 anos de estudo que um jovem negro na mesma idade, e essa intensidade da discriminação racial é a mesma vivida pelos pais desses jovens - a 
mesma observada entre seus avós (HENRIQUES, 2001, p. 30 apud JESUS, 2018, p. 5).

Jesus aponta que, no que se refere às desigualdades educacionais, os resultados obtidos por Henriques unem-se às conclusões das pesquisas realizadas por Nelson do Valle Silva e José Pastore e Carlos Hasenbalg, também baseadas nas Pnad's. De acordo com o autor, todos esses estudos sinalizam a permanência das desigualdades raciais no processo de estratificação social, assim como no acesso à escolarização formal.

Trazendo ainda o resultado das pesquisas de Valverde e Stocco, Jesus aponta que a desigualdade educacional entre negros e brancos parece ter encontrado seu ponto de inflexão em 2002, quando pela primeira vez, desde que a PNAD passou a coletar o quesito cor/raça, a diferença entre as taxas de escolaridade de negros e brancos ficou abaixo de dois anos. De acordo com Valverde e Stocco, esse dado demonstra que a universalização do acesso à educação básica promovida na década de 1990 foi certamente benéfica à população negra. No entanto, concluem que nos últimos anos, a problemática das desigualdades raciais do acesso à educação sofre um deslocamento para o diagnóstico do interior do sistema educacional, visto que as particularidades das experiências vivenciadas por crianças e jovens brancos e negros na escola influenciam diretamente permanência, progressão e desempenho escolar.

É essa dificuldade que a discriminação racista impõe às crianças negras e não brancas da dar continuidade a vida escolar que deve ser também considerada nas análises sobre a produção do fracasso e do abandono escolar. As diferenças significativas entre a média de anos de estudo da população branca e não branca, somadas às mais altas taxas de repetência e abandono entre jovens negros, nos levam a considerar que a discriminação racial interfere de forma significativa no rendimento escolar das/os estudantes.

A dissertação da educadora Fernanda Dias (2011) intitulada "Sem querer você mostra seu preconceito", apresenta um estudo sobre as relações raciais entre jovens estudantes negros de uma escola de Ensino Médio localizada na Região Metropolitana de Belo Horizonte, Estado de Minas Gerais. No decorrer da análise de Dias fica evidente o papel que o imaginário social racista exerce sobre as relações estabelecidas por jovens no ambiente escolar. 
Dias observa que o modo como as/os estudantes dão sentido às relações e elaborações a respeito da questão racial no interior da sala de aula se relaciona com o silenciamento desta questão neste espaço. A negação do racismo no ambiente escolar faz com que jovens adentrem a escola "munidos das diversas representações de cunho racial racialistas, por vezes, fortemente pejorativas e, até mesmo, racistas" (p. 238), que não serão problematizadas e desconstruídas pela escola. Como aponta a autora, tais representações instituem uma desvantagem simbólica que incide em maior grau sobre aquelas/es que apresentam traços fenotípicos de ascendência negra mais acentuados, como a pele mais retinta e o cabelo crespo.

É pertinente considerar ainda que, muitas vezes, o que ocorre nas instituições educacionais é justamente o contrário. Ou seja, há um reforço das representações racistas, através de abordagens pedagógicas, psicopedagógicas, psicológicas, educacionais e curriculares fundadas na colonialidade. É importante destacar isto para que esse aparente "silêncio" da escola em relação à questão racial, as representações negativas que o racismo impõe aos corpos-vidas negros, não se confunda com uma posição neutra, justificada pelo discurso de que a educação é uma instituição que enxerga e trata todas/os as/os estudantes igualmente. O discurso da neutralidade, na verdade, invisibiliza e reforça assimetrias veladas, porém praticadas. Não há neutralidade no silêncio em relação ao racismo.

Um exemplo frequente disso é a prática de nomear como "bullying" atos racistas entre estudantes. Demandas à psicologia escolar relacionadas às ações de prevenção e combate ao bullying têm sido cada vez mais comuns e quase sempre, entre as situações narradas pelas equipes escolares, existem muitas que, na verdade, correspondem a exercícios de poderes estruturantes de nossa sociedade, como o racismo. Nestes casos, é fundamental que a/o psicóloga/o escolar compreenda e discuta com a equipe as diferenças entre uma situação e outra.

Contribuir para uma análise mais complexa das relações sociais, que considera os sistemas de dominação que estruturam nossa sociedade e produzem subjetividade, é papel da/o psicóloga/o. Essa compreensão é fundamental para romper com o silêncio e a negação do racismo na escola. Ela possibilitará a formulação de estratégias pedagógicas e educacionais que abandonam um olhar individualizante - que identifica atos violentos e constrangedores meramente 
como um caso isolado de "um/a estudante problemático/a" contra outro/a, por exemplo -, e se voltam a desconstrução de mentalidades de dominação e subalternização, capazes de promover de fato transformações sociais. 


\section{CAPÍTULO 5. ABANDONO ESCOLAR COMPULSÓRIO DE MENINAS}

\subsection{Brasil: um país perigoso para mulheres}

O Brasil é um país perigoso para mulheres. Com base em dados de 2013 do Ministério da Saúde, a Organização Mundial da Saúde (OMS) aponta que nosso país tem a quinta maior taxa de feminicídios do mundo - 4,8 para 100 mil mulheres. Apontando na mesma direção, o Mapa da Violência de 2015 revela que, entre 1980 e 2013, 106.093 pessoas morreram no país devido a sua condição de mulher. O número de mulheres mortas violentamente, entre 2003 e 2013, passou de 3.937 para 4.762 - uma média de 13 feminicídios por dia - registrando um aumento de $21 \%$ em dez anos. Do total de crimes de feminicídios registrados em 2013, 33,2\% foram praticados por parceiros ou ex-parceiros das vítimas.

Em relação às mulheres negras a situação de agrava. Essa mesma pesquisa aponta que as taxas de homicídio de meninas e mulheres negras na década analisada (2003 a 2013) aumentaram 19,5\%, passando de 4,5 para 5,4 por 100 mil. Em 10 anos foi registrado um aumento de 190,9\% na vitimização de mulheres negras. Se em 2003 a vitimização de negras era de 22,9\%, em 2013 sobe para $66,7 \%$. Neste ano, proporcionalmente ao tamanho das populações de mulheres brancas e negras, estas morreram assassinadas $66,7 \%$ mais do que aquelas.

O Atlas da Violência de 2018 aponta que, entre 2006 e 2016, houve um aumento de 6,4\% na taxa de homicídios de mulheres, chegando em 2016 a uma taxa de 4,5 homicídios para cada 100 mil brasileiras. De acordo com o relatório, apesar da base de dados do Sistema de Informações sobre Mortalidade não fornecer informação sobre feminicídio e por isso não ser possível identificar a parcela que corresponde a vítimas desse tipo específico de crime, sabe-se que a mulher que se torna vítima fatal, em geral, foi vítima de uma série de outras violências anteriormente. Violência psicológica, patrimonial, física ou sexual são algumas delas, que se fossem realmente combatidas poderiam evitar muitas mortes. 
A exploração sexual - constituída pelas modalidades correlatas, turismo sexual, tráfico, pornografia e prostituição (SILVESTRINI, 2014) - é outra questão grave que afeta majoritariamente as mulheres. A partir de dados divulgados, em 2002, pela PESTRAF (Pesquisa sobre o Tráfico de Mulheres, Crianças e Adolescentes para Fins de Exploração Sexual Comercial no Brasil), Silvestrini (2014) demonstra que o Brasil é originário da maioria das pessoas traficadas para fins de exploração sexual. Segundo a pesquisa, o maior índice de vítimas é do sexo feminino, negra, de faixa etária entre 15 e 30 anos, solteira, com baixa escolaridade, desempregada ou exercendo atividades informais, periférica e mãe. Com frequência são mulheres que sofreram algum tipo de violência intrafamiliar (abuso sexual, estupro, gravidez precoce, negligência, abandono, maus tratos, violência física e psicológica) e extrafamiliar (na rua, nas instituições educacionais e/ou de assistência social, nas redes de exploração sexual, etc.).

Ao mesmo tempo, o levantamento do Ministério da Justiça e do Escritório das Nações Unidas sobre Drogas e Crime (UNODC), de 2004, aponta que os aliciadores são majoritariamente homens, na faixa etária de 30 anos, casados, com grau de escolaridade entre o nível médio e o superior. Tratam-se predominantemente de "brasileiros que se dizem empresários, atuando no ramo de casas de shows, bares, casas de encontros associados a um conjunto de negócios escusos, isto é, lavagem de dinheiro, drogas, contrabando, entre outros" (SILVESTRINI, 2014).

A prostituição vem hegemonicamente sendo posta como "um trabalho como outro qualquer". Este argumento tem sido utilizado, inclusive por setores políticos de esquerda, na defesa de sua regulamentação como a venda de um serviço realizado a partir de uma livre escolha e, portanto, com o consentimento das "trabalhadoras". Mas como pensar o consentimento em um sistema estruturado pela hierarquia sexual que subalterniza os corpos sexuados denominados "femininos"? E mais ainda, pela imbricação deste com os sistemas de dominação de raça e classe, que impõe a mulheres negras e não brancas das classes econômicas mais baixas um atrofiamento das possibilidades de escolha? Como pensar o consentimento em situação de extrema precariedade, como é o caso da grande maioria das meninas e mulheres prostituídas? 
Consideramos, assim como Faria, Coelho e Moreno (2013), que essa posição simplifica o que é a instituição da prostituição e toda a violência que a envolve. Como apontam as autoras:

O principal argumento é que a regulamentação em lei passaria a proteger as mulheres e as livraria da marginalização e estigma, mesmo que os projetos foquem explicitamente na legalização do mercado da prostituição e seus agentes. Existem muitos atores envolvidos nos sistemas de prostituição: clientes, empresários, cafetões e cafetinas, e até Estados. Isso significa que a prostituição não pode ser pensada só a partir de um comportamento individual, mas como uma instituição que está ancorada nas estruturas econômicas e nas mentalidades coletivas. Mas, neste sistema, há um sigilo sobre o papel dos homens, e sobre as prostitutas recai o peso da estigmatização, desprezo e confinamento [...] Isso oculta, principalmente, que a demanda por prostituição é masculina (p. 2).

A reflexão sobre a exploração sexual e, mais especificamente sobre a prostituição, não pode ocorrer sem a compreensão de seu papel estruturante no patriarcado, nas relações econômicas e nas hierarquias entre as mulheres, marcadas na modernidade/colonialidade pela desigualdade racial e pelo racismo.

Não é por acaso que a maior parte das pessoas que estão no mercado da prostituição sejam mulheres não brancas e pobres. Nem que a maior parte dos exploradores e consumidores deste tipo de "serviço" sejam homens - que obtém prazer sexual com pessoas que sabem estar em uma situação explicitamente precária. Pensar e problematizar essas posições é importante para o debate, levando em conta a bilionária quantia de dinheiro que a indústria do sexo movimenta em todo o mundo, atrelando pornografia, prostituição e tráfico de pessoas (FARIA, COELHO \& MORENO, 2013).

Seria mesmo a prostituição, como crescemos ouvindo, a profissão mais antiga do mundo? Ou o correto não seria dizer que é a exploração de pessoas já socialmente oprimidas e precarizadas mais antiga do mundo? Discursos que naturalizam a prostituição impõem uma cortina de fumaça que não nos permite enxergá-la como de fato é: exploração e opressão.

A prostituição é uma construção histórica, que, portanto, vai assumindo diferentes características nos diferentes períodos históricos, assim como nos diferentes lugares. No entanto, é preciso compreender que "desde o início combina aspectos da sexualidade, da família, das relações econômicas e de poder em cada sociedade" (FARIA, COELHO \& MORENO, 2013, p. 3). 
A história do Brasil se inicia marcada pela violação sexual de mulheres, especialmente negras e indígenas, que tiveram seus corpos colonizados também pelo estupro. Como aponta Nunes (2017), no período colonial, foram as mulheres indígenas que inicialmente, além de passar por abusos e estupros, foram submetidas à prostituição pelos seus capturadores. Depois esse espaço foi compartilhado com as mulheres brancas vindas de Portugal, que desfrutavam condições e tratamento diferenciados em função da branquitude, ainda que também sexualmente degradantes. Com a chegada da população africana negra escravizada, suas mulheres foram submetidas a condições de violência e exploração semelhantes às que foram as mulheres indígenas, incluindo a prostituição. De acordo com Nunes:

Com o início da escravidão negra, no Brasil, o cenário da prostituição foi marcadamente alterado pelo fator racial, por meio da exploração dos seus senhores e das suas senhoras era possível encontrar em sua constituição uma significativa quantidade de mulheres negras (CARMO, 2011, p.74). A condição da mulher negra enquanto cativa se desdobrou em uma série de violências que perduram até os dias atuais. Equacionada ao seu corpo, a mulher negra teve em sua sexualidade uma das principais demarcações da sua dimensão identitária (NUNES, 2017, p. 3).

A ideia da prostituição como "a profissão mais antiga do mundo" ou "um trabalho como outro qualquer" naturaliza ainda o modelo de sexualidade masculina que transforma os homens em demandantes de sexo e que justifica a prostituição como uma forma de garantir seu acesso aos corpos das mulheres. Como apontam Faria, Coelho e Moreno (2013), tal naturalização também nos impede de perceber que a prostituição não é apenas troca de sexo por dinheiro, mas uma prática de poder, acessível e regrada, na qual é garantido à classe dos homens o acesso ao corpo das mulheres. Além disso, escamoteia o caráter racista e classista que permeia esse acesso.

Para Faria, Coelho e Moreno, nessa perspectiva, é necessário colocar em questão o "discurso liberal sobre a prostituição, que justifica a banalização da sexualidade e a imposição de novos modelos para a mesma subordinação das mulheres" (p. 3). As autoras enfatizam que considerar a prostituição como exploração nada tem a ver com considerar as mulheres prostituídas como indignas e que, pelo contrário, o feminismo deve incorporar a luta pela superação da estigmatização e marginalização destas mulheres. No entanto, analisam que a 
questão da prostituição não se resume ao grupo de mulheres envolvidas na indústria do sexo, mas diz respeito a todas as mulheres, pois se trata de um fenômeno que legitima e reproduz um modelo patriarcal de sexualidade. Portanto, trata-se de uma luta pela garantia de que todas as mulheres possam viver sem qualquer tipo de violência, "em que o exercício da nossa sexualidade esteja livre do estigma da mercantilização dos nossos corpos e também do cerceamento e moralismo religioso" (p. 19).

Cabe ressaltar ainda que, como apontam os dados da UNICEF (2010 apud RIBEIRO, s/d), aproximadamente 250 mil crianças são exploradas sexualmente no Brasil, sendo a maioria delas meninas das regiões mais pobres (RIBEIRO, s/d). Crianças em situações de extrema pobreza que se tornam presas fáceis do aliciamento de exploradores adultos, majoritariamente homens, que ganham dinheiro oferecendo um "serviço" que atenda a "necessidade" e as fantasias sexuais de outros homens.

Não é coincidência que a maioria dos pedófilos sejam homens e nem que a maioria das vítimas sejam meninas. A cultura patriarcal é a cultura do estupro e da pedofilia. Como aponta Grey (2015), a pedofilia pode parecer tabu, vista com desprezo pela maior parte das pessoas, mas uma análise mais crítica de nossa cultura em geral revela o contrário. Segundo a autora, na realidade, a pedofilia é recompensada e celebrada de modo que toda a nossa cultura e compreensão da sexualidade é construída em torno do que parecem ser desejos pedófilos.

Grey argumenta que isso por ter notado, por exemplo, que uma das categorias mais procuradas nos sites de pornografia é "adolescente" ou "novinha". O conteúdo dos vídeos trazem interpretações de meninas com trajes infantis, muitas vezes colegiais, demonstrando um comportamento "inocente", facilmente manipulável. Ou relações incestuosas entre o "papai" e a "filhinha". O que leva esses telespectadores a preferir esse tipo de conteúdo pornográfico?

Como aponta Grey, a cultura pedófila também pode ser vista na exigência de que mulheres adultas realizem procedimentos estéticos que façam com que elas se pareçam o mais jovem possível - garantindo ainda um lucro extraordinário para a indústria da beleza e também para a indústria farmacêutica, já que a busca pelo ideal (inalcançável) de aparência juvenil eterna e de "beleza" muitas vezes tem 
como resultado uma série de transtornos de saúde. Tudo isso para agradar os homens, que "preferem" mulheres com características físicas mais joviais. A autora conclui que todos os homens que têm esse tipo de "preferência" não são pedófilos pela definição estrita da palavra ${ }^{50}$, no entanto:

[...] parece que um grande número de homens, provavelmente como resultado de profundo condicionamento cultural, encontra muitas das mesmas coisas atraentes em uma mulher que um pedófilo acharia atraente em uma menina. Pequenos lábios, vaginas apertadas, himens intactos, pele macia, membros e vulvas sem pelos, eterna juventude, pequenos corpos frágeis..." (GREY, 2015, s/p, tradução nossa $\left.{ }^{51}\right)$.

O caráter pedófilo do sistema patriarcal em que estamos inseridas/os também se expressa através dos altos índices de casamento infantil. O Brasil ocupa $4^{\circ}$ lugar no ranking mundial dos países com maiores índices desse tipo de casamento, como aponta a pesquisa "Ela vai no meu barco: Casamento na infância e adolescência no Brasil", realizada, entre 2013 e 2015, pela Plan International Brasil e o Instituto Promundo. De acordo com esta mesma pesquisa, somos também o país com maior índice de casamento infantil (que ocorre antes dos 16 anos de idade) na América Latina.

Analisando o contexto dos dois estados brasileiros com as maiores taxas de casamento infantil - Pará e Maranhão - essa pesquisa aponta que são as meninas as mais atingidas, chegando a um total de 65.709 meninas casadas entre 10 e 14 anos de idade e de 488.381 entre 15 e 17 anos. O estudo indica ainda que no país existem cerca de 88 mil meninos e meninas de 10 a 14 anos em uniões “consensuais", civis ou religiosas e que 877 mil mulheres se casaram com até 15 anos.

Como aponta esse estudo, pela legislação vigente, meninas brasileiras podem se casar a partir dos 16 anos com o consentimento dos pais ou de um juiz, exceto em caso de gravidez, quando o limite mínimo de idade deixa de existir. $\mathrm{Ou}$ seja, se uma menina engravida, independentemente da idade, ela pode se casar

\footnotetext{
${ }^{50}$ Segundo o Dicionário Houaiss, a palavra pedofilia (do grego ped(o)- + -filia) significa "perversão que leva um indivíduo adulto a se sentir sexualmente atraído por crianças" ou "prática efetiva de atos sexuais com crianças (p. ex., estimulação genital, carícias sensuais, coito etc.)".

51 "But it seemsthata high numberofmen, likely as a resultofdeep cultural conditioning, findmanyofthesamethingsattractive in a womanthat a pedophilewouldfindattractive in a girlchild. Smalllabia, tight vaginas, intacthymens, baby-soft skin, hairlesslimbsand vulvas, eternal youthfulness, tinyfrailbodies... As tumblruser reddressalertwrote, "how do wenotrecognizethatthisisessentially a descriptionof a baby or a toddler?".
} 
legalmente. De acordo com essa pesquisa, a idade média de casamento e do nascimento do primeiro filho/a das meninas entrevistadas é de 15 anos e os homens são, em média, nove anos mais velhos.

Dentre os principais fatores apontados pelas entrevistadas que levam ao casamento estão:

(1) o desejo, muitas vezes, de um membro da família, em função de uma gravidez indesejada e para proteger a reputação da menina ou da família e para segurar a responsabilidade do homem de "assumir" ou cuidar da menina e do(a) bebê potencial; (2) o desejo de controlar a sexualidade das meninas e limitar comportamentos percebidos como 'de risco' associados à vida de solteira, tais como relações sexuais sem parceiros fixos e exposição à rua; (3) o desejo das meninas e/ou membros da família de ter segurança financeira; (4) uma expressão da agência das meninas e um desejo de saírem da casa de seus pais, pautado em uma expectativa de liberdade, ainda que dentro de um contexto limitado de oportunidades educacionais e laborais, além de experiências de abuso ou controle sobre a mobilidade das meninas em suas famílias de origem; (5) o desejo dos futuros maridos de se casarem com meninas mais jovens (consideradas mais atraentes e de mais fácil controle do que as mulheres adultas) e o seu poder decisório desproporcional em decisões maritais (TAYLOR et al, 2015, p. 11-12).

Os dados levantados por essa pesquisa confirmam que a maioria das uniões envolvendo menores de 18 anos se consolida informalmente e consensualmente. Segundo ela, de modo geral, o casamento é visto pelas meninas e familiares como a principal via de transição para a vida adulta e compreendido como uma opção "menos pior" em relação a educação, percebida como pouco atrativa ou fora do alcance do projeto de vida. É considerado mais seguro cumprir a função supostamente "natural" de mulher, isto é, cuidar dos filhos/as e do lar, enquanto seus maridos cumprem a função de serem os provedores, ainda que muitas vezes também encontrem poucas oportunidades. O casamento com homens já adultos se justificaria, nesta lógica, por estes serem vistos como mais capazes de cumprir a função de provedores. Mas como se constrói essa percepção?

Mais uma vez é necessário colocar em questão o consentimento. Quando o consentimento de menores de idade para casamento se dá em um contexto em que este é visto como uma opção de proteção frente a insegurança econômica e oportunidades limitadas, podemos compreendê-lo como uma escolha individual e deliberada? Será que em outras condições de vida a "escolha" seria a mesma? Como pensar o consentimento de meninas socializadas a partir da 
heterossexualidade compulsória e da cultura do estupro e da pedofilia em um sistema ao mesmo tempo profundamente desigual racial e economicamente?

Em uma sociedade patriarcal, o consentimento é construído dentro dos parâmetros da dominação masculina e, portanto, é um conceito muito vago quando aplicado na prática. As tecnologias de gênero, de que nos fala Lauretis (1994) têm um papel fundamental na construção do consentimento das meninas e mulheres com relações sexuais estabelecidas com homens. Seus dispositivos de poder, como vimos, produzem sentidos e naturalizam a hierarquia sexual nas próprias mulheres, produzindo subjetividades subordinadas. Se há um caminho (im)posto, ensinado desde que nascemos como o destino natural, quais as possibilidades de escolhas e desvios? E ainda, qual é o preço a pagar por tomar uma rota de fuga? Especialmente em contextos social e economicamente precários? Quem pode pagar esse preço?

Uma das principais consequências do casamento na infância e na adolescência é a interrupção momentânea e muitas vezes permanente do processo de escolarização. Esta interrupção encontra-se articulada a outros efeitos desse tipo de contrato precoce: maternidade, limitações impostas pelo marido da mobilidade e da rede social, exposição à violência do parceiro íntimo (muitas vezes bem mais velho).

De acordo com o estudo do Instituto Promundo, nas entrevistas com as meninas casadas é possível notar ainda a oferta inadequada e muitas vezes discriminatória de serviços e de proteção dos seus direitos. Ao que parece, no momento em que casam, as meninas viram propriedade do marido e, portanto, não necessitam mais da proteção especializada que o Estado é obrigado a garantir as crianças e adolescentes.

Esse estudo aponta que muitos profissionais da rede de proteção não percebem o casamento infantil como um "problema". A maior parte dos profissionais entrevistados atribui a "escolha" das meninas pelo casamento ao seu desejo de sair da casa dos pais, poder namorar e ir as festas, isto é, "por causa do "turbilhão" emocional e hormonal sentido durante a adolescência, mas também como uma fuga e como um modo de tolerar as condições difíceis em que vivem" (p. 71). Para eles, a gravidez e o casamento na infância e na adolescência são 
resultado dessas dinâmicas, "sendo assim uma expressão da agência das meninas (ainda que num contexto de oportunidades limitadas)" (idem).

Os profissionais apontam ainda que uma das causas do casamento infantil mais frequentemente é a incapacidade das famílias de proporcionar oportunidades às crianças, devido à fragilidade da estrutura familiar. Na perspectiva deles, tal fragilidade levaria meninas a buscar estabilidade e segurança fora de casa, através do casamento.

É possível notar, a partir dos argumentos apresentados pelos profissionais entrevistados, que suas análises sobre o casamento de meninas se estruturam a partir de uma visão patriarcal colonial: explosões hormonais e emocionais femininas, rebeldia, fragilidade, famílias desestruturadas...

No meu cotidiano de trabalho, bem como na troca de experiências e percepções com colegas de profissão que atuam em outros municípios e estados, percebo que tal visão é compartilhada por grande parte dos profissionais que atuam nos equipamentos que constituem as redes de proteção da infância e da adolescência Brasil a fora. Isso nos leva a analisar que não se trata de uma decisão deliberada, individual de cada um deles, mas de um efeito/finalidade da colonialidade, que constitui as formações profissionais, bem como, as próprias políticas sociais. Com a escola não é diferente.

Dados do PNAD 2013 revelam que cerca de 300 mil brasileiras/os não terminaram o ensino médio, sendo a maior parte deste contingente é de pessoas do sexo feminino. Das adolescentes mães, $55,4 \%$ não chegaram nem a completar o ensino fundamental. Em 2013, no Brasil, das 5,2 milhões de meninas entre 15 a 17 anos, 414.105 tinham pelo menos um filho. Neste grupo, 309.374 estavam fora da escola. De acordo com a pesquisa "As Desigualdades na Escolarização no Brasil”, realizada pelo Ipea, em 2014, entre as meninas de 15 a 17 anos de idade que tinham um filho/a ou mais, apenas $28,5 \%$ frequentavam a escola.

O que esses dados revelam, dentre outras coisas, é o quanto ainda hoje a divisão sexual do trabalho, que relega as mulheres o trabalho doméstico e reprodutivo como função social prioritária, influencia fortemente na interrupção do processo de escolarização básica de meninas. São meninas que deixam a 
escola, como apontado no nosso grupo de discussão pelas estudantes da modalidade EJA, para casarem, terem filhos ou, ainda, para cuidar das crianças pequenas da família durante os períodos de trabalho dos adultos da casa ou de crianças de terceiros em troca de "salários" precários, em contrários informais (e ilegais), pela necessidade de contribuir com a renda familiar.

\subsection{Divisão sexual do trabalho na modernidade/colonialidade e abandono escolar compulsório de meninas}

É na França, no início dos anos 70, que as bases teóricas do conceito de divisão sexual do trabalho se assentam. Quando antropólogas feministas colocam em questão a ideia instituída de que esta noção se referia a complementaridade de tarefas entre homens e mulheres, demonstrando que, na realidade, tratava-se de uma relação de poder entres estes. Neste período, há uma coletivização da tomada de consciência de uma opressão específica, que incide sobre as mulheres, no que diz respeito a fazer parte de uma enorme massa de trabalho invisibilizada, realizada gratuitamente por elas para outrem em nome de uma suposta "natureza", do amor e do dever materno: o trabalho doméstico. Rapidamente, a partir principalmente da conceituação de base marxista, análises desta forma de trabalho começam a ser desenvolvidas.

Feministas começam a colocar em análise o trabalho doméstico partindo da perspectiva de que ele é uma atividade laboral tanto quanto o trabalho profissional. Este pensamento possibilitou considerar ao mesmo tempo as atividades desenvolvidas na esfera doméstica e na esfera profissional e com isso pensar em termos de divisão sexual do trabalho. Como aponta a socióloga feminista francesa Danièle Kergoat (2009), é a partir dessa perspectiva que a divisão sexual do trabalho adquire um valor de conceito analítico.

Para além de pensar uma articulação entre essas duas esferas, o desenvolvimento das análises conceitualizou a relação social recorrente entre a classe sexual dos homens e a das mulheres, que foi denominada pelas francesas como "relações sociais do sexo". Nesta perspectiva, a divisão sexual do trabalho foi definida como "a forma de divisão do trabalho social decorrente das relações 
sociais de sexo" (KERGOAT, 2009 p. 67). Uma forma de divisão historicamente adaptada a cada sociedade que tem dois princípios organizadores: o da separação (destinar prioritariamente os homens à esfera produtiva e as mulheres à esfera reprodutiva) e o da hierarquização (os trabalhos realizados por homens valem mais do que os desempenhados por mulheres). Princípios que, como vimos em capítulo anterior, podem ser aplicados graças a ideologia patriarcal naturalista da "diferença sexual", que através do gênero reduz as práticas sociais a papéis sociais sexuados, como um "destino natural da espécie".

Como apontam Hirata e Kergoat (2007), essa perspectiva impulsionou, e não apenas na França, o desenvolvimento de estudos que utilizaram a abordagem da divisão sexual do trabalho para repensar o trabalho e suas categorias, suas formas históricas e geográficas, a inter-relação de múltiplas divisões do trabalho socialmente produzido. Reflexões que levaram a um questionamento radical da sociologia da família e do paradigma funcionalista que lhe servia de base.

Por uma espécie de efeito boomerang, depois que "a família", na forma de entidade natural, biológica, se esfacelou para ressurgir prioritariamente como lugar de exercício de um trabalho, foi a vez de implodir a esfera do trabalho assalariado, pensado até então apenas em torno do trabalho produtivo e da figura do trabalhador masculino, qualificado, branco (2007, p. 598).

Kergoat (2009) salienta que, em sentido oposto a ideologia naturalista, pensar as práticas sexuadas como resultado de relações sociais, implica análises que considerem que a divisão sexual não é um dado fixo e imutável. Esta perspectiva deve considerar que ainda que os princípios organizadores dessa divisão permaneçam os mesmos, há imensa variação de suas modalidades no tempo e no espaço - concepção de trabalho reprodutivo, lugar das mulheres no trabalho mercantil, etc. Desta maneira, aponta que, na problematização acerca da divisão sexual do trabalho não há determinismo, mas uma análise da dialética entre invariantes e variações. De acordo com a autora, se "supõe trazer à tona os fenômenos da reprodução social, esse raciocínio implica estudar ao mesmo tempo seus deslocamentos e rupturas, bem como a emergência de novas configurações que tendem a questionar a própria existência dessa divisão" (KERGOAT, 2009, p. $68)$.

A filósofa e ativista norte-americana Angela Davis (2016) aponta que no período colonial, nos Estados Unidos, as tarefas domésticas designadas às 
mulheres eram muito diferentes da rotina de trabalho diária designada a "dona de casa" nas sociedades capitalistas avançadas. Se nestas sociedades o trabalho doméstico é orientado pela ideia de servir, que raramente produz algo tangível diminuindo drasticamente o prestígio social das mulheres em geral - no período anterior ele se configurava como uma produção doméstica.

Segundo Davis, no período colonial as mulheres "não eram "faxineiras" ou "administradoras" da casa, e sim trabalhadoras completas e realizadas no interior da economia baseada na casa" (p. 229). Eram elas que produziam a maioria dos artigos utilizados por sua família e também cabia a elas proteger a saúde tanto da família quanto da comunidade.

É com o avanço da industrialização, que transfere a produção econômica da casa para a fábrica, que, de acordo com Davis, a importância do trabalho doméstico das mulheres passa por um desgaste sistemático. Segundo ela, com o avanço da consolidação do capitalismo industrial, vai se tornando mais rigorosa a clivagem entre a nova esfera econômica e a velha economia familiar:

A realocação física da produção econômica provocada pela expansão do sistema fabril foi, sem dúvida, uma transformação drástica. Contudo, ainda mais radical foi a revalorização generalizada da produção necessária ao novo sistema econômico. Enquanto os bens produzidos em casa tinham valor principalmente porque satisfaziam às necessidades básicas da família, a importância das mercadorias produzidas em fábricas residia predominantemente em seu valor de troca - em seu poder de satisfazer as demandas por lucro dos empregadores. Essa revalorização da produção econômica revelou, para além da separação física entre casa e fábrica, uma fundamental separação estrutural entre a economia familiar doméstica e a economia voltada ao lucro do capitalismo. Como as tarefas domésticas não geram lucro, o trabalho doméstico foi naturalmente definido como uma forma inferior de trabalho, em comparação com a atividade assalariada capitalista (DAVIS, 2016, p. 230, grifo da autora).

A socióloga feminista marxista brasileira Heleieth Saffioti (1976), em seus estudos sobre as mulheres na sociedade de classes, traz uma análise que se aproxima do pensamento de Davis, apontando o impacto extremamente negativo trazido pelo capitalismo industrial no trabalho designado às mulheres. De acordo com Saffioti, nas sociedades pré-capitalistas ditas "ocidentais", apesar das mulheres já serem consideradas inferiores aos homens jurídica, social e politicamente, não estavam excluídas do sistema produtivo, desempenhando um relevante papel econômico. Ao mesmo tempo, reconhece que nesta época já havia, na compreensão do seu trabalho como menos importante do que o do 
homem e na localização deste como subsidiário no conjunto das funções econômicas da família, um esboço de sua expulsão do sistema produtivo.

Para Saffioti, o processo de individualização inaugurado pelo modo de produção capitalista impôs às mulheres uma desvantagem social de dupla dimensão. No nível superestrutural, há uma tradicional subvalorização das capacidades femininas, sustentada pelos mitos justificadores da supremacia masculina que organizam as relações sociais. No plano estrutural, à medida que se desenvolviam as forças produtivas, as mulheres vão sendo progressivamente empurradas para a zona periférica do sistema de produção.

Torna-se clara, no novo regime, a divisão da sociedade em classes sociais e a exploração econômica de que é alvo uma delas por parte da outra. O modo capitalista de produção não faz apenas explicitar a natureza dos fatores que promovem a divisão da sociedade em classes sociais. Lança mão da tradição para justificar a marginalização efetiva ou potencial de certos setores da população do sistema produtivo de bens e serviços. Assim é que o sexo, fator de há muito selecionado como fonte de inferiorização social da mulher, passa a interferir, de modo positivo para a atualização da sociedade competitiva, na constituição das classes sociais (SAFFIOTI, 1976, p. 35)

Para Saffioti, compreender a marginalização do trabalho feminino diz respeito a compreender a marginalização da própria mulher enquanto socius. Assim, considera que, na análise do processo de assalariamento do qual participam homens e mulheres, é preciso verificar o modo específico em que este se desenvolve para representantes de um e de outro sexo. Não apenas no que diz respeito às contradições nele expressas, como ainda na "intensificação dessas contradições no trabalho feminino e suas repercussões nas diferentes subestruturas da sociedade" (p. 38).

Federici (2019) desenvolve suas análises sobre o trabalho doméstico na sociedade de classes ressaltando a necessidade de reconhecer que este trabalho não é um trabalho como os outros. Para a autora, é certo que sob o capitalismo, todo trabalhador é manipulado e explorado, sendo sua relação com o capital completamente mistificada. Nesta relação, o salário dá a impressão de uma troca justa em que trabalhamos e somos pagos por isso, de modo que trabalhador e patrão recebem o que lhes é devido. Mas na realidade, o salário, em vez de ser o pagamento pelo trabalho realizado, oculta todo o trabalho não pago que gera o lucro para o empregador. 
Federici argumenta, no entanto, que ainda assim o salário é uma forma de reconhecimento do trabalhador, que o possibilita reinvindicar os termos e quantidades desse pagamento. Receber um salário significa fazer parte de um contrato social, o que institui um significado a respeito do trabalho desempenhado que não deixa dúvidas sobre razão de seu exercício: trata-se de uma condição sob a qual, no sistema capitalista, se está autorizado a viver e não de um desejo natural, inerente a existência do ser. Assim, ainda que explorado de muitas maneiras, o trabalhador assalariado não é o seu trabalho.

De acordo com Federici, a principal diferença do trabalho doméstico em relação aos outros trabalhos é que ele foi imposto às mulheres como um atributo natural da psique e personalidade feminina, uma característica intrínseca ao seu sexo, o que justificou sua não remuneração. Convencer que o trabalho doméstico é para as mulheres uma atividade natural, inexorável e desejada, foi uma estratégia do capital para que aceitássemos trabalhar sem remuneração. E ao mesmo tempo, a condição de não remuneração deste trabalho transformou-se em uma ferramenta poderosa na disseminação e fortalecimento da concepção do trabalho doméstico como um não trabalho, dificultando a própria luta das mulheres contra ele. Para a autora, ao transformar o trabalho doméstico em um "ato de amor" que, portanto, não carece remuneração, o capital teve dois ganhos fundamentais:

Primeiramente, ele obteve uma enorme quantidade de trabalho quase de graça e assegurou-se de que as mulheres, longe de lutar contra essa situação, procurariam esse trabalho como se fosse a melhor coisa da vida (as palavras mágicas: "sim, querida, você é uma mulher de verdade"). Ao mesmo tempo, o capital também disciplinou o homem trabalhador, ao tornar "sua" mulher dependente de seu trabalho e de seu salário, e o aprisionou nessa disciplina, dando-lhe uma criada, depois de ele próprio trabalhar bastante na fábrica ou no escritório. De fato, nosso papel como mulher é sermos servas felizes e sobretudo amorosas da "classe trabalhadora", isto é, daqueles estratos do proletariado aos quais o capital foi obrigado a conceder mais poder social. Tal como Deus criou Eva para dar prazer a Adão, assim fez o capital criando a dona de casa para servir física, emocional e sexualmente o trabalhador do sexo masculino, para criar seus filhos, remendar suas meias, cuidar de seu ego quando ele estiver destruído por causa do trabalho e das (solitárias) relações que o capital reservou (2019, p. 44).

Davis (2016) considera a "dona de casa" como um subproduto ideológico produzido na transformação econômica trazida pelo capitalismo industrial. Segundo ela, as "mulheres começaram a ser redefinidas ideologicamente como as guardiãs de uma desvalorizada vida doméstica” (p. 230). No entanto, a autora 
ressalta a contradição desta redefinição do lugar da mulher com o grande número de mulheres brancas imigrantes no nordeste dos Estados Unidos, bem como com as milhares de mulheres negras que trabalhavam fora de casa como produtoras forçadas da economia escravagista do Sul. De acordo com ela, no século XIX, a realidade do lugar da mulher na sociedade estadunidense "envolvia as mulheres brancas, cujos dias eram gastos na operação das máquinas das fábricas em troca de salários extremamente baixos, assim como certamente envolvia as mulheres negras, que trabalhavam sob coerção da escravidão" (DAVIS, 2016, p. 231). Deste modo, a "dona de casa" refletia uma realidade parcial, que, em certa medida, era vista como "um símbolo da prosperidade econômica de que gozavam as classes médias emergentes" (idem).

Davis aponta que "devido à intrusão adicional do racismo, um vasto número de mulheres negras teve de cumprir as tarefas de sua própria casa e também os afazeres domésticos de outras mulheres" (2016, p. 239). Frequentemente as exigências do emprego na casa da mulher branca obrigavam a trabalhadora doméstica negra a negligenciar seus próprios filhos.

De acordo com Davis, ao longo da história dos Estados Unidos, a maior parte das mulheres negras trabalhava fora de casa. O trabalho doméstico nunca foi para as mulheres negras, tanto "livres" quanto escravizadas, foco central de suas vidas. Assim,

Elas escaparam, em grande medida, ao dano psicológico que o capitalismo industrial impôs às donas de casa brancas de classe média, cujas supostas virtudes eram a fraqueza feminina e a submissão de esposa. As mulheres negras dificilmente poderiam lutar por fraqueza; elas tiveram que se tornar fortes, porque sua família e sua comunidade precisavam de sua força para sobreviver (p. 232).

Davis continua, apontando que:

As qualidades femininas não ortodoxas da assertividade e da independência pelas quais as mulheres negras têm sido frequentemente elogiadas, mas mais comumente censuradas - são reflexos de seu trabalho e de suas batalhas fora de casa. No entanto, da mesma maneira que suas irmãs brancas chamadas de "donas de casa", elas cozinharam e limparam, além de alimentar e educar incontáveis crianças. E, ao contrário das donas de casa brancas, que aprenderam a se apoiar no marido para ter segurança econômica, as esposas e mães negras, geralmente também trabalhadoras, raramente puderam dispor de tempo e energia para se tornar especialistas na vida doméstica. Como suas irmãs brancas da classe trabalhadora, que também carregam o fardo duplo de trabalhar para sobreviver e 
de servir a seu marido e a suas crianças, as mulheres negras há muito, muito tempo precisam ser aliviadas dessa situação opressiva (DAVIS, 2016, p. 233).

hooks (2010), no sensível texto "Vivendo de Amor", fala que a necessidade de permanecerem fortes para sobreviver impôs outros danos psicológicos à população negra em geral e as mulheres negras em particular. De acordo com a autora, a marca da violência fundante da escravidão, do trabalho forçado e excessivo, bem como a perpetuação do racismo e da supremacia dos brancos após a abolição, impôs aos negros a manutenção de certas barreiras emocionais.

Compreendendo o amor como uma experiência profundamente política, hooks aponta que a possibilidade de sobrevivência no contexto da escravidão era muitas vezes determinada pela capacidade dos/as negros/as de conter e reprimir suas emoções. De acordo com ela, as condições terríveis de vida da escravidão impossibilitavam que entendessem "essa coisa que a gente chama de amor" (2010). Isto porque, sua noção de intimidade se constituiu ligada ao sentido prático de sua realidade.

A escravidão condicionou os negros a conter e reprimir muitos de seus sentimentos. $\mathrm{O}$ fato de terem testemunhado o abuso diário de seus companheiros - o trabalho pesado, as punições cruéis, a fome - fez com que se mostrassem solidários entre eles somente em situações de extrema necessidade. E tinham boas razões para imaginar que, caso contrário, seriam punidos. Somente em espaços de resistência cultivados com muito cuidado, podiam expressar emoções reprimidas. Então, aprenderam a seguir seus impulsos somente em situações de grande necessidade e esperar por um momento "seguro" quando seria possível expressar seus sentimentos (HOOKS, 2010).

Para hooks, a ideia de que o amor compromete a sobrevivência vem sendo passada de geração em geração, fazendo com que muitos creiam que a habilidade de conter as emoções é uma característica positiva, um sinal de personalidade forte. No que tange às mulheres negras, em especial, isto se revela na prática comum de se enfatizar sua capacidade de persistir e sobreviver em circunstâncias difíceis - a imagem da mulher "guerreira".

No entanto, hooks enfatiza a necessidade de ir além da sobrevivência. Ela aponta que é preciso criar condições para viver plenamente e para tanto, as mulheres negras não podem mais negar sua necessidade de amar. "A partir do momento que acreditarmos, de preferência desde crianças, que nossa saúde 
emocional é importante, poderemos suprir nossas outras necessidades (HOOKS, 2010).

Mas o amor a que hooks se refere não é o amor da ideologia burguesa patriarcal, baseado na heterossexualidade compulsória, orientada para a procriação, e a subserviência e dedicação integral das mulheres aos homens e à prole proveniente das relações conjugais monogâmicas e aos cuidados do lar. O amor em culturas patriarcais está ligado a paradigmas de dominação e submissão, em que o pressuposto dos laços amorosos heterossexuais se funda na ideia de que as mulheres, "naturalmente" em contato com os sentimentos de cuidado, dão amor aos homens, e estes, "naturalmente" em contato com poder e agressão, por recompensa, provêm e protegem. Mas em uma relação de dominação, a promessa de "proteção" é, na verdade, o estabelecimento de um poder tirano por parte de quem domina, isto é, o poder masculino é utilizado injustamente para coagir e controlar (HOOKS, 2019).

Em uma perspectiva feminista, hooks (2019) fala de outro amor. De um amor que só existe se não há dominação e coerção. Um amor fundamentado em reconhecimento e aceitação, que combina cuidado, responsabilidade, comprometimento e conhecimento, e que não pode existir sem justiça. De acordo a autora, com essa consciência do amor, que para ela é possível através do feminismo, "vem a compreensão de que o amor tem o poder de nos transformar e nos dar força para que possamos nos opor à dominação" (HOOKS, 2019, p. 150).

No entanto, o que observamos na sociedade moderna/colonial, nas suas instituições em geral e nas instituições escolares e abordagens educacionais e pedagógicas em particular, é que a compreensão de amor e cuidado ainda se baseia na concepção patriarcal colonial. O modelo normativo das relações é um modelo sexista-racista-classista.

Nesse contexto, são muito frequentes nas queixas escolares encaminhadas à Psicologia os discursos que atribuem as dificuldades apresentadas por estudantes a falta de "carinho", "preocupação" e "atenção" que recebem de suas famílias e, mais especificamente, das suas mães. "A mãe não está nem aí pro/a filho/a", "a mãe nunca vem na reunião", "a mãe inventa que não tem tempo pra vir na escola", "a mãe não dá carinho", "a família não tá nem aí pra esses filhos, vivem todos 
largados". Frases deste tipo são absolutamente comuns na construção das hipóteses trazidas pelas equipes como explicações para condutas consideradas ruins, apresentadas por estudantes.

De fato, em alguns dos casos, é possível notar certo distanciamento, pouco contato e diálogo entre estudantes e seus familiares. Mas o olhar lançado pela escola raramente considera esse modo de estabelecer relações como uma produção social e histórica, adotando quase sempre uma perspectiva que meramente culpabiliza os familiares em geral, e as mães, em particular, colocando-as como deliberadamente desleixadas, frias e desumanas. Afinal, "como pode colocar um filho no mundo e não estar nem aí pra ele? Ainda mais a mãe!” (sic). Muito menos a escola problematiza o modelo de afetividade que temos como referência para analisar as relações e as condições em que ele se desenvolve.

Cabe ressaltar, que não estamos aqui negando que famílias possam estabelecer dinâmicas violentas. Sabemos que isso é possível e acontece, como mostram os altos índices de violência doméstica e abusos perpetrados por familiares em todas as camadas sociais. No entanto, certamente, esse não é o caso da maioria das famílias com as quais lidamos na escola. Muitas vezes é o olhar das equipes pedagógicas e técnicas, guiado pelo modelo de família nuclear (a "família estruturada"), que imediatamente as fixa em um lugar de inexorável de falta e violência, impossibilitando qualquer troca que possa contribuir de fato para o estabelecimento de vínculos familiares mais potentes nos casos em que eles se encontram fragilizados. E mesmo dificultando atuar efetivamente nos casos em que de fato há violências e violações.

O modelo de "família estruturada" se funda no sexismo, na heterossexualidade compulsória, no racismo e na exploração de classe. Nesta perspectiva, uma família só pode ser saudável se ela corresponde ao modelo patriarcal burguês branco de relações sexuais e afetivas - que fixa a posição hierárquica de autoridade no pai sobre a mãe e os/as filhos/as submissos e coloca como responsabilidade principal (se não exclusiva) da mãe os cuidados com os/as filhos/as. Do contrário, produzirá necessariamente sujeitos desviantes, inclinados à marginalidade. 
Esse pensamento ganha força e materialidade no Brasil nas políticas higienistas adotadas a partir do final do século XIX (COIMBRA, 2000). Aliandose à Teoria da Degenerescência de Morel (1957 apud COIMBRA, 2000), o higienismo afirmava que as pessoas nascidas em terreno propício para "boas sementes", ou seja, em "bons lares", teriam naturalmente virtudes, enquanto que aquelas nascidas e criadas em "lares indignos", isto é, pobres, precárias, seriam portadores de "má herança" e, portanto, degeneradas.

A teoria geral da degenerescência, apoiada e reproduzida principalmente por psiquiatras da elite brasileira, serviu por quase meio século de quadro teórico e de justificação social e moral de todas as técnicas de intervenção e identificação dos ditos "anormais" (FOUCAULT, 1997). Essas ideias se aliavam às teorias racistas que explicavam que doenças, tanto físicas quanto morais, que estariam nas origens dos perigos sociais, eram atributos das raças consideradas inferiores (negras e indígenas). Como apontam Soares e Zamora (2019), "no início do século XX, a relação estabelecida entre uma ciência racista e o conceito de degenerescência é aliada na construção de um Estado racista e controlador, devido ao seu alto e perigoso índice de miscigenação" (p. 273).

Sob a justificativa de defesa da sociedade, logo começam a ser adotadas diversas medidas relacionadas à pobreza, todas embasadas nos preceitos higienistas e racistas. Os pobres, em sua maioria não brancos, passam então a ser classificados moralmente como "dignos" ou "viciosos" (RIZZINI, 1997 apud COIMBRA, 2000), particularizando para cada categoria medidas específicas. Adota-se um modo de assistir essas pessoas que se dá nas condições de observar/vigiar se a falta de meios de subsistência é "legítima" ou se sua pobreza e/ou doença está ligadas a razões moralmente questionáveis, como devassidão, indolência e vícios, associados também a sua "raça".

O plano de ordem social passa a ser o da assistência e vigilância daqueles que não possuíam meios de subsistência. Por um lado, os pobres viciosos, aqueles que viviam no ócio - uma das características mais indesejáveis no sistema capitalista -, são considerados criminosos em potencial e devem ser corrigidos, pois representam um "perigo social" a ser extinto. Por outro, os pobres dignos, aqueles que trabalham e mantém a família sob os costumes religiosos (cristãos), 
pertencentes a uma classe que necessita consolidar os valores morais - uma vez que têm uma tendência natural aos vícios e às doenças. A educação é uma instituição fundamental neste processo.

Nessa perspectiva, afirma-se ainda mais certo modo de viver universal e natural, onde a família estruturada é aquela composta pelo casal heterossexual e monogâmico, ligado por um determinado tipo de amor também universalizado. Na relação com os filhos fica estabelecido que os pais e, particularmente as mães, têm o dever de educar, alimentar, cuidar, abrigar e vigiar os filhos, enquanto que aos filhos cabe obedecer, conter a própria sexualidade e triunfar na escola (NASCIMENTO, 2005). Tudo que escape a esse modelo de existência passa a ser então desqualificado, colocado em situação de falta, de ameaça, de perigo e a necessitar, portanto, uma vigilância constante e uma correção eficaz.

Como vimos anteriormente, a Psicologia tem uma função importante na construção desse pensamento. Ela foi um saber fundamental para construir as bases científicas das teorias que legitimam o modelo familiar patriarcal burguês branco como o modelo "ideal" de família, caracterizando com seus termos técnicos (e colonizados) os "desviantes", que devem receber intervenções médicas e sociais corretivas e disciplinadoras, em nome do "cuidado".

No que diz respeito ao sexismo, como aponta Lerner (2019), a psicologia moderna "observou as diferenças sexuais existentes segundo a suposição não questionada de que eram naturais e, assim, forjou uma mulher psicológica tão determinada pela biologia quanto suas antepassadas" (p. 45). Sem considerar a história, muitos psicólogos e psicanalistas observaram os papéis sexuais chegando a conclusões com base no estudo de dados clínicos que reforçavam o caráter natural desses papéis. Tais interpretações deram renovado prestígio ao antigo argumento de que o papel principal das mulheres é ter e cuidar de crianças.

Como visto anteriormente, a educação assume um papel importante no enquadramento dos sujeitos aos modos de vida dominantes. Ainda que, ao longo da história, reconheçamos nas instituições educacionais a presença de forças instituintes (BAREMBLITT, 2002), isto é, questionadoras do que está instituído, insurgentes, que buscam transformação, como vimos, na base de sua criação está a função de adestrar a população à lógica instituída. A escola assume assim o 
papel de, por via de mecanismos pedagógicos/disciplinares, ensinar as crianças e adolescentes e, em certa medida, as famílias, especialmente das classes subalternizadas, a pensar, sentir e viver dentro do modelo normativo estabelecido: branco e burguês.

Para as meninas isso significa um enquadramento no modelo patriarcal branco burguês de mulher. É preciso ensiná-las desde pequenas a terem "bons modos", serem cuidadosas, complacentes, submissas e disponíveis aos homens. Através de mecanismos pedagógicos/disciplinares, a escola reforça e reproduz a socialização sexista, naturalizando assim a submissão das meninas ao poder patriarcal-colonial.

Quando o discurso pedagógico é insuficiente para o enquadramento desejado, muitas vezes recorre-se às outras instituições. As ameaças de intervenções do "Conselho Tutelar" ou do "Comissariado da Infância e Juventude" (sic) - compreendidos pelo imaginário social e frequentemente apresentados para as/os estudantes e suas famílias como órgãos punitivos, ainda que esta não seja oficialmente sua função - são um exemplo disso. Não raro, as "conversas" com as estudantes, assim como com suas mães e familiares, partem do discurso que "informa" os problemas jurídicos e a possibilidade de perderem seus direitos, inclusive de ficar com as/os filhos, caso não se enquadrem.

Baseadas nesse tipo de "informação", as intervenções das equipes escolares se distanciam de abordagens de acolhimento, cuidado e responsabilização - ainda que em teoria se coloquem como tal - transformando-se em mais uma engrenagem de controle e manutenção da regulação patriarcalcolonial da vida e, consequentemente, da reprodução da sociedade. Essa é uma das maneiras pelas quais as instituições educacionais atualizam a função social que as funda no sistema capitalista moderno/colonial: reguladoras e mantenedoras das estruturas de dominação.

Quando nem as ameaças e punições disciplinares são capazes de promover o enquadramento desejado, a exclusão/marginalização se torna então a medida a ser adotada. Por meio de intervenções constrangedoras, suspensões, "convites" para se retirar da escola ou, simples e principalmente, pela omissão/indiferença, a escola vai informando quem não a serve mais. 
Ouvi algumas vezes de membros das equipes escolares suspiros de alívios e até mesmo a frase "menos um!", quando um/a estudante visto como "problemático" desaparecia da escola. Nas ocasiões em que isso aconteceu, expressei meu espanto e estranhamento diante de tais reações. Mas raramente senti sinais de constrangimento por parte dos/as que o fizeram. Outra pergunta que pode então ser colocada é: como permanecer em um lugar onde você é apenas mais (ou menos) um/a?

Dentre as situações em que na prática observei os modos como a exclusão/marginalização escolar opera, uma em especial me vem a memória. Foi quando recebi de uma estudante a informação de que duas de suas colegas de classe, ambas negras e pertencentes a uma comunidade altamente estigmatizada, estariam em situação grave de vulnerabilidade. Tais estudantes vinham faltando muito as aulas.

Eu trabalhava nessa escola uma vez por semana. Após receber a informação, por três semanas seguidas, fui até a sala das estudantes, chamá-las para uma conversa. Todas as vezes elas se negaram a conversar comigo, de modo veemente. Diziam: “lá vem ela de novo!”, “que saco!", “sai daqui, eu não vou falar com você!” (sic). Na terceira vez, me dirigi a uma coordenadora pedagógica, mulher branca, para conversar sobre a situação e pedir que ela ou alguma outra colega conversasse ao longo da semana com as estudantes, no sentido de desmistificar a minha função na escola. Isto porque, frequentemente, ouvia das/os estudantes relatos de que elas/es tinham vergonha de me procurar. Havia uma ideia de que "só precisa de psicólogo quem tá louco" (sic.), o que gerava piadas constrangedoras entre seus pares.

Quando, na semana seguinte, perguntei à coordenadora se ela havia conseguido conversar com as meninas, ela respondeu negativamente. Emendou sua fala com o comentário de que a escola havia estado "muito agitada" naquela semana.

De fato, a escola em que trabalhávamos era grande, tinha muitos estudantes e uma rotina muito agitada, normalmente. Eu sabia disso, assim como sei que as condições de trabalho são muitas vezes precárias, com poucos recursos materiais e humanos, o que, certamente, dificulta contatos mais profundos com 
as/os estudantes. Por isso mesmo, tentei esclarecer se ela havia tentado falar com as estudantes e elas tinham novamente se recusado ou se não havia conseguido nem tentar o contato. Ela disse apenas que era muito difícil acessar aquelas meninas, pois elas tinham comportamentos muito "arredios" e "agressivos", que alias "eram muito comuns em pessoas da comunidade delas (sic.)".

Tal colocação me deu a dimensão do que estava em jogo. A coordenadora não havia sequer procurado as meninas, apesar da gravidade dos casos, pois para ela, eram "um caso perdido". Diante disso, entendi que a abordagem da coordenação poderia trazer mais prejuízos do que benefícios para a construção de uma relação de confiança, capaz de fazer as estudantes se sentirem seguras para conversar.

A situação me deixava, a cada dia, mais apreensiva. Eu não queria impor o contato, mas precisava conversar com elas e saber melhor o que estava acontecendo. Neste processo, me aprofundando nos estudos e escutas das vozes que até então desconhecia ou conheci muito pouco durante minha formação, comecei a colocar em questão o que eu representava para aquelas estudantes. Uma psicóloga branca, agente da instituição que as rotula sistematicamente como "difíceis, arredias e agressivas". Que mensagem meu corpo branco "institucional" passava? Estavam elas sendo deliberadamente "arredias" ou, ao contrário, em certa medida, sendo autoprotetivas e resistentes às abordagens educacionais violentas e normatizadoras que minha branca figura, a princípio, representava? Em uma instituição fundada pelo racismo, o sexismo e a exploração de classe articulados, que tende a patologizar e normatizar os corpos "desviantes" de seus "modelos-padrão", o que esperar de seus agentes - em especial da área que "só vai quem é louco" (sic)?

A partir desses questionamentos, busquei caminhos para desconstruir essa primeira imagem, considerando que era minha a responsabilidade de fazer esse movimento. A conversa aconteceu algumas semanas depois que eu fiz contato com uma das líderes da comunidade à qual pertenciam as estudantes e com ela estabeleci uma colaboração que, com o tempo, possibilitou às estudantes se sentirem seguras para conversar. 
As situações tinham também relação com violência masculina e necessitavam uma articulação complexa com outros equipamentos da rede de proteção da infância e adolescência. Mas esse trabalho foi feito sem auxílio ou interesse de membros/as da equipe escolar que deveriam estar implicados na questão. Não pude deixar de notar que, em casos semelhantes, mas com estudantes brancas, o desinteresse completo não havia acontecido. Nestes, ainda que a mobilização da equipe tenha sido pouca, um interesse em ao menos saber o andamento das articulações com a rede foi manifestado.

O pacto narcísico da branquitude, de que fala Bento (2014), se evidencia nesse tipo de movimento (ou estagnação).O movimento de autoproteção do grupo branco e a negação de qualquer identificação com a negritude dificultame, por vezes, impossibilitam o acolhimento de estudantes negras/os.No caso das mulheres, em específico, levando em conta a ordem patriarcal em que estamos todas inseridas, sabemos que nós, em menor ou maior grau, com maior ou menor consciência, somos todas por ela violentadas em diversas dimensões, ao longo da vida. Muitas vezes naturalizamos essas violências, justamente por sermos socializadas nesta lógica. No entanto, percebia que em grande parte das situações em que agentes educacionaisbrancas desnaturalizavam o sexismo e, em alguma medida, conseguiam se identificar como classe sexual oprimidacom as estudantes que sofriam tais violências, se colocando mais disponíveis para acolhê-las e atuar protetivamente, isso acontecia se havia também a identificação racial.

Ao perceber o movimento das minhas colegas, me perguntei se eu mesma já não havia da mesma maneira. Não soube responder categoricamente. Mas pensei que, provavelmente, sim. A branquitude é tão invisibilizada pelas/os brancas/os, e o racismo e seus efeitos nas relações tão naturalizado, que podemos afirmar que é impossível que uma pessoa branca, ainda que sensível aos efeitos cruéis das desigualdades sociais, não tenha firmado esse pacto em nenhum momento ao longo da vida. E mesmo quando passamos a analisar criticamente a branquitude e o racismo que ela produz e pratica,isso não nos coloca em uma posição antirracista imediata e permanente. $\mathrm{O}$ racismo é estrutural e estruturante da nossa sociedade e, deste modo, conscientemente ou não, criticamente ou não, pessoas brancas usufruem dos privilégios que ele as concede socialmente. Diante disto, é preciso assumir o compromisso ético de desnaturalizare 
combatercotidianamente lógicas de dominação dentro e fora de nós. Nenhuma justificativa para o racismo pode ser sustentada.

Como vimos, o racismo coloca os corpos-vidas negros em posição de desumanidade (colonialidade do ser). Nesta perspectiva, a imbricação sexismoracismo que constitui o modelo de feminilidade instituído como "normal" faz com que as práticas de enquadramento assumam especificidades quando voltadas aos corpos-vidas dessas meninas. A desumanização racista atrelada ao sexismo justifica não apenas uma necessidade permanente de controle e vigilância dos comportamentos e capacidades sexuais e reprodutivas das meninas e mulheres, visando garantir que elas permaneçam em posições de subordinação aos homens, mas ao mesmo tempo mecanismos de controle de seus corpos-vidas que garantam a subordinação ao grupo branco como um todo e aos homens brancos em especial. É preciso garantir que meninas e mulheres negras e não brancas continuem a ser educadas para servir a sociedade branca-patriarcal.

Consideramos que, atendendo a essa lógica, o casamento com um homem e a maternidade aparecem nos discursos educacionais como instituições capazes de colocar meninas em seus "devidos lugares". Naturalizando o sexismo e assumindo modelos patriarcais coloniais, velada ou diretamente, afirma-se que o casamento e a maternidade, mesmo precoces, podem constituir caminhos para uma possível "salvação". Eles representariam, especialmente para as meninas que apresentam posicionamentos críticos, desafiadores e, principalmente, considerados sexualmente "desviantes", uma chance de retirá-las do "mau caminho", isto é, do caminho que foge ao controle e ameaça a ordem.

Observamos que esse tipo de abordagem contribui significativamente para o abandono escolar das meninas. Ao colocarem o casamento e a maternidade ainda na adolescência como alternativas adequadas para elas, reforçam a perspectiva patriarcal da divisão sexual do trabalho, que coloca a função primeira (e natural) do sexo denominado feminino como a de reproduzir, cuidar e servir os homens, o sexo masculino. E, ao mesmo tempo, contribuem para que as meninas tenham menos possibilidades de trilhar caminhos emancipatórios em diversos aspectos. Limitadas por contratos matrimoniais patriarcais e/ou fixadas a função "natural" de procriar e cuidar (das crianças, do marido, do lar), sem completar o 
processo educacional escolar, contando muitas vezes com poucos recursos econômicos e/ou criando sozinhas suas crianças (não esqueçamos o alto índice de abandono paterno em nosso país), e, desta maneira, muitas vezes tendo que se sujeitar a trabalhos mal pagos e/ou sem garantias trabalhistas básicas, dificilmente conseguem ter condições para aprofundar e realizar seus próprios desejos. Ficam assim mais vulneráveis a exploração.A escolarização assume uma posição secundária, menos importante e que, pode ser descartada, em nome da preservação da primeira.

Ao mesmo tempo, quando as meninas abandonam a escola para se dedicar ao casamento ou à maternidade, são individualmente responsabilizadas por essa "escolha", sem que a instituição coloque em questão seu papel e o papel da sociedade como um todo nesse processo, nem ofereça subsídios para que a escolarização não seja interrompida. Não tardam a surgir comentários (via de regra, fundamentados em perspectivas racistas e classistas) acerca da irresponsabilidade pela gravidez precoce da menina ou da irresponsabilidade dos familiares que permitiram o casamento. Ainda assim, "a maternidade pode ajudála a tomar juízo", "quem sabe o casamento dê uma 'segurada nela', fazendo ela deixar de ser tão sexual". Um ciclo de abordagens violentas do qual é difícil escapar, visto que qualquer passo pode ser (e será) interpretado como desvio. Como uma dívida que jamais se paga.

Como falar em abandono escolar como uma escolha meramente individual, sem analisar esse tipo de abordagem e os complexos e controversos jogos de poder que as constituem? É nesse sentido que acrescentamos o termo compulsório para falar do abandono escolar. Para romper com a visão individualizante sobre ele e explicitar seu caráter político e estrutural.

Os depoimentos das estudantes do EJA são reveladores. Quando contam que, ao deixarem de frequentar a escola na "idade certa" - majoritariamente por razões que envolviam casamento infantil, maternidade e trabalho doméstico praticamente nenhuma delas foi procurada por nenhum/a dos/as membros/as das equipes escolares sobre o afastamento, estas estudantes nos levam a questionar quem, na verdade, abandona quem. 
Ouvindo as estudantes, é possível perceber que muitas vezes elas deixam de frequentar a escola por não sustentarem ou mesmo recusarem os discursos e práticas normativas e moralizantes acerca de suas vidas e condutas - como uma forma de resistir a essa dominação.Discursos e práticas que operam sem abrir qualquer brecha para uma escuta atenta das suas demandas e que, desta maneira, nada tem a oferecer de fato em termos de promoção de autonomia, emancipação e/ou superação de situações difíceis. O espaço para discussões e orientações importantes sobre sexualidade, direitos, consentimento, dentre outros, é muito reduzido.Esse silenciamento serve a manutenção de posições subordinadas a ordem colonial patriarcal instituída.

Além disso, em termos práticos, sabemos que meninas abandonam a escola quando, por exemplo, ao se tornarem mães a maior parte das estudantes não têm com quem deixar suas crianças para frequentarem as aulas. Não há políticas que de fato deem conta dessa demanda e isso não é por acaso. A lógica de que existe um trabalho prioritário das mulheres, que é de responsabilidade exclusiva delas e deve ser cumprido custe o que custar, faz com a socialização/coletivização do trabalho doméstico e reprodutivo, de que trata Davis (2016), não seja considerada uma pauta fundamental a ser discutida, reinvindicada e implementada. Como aponta a autora:

Hoje, para mulheres negras e para todas as suas irmãs da classe trabalhadora, a noção de que o fardo das tarefas domésticas e do cuidado com as crianças pode ser tirado de seus ombros e dividido com a sociedade contém um dos segredos radicais da libertação feminina (DAVIS, 2016, pp. 233-234).

Deixar que estudantes desapareçam em silêncio, anônimas, é abandono. E poderíamos pensar tal abandono como próximo à face cruel da biopolítica, que abandona a própria sorte, que deixa morrer aqueles/as que considera como ingovernáveis e/ou inúteis e que, portanto, representam perigo à ordem social instituída. 


\section{CONSIDERAÇÕES FINAIS}

A partir de uma perspectiva feminista e decolonial, buscamos deflagrar as persistências da lógica colonial na atualidade e seus efeitos na vida de meninas e mulheres, em especial no que diz respeito ao processo de escolarização. A partir dessa análise, pudemos notar que a produção do fracasso e/ou do abandono escolar de meninas, assim como de meninos, da rede pública de ensino, tem forte relação com as desigualdade econômicas e raciais que estruturam nossa sociedade e suas instituições.

No entanto, percebemos ainda que, no caso das meninas, por terem historicamente, pela ordem patriarcal, suas capacidades reprodutivas e sexuais como alvo de controle e exploração (LERNER, 2019, FEDERICI, 2017), seu afastamento da escola apresenta razões peculiares. Observamos que elas frequentemente se relacionam com divisão sexual do trabalho, que coloca o trabalho reprodutivo e o trabalho doméstico como funções naturais e prioritárias do denominado "sexo feminino", posicionando outras atividades em lugar secundário de importância na vida de meninas e mulheres.

No sistema capitalista moderno/colonial, no entanto, não é possível analisar a divisão sexual do trabalho fora da imbricação dos sistemas de dominação raça, gênero e classe. Por isso, neste estudo, buscamos compreender como cada um desses sistemas opera e o que produzem quando imbricados, especialmente sobre os corpos-vidas das mulheres.

Vimos que, na colonialidade, atrelada ao racismo e à exploração de classe, a ordem patriarcal posiciona hierarquicamente suas subordinadas de acordo com o grupo racial e econômico ao qual pertencem, incidindo sobre cada um deles de maneira qualitativamente diferente. No caso das mulheres pertencentes aos grupos raciais inferiorizados, especialmente das classes econômicas mais baixas, isso implica uma radicalização da posição de subalternidade e das políticas de controle voltadas a seus corpos-vidas. A própria divisão sexual do trabalho imbricada ao racismo e a exploração de classe faz com que essas mulheres, como colocado por Davis (2016), carreguem o duplo fardo de trabalhar para sobreviver - servindo as classes dominantes, muitas vezes em condições precárias - e de servir a seu marido e a suas crianças. 
Operando a partir da lógica colonial, a educação desempenha, ao longo da história, um papel de enquadramento de crianças, adolescentes e famílias nos modos de vida dominantes, como uma forma de garantir a manutenção do status quo. Observamos que com as estudantes, existe uma especificidade desta lógica que se dá no sentido de um adestramento à feminilidade, que combina sexismo, racismo e classismo, incidindo de modo especificamente violento sobre os corposvidas não brancos. O caráter desumanizador do racismo, atrelado a exploração de classe, justifica a imposição de mecanismos de vigilância e correção mais intensos sobre os corpos-vidas negros e não brancos, pois há como objetivo não apenas a subordinação sexual, mas racial e de classe. Isto é, para a ordem instituída, meninas pertencentes aos grupos raciais e econômicos subalternizados devem ser ensinadas não apenas a servir aos homens, mas ao grupo racial e econômico dominante: branco burguês.

$\mathrm{Na}$ perspectiva do adestramento/enquadramento das estudantes, notamos que a ideia de que o casamento heterossexual (geralmente com homens mais velhos) e a maternidade são instituições "protetivas" para as meninas é, velada ou declaradamente, reforçada nas práticas educacionais. Esta abordagem contribui significativamente para o abandono escolar das meninas, uma vez que legitima a perspectiva patriarcal de que a função primeira (e natural) do sexo denominado feminino é a de reproduzir, cuidar e servir os homens, o sexo masculino. Este movimento tem como efeito concomitante a vulnerabilização das meninas em muitos outros aspectos, visto que restringe suas possibilidades de trilhar caminhos emancipatórios em relação as diversas formas de dominação que historicamente incidem sobre seus corpos-vidas.

A própria escola coloca a escolarização em uma posição secundária, menos importante e que, pode ser descartada, em nome da preservação da primeira, a "natural". Ao mesmo tempo, quando as meninas deixam a escola para se dedicarem ao casamento ou à maternidade, são individualmente responsabilizadas por essa "escolha", julgadas e relegadas a própria sorte, sem que a instituição coloque em questão seu papel nesse processo.

De modo geral, os corpos-vidas estudantis que recusam a enquadrar-se nos modelos impostos pela escola são relegados ao que chamamos de 
exclusão/marginalização. Colocando estes/as estudantes no lugar de "impossíveis", daqueles/as que "que não querem nada", "que não tem jeito", a escola assume uma posição omissa e excludente.

Consideramos assim que, por imposição (objetificante) ou omissão (indiferente), antes que a estudante abandone a escola, ela é pela escola abandonada. É neste sentido que adotamos o termo "abandono escolar compulsório". Tal termo visa deflagrar o papel ativo (estrutural) da escola e da sociedade na produção do abandono escolar.

No entanto, acreditamos que as instituições educacionais podem e devem assumir a responsabilidade de romper com as lógicas de dominação. As próprias estudantes consideram que a escola pode ser um espaço potente, o que faz com que muitas retomem os estudos anos depois, na modalidade EJA. De acordo com elas, isso acontece, em geral, depois que os filhos crescem e/ou terminam os relacionamentos em que os parceiros impediam ou não acham importante dar continuidade aos estudos. Mas para que a escola possa de fato operar nessa potência, é imprescindível que seus agentes assumam uma perspectiva crítica em relação às estruturas que fundam essas instituições e trabalhem no sentido de desconstrui-las.

Nesse sentido, para construir estratégias educacionais voltadas à abolição das desigualdades sociais e ao fim das lógicas de dominação, as instituições educacionais e seus/as agentes não podem mais desconsiderar a branquitude e o racismo, na imbricação com o sexismo e a exploração de classe; não podem mais deixar de colocá-las em questão. É preciso descolonizar nossas instituições, nossos olhares, nossos afetos, nossas relações e nossas práticas. Ampliar perspectivas, conhecer e difundir narrativas históricas e sociais construídas a partir de referências contra-hegemônicas.

Como vêm nos apontando as vozes subalternas, é somente a partir dessa mudança de perspectiva, que busca conhecer realmente as condições de existência da população atendida, que poderemos criar efetivamente estratégias educativas coletivas de enfrentamento as lógicas de dominação, capazes de produzir transformação social e política, de construir a educação como prática da liberdade, como nos ensina Freire (2009). Que incluam a todos como sujeitos, isto é, capazes 
de pensar, falar e produzir análises e práticas acerca de suas próprias vidas, comunidades e da sociedade, tendo papel de fundamental importância nessa construção.

Iniciativas nesse sentido vêm acontecendo, dentro e fora da escola, ao longo da história. Sempre houve e haverá resistência. Mas é possível notar que os processos de institucionalização se moldam e encontram novas formas de capturar ou boicotar esses movimentos. Portanto, trata-se de uma luta constante e sempre atenta.

Ouvir de fato as/os estudantes é uma maneira de compreender melhor onde as capturas acontecem, como os discursos e práticas vão sendo atualizados para produzir o mesmo efeito, isto é, perpetuar (atualizando) a mesma lógica opressiva. O diálogo com elas/es é fundamental para que estratégias de fato protetivas sejam construídas. Elas/es não podem estar excluídos desse processo de construção.

No que diz respeito particularmente a Psicologia e às práticas psicológicas, é preciso que estas se desenvolvam a partir de uma compreensão politizada dos sujeitos e das relações que eles estabelecem uns com os outros e com mundo. Não somos seres lançados no vazio. Somos constituídos na história e agimos nas redes de múltiplas e complexas vinculações sociais. As escutas e análises psicológicas precisam se dar a partir desta compreensão. Não podemos mais sustentar práticas de cuidado e acolhimento a partir de perspectivas que objetificam e, assim, silenciam.

Desconstruir a lógica colonial naturalizada em nós e em nossas práticas é fundamental para que avancemos, como sugere Arroyo (2012), na construção de uma epistemologia e ética dos corpos, emancipatória de tantas inferiorizações e ocultamentos. Esta construção só é possível a partir de uma escuta atenta às tantas vozes que compõem nossas histórias, rompendo com estruturas que as organizam em graus de importância verticalizados.

Como nos fala Martín-Baró (2017), para construir novos horizontes é necessário considerar e assumir as perspectivas das maiorias oprimidas. É essa mudança de perspectiva que possibilitará romper com a colonialidade do poder, 
do saber e do ser, permitindo ver outras faces da realidade, assim como criar outras realidades, tão mais múltiplas quanto justas. 


\section{REFERÊNCIAS BIBLIOGRÁFICAS}

ALMEIDA, S. L. O que é racismo estrutural?Belo Horizonte: Letramento, 2018 .

ANZALDÚA, G. Borderland / La frontera: The new Mestiza, San Francisco: AuntLuteBooks, 1987.

ARANTES, E. Proteção integral à criança e ao adolescente: proteção versus autonomia?Psicologia Clínica, Rio de Janeiro, v. 21, n. 2, p. 431450, s/d, 2009: Disponível em: http://pepsic.bvsalud.org/scielo.php?script=sci_arttext\&pid=S010356652009000200012. Acesso em: 05 mai. 2019.

ARROYO, M. G. Corpos-infância precarizados que interrogam nossa ética profissional. In: \& SILVA, M. R. Corpo-Infância. Exercícios tensos de ser criança. Por outras pedagogias dos corpos. Editora Vozes: Petrópolis, 2012, p. 23-54.

ASSIS, W. F. T. Do colonialismo à colonialidade: expropriação territorial na periferia do capitalismo. Caderno CRH, Salvador , v. 27, n. 72, p. 613-627, dez., $2014 . \quad$ Disponível em: http://www.scielo.br/scielo.php?script=sci_arttext\&pid=S010349792014000300011\&lng=en\&nrm=iso Acesso em: 15 mai. 2017.

AULETE, C. Aulete Digital - Dicionário contemporâneo da língua portuguesa. Dicionário Caldas Aulete, versão online. Disponível em: http://www.aulete.com.br/. Acesso em: 12 fev. 2020.

BAREMBLITT, G.Introdução à esquizoanálise. 2. ed. Belo Horizonte: Biblioteca Instituto Félix Guattari, 2002.

HECKET, A. L. C.; BARROS, M. E. B. Fracasso escolar: do que se trata? Psicologia e educação, debates "possíveis". Aletheia 25, Canoas, n. 25, p.109122, jan./jun., $2007 . \quad$ Disponível em: 
http://pepsic.bvsalud.org/scielo.php?script=sci_arttext\&pid=S1413-

03942007000100009 Acesso em: 20 set. 2016.

BEAUVOIR, S. O Segundo Sexo. Tradução Sérgio Milliet. 2. ed. Rio de Janeiro: Nova Fronteira, 2009.

BELTRÃO, K.; TEIXEIRA, M. P. O vermelho e o negro: raça e gênero na universidade brasileira - uma análise da seletividade das carreiras a partir dos censos demográficos de 1960 a 2000. (Texto para Discussão n. 1052). Rio de Janeiro: Ipea, 2004.

BENJAMIN, W. Obras escolhidas. Rua de mão única. São Paulo: Brasiliense, 1987.

BENTO, M. A. S. Branqueamento e branquitude no Brasil. In: CARONE, I.; BENTO, BENTO, M. A. S (Orgs.). Psicologia social do racismo: estudos sobre branquitude e branqueamento. 6. ed. Petrópolis: Vozes, 2014, p. 25-58.

BRASIL. As Desigualdades na Escolarização no Brasil: Relatório de Observação $\mathbf{n}^{\mathbf{0}}$ 5. Brasília: Presidência da República, Conselho de Desenvolvimento Econômico e Social - CDES, 2014.

CANDAU, V. Direitos humanos, educação e interculturalidade: as tensões entre igualdade e diferença. Revista Brasileira de Educação, Rio de Janeiro, v. 13, n. 37, p. 45-56, abr., $2008 . \quad$ Disponível em: http://www.scielo.br/scielo.php?pid=S1413-

24782008000100005\&script=sci_abstract\&tlng=pt. Acesso em: 20 abr. 2016. Diferenças Culturais, cotidiano escolar e práticas pedagógicas. Currículo sem Fronteiras, v. 11, n. 2, p. 240-255, jul./dez., 2011. Disponível em: http://www.curriculosemfronteiras.org/vol11iss2articles/candau.pdf. Acesso em: 15 mar. 2016.

CANDAU, V. M. F; OLIVEIRA, L. F. Pedagogia decolonial e educação antirracista e intercultural no Brasil. Educação em Revista, Belo Horizonte, v. 26, n. 1, p. 15-40, abr., 2010. Disponível em: http://www.scielo.br/scielo.php?script=sci_arttext\&pid=S0102$46982010000100002 \& \operatorname{lng}=$ en\&nrm=iso. Acesso em: 20 out. 2019. 
CARNEIRO, S. Enegrecer o feminismo: a situação da mulher negra na América Latina a partir de uma perspectiva de gênero. Geledés. Instituto da Mulher Negra. São Paulo, 06 mar. 2011. Disponível em: https://www.geledes.org.br/enegrecer-o-feminismo-situacao-da-mulher-negra-naamerica-latina-partir-de-uma-perspectiva-degenero/?gclid=EAIaIQobChMI_nMorqw5wIVTwmRCh0EBQSdEAAYASAAE gJd3_D_BwE. Acesso em: 10 out. 2018.

Escritos de uma vida. São Paulo: Pólen Livros, 2019.

CÉSAIRE, A. Discurso sobre o colonialismo. Lisboa: Sá e Costa Editora, 1978.

COIMBRA, C. M. B. Doutrinas de segurança nacional: banalizando a violência. Psicologia em Estudo, Maringá, v. 5, n. 2, s/d, 2000. Disponível em http://www.scielo.br/scielo.php?script=sci_arttext\&pid=S1413$73722000000200002 \& \operatorname{lng}=$ pt\&nrm=iso. Acesso em: 22 mai. 2018.

COLETIVO COMBAHEE RIVER. Manifesto do Coletivo Combahee River. PLURAL, Revista do Programa de Pós-Graduação em Sociologia da USP, São Paulo, v. 26, n. 1, 2019, p. 197-207, s/d, 2019.

CRENSHAW, K. Whyintersectionalitycan'twait. The Washington Post, 24 set. 2015. Disponível em: https://www.washingtonpost.com/news/intheory/wp/2015/09/24/why-intersectionality-cant-wait/. Acesso em: 12 fev. 2020.

- Documento para o encontro de especialistas em aspectos da discriminação racial relativos ao gênero. Revista Estudos Feministas, Florianópolis, v. 10, n. 1, p. 171, jan., 2002. Disponível em: https://periodicos.ufsc.br/index.php/ref/article/view/S0104-026X2002000100011. Acesso em: 01 fev. 2020. doi:https://doi.org/10.1590/S0104026X2002000100011.

CURIEL, O. Crítica poscolonial desde lasprácticas políticas del feminismo antirracista. Nómadas, Bogotá, n. 26, pp. 92-101, abr., 2007. Disponível em: https://www.redalyc.org/pdf/1051/105115241010.pdf. Acesso em: 20 out. 2019.

Descolonizando el Feminismo: una perspectiva desde America Latina y el Caribe. Anais do Primer ColoquioLatinoamericano sobre Praxis y 
Pensamiento Feminista. Buenos Aires: Grupo Latinoamericano de Estudio, Formación y Acción Feminista (GLEFAS); Instituto Interdisciplinario de Estudios de Género (IIEGE), 2009.

La descolonización desde una propuesta feminista crítica. In: Colección

Feminista Siempre: Descolonización y despatriarcalización de y desde los feminismos de AbyaYala, Tierra del Fogo: ACSUR-Las Segovias, 2015, p. 1122. Disponível em: https://suds.cat/wp-content/uploads/2016/01/Descolonizaciony-despatriarcalizacion.pdf. Acesso em: 07 jan. 2018.

- De las identidades a la imbricación de las opresiones: desde la experiência. In: FLAUZINA, A.; PIRES, T. (Orgs.). Encrespando: Anais do I Seminário Internacional Refletindo a Década Internacional dos Afrodescendentes (ONU 2015-2024). Brasília: Brado Negro, 2016, p. 75-85.

CURIEL, O.; FALQUeT, J. El Patriarcado al Desnudo. Tres feministas materialistas: ColetteGuillaumin - Paola Tabet - Nicole Claude Mathieu. Buenos Aires: Brecha Lesbica, 2005.

DAVIS, A. Mulheres, raça e classe. Tradução de Heci Regina Candiani. São Paulo: Boitempo, 2016.

MAlafaiA, E. AInfluência do Racismo no Processo de Identificação do Negro. Rio de Janeiro, 2019. Dissertação (Mestrado em Relações Étnico-Raciais). Centro Federal de Educação Tecnológica Celso Suckow da Fonseca, CEFET/RJ.

DIAS, F. "Sem querer você mostra o seu preconceito": um estudo sobre as relações raciais entre jovens estudantes de uma escola de Ensino Médio. Belo Horizonte, 2011, 273p. Dissertação (Mestrado em Educação). Faculdade de Educação, Universidade Federal de Minas Gerais, Belo Horizonte, 2011.

DOMINGUES, P. O mito da democracia racial e a mestiçagem no Brasil (18891930). Diálogos Latinoamericanos, Aarhus n. 10, p. 115-131. 2005. Disponível em: https://www.redalyc.org/pdf/162/16201007.pdf acesso em 03-04-2019. Acesso em: 12 fev. 2020. 
FALQUET, J. História do Coletivo Combahee River. Lutas Sociais, São Paulo, v. 22, n. 40, p. 124-137, jan./jun., 2018. Disponível em: https://revistas.pucsp.br/ls/article/view/46660/31123. Acesso em: 12 fev. 2020.

FANON, F. Em Defesa da Revolução Africana. Lisboa: Sá da Costa, 1980.

Pele negra, máscaras brancas. Tradução de Renato da Silveira. Salvador: EDUFBA, 2008.

FARIA, N.; COELHO, S.; MORENO, T. Prostituição: uma abordagem feminista. São Paulo: Sempreviva Organização Feminista, 2013. Disponível em: https://br.boell.org/sites/default/files/prostituicao_uma_abordagem_feminista.pdf. Acesso em: 12 fev. 2020.

FEDERICI, S. Calibã e a bruxa: mulheres, corpo e acumulação primitiva. Tradução Coletivo Sycorax. São Paulo: Elefante, 2017.

O ponto zero da revolução: trabalho doméstico, reprodução e luta feminista. Tradução Coletivo Sycorax. São Paulo: Elefante, 2019.

FOUCAULT, M. Resumos dos do Collège de France (1970-1982). Rio de Janeiro: Jorge Zahar, 1997.

A Verdade e as Formas Jurídicas. Tradução Roberto Machado e Eduardo Morais. 3. ed. Rio de Janeiro: Nau Editora, 2001.

Em defesa da sociedade: curso dado no Collège de France (19751976). Tradução Maria Ermantina Galvão. São Paulo: Martins Fontes, 2005. Sociedade, Território e População. Curso dado no Collège de France (1977-1978). Tradução Eduardo Brandão. São Paulo: Martins Fontes, 2008.

Vigiar e Punir. 36. ed. Petrópolis: Vozes, 2009.

FREIRE, P. Pedagogia do oprimido. 17. ed. Rio de Janeiro: Paz e Terra, 1987. Educação e Mudança. 12. ed. Rio de Janeiro: Paz e Terra, 1979. 
FREYRE, G. Casa grande \& Senzala. Formação da família brasileira sob o regime de economia patriarcal. 14. ed. Rio de Janeiro: José Olympio Editora, 1969.

FRIGOTTO, G. Escola pública na atualidade: lições da história. In: LOMBARDI, J. C.; SAVIANI, D.; NASCIMENTO, M. I. M. (Orgs.). Educação Pública no Brasil: História e Historiografia. Campinas: Autores Associados, 2005, p. 221239.

GALINDO, M. La revolución feminista se llama Despatriarcalización. In: Colección Feminista Siempre: Descolonización y despatriarcalización de y desde los feminismos de AbyaYala, Tierra del Fogo: ACSUR-Las Segovias, 2015, p. 27-50. Disponível em: https://suds.cat/wpcontent/uploads/2016/01/Descolonizacion-y-despatriarcalizacion.pdf. Acesso em: 07 jan. 2018.

GELEDÉS - INSTITUTO DA MULHER NEGRA. Racismo institucional: uma abordagem conceitual. São Paulo: Trama Design, 2016.

GIACOMINI, S. M. Beleza Mulata e Beleza Negra. Revista Estudos Feministas, Rio de Janeiro, v. n./e., p. 217-227, 2. sem., 1994. Disponível em: https://periodicos.ufsc.br/index.php/ref/article/view/16105 Acesso em: 06 jun. 2019.

GILL, A.; PIRES, T. FromBinarytoIntersectionaltoImbricated Approaches: Gender in a DecolonialandDiasporic Perspective. Contexto internacional, Rio de Janeiro , v. 41, n. 2, p. 275-302, ago., 2019. Disponível em: http://www.scielo.br/scielo.php?script=sci_arttext\&pid=S0102-

85292019000200275\&lng=en\&nrm=iso. Acesso em: 04 out. 2019. http://dx.doi.org/10.1590/s0102-8529.2019410200003.1

GOMES, N. L. Trajetórias escolares, corpo negro e cabelo crespo: reprodução de estereótipos ou ressignificação cultural? Revista Brasileira de Educação, Belo Horizonte, n. 21, p. 40-51, set./dez., 2002.

O movimento negro educador: saberes construídos nas lutas por emancipação. Petrópolis: Vozes, 2017. 
GONZALEZ, L. Racismo e sexismo na cultura brasileira. In: SILVA, L. A. et al. Ciências Sociais Hoje, Brasília, ANPOCS, n. 2, p. 223-244, 1984.

GREY,

A.

2015.

You'veheardof

rape

culture,

buthaveyouheardofpedophileculture? FeministCurrent. 21 set. 2015. Disponível em: https://www.feministcurrent.com/2015/09/28/youve-heard-of-rape-culturebut-have-you-heard-of-pedophile-culture/. Acesso em: 12 fev. 2020.

GROSFOGUEL, R. Para descolonizar os estudos de economia política e os estudos pós-coloniais: Transmodernidade, pensamento de fronteira e colonialidade global. Revista Crítica de Ciências Sociais, n. 80, p. 115-147, mar., 2008.

Descolonizar as esquerdas ocidentalizadas: para além das esquerdas eurocêntricas rumo a uma esquerda transmodernadescolonial. Contemporânea Revista de Sociologia da UFSCar, São Carlos, v. 2, n. 2 p. 337-362 Jul./Dez., 2012.

GUZZO, R. Psicologia e Educação no Brasil: uma visão da história e possibilidades nessa relação. Psicologia: Teoria e Pesquisa, Brasília, v. 26, n. spe., $\quad$ p. 131-141, 2010. Disponível em: http://www.scielo.br/scielo.php?script=sci_arttext\&pid=S010237722010000500012. Acesso em: 12 fev. 2020.

HIRATA, H.; KERGOAT, D. Novas configurações da divisão sexual do trabalho. Cadernos de Pesquisa, São Paulo, v. 37, n. 132, p. 595-609, dez., 2007. Disponível em: http://www.scielo.br/scielo.php?script=sci_arttext\&pid=S010015742007000300005\&lng=en\&nrm=iso. Acesso em: 10 fev. 2019.

HOOKS, B. Vivendo de amor. Geledés - Instituto da Mulher Negra. São Paulo, 09 mar. 2010. Disponível em: https://www.geledes.org.br/vivendo-de-amor/. Acesso em: 12 fev. 2020.

Ensinando a transgredir: a educação como prática de liberdade. Tradução Marcelo Brandão Cipolla. São Paulo: Editora WMF Martins Fontes, 2013. 
O feminismo é pra todo mundo: políticas arrebatadoras. 6. ed. Rio de Janeiro: Rosa dos tempos, 2019.

INSTITUTO BRASILEIRO DE GEOGRAFIA E ESTATÍSTICA (IBGE). Pesquisa nacional por amostra de domicílios : síntese de indicadores 2013. 2. ed. Rio de Janeir: IBGE, 2015. Disponível em: https://biblioteca.ibge.gov.br/visualizacao/livros/liv94414.pdf. Acesso em: 12 fev. 2020.

Pesquisa nacional por amostra de domicílios : síntese de indicadores 2015 Rio de Janeiro : IBGE, 2016.

INSTITUTO NACIONAL DE ESTUDOS E PESQUISAS EDUCACIONAIS ANÍSIO TEIXEIRA (INEP). Indicadores de fluxo escolar na Educação Básica. Brasília: 2017. DEED/INEP, Disponível em: http://download.inep.gov.br/educacao_basica/censo_escolar/apresentacao/2017/ap resentacao_indicadores_de_fluxo_escolar_da_educacao_basica.pdf. Acesso em: 12 fev. 2020.

CERQUEIRA, D. et al. (Coord.). Atlas da violência 2018. Rio de Janeiro: IPEA; FBSP, 2018. Disponível em: http://www.ipea.gov.br/portal/images/stories/PDFs/relatorio_institucional/180604 _atlas_da_violencia_2018.pdf. Acesso em: 12 fev. 2020.

JESUS, R. E. Mecanismos eficientes na produção do fracasso escolar de jovens negros: estereótipos, silenciamento e invisibilização. Educação em Revista, Belo Horizonte, v. 34, p. 1-18, jan., $2018 . \quad$ Disponível em: http://www.scielo.br/scielo.php?script=sci_arttext\&pid=S0102$46982018000100102 \& \operatorname{lng}=$ en\&nrm=iso. Acesso em: 25 ago. 2019.

KAFKA, F. A metamorfose. Porto Alegre: Editora L\&PM Pocket, 2001.

KERGOAT, D. Divisão sexual do trabalho e relações sociais do sexo. In: HIRATA, H.; LABORIE, F.; LE DOARÉ, H.; SENOTIER, D. (Orgs.). Dicionário Crítico do Feminismo. São Paulo: Fundação Editora da UNESP (FEU), 2009, p. 67-75. 
KILOMBA, G. Memórias da plantação: episódios de racismo cotidiano. Tradução Jess Oliveira. Rio de Janeiro: Cobogó, 2019.

KRAEMER, H.; SPRENGER, J. O martelo das feiticeiras. Rio de Janeiro: BestBolso, 2015. Disponível em: https://www.armazem3bruxas.com.br/images/ebooks/O-Martelo-das-FeiticeirasHeinrich-Kramer.pdf. Acesso em: 11 ago. 2019.

LANDER, E. A colonialidade do saber: eurocentrismo e ciências sociais. In: (Org.). A colonialidade do saber: eurocentrismo e ciências sociais. Perspectivas latino-americanas. Buenos Aires: CLACSO - Colección Sur Sur, 2005. p. 8-23.

LAURETIS, T. A tecnologia do gênero. In: HOLLANDA, H. B. (Org.). Tendências e impasses: o feminismo como crítica da cultura. Rio de Janeiro: Rocco, 1994. p. 206-242.

LERNER, G. A criação do Patriarcado: história da opressão das mulheres pelos homens. Tradução Luiza Sellera. São Paulo: Cultrix, 2019.

LOURAU, René. Análise institucional e práticas de pesquisa. Rio de Janeiro: Editora UERJ, 1993.

LUGONES, M. Colonialidad y Género. Tabula Rasa, Bogotá, n. 9, p. 73-101, jul./dez., 2008. Disponível em: https://www.revistatabularasa.org/numero9/05lugones.pdf. Acesso em: 12 fev. 2020.

MACHADO, L. A. D. Subjetividades contemporâneas. In BARROS, M. E. B. (Org.). Psicologia: questões contemporâneas. Vitória: EDUFES, 1999, p. 211229.

MALDONADO-TORRES, N. Sobre la colonialidad del ser: contribuciones al desarrollo de un concepto. In: CASTRO-GÓMEZ S.; GROSFOGUEL, R. (Eds.) El giro decolonial. Reflexiones para una diversidad epistémica más allá del capitalismo global. Bogotá: Iesco-Pensar-Siglo del Hombre Editores, 2007, p. 127-167. 
MARTÍN-BARÓ, Ignacio O papel do psicólogo. Estudos de Psicologia, Campinas, v. 2, n. 1, p. 7-27, 1996.

MARTÍN-BARÓ, I. Crítica e libertação na Psicologia. Petrópolis: Editora Vozes, 2017.

MAYORGA, C. et al. As críticas ao gênero e a pluralização do feminismo: colonialismo, racismo e política heterossexual. Revista Estudos Feministas, Florianópolis, v. 21, n. 2, p. 463-484, ago., 2013. Disponível em: http://www.scielo.br/scielo.php?script=sci_arttext\&pid=S0104026X2013000200003\&lng=en\&nrm=iso. Acesso em: 10 fev. 2020. http://dx.doi.org/10.1590/S0104-026X2013000200003.

MIGNOLO, W. Histórias locais/projetos globais: Colonialidade, saberes subalternos e pensamento limiar. Belo Horizonte: Editora UFMG, 2003.

MIÑOSO, Y. E.; CORREAL, D. G.; MUÑOZ, K. O. (Orgs.). Tejiendo de otro modo: Feminismo, epistemología y apuestas descoloniales en AbyaYala. Popayán: Editorial Universidad del Cauca, 2014.

MOORE, C. Racismo e sociedade: novas bases epistemológicas para entender o racismo. Belo Horizonte: Mazza Edições, 2007.

MUNANGA, K. Uma abordagem conceitual das noções de raça, racismo, identidade e etnia. In: Anais do Seminário Nacional Relações Raciais E Educação-Penesb. Rio de Janeiro, 2003. Rio de Janeiro, 2003. Disponível em: http://www.acaoeducativa.org.br/downloads/09abordagem.pdf. Acesso em: 23 jan. 2019.

Rediscutindo a mestiçagem no Brasil: identidade nacional versus identidade negra. Belo Horizonte: Autêntica, 2004.

MURARO, R. M. Introdução. In: KRAEMER, H.; SPRENGER, J. O martelo das feiticeiras. Rio de Janeiro: BestBolso, 2015. Disponível em: https://www.armazem3bruxas.com.br/images/ebooks/O-Martelo-das-FeiticeirasHeinrich-Kramer.pdf. Acesso em: 11 ago. 2019. 
NASCIMENTO, A. Genocídio do negro brasileiro: Processo de um racismo mascarado. Rio de Janeiro: Ed. Paz e Terra, 1978.

NASCIMENTO, M. L. Internação de Jovens pobres: Prática que a travessa história. Em: MENEGAT, M.; NERI, R. (Orgs.). Criminologia e Subjetividade. Rio de Janeiro: Lumen Juris, 2005, p. 149-156.

NOVAES, Willian. Transou com a empregada: por que não se fala de abuso sexual com domésticas. Geledés - Instituto da Mulher Negra. São Paulo,18 jul. 2019. Disponível em: https://www.geledes.org.br/transou-com-a-empregada-porque-nao-se-fala-de-abuso-sexual-com-domesticas/. Acesso em: 12 fev. 2020.

NUNES, A. violência racial e prostituição: Um debate para além o gênero. Anais do $11^{\circ}$ Seminário Internacional Fazendo Gênero 11 \& 13th Women's Worlds Congress. Florianópolis, 2017. Disponível em: http://www.en.wwc2017.eventos.dype.com.br/resources/anais/1499425759_ARQ UIVO_AlyneNunesFG.pdf. Acesso em: 12 fev. 2020.

PALERMO, Z. Colonialidaddel poder y género: una historia local. Sociocriticism, Granada, v. 27, n. 1 e 2, s/d, 2012.

PATTO, M. H. S. O fracasso escolar como objeto de estudo: anotações sobre as características de um discurso. Cadernos de Pesquisa, São Paulo. v. 65, p. 72-77, mai., $1988 . \quad$ Disponível em: http://publicacoes.fcc.org.br/ojs/index.php/cp/article/view/1198/1204. Acesso em: 12 jul. 2017.

PEREIRA, A. A. O movimento negro brasileiro e a lei No 10.639/2003: da criação aos desafios para a implementação. Revista Contemporânea de Educação, Rio de Janeiro, v. 11, n. 22, ago./dez., 2016. Disponível em: https://revistas.ufrj.br/index.php/rce/article/view/3452. Acesso em: 03 abr. 2019.

PFEIL, F. Ouvindo vozes e produzindo rupturas: notas sobre psicologia, justiça e infração juvenil. 2013, 118f. Dissertação (Mestrado em Psicologia Clínica). Departamento de Psicologia, Pontifícia Universidade Católica do Rio de Janeiro.

PORTO-GONÇALVES, C. W. Apresentação da edição em português. In: LANDER, E. (Org.). A colonialidade do saber: eurocentrismo e ciências 
sociais. Perspectivas latino-americanas. Buenos Aires: CLACSO - Colección Sur Sur, 2005, pp. 3-5.

Entre América e Abya Yala - tensões de territorialidades.

Desenvolvimento e Meio Ambiente, Curitiba, n. 20, p. 25-30, jul./dez., 2009.

QUIJANO, A. Colonialidaddel Poder, Cultura y Conocimientoen América Latina. In: Anuário Mariateguiano. Lima, v. 9, n. 9, 1997.

.; WALLERSTEIN, I. Americanity as a conceptortheAmericas in themodern world-system. International Social Science Journal, Paris, n. 134, nov., 1992.

Colonialidad y Modernidad/Racionalidad. PerúIndig. v. 13, n 29, p. 11-

20,1992

RIBEIRO, P. S. Prostituição Infantil: uma violência contra a criança. Brasil Escola. Disponível em: https://brasilescola.uol.com.br/sociologia/prostituicaoinfantil.htm. Acesso em: 29 de abril de 2019.

RIBEIRO, D. O que é lugar de fala? Belo Horizonte: Letramento; Justificando, 2017.

RICH, A. Heterossexualidade compulsória e existência lésbica. Bagoas - Estudos gays: gêneros e sexualidades, Natal, v. 4, n. 05, p. 17-44, nov. 2010.

RIZZINI, I; RIZZINI, I. A institucionalização de crianças no Brasil: percurso histórico e desafios do presente. Rio de Janeiro : Ed. PUC-Rio; São Paulo: Loyola, 2004.

ROMANELLI, O. O. História da educação no Brasil: (1930/1973). 40. ed. Petrópolis: Vozes, 2014.

RUBIN, G. Pensando sobre sexo: notas para uma teoria radical da política da sexualidade. Cadernos Pagu, Campinas, n. 21, p. 1-88, 2003.

SAFFIOTI, H. A mulher na sociedade de classes: mito e realidade. 2. ed. Petrópolis: Vozes, 1976. 
SANTOS, M. Por uma Geografia Nova. São Paulo: Hucitec; Edusp, 1978.

SANTOS, N. S. Tornar-se negro ou as vicissitudes da identidade do negro brasileiro em ascensão social. Rio de Janeiro: Graal, 1983.

SAVIANI, D. Escola e democracia: Polêmicas do nosso tempo. Campinas: Autores Associados, 1999.

SCHUCMAN, L. V. Entre o Encardido, o Branco e o Branquíssimo: Branquitude, Hierarquia e Poder na Cidade de São Paulo. São Paulo: Annablume, 2014.

SCOTT, J. W. Gênero: uma categoria útil de análise histórica. Educação \& Realidade. Porto Alegre, v. 20, n. 2, p. 71-99, jul./dez., 1995.

SEGATO, R. Colonialidad y Patriarcado Moderno: expansión del frente estatal, modernización, y la vida de las mujeres. In: MIÑOSO, Y. E.; CORREAL, D. G.; MUÑOZ, K. O. (Orgs.). Tejiendo de otro modo: Feminismo, epistemología y apuestas descoloniales en AbyaYala. Popayán: Editorial UniversidaddelCauca, 2014, p. 75-90.

SILVESTRINI, D. F. Brasil: o berço do trafico de mulheres e da exploração sexual. Jus, jun. 2014. Disponível em: https://jus.com.br/artigos/29110/brasil-oberco-do-trafico-de-mulheres-e-da-exploracao-sexual. Acesso em: 12 fev. 2020.

SOARES, K.; ZAMORA, M. H. O Brasil e a Lógica Racial: Do branqueamento à produção de subjetividade do racismo. Psicologia Clinica, Rio de Jan2iro, v. 30, n. 2, p. 265-286, 2018. Disponível em: http://pepsic.bvsalud.org/scielo.php?script=sci_abstract\&pid=S010356652018000200005\&lng=pt\&nrm=iso. Acesso em: 05 set. 2019. SPIVAK, G. C. Pode o subalterno falar? Belo Horizonte: Editora UFMG, 1986. SWAIN, T. N. Feminismo radical: muito além de identidades e gênero. eBookKindle. Editora Amazon, 2017.

TAYLOR, A. Y.; LAURO, G.; SEGUNDO, M.; GREENE, M.. "Ela Vai no Meu Barco". Casamento na Infância e Adolescência no Brasil, Resultados de 
Pesquisa de Método Misto. Rio de Janeiro; Washington DC: Instituto Promundo \& Promundo-US, 2015.

UNICEF. Brasil: acesso, permanência, aprendizagem e conclusão da educacão básica na idade certa, direito de todas e de cada uma das crianças e dos adolescentes. Brasília: UNICEF, 2012. Disponível em: https://unesdoc.unesco.org/ark:/48223/pf0000225209. Acesso em: 08 set. 2018.

UNICEF. Cenário da exclusão escolar no Brasil. Brasília: UNICEF, 2017. Disponível em: https://buscaativaescolar.org.br/downloads/guias-emanuais/busca-ativa-escolar-v10-web.pdf. Acesso em 08 set. 2018.

VEIGA-NETO, A.; SARAIVA, K. Educar como arte de governar. Currículo sem Fronteiras,v. 11, n. 1, p. 5-13, 2011. Disponível em: http://www.curriculosemfronteiras.org/vol11 iss1 articles/veiga-neto-saraiva.pdf. Acesso em: 15 abr. 2016.

VILHENA, J. A violência da cor: Sobre racismo, alteridade e intolerância. Revista Psicologia Política, São Paulo, v. 6, n. 12, 2006. Disponível em: http://docente.ifsc.edu.br/leandro.parussolo/MaterialDidatico/Projeto\%20Integrad or\%201\%20-\%20Fase\%201/Artigos\%20\%20Intoler\%C3\%A2ncia\%20Racial/A\%20Viol\%C3\%AAncia\%20da\%20Cor\%2 0-\%20sobre\%20racismo,\%20alteridade\%20e\%20intoler\%C3\%A2ncia.pdf. Acesso em: 12 fev. 2020.

WAISELFISZ, J. J. Mapa da Violência 2012: Os Novos Padrões da Violência Homicida no Brasil. São Paulo: Instituto Sangari, 2011. Disponível em: https://www.mapadaviolencia.org.br/pdf2012/mapa2012_web.pdf. Acesso em: 07 jun. 2017.

Mapa da Violência 2015: homicídio de mulheres no Brasil. Brasília:

Editora ONU Mulheres, SPM, Flacso, 2015. Disponível em: http://www.mapadaviolencia.org.br/pdf2015/MapaViolencia_2015_mulheres.pdf. . Acesso em: 07 jun. 2017.

WALSH, C. Interculturalidade crítica e pedagogia decolonial: in-surgir, re-existir e re-viver. In: CANDAU, V. (Org.). Educação intercultural na América 
Latina: entre concepções, tensões e propostas. Rio de Janeiro: 7 Letras, 2009. p. $12-42$.

WITTIG, M. The categoryof sex. In: __ The straightmindandotheressays. New York: Beacon Press, 1992, p. 1-8.

ZAMORA, M. H. Desigualdade racial, racismo e seus efeitos. Fractal: Revista de Psicologia,Rio de Janeiro, v. 24, n. 3, p. 563-578, set./dez., 2012. Disponível em: http://www.scielo.br/scielo.php?script=sci_arttext\&pid=S198402922012000300009\&lng=en\&nrm=iso. Acesso em: 07 out. 2016. 